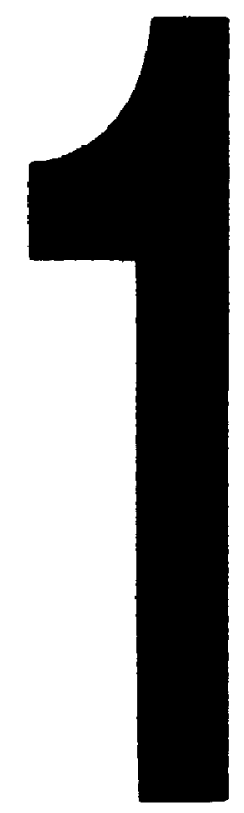

.9
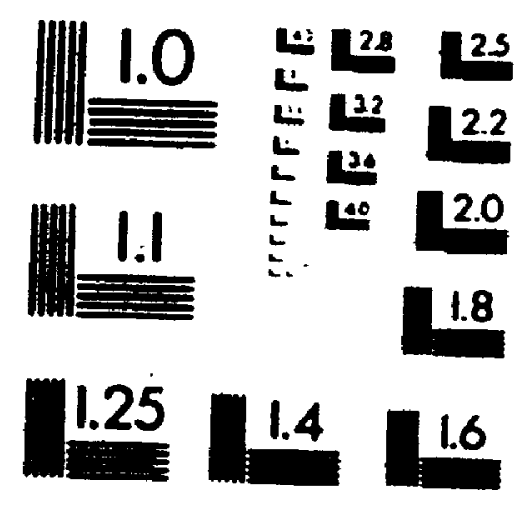

.0
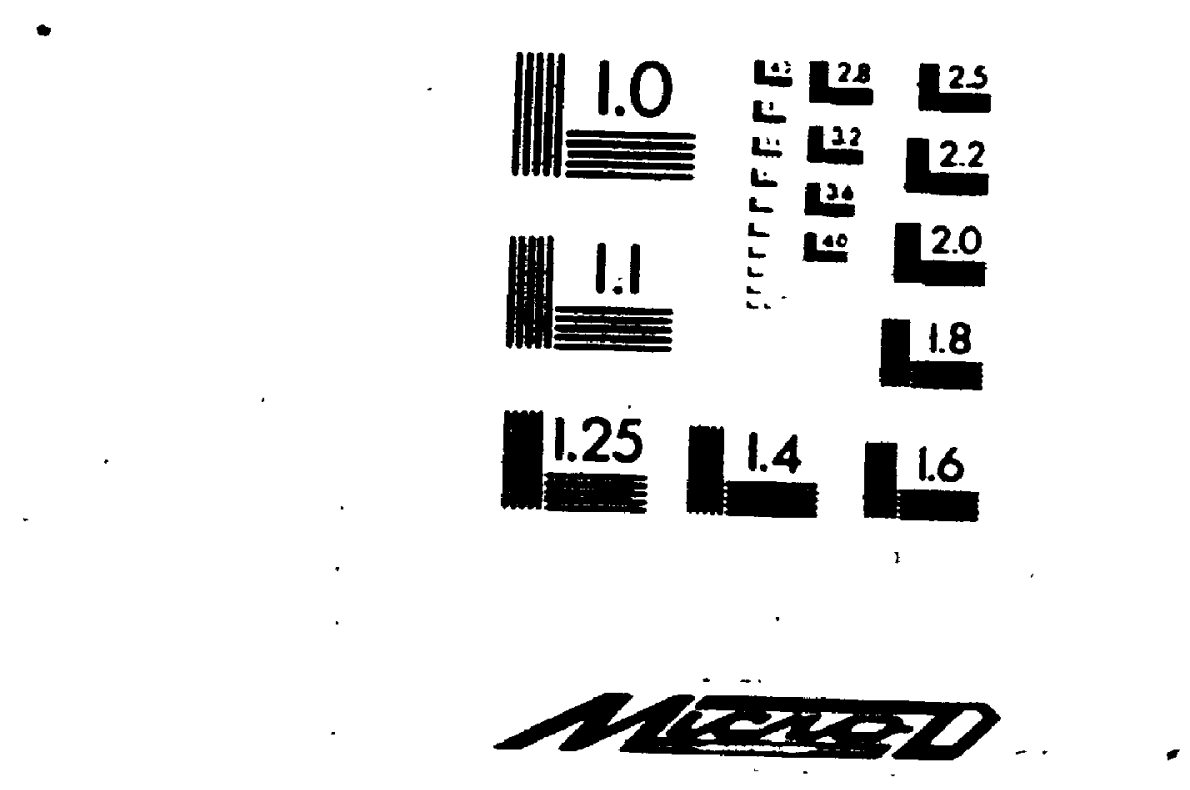

s. 
Notone Librery

al Ceneda

Canedien Theses Service

Onerme, Cenede

K1A ONA
Bullothique netionale du Consda

Services des theses canadiennes

\section{CANADIAN THESES}

\section{NOTICE}

The quallty of this microfiche is heavily dependent upon the quality of the original thesis submitted for microfitming Every effor fles been made to ensure the highest quality of reproduction possitie.

If phos are missing. contact the university which granted the degree

Some pages may have indistinct print especially if the original peges were typed with a poor typowriter ribbon or if the university sent us an inferior pholocopy

Previously copyrighted materials (journal articles. published tests. etc.) are viot filmed

Reproduction in full or in part of this film is governed by the Canedien Copyright ACt. A S.C. 1970. C C-30

\section{THĖSES CANADIENNES}

THIS DISSERTATION HAS BEEX VICROFILMED EXACTLY AS RECEIVED
La qualite de cette microfiche depend grandement de la qualite de la these soumise au microhimage Nous avons loul tail pour assurer une qualite superieure de reproduction S'il manque des pages, veuillez communiquer avec l'univer. silé qui a contere le grade

La qualité d'impression de certaines pages peut laisser a desirer. surtoul si les pages originales ont ele dactylographibes a larde ofun ruban use ou si liuniversite nous a lail parveni une pholocopie de qualite interieure

Les documents qui tont depel l'objet d'un dront d'auleur (articles de revue. examens publies. elc ) ne sont pas miciolilmos

La reproduction, meme partielle. de ce microfilm est soumise a la Lor canadienne sur le drorl d'auteur. SRC 1970, c C.30

\section{LA THESSE A ETE MICROFILMÉE TELLE QUE NOUS. L'AVONS RECUE}


GEOLOGY AND GEOCHEMISTRY OF TALC DEPOSITS

IN THE MADOC AREA, ONTARIO

$$
\text { by }
$$

(r) GEORGE J. SIMANDL

B.Se. (Spec. Geot.), Concordia University, 1978

\section{A thesis submitted to}

the Faculty of Graduate Studies and Research

in partial fulfilment of the requirements

for the degree of

Master of Science

Department of Geology

Carleton University

Ottawa, Ontario

November,

$$
1984
$$

Copyright 1984 
Permission has been granted to the National Library of canada to microfilm this thesis and to lend or sell copies of the film.

The author (copyright owner) has reserved other publication rights, and neither the thesis nor extensive extracts from it may be printed or otherwise reproduced without his/her written permission.
L'autorisation a été accordée à la Bibliothèque nationale du Canada de microfiliner cette thèse et de prêter ou de vendre des exemplaires du film.

Lauteur (titulaire du droit d'auteur) se réserve les autres droits de publication; ni la thèse ni de longs extraits de celle-ci ne doivent êtré imprimés ou autrement reproduits sans son autorisation écrite. 


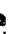

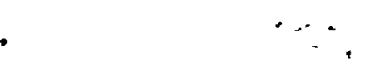

The undesigned hereby recorder to the Faculty of Graduate Studies and Pesearchiccertance of this thesis, submitted by George J. Simandl, E.Sc., in partial fulfilinent of the requirements for the degree of Master of Science.

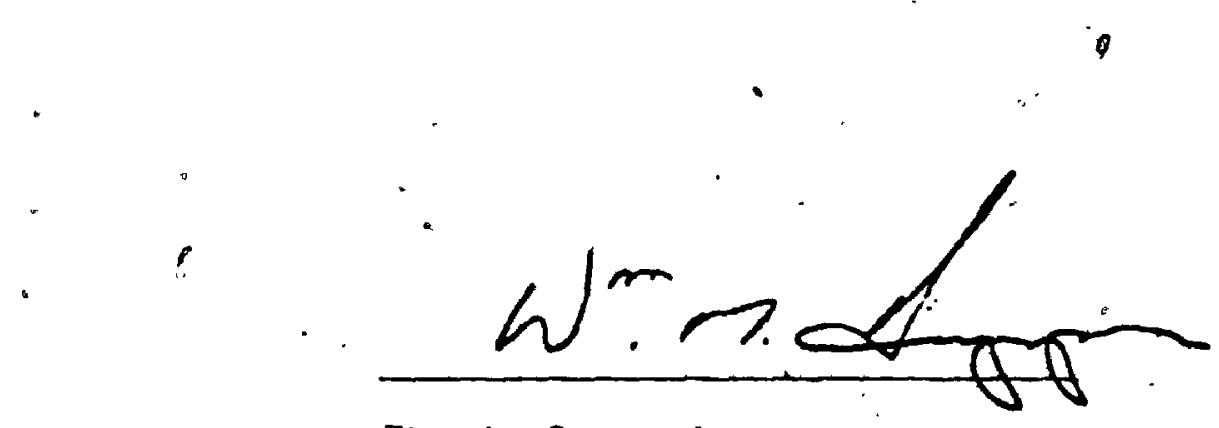

Thesis Supervisor

6

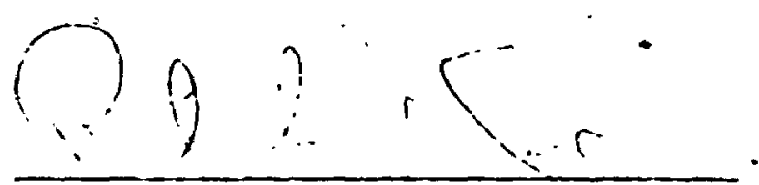

Chairman, Department. of Geology

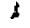




\section{ABSTRACT}

- The Henderson talc deposit is located within Hastings metamorphic "low". It is one of the widest known sections of a main talc horizon, which is hosted by tremolitic, micaceous, dolomitic marble belonging to the Grenville Supergroup. It is a deformed tabular body over $250 \mathrm{~m}$ long, 7 to $25 \mathrm{~m}$ thick, at. least $250 \mathrm{~m}$ deep, opqn at depth, striking $42^{\circ}$ and dipping $65^{\circ}$ to $85^{\circ} \mathrm{NW}$. Talc, ore is unusually'white. Brightness of dry ore milled to -325 mesh is 95 to. 96 on the 100 unit scale under green filter, making the ore suitable for a wide variety of industrial applications.

The ore consists mainly of talc (over 70x), dolomite (24\%), serpentine (2 to $3 x$ ) phlogopite (2x) and tremolite (less than 18). The core of the deporsit. is coarse grained, richer in talc and it has a higher $\mathrm{MgO} / \mathrm{CaO}$ ratio than peripheral fine-graíned ore.

The Henderson deposit was traditionally regarded as a vein type deposit; however, structural stratigraphic, petrological, mineralogical and geochemical investigation in conjunction with known regional tectonic history indicate that at least, a portion of the ore could have been either precipitated on the sea-floor or derived by diagenesis and/or low grade. metamorphism from magnesium rich sediments. Unusually high talc content and high MgO/CaO ratio and absence of calcite within the ore exclude the possibility that "Normal" prograde ragional metamorphism of siliceous dolestone was the sole talc-forming process involved in the formation. of the deposit.. 


\section{Acknowledgements}

Dr. M. Klugman, Mine-Coordinator (O.D.M.) suggested the project, undertagk the latitial contact with Canada Talc Ltd. and oncouraged me in the eadly part of the study. Mr. P. Barnes, President and owner of Canada Talc-Industries hired me as a geologist on a part-time basis.

Mr. D: G. Ogden, consultant and owner of Vermont Stone and Minerals Ltd., and Drs. D. H. Watkinson and J.M. Moore from Cageton University, motivated me by enriching discusstons in hours of desplir, although they were not part of my thesis committee at that time:

Reviews of the manuscript by Drs. D.H. Watkinson and J.M. Moore are greatiy apprectated. Dr. W.M. Tupper contributed extensively to the (jmprovement of no writing skills in mo fourth language durting the last

two and a half years.

Drafting equipment and supplies, photographic supplies, development of films, thin sections, polished sactions and chemical analysis; typing and travel expenses between Madoc, Ottawa and Montreal were financed by my iffe Suzanne and myself. 
Page

Abstract

Acknowl edgements

Table of Contents

i11

List of Tables

vi

Loist of Figures

vit

List of Plates

CHAPTER 1: INTRODUCTION

i.l Background

1.2 Location and access

1.3 Objectives of this sturay

1.4 Methods

1.5 Previous Work

I.6 Hfstory

CHAPTER 2 - REGIONAL GEOLOGY

2.1 Geology of the Hastings Region

2.2 Stratigraphy and ithology

2.3 Structural geology

2.3.1 Folding

2.3.2 Faults

2.4. Tectonic H'story

2.5 Metamorphism

...

CHAPTER 3: GEOLOGY OF THE MADOC AREA 16

3.1 Lithology

3.2 Structural geology

3.3 Metamorphism

a 3.4 Mineral deposits

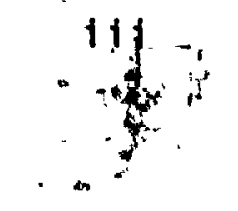


CHAPTER 4:. GEOLOGY OF THE HENDERSON MINE AREA 21

4.1 Stratigraphy 21

4.2. Lithology 24

4.2.1 Metavolcanics and metasediments of-volcanic origin 24

4.2.2 Metapelites

4.2.3 Feldspathic porphyry 27

4.2.4 "Phyllite" " 29

4.2.5 Tremolitic," micaceous marble (Footwall) 30

4.2.6 Talc horizon 33

4.2.7 Laminated micaceous tremolitic marble (hanging wall) 33

4.2.8 "Mottled-blue" Marble

4.2.9 Quartzite with Stromatolitic Texture 37

4.2.10 Moira Lake granite 39

4.2.11 Fracture. Fillings of the Henderson Map Area .. 40

4.2.12 Paleozotc rocks 45

4.2.13 Pleistocene deposits 48

4.3 Structural Geology 48

4.3.1 Folding : 48

4.3.2 Faulting : 49

4.3.3 Structural control of talc deposits

CHAPTER 5: HENDERSON AND RELATED TALC DEPOSITS *

5.1 Henderson Deposit . . 53

5.1 .1 Morphology and structure $\quad . \quad 54$

5.1 .2 Lithology.

5.1 .3 Characteristics of talc product $\quad 58$

5.2 Conley Deposit 58

5.2.1 Morphology and structure $\quad 63$

5.2.2 Talc-bearing rocks . 63

5.3 East-deposit $\quad 63$

5.3.1 Morphológy : : $\quad .64$

5.3.2 Talc ore : $\quad 64$

-5.4 A brief note on New Conley Deposit , . . 64

CHAPTER 6: GEOCHEMISTRY OF THE ROCKS FROM HENDERSON AND
NEW CONLEY DEPOSITS

6.1 Description of samples from Henderson and New Conley
deposits

6.2 Chemical composition of Henderson deposit and its host rock

$6.3 \mathrm{MgO} / \mathrm{CaO}$ ratio

$6.4 \mathrm{SiO}_{2}-\mathrm{CaO}$ - MgO diagram

$\therefore 6.5$ Chemical zoning across the Henderson deposit*

6.6 Chemistry of talc ore and host rock from Henderson deposit versus other talc occurrences in carbonate rocks 74 in North America

6.7 Henderson deposit compared with other-talc occurrences in carbonate rocks in North America. 

Table 1: Table of Formations for the Grenville Supergroup and Flinton Group in the Hasting region (Moore \& Thompson 1980).

Table 2: Partial chemical analysis of the light and dark grey phases of the "Mottled blue" marble.

Table 3: Chemical analysis of the rocks from Henderson and New Conley deposits.

Table 4: Quantitative estimated by SEM/EDXA on the average mill run from Henderson deposit:

Table 5: Typical chemical analysis of the average mill run from Henderson deposit.

Table 6: Average physical characteristics of the coarse, flaky talc-bearing rock and steatite mixture (mill run) 60 from Henderson deposit.

Table 7: Quantitative estimate of mineral compositons by SEM'EDXA on New Conley talc ore.

Table 8: Typical chemical analysis of Nem Conley ore.

Table 9: Geochemistry of major rock types (Henderson deposit).

Table $10 ; \mathrm{MgO} / \mathrm{CaO}$ ratios of samples from Henderson deposit.

Table 11: Mg0/CaO ratios of samples from New Conley (341 foot level) drift.

Table 12: Chemistry of talc ores.from Henderson and Conley deposits.76

Table 13: Metamorphic reactions in silliceous dolostone.

Table 14: Key reactions in the system $\mathrm{MgO}-\mathrm{SiO}_{2}-\mathrm{H}_{2} \mathrm{O}-\mathrm{CO}_{2}$ system.

Table 15: Key reactions in the $\mathrm{MgO}-\mathrm{SHO}_{2}-\mathrm{H}_{2} \mathrm{O}-\mathrm{CO}_{2}$ system.

Table 16: Origin of the Henderson talc deposit.

Table 17: Thirty-five criteria in relation with models described in Chapter 7.

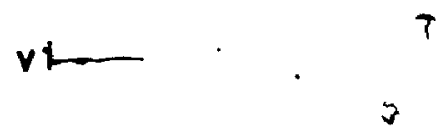




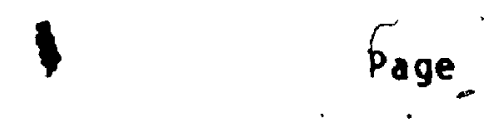

Figure 1. Location of the talc deposits, Madoc, Ontario. 2

Figure. 2. Henderson orebody and neighbouring talc dofposits. 5

Figure 3. Tectonif setting of the Hastings regton. 8

Figure 4. Metamorphic isograds in Hastings regtón.. 15

Figure 5. Lithology of the Madoc area, simplified map from (Hewitt 1968).

Figure 6. Geology of the Henderson mine area. (Back pocket)

Figure 7. Stratotype section of Henderson, mine area.

figure 8. Geology of the Henderson mine (541.65 foot level). (Back pocket).

Figure 9. Coarse calcite-phlogopite-quartz-sulphide vein cutting fine grained, pyrite-bearing dyke of siliceous appearance.

Figure 10. The homogeneity test of deformation in Henderson mine area.

Figure 11. Geological map of the decline. (Back pocket)

Figure 12. Structural control and talc-bearing zones in Henderson mine area.

Figure 13. Typical vertacal section through Henderson deposit. 55

Figure 14. 'Conley deposit, underground workings. 61

Figure 15. Typical cross section of the East deposit. 62

Figure 16. Localities of samples submittẹd for chemical analysis.

Figure 17. Linear relationshio between $\mathrm{MgO}$ and $\mathrm{CaO}$ content in selected hand speciméns from the Henderson deposit. 71

Figure 18. $\mathrm{SiO}_{2}-\mathrm{CaO}-\mathrm{MgO}$ diagram. 
Page

Figure 19. Variation in major elements aross the Henderson deposit

Figure 20. Henderson deposit compared with-other occurrences of talc in carbonate rocks.

Figure 21. Solubility relations of magnesian silicates in aqueous solutions.

Figure 22. Geology of the Trimouns deposit.

Figure 23. Isobaric $X_{c 02}$ diagram at $5 \mathrm{~Kb}$ fluid pressure for reactions in silliceous dolostone.

Figure 24. Isobaric equtlibrium curves in the system $\mathrm{MgO}-\mathrm{SiO}_{2}-\mathrm{H}_{2} \mathrm{O}-\mathrm{CO}_{2}$ system.

Figure 25. Isobaric equilibrium curves of selected reactions in the. Iow $x_{\mathrm{CO}}$ range of the $\mathrm{MgO}-\mathrm{SiO}_{2}-\mathrm{H}_{2} \mathrm{O}-\mathrm{CO}_{2}$ system.

Figure 26. Isobaric equilibrium curves of reactions occurring at large $\mathrm{X}_{\mathrm{CO}}{ }^{2}$ values in $\mathrm{MgO}-\mathrm{SHO}_{2}-\mathrm{H}_{2} \mathrm{O}-\mathrm{CO}_{2}$ system.

Ftgure 27. Relative chronology in the Henderson mine area and its relation to Grenvillian orogenic cycle.

Figure 28. Logarithmic activity diagrams for the system. $\mathrm{CaO}-\mathrm{SiO}_{2}-\mathrm{MgO}-\mathrm{H}_{2} \mathrm{O}$ at $425^{\circ} \mathrm{C}, 0.5 \mathrm{~Kb}$ and $\mathrm{aH}_{2} \mathrm{O}=1$. 


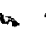

\section{LIST OF PLATES}

Plate 1: Inter-metasediments of volcanic origin and metavolcanics

Plate 2: Metapelite

Plage 3: Laminated "phyllite"

Plate 4: Coarse, flaky, white talc-bearing rock

Plate 5: Coarse, flaky; white talc-bearing rock

Plate 6: Steatite

Plate 7: Steatite

Plate 8: Laminated micaceous tremolitic marble, hanging wall

Plate 9: Quartzite with stromatolitic textures 
CHAPTER I: INTRODUCTION

\subsection{Background}

$\because$ Talc occurs in a variety of geological entiranments, but most talc déposits occur efther in altered ultramafic and mafic rocks, or in : dolonitic marbiles.

The Henderson. Conley and East deposits, located near Madoc, in eastern Ontario, belong to the second category. These deposits are unique in Canada because of their large size, chemical and mineralogical uniformity, high talc tenor, association with maeble, and stratabound nature. The geology of the Henderson deposit has been subjected to several studies, but because of its complexity, has not been well understood.

\subsection{Location and accoss}

The Henderson, Conley and East deposits are located about $1 \mathrm{~km}$ southeast of the Village of Madoc, on lots 14 and 15, concession XIV of Huntingdon Township in the Hastings County. The village of Madoc is about halfway between ottawa and Toronto; at the intersection of highways No. 62 and No. 7 (Fig. 1):

\subsection{Objectires of this study}

The objectives have been to:

1) map the geology of the surface and accessible underground levels:

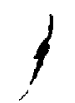

2) Describe the geology of talc deposits and theic host rocks; 


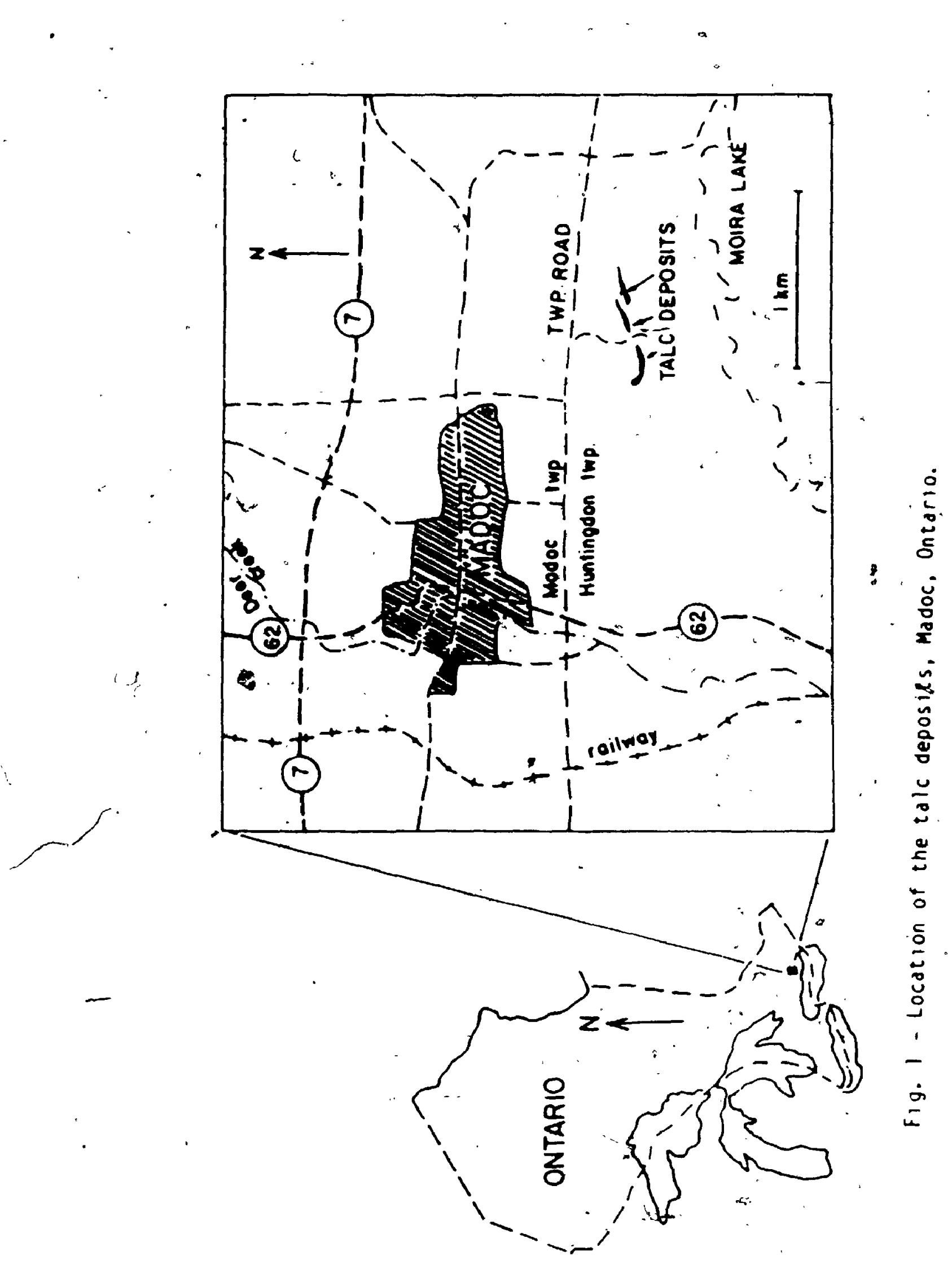


3). establish the morphology of the deposits;

4) determine the mineralogy and chemital composition of the talc deposits and their host rocks;

5) determine the structural history of the talc horizon(s) and enclosing rocks;

6) establish, to the extent possible, the genesis of the talc deposits.

The results of this work should be useful in delineating extensions of the known talc deposits and in finding new ones.

\subsection{Methods}

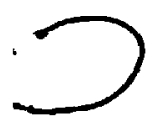

The surface area around the Henderson mine and related deposits was mapped at the scale of $1: 1200$. Two underground levels in the Henderson mine were mapped at the scale of $1: 360$. Core from 1981 and 1982 drilling programs was logged. Cross sections of the Heńderson and East depusits were produced at the scale of $1: 360$.

Representative samples of the talc deposit and enclosing rocks were collectéd and the mineralogy and textural relations examined in thin section. Results, where necessary, were confirmed by x-ray diffraction, and qualitative microprobe analysis. Subsequently ten samples were selected for chemical analysis of the major elements. The detailed field and laboratory methods are described in Appendix 1 .

$\therefore \quad 1.5$ Previous Hork

The Henderson deposit and its immediate surroundings have been subjected to numerous geological investigations "Miller and Knnight ig13, : 
Sṕence 1922, Wilson 1926, Osborne 1931, Sandomirsky 1954, Hewitt 1957 and Roscoe 1966).

Sandomirsky (1954) reviewed the history of the Henderson mine, the production data, and existing hypotheses relating to the formation of. the Henderson deposit. He relied in part on geological maps produced by Wilson (1926) and Spence (1922) and concentrated his efforts on the petrography and mineralogy of the Henderson deposit.

Roscoe (1966) mapped a portion of the 541 foot level of the Henderson deposit and concentrated on the structural geology of the talc deposit and enclosing rocks. No known geological work has bęen carried out on the Henderson or Conley deposit in the last fifteen years:

\subsection{History.}

The discovery of the Henderson talc deposit in Huntingdon Township near Madoc occurred in 1893 (Dickson 1981). It was discovered by Alexander Henderson while ploughing a field. Three years later the first small scale explottation took place and the operation grew rapidly. The original discovery is now the Henderson orebody (Fig. 2 ). Production from the Henderson deposit has been continuous since 1896 .

The deposit was first mined by open pit and later as an underground mine, It is ñow being mined at a depth of more than 220 metres. The Contey deposit, an extension of the Henderson deposit was discovered in 1911 (Dickson 1981). It was mined out in 1943. The ownership of Henderson and Conley properties changed hands several times prior to - 1937. when both were uaited-under a company known as the Canada Talc Ltd. (Sandomfrsky 1954). Canada Talc Ltd. was acquired by Canada Talc 

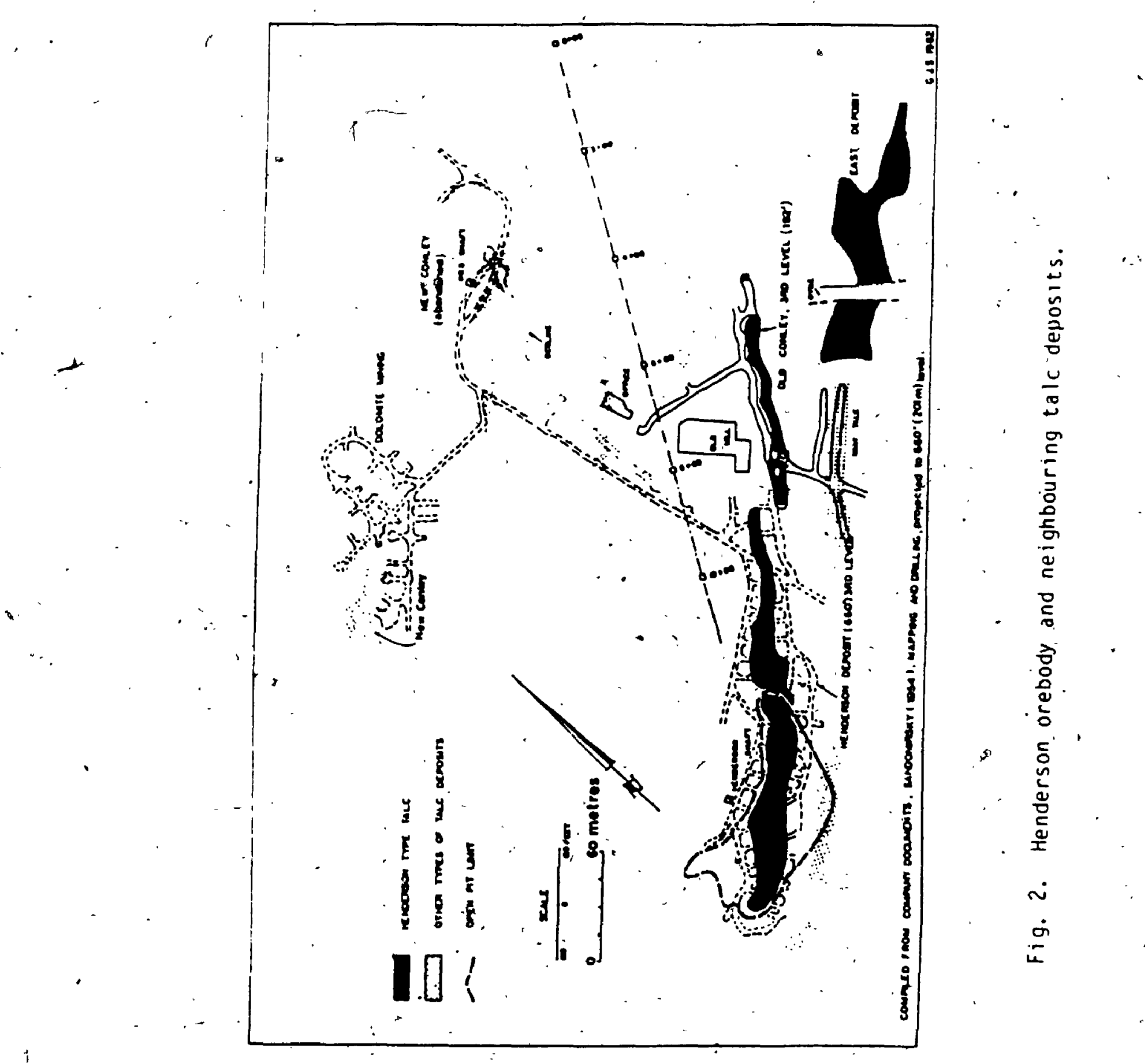

. 
Industries Ltd. in 1951 (Sandomirsky 1954). William R. Barnes Co. Ltd. took control of Canada Talc Industries Ltd. In May 1981.

Canada Talc Industries, based in part on the information obtained in the early part of this study, undertook an extensive diamond drilling program in 1981. The "East" talc deposit was discovered during this drilling program. This deposit is now being preparedifor production. 
CHAPTER 2 - REGIONAL GEOLOGY

\subsection{Geology of the Hastings Region}

The talc deposits of the Madoc area are in the Hastings "Basin",

(Fig. 3) which forms part of the Central Metasedimentary Belt of the

Grenville Province (Wynthe-Edwards 1972). The Hastings region is underlain by late Precambrian metavolcanics and metasediments* of the Grenville Supergroup añd cut by intrusive mafic to felsic rocks.

\subsection{Stratigraphy and lithology}

The stratigraphy of the Grenville Supergroup in the Hastings region is complex because of abundant lateral lithological variations (Lumbers 1967, Moore and Thompson 1980). The Grenville Supergroup is subdivided: into the Hermon and Mayo Groups (Lumbers 1967, Wynne-Edwards 1972, Moore and Thompson 1972, Moore and Thompson. 1980). The stratigraphy. of an. area northeast/yof Madoc has been interpreted by Moore and Thompson (1980) as shown in Table 1. A minor unconformity separates the Hermon Group from the Mayo Group. The stratigraphic thickness of the preserved rocks of the Hermon and Mayo Groups was estinfied at 8300 metres (Wynne-Edwards 1972).

The Flinton Group overlies the Mayo and Hermon Groups. The base of the Flinton Group is marked by a heterogeneous assemblage of conglomerate and/or black pelftic schist, which are separated from the rest of the Flinton Group by. minor unconformity (Moore and Thompson 1980).

* The numbers that decompant individual Hithological descriptions refer, to the various units in Table 1. 


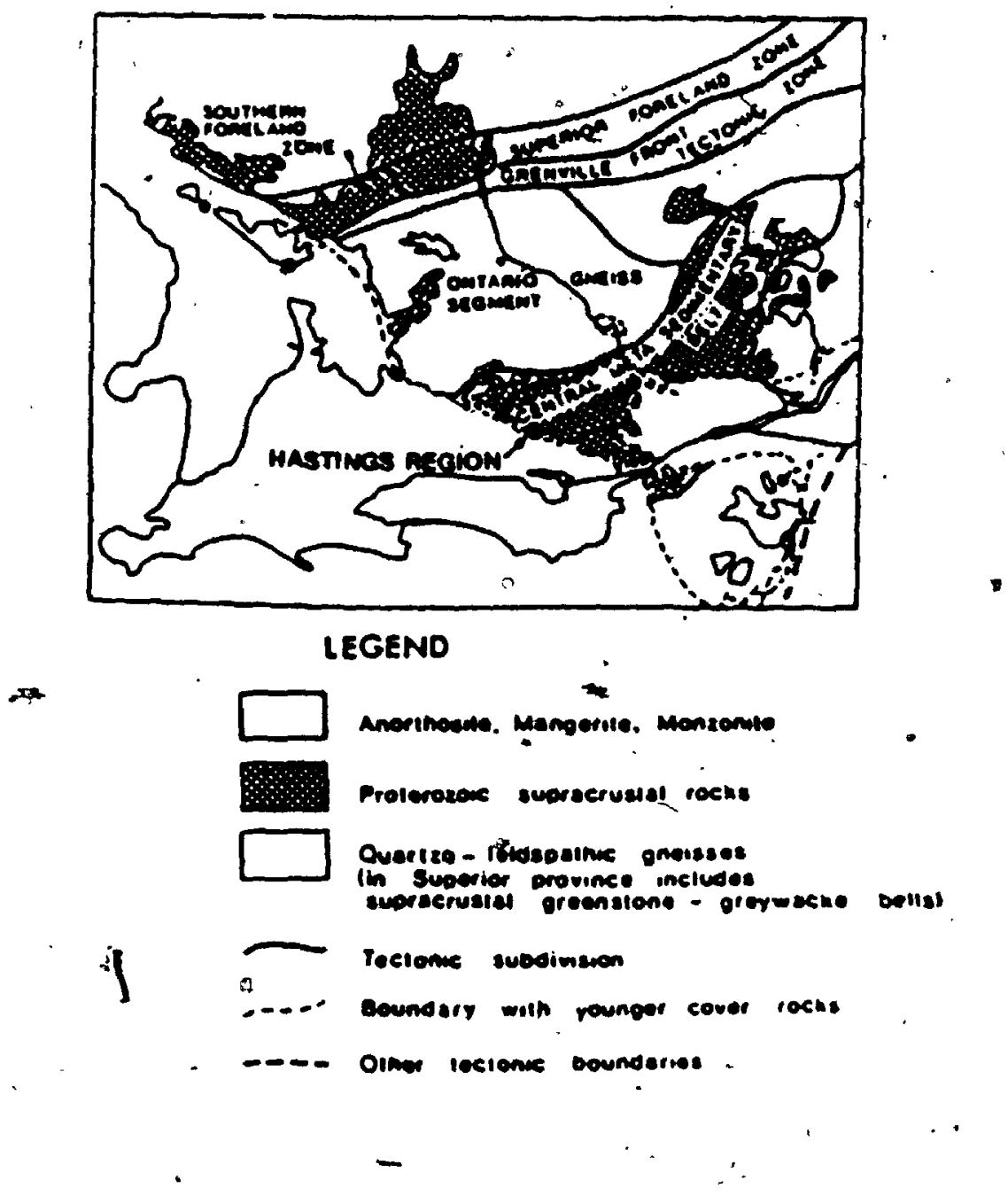

Fig. 3 - Tectonic setting of the Hastings region (modified from Wynne-Edwards 1972). 
TABLE 1. Table of Formations for the Grenville Supergroup and Flinton Group in the Hastings region (Moore and Thompson 1980)

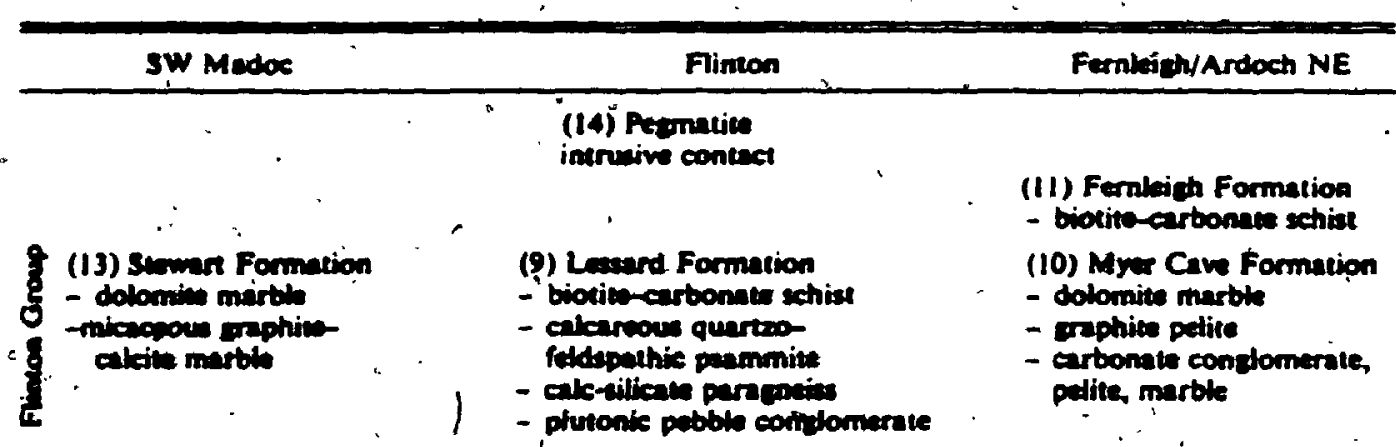

(12) Modoc Formation - patitic schios (b) Bishop Corners Formation

- pelitic schies

- quartrite conclomernte

- quartzite quarto-foldepathic pasmmile

- whise quartitu conglomerete

minor unconformity

(6) Skocenonaten formation

- volocanic pebtele condomento

- carbocale pubble condomerate

- - calcancos phyllite, puemmite

mujor unconformity.

(3) Futonic rocks

Sa hornblend-biotite cranodiorite

Sb biotite granite

intrusive contect

(7) Ore Chimnoy Formation

- ermet-biotite sehist

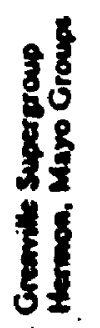

(2) Voteanic rocks

2a tholeiine baselk (Tudor (m.)

(4) Marble

26 playjoctenorich baself.

beablite andmite

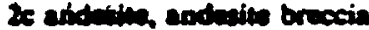

$2 d$ dreithe, myolis

(1) Moke, ultomale intrusw rocks

Is uterparise rocts

Ib Kaftitar malic complex

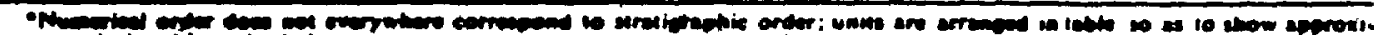

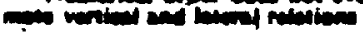


Abundant lateral lithological changes exist within the filnton Group. (Table 1). These change are caused by lateral vartations in the depositional environment and by variations in the lithology of the older, pre-flinton source rocks (Moore and Thompson 1980).

Granitoid plutons are known to intrude part of the Grenville Supergroup but predate the Flinton Group (Moore and Thompson 1980. Lumbers 1967, Davidson et ai. 1979).

Only late pegmatites penetrate the Filinton Group (Moore and Thomp son 1980).

In the southern part of the Hastings region, all the rocks described above are unconformably overlain by Paleozalc arkosic and carbonate rocks. Unconsolidated Pleistocene sediments unconformably overlie both Precambrian and Paleozolc rocks.

\subsection{Structural geology}

Rocks of the Precambrian age sere strongly affected by faulting and polyphase folding, to produce a prominent northeasterly structural grain.

\subsubsection{Folding}

The folds in the area are characterized by axial plane schistosity (Wynne-Edwards 1972). Parts of the grenville Supergroup show interference patterns (fincluding large changes in orientation and in plunge of the lineations) caused by interference of at least two major fold sets (Wynne-Edwards 1972). 
Three types of folds were recognized in rocks of the Flinton Group by Thompson (1972). They are:

1. isoclinal folds with variable plunge parallel to regional strike, usually tens of kllometres in length $\left(0_{1}\right)$;

11. folds formed by deformation about axtal surfaces with northeastern trend $\left(D_{2}\right)$;

ifi. open folds with northwest trending axial surfaces $\left(D_{3}\right)$. Isoclinal folds are probably responstble for a lithological pattern described by Lumbers (1967) as narrow synclinorial marble belts between the anticlinoral belts of metavolcanics and non-carbonate metasediments and dome shaped plutonic intrusions.

\subsubsection{Faults}

Faults of the Madoc-Bancroft region can be subdivided into north to east-northeast faults and west-northwest faults-(tumbers 1967). The style of faulting is not well known; however, at least some of the faults of the west-northwest system are normal (Lumbers 1967), possibly related to the faults of Ottawa-Bonnechere system (Kay 1942, Hewitt 1964). "Northwest trending, post-Ordovician faults which control" barite-fluorite mineralization in the Madoc area are probably strike slip faults (based on a.study of slickensides and striations by Wilson $(1929)$.

\subsection{Tectonic History}

The regional tectontc history described below is based on the work of Moore and Thompson (1980). The probable Aphebian crystalline 
- -

basement to the Grenville Supergroup comprises complex migmatites and gneisses. These rocks were dated by Krogh and Davis (1968), and Baer (1976) at or more more than 1500 Ma and by Bell and 81 enkinsop (1980) at $1430 \pm 20 \mathrm{Ma}$. These dates correspond probably to a metamorphic event (Bell and Blenkinsop 1980).

The consolidation of the basement was followed by the deposition of the Grenville Supergroup, exposed to the northwest of, the study area between 1300 and $1225 \mathrm{Ma}$ (Moore and Thompson 1980). The oldest known rocks of the Grenville Supergroup are the mafic (Tudor) volcanics* (2d, Table 1) of the Hermon Group. They have an age of $1286 \pm 15$ Ma based on PD-U dating of zircons (Silver and Lumbers 1966)**. This age was confirmed by the Rb-Sr method (Bell and Blenkinsop '1980).

The ages of the intrusive rocks (5, Table 1) of the Hastings Basin L were investigated by Silver and Lumbers (IgאK). They recognized at least two periods of magmatic activity: an early period at about $1266 \mathrm{Ma}$ and a younger period about $1104 \mathrm{Ma}$. Bell and Blenkinsop (1980): confirmed approximately these dates by determining that a major period of plutonic activity, metamorphism and geformation (Elzevirian orogeny) $* \star$ took place between 1250 to $1100 \mathrm{Ma} .{ }^{87} \mathrm{Sr} / 86 \mathrm{Sr}$ ratios indicatê a cogenetic relationship between the eạlier magmatic phase and Tudor volcanics (Bell and Blenkinsop 1980).

* Prefix meta is not used in the sections describing regional geology and the geology of the Madoc ared to keep in line with references and figures borrowed from the references.

* Recalculated by Bell and Blenkinsop

$\star \star \star$ Teim proposed by A. Baer for early phase of "Grenvillian orogeny" (Moore and Thompison 1980). 
Uplift, erosion and deposition of the Flinton Group was estimated at $1065 \pm 25 \mathrm{Ma}$ (Moore and Thompson 1980). The conglomerate at the base $f$ of the Finton Group has a maximum age of $1118 \pm 30$ Ma obtained by U-Pb method (Davidson et al. 1979). The major period of polyphase deformation and reglonal metamorphism (Ot tawan Orogeny) took place between $1050-1000 \mathrm{Ma}$.

Two recent models have been proposed for the evolution of the Grenville Province. An aulocogen model was presented by Baer (1976). Subduction followed by continental collision was proposed by Brown et a). (1975). Evidence for each model is summarized as follows (Moore and Thompson 1980): the aulocogen model is based on the limited distribution and thickness of volcanics, supposed "alkajic" character of the volcanics and presence of continuous underlying sialic crust. The model of subduction followed by continental collision is based on the minimum estimated thickness of volcanics of at least $10 \mathrm{~km}$, abundance of . tholetitic and calc-alkalic volcafics and association of the volcanics with the "orogenic" plutons. Moore and Thompan (1980) favour the model of subduction followed by continental collision presented by Brown et a). (1975).

* Term proposed by Moore and Thompson (1980) for the late phase of the "Grenvillilan orogeny". 


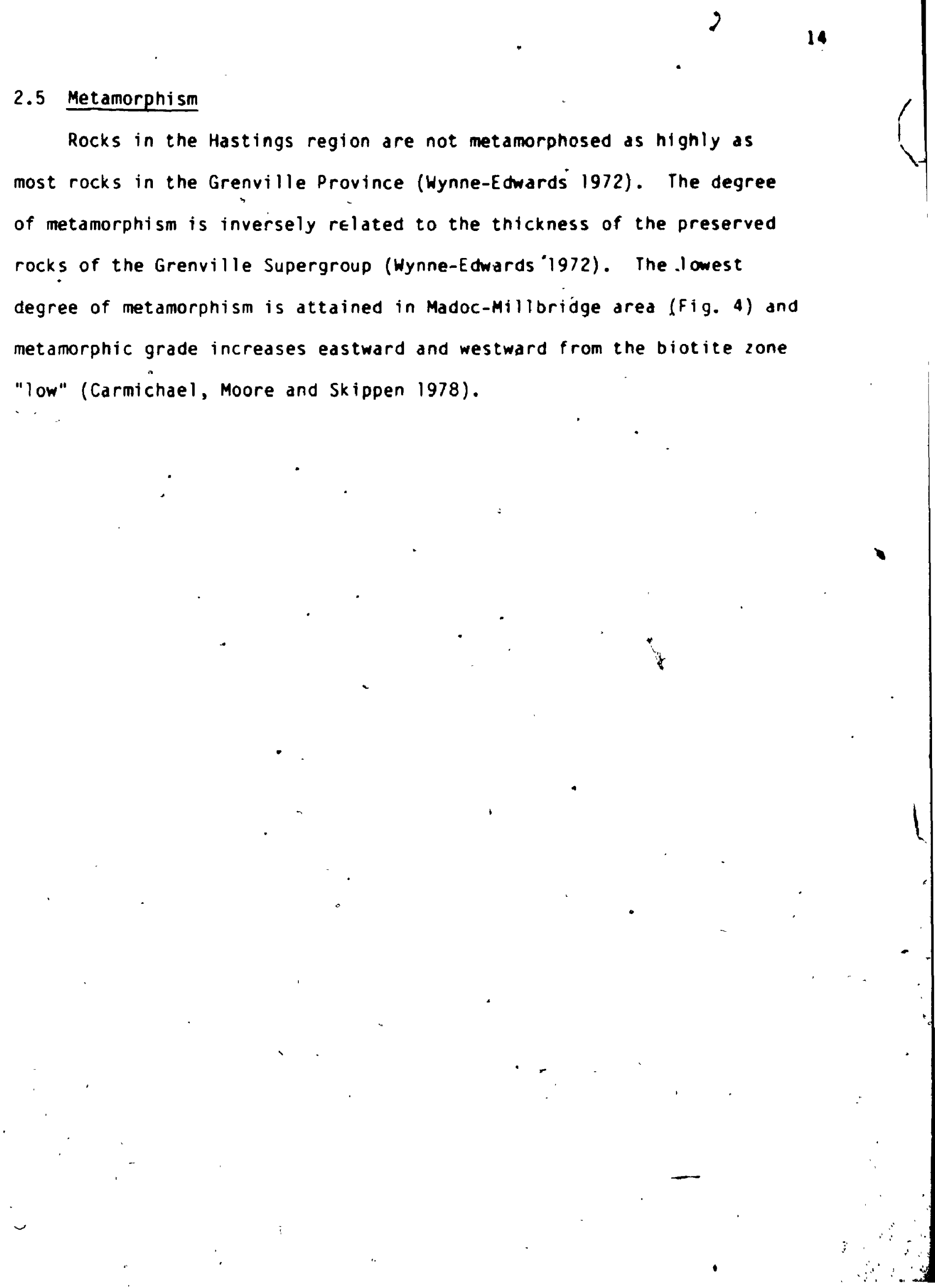




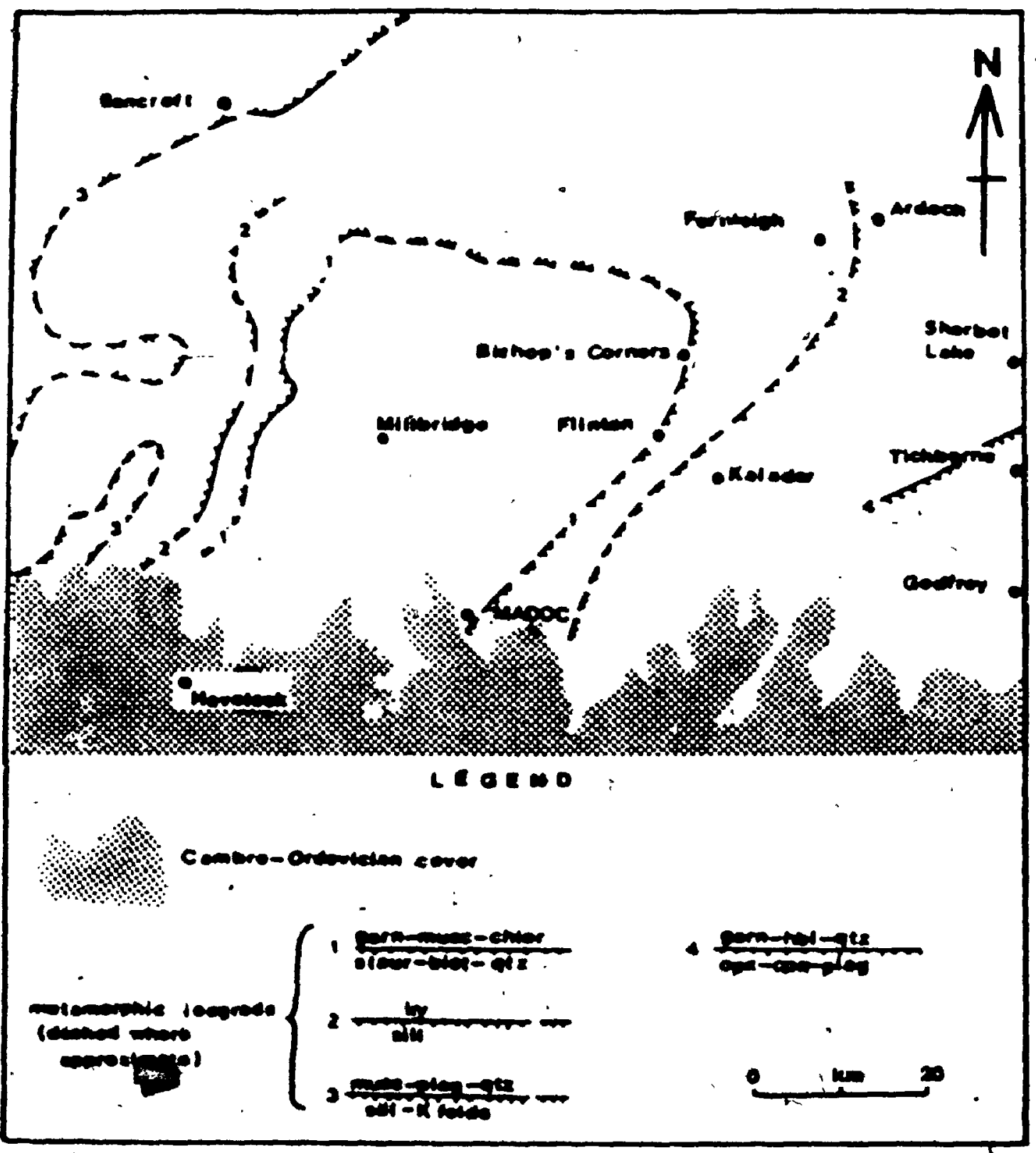

Fig. - Metamorphic isograds in Hastings region. (Adapted boom Carmichael. Moore and Skippen 1978). 
CHAPTER 3: GEOLOGY OF THE MADOC AREA

The Madoc area is tecated within the Hastings. Region. The geology of the Madoc area was mapped at the scale of $1: 31680$ by Hewitt (1968). Part of his work is reproduced in ordèr to demonstrate the geographic distribution of the lithological units (Fig. 5). Pleistocene unconsolidated deposits cover about $80 \%$ of the area.

The lithological legend of Hewitt (1968) is not entirely equivalent to the stratigraphic interpretation as presented in the section on regional geology by Moore and Thompson (1980), and a simple correlation between the two is therefore impossible.

Geologists from the Ministry of Natural Resources are currently studying the geology of the Madoc area and their work should ctarify the stratigraphic relationships. The results of their study were not available at the time of writing.

\subsection{Lithology}

The salic and mafic volcanic rocks (Fig. 5) were subdivided into Tudor volcanics, Madoc volcanics and Queensborough volcanics (Hewitt 1968). Tudor volcanics extend into Madoc township from the north. They are dark-coloured andesites and basalts. Basalts with green weathering. surface are composed mainly of hornblende and plagioclase with minor chlorite and carbonate. Locally they may contain talc and actinolite (Hewitt 1968). The Madod volcanics outcrop on highway 7, about $3 \mathrm{~km}$ west of Madoc and on highway 62 about $2 \mathrm{~km}$ north of Madoc (Fig. 5 ). These black, grey-green or pink volcanics range in composition from 
0

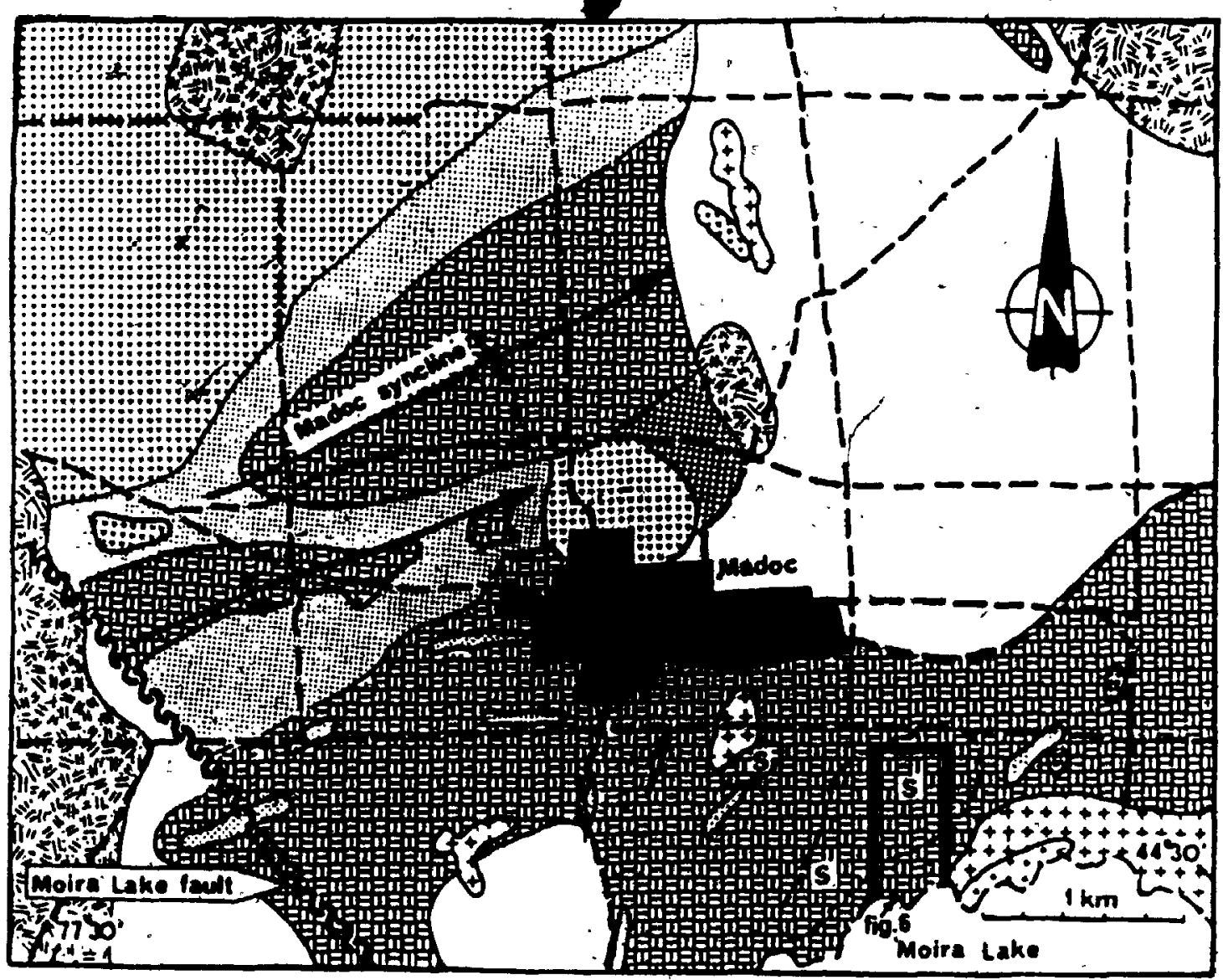

Fig. 5 - Lithology of the Madoc ared, simplified map from (Hewitt 1968). Pleistocene, unconsolidated deposits $\square$; Paleozoic Black

River limestone $\mathbf{X e d ;}$; Precambrian rocks: graniteEt]; diorite or gabbro $\because:$; pelitic rocks and conglomerate :::: ;

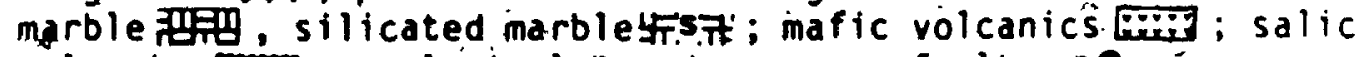
volcanics ; geológical boundary $\sim$; fault n $\mathbf{\sim}$;

fold axis road $\sim-$ r 
andesite to rhyolite (Hewitt 1968). Texturally these rocks may be described as massive lavas, pillowed lavas, amygdaloidal lavas, tuffs and agglomerates (Hewitt 1968).

Queensborough salic volcanics outcrop mainly in the Queensborough syncline loçated $6 \mathrm{~km}$ northeast of Madoc (outside of the area covered by Fig. 5), stratigraphically above the Tudor volcanics (Hewitt 1968). They consist of two mai/n types: rhyolite and felsite, and are associated with black pyritfferous slates (Hewitt 1968).

The metasedimentary rocks "are comprised of conglomerate, slate argillite and pelitic schist. Conglomerate bands referred to as "Skootamatta conglomerate" contain pebbles of andesite, rhyolite, dolomite marble, quartzite, quartz, phyllite and plutonic rocks (Moore and Thompson 1980).

Calcitic and dalomitic marble is thick liftorogic unit, varying in colour from, white; buff, blue-grey, green tobtack (Hewitt 1968).

Several granitic plutons occur in the Madoc area. The Elzevir pluton is located about $5 \mathrm{~km}$ northwest of Madoc. The Addington pluton is located $75 \mathrm{~km}$ southeast to east of Madoc. The Moira pluton is located about $2 \mathrm{~km}$ southeast of Madoc. The latter is well exposed on the north shore of Moíra Lake (Fig.. 5). It" is a pink granite composed mainly of albite and quartz with minor microcline (Hewitt 1968).

The Ordovician Black'Riveg"Formation is composed of reddish, greenish.or brown arkose at the base. Chocolate-brown, limestone overltes the basal arkose, and it is overlain by medium grey, medium to thick bedded limestone (Hewitt, 1968). 


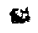

\section{2 - Structural geology}

The Queensborough and Madoc synclines were recognized by Hewitt (1968). The Queensborough syncline, $6 \mathrm{~km}$ northeast of Madoc, is outside of the area covered by figure 5. It is an upright syncline and its plunge was tentatively estimated at $80^{\circ}$ towards southwest (Appendix 11). The variations in plunge direction of parasitic folds indicate at least two periods of folding. The eastern limb of this syncline is trúncated by. a northwest-southeast trending fault. The Madoc syncline, north of the village of Madoc (Fig. 5), is overturned to the north, its

$y^{\prime \prime}$ axial surface trends northeast and its plunge was estimated at $50^{\circ}$ towards $116^{\circ}$ (Appendix IF).

Minor folds are abundant in marbles. Most are cylindrical or slightly conical. Their plunges' vary in direction and steepness. These variations are probably due to at least two different periods of deformation.

Two major fault systems have been identified and described in the section concerning regional geology. The faults belonging to these have been reactivated several times (Lumbers 1967). Movements along the faults of the west to northwest system postdate the movement along the east-northeast system (Lumbers 1967). Both Precambrian and Ordovician rocks were affected (Hewitt 1968).

The Moira Lake fault zone (Fig. 5) which acts as a structural control for the fluorite-barite-calcite deposits belongs probably to the west to northwest system. The striations and slickensides indicate hortzontal displacement (Hewitt 1968). However, vertical wall rock striations were also observed (Wilson, 1929). 
The horizontal displacement along one fault of the Moira Lake system was estimated at 100 feet (Wilson:1929). For the majority of the faults, however, the displacement remains unknown.

Minor faults are believed to be abundant in the area (Lumbers 1967). They are best exposed in the underground workings of the Henderson deposit (Hewitt 1968). They are mostly strike-slip faults along'which the displacement is impossible to determine, or faults with apparent vertical displacement of less than 2 metres.

\section{3 "Metamorphism}

Preciambrian rocks of the Madoc area were subjected to upper greenschist façies metamorphism (Carmichael, Moore and.Skippen 19978). The upper limit of garnet-chlorite (greenschist-amphibolite facies boundary), locáted about $3 \mathrm{~km}$ southeast of Madoc trends' northeast (Fig. 4).

\subsection{Mineral deposits}

Madoc is known for its talc and barite-fluorite-calcite deposits. Several other non-metallic deposits and industrially useful rocks currently being mined are nepheline syenite, marbie, act"nolite and granite. Fivorite, barite, apatite, mica, feldspar, corundum, garnet, andesite, rhyolite and slate have been mined in the past (Lumbers 1967). Mica deposits are being currently investigated.

Irón, gold, lead, arsenic and pyrite deposits were also exploited

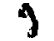

in the past. A-detailed account of these mineral occurrences is given by Hewitt' (1964). 
CHAPTER 4: GEOLOGY OF THE HENDERSON MINE AREA

The surface area around the Henderson mine and related deposits was mapped in detall (Fig. 6, in the back-pocket). More than $80 \%$ of the area is covered by overburden and the outcrops are irregularly distributed.

\subsection{Stratigraphy}

The sedimentary rocks of the Grenville Supergroup in the Henderson Mine area probably belong to the Mayo Group (Moore 1983, personal communication). The lack of stratigraphic polarity indicators makes.it impossible to positively identify top and bottom of the stratotype section (Fig. 7). The stratigraphic relationship of the Mayo Group, in which sedimentary rocks overlie the metavolcanics (Table 1) was applied in construction of stratotype section (Fig. 7).

The thicknesses of various lithologic units cannot be referred to as stratigraphic thicknesses because of the extensive folding. The mafic to intermediate laminated metavolcanics and sediments of volcanic origin are the oldest rocks in the mine area. Their contact with the Moira, Lake granite is discordant. Their thickness in the hap area cannot be determined, because the contact between metavolcanics and overlying metapelite is not exposed. Metapelite, which contains near its top chlorite-rich horizon and a feldspathic porphyry sill, does not outcrop. 

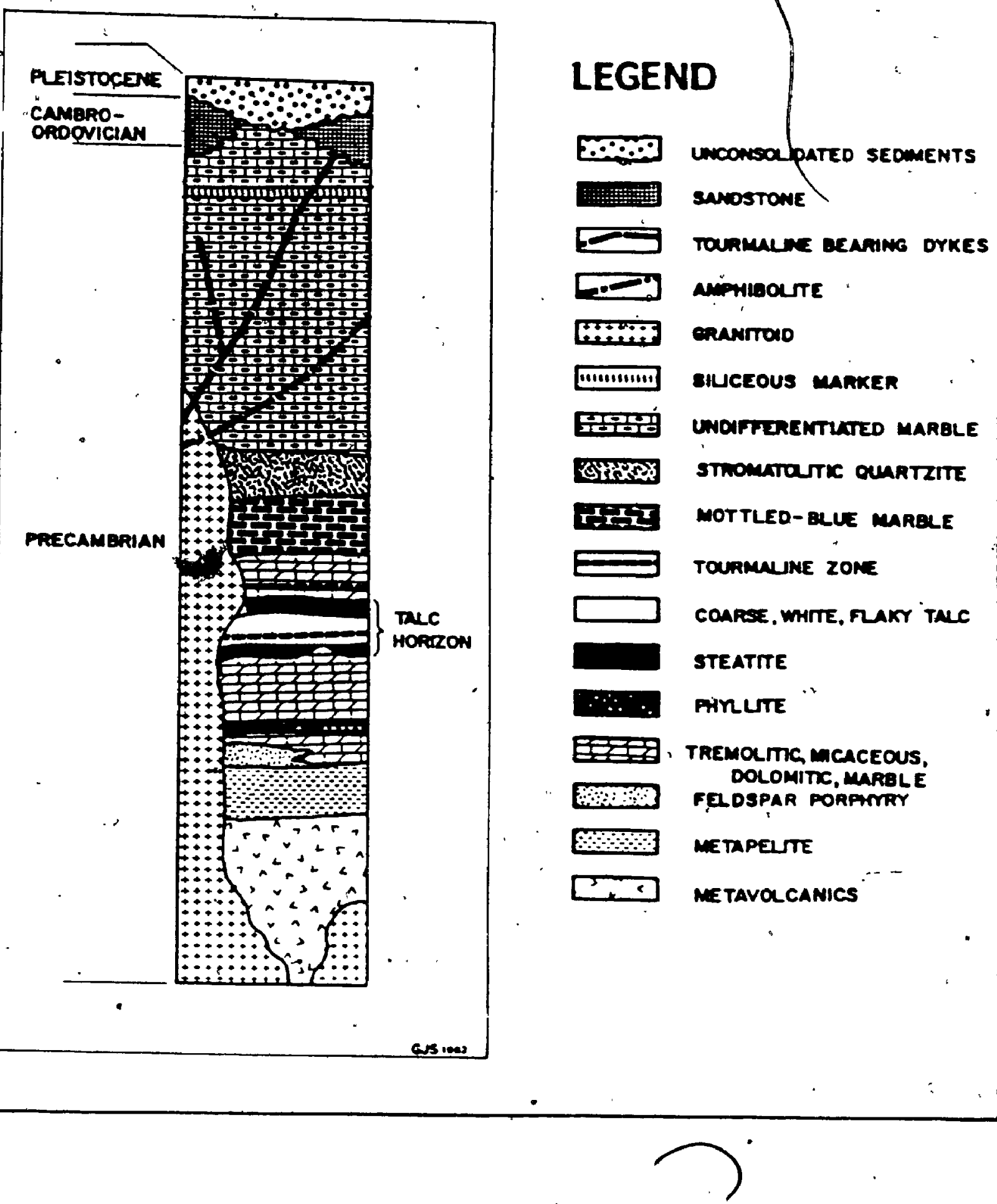

Fig. 7 - Stratöype section of Henderion Mine area. 
Laminated tremolitic micaceous marble overlies the porphyry sill and/or metapelite. Its thickness is estimated at less than 30 metres. Talc bearing "phyllite" more than 4 metres thick is contained within láminated tremolitic micaceous carbonate. Tremolitic, micaceous dolamitic marble overlies the talc bearing "phyllite" and hosts the main talc horizon (Fig. 7). Tremolitic, micaceous marble forming the footwall of the maln talc-bearing zone is over 15 metres thick and that forming the hanging wall is about 3 metres thick. The main talc bearing horizon varies in thickness from 10 metres to 15 metres across the Henderson deposit.

A stromatolitic quartzite overlies the tremolitic micaceous marbile. It is about 10 metres thick north of the Henderson deposit (Fig. 7). "A "mottled blue" marble overljes stromatolitic quartzite. Its thickness averages from 3 to 5 metres depending on deformation. Stromatolitic quartzite, black talc bearing "phyllite", tremolitic micaceous marble and "mottled blue" marble are usèful marker horizons. A thick metadolomitic sequence overlying the "mottled blue" marble dops not contain any good markers except tiwo sil)iceous beds $(1.5$ metres thick).

The Moira gran'te* butcrops in the southern portion of the mapped area (Fig. 6 in the back-pocket). The contact between Moira Lake granitoid and metavolcanics and/or.metasediments of volcanic origin is discordant. The amphibolițe outcrops on the shore of Moira Lake are believed to be" older than the Moira granite (Bain 1960).

* Moira granite was-alco metamorphosed but prefix "meta" is not used. 
Late amphibolite ( 5 to $300 \mathrm{~cm}$ thick) dykes cut all the rock units present except the Paleozoic rock and Plelstocene unconsold dated deposits. Several tourmaline bearing dykes occur in the area. They are believed to be related to the Moira Lake complex intrusion (Bain 1960). The age relationship between amphiboltte and tourmaline dykes is not clear. However, coarse calcite-quartz veins are younger than amphibolites.

- Paleozoic rocks form discontinuous, flat lying sheets unconfórmably covering all the units previously described. Some of the dykes may be post-paleozoic, however, it, is not likely. All the barite and fluorite veins of the Madoc area are of post-paleozoic ages. Paleozoic rocks outcrop very rarely. Pleistocene unconsolidated geposits overlie unconformably all the units previously described.

The metavolcanics and metasediments of volcanic origin are cut by dark gray to black fine-grained dykes and some quartz-black tourmaline dykes. Except in the immediate vicinity of granite outcrops they are less deformed than the carbonates.

\subsection{Lithol ogy}

The descriptions of the rocks of the Henderson mine area (Fig. 6) are based on macroscopic and microscopic pbservations*. Individual lithologic units are described in stratigraphic order (Fig. 7):

4.2.1 Metavolcanics and metasediments of volcanic ortinin :-

They were described as amphibolite by Hewitt (1968). Outcrops of this unit are abundant north of:Moira Lake (Fig. 6). Their thickness

* For detailed description of the thin sections, see Appendix III. 
cannot be evaluated since the contacts with the Moira granitold are discordant and the position of the contact with overlying metapelites is unknown. The metavolcanics follow a trend sub-parallel to the Carbonates (strike $\mathrm{N} 45^{\circ} \mathrm{E}$, dip $80^{\circ} \mathrm{NW}$ ). The aro banded medium to dark green and light pink to gray, or massive and green. Individual bands are 0.5 to $1.5 \mathrm{~cm}$ thick (Plate 1 ) and can be tracod for several metres. Laminated rocks were probably deposited in volcano-sedimentary environment. A light pink to gray component of these rocks is comprised mainly of aphanitic carbonates (mostly calcite). Dark and medium green portions consist of a very fine-grained to aphanitic mass comprised of actinolite chlorite, biotite, hematite and feldspar. Locally these rocks contain disseminated sulphides and pods of sulphides up to' $10 \mathrm{~cm}$ across. Some very dark and thick beds (up to $2 \mathrm{~m}$ thick) observed within banded rocks may be massive flows.

\subsubsection{Metapelites:}

Metapelites do not" outcrop in the map area. Information about then was obtained from Bain (1960) and from diamond drill core which cut the East deposit and intersected the upper contact of the metapelites.

Metapelites from the diamond drill care are dark brown, fine-grained with schistose texture. They are composed of brown layers surrounding lenses of light gray or beige colour. The lenses are usually less than $0.5 \mathrm{~cm}$ thick and less than $5 \mathrm{~cm} .1$ ong:

The rock is composed mainly of quartz. calcite and phlogopite with accessory pyrite, zircon, tourmaline, sphene and apatite. Quartz occurs as anhedral, crystals $(<0.5 \mathrm{~mm})$ concentrated in bands (Plate 2$)$. 


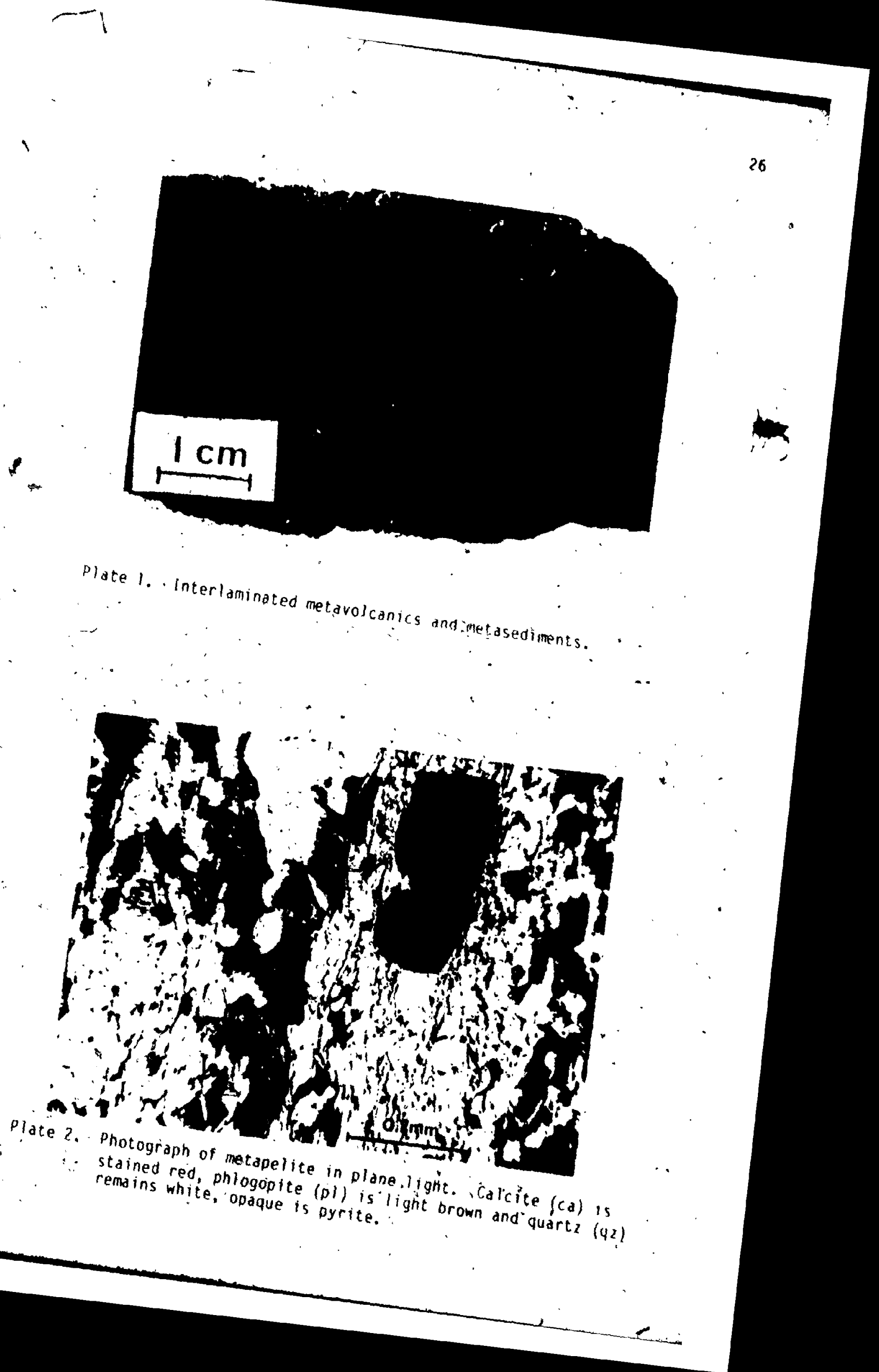


Calcite occurs in onhedral grains less than $1.5 \mathrm{~mm}$ across averaging $0.7 \mathrm{~mm}$.

Phlogopite flakes ar mostly smaller thah $1 \mathrm{~mm}$ and are concentrated" in parallel planes giving the rock its characteristic laminated. appearance.

Pyrite is a common accessory mineral. It occurs as euhedral to subhedral crystals (cubes), which are most abundant in phlogopite. bands. Some of the pyrite crystals contain phlogopite and quajartz inclusions. Pyrite may make up locally more than 10\% by volume of the rock.

Sphene is distributed "through the rock as small euhedrál grains of reddish colour. Very fine zírcon graiss create radiation halos in phlogopite flakes. Apatite and tourmaline are very rare accessories.

\subsubsection{Feldspathic porphyry}

Feldspathic porphyry is not exposed in the Heriderson mine area. The only information wave about it is from diamond arill cores which cut the East deposit. It occurs as layers (or lenses), less than $1.5 \mathrm{~m}$ thick. It overlies or is intercalated with metapelite. It is light brown or light gray, aphanitic, hard and brittle. In hand specimen it resembles the rhyolite.

However, the rock is composed mainly of plagioclase (88\%), which occurs as a fine ground mass ( $<0.2 \mathrm{~mm}$ ) and euhedral or subhedral phenocrysts ( $<1 \mathrm{~mm}$ across) which form about $15 \%$ of the plagioclase crystals. Amphibole ( $7 \%$ of the rock) occurs as radiating (prisms <1 mm) and is disseminated in the fine plagioclase ground mass. Coarsest 


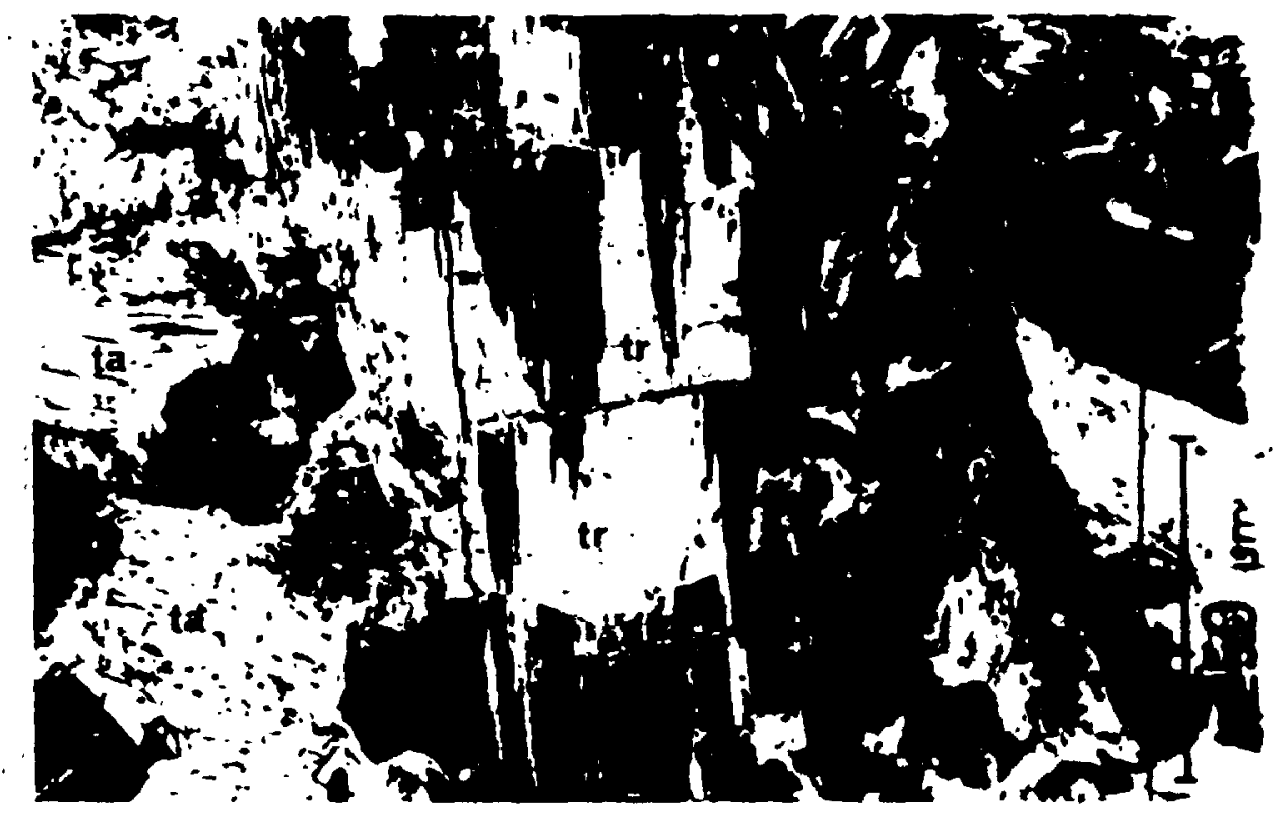

$n$

Plate 3. Laminated phyllite. Calcite (ca) is stained, tald, (1a). tremolite $(t r)$.

Plate 4. Coarse, flaky, white talc-bearing rock. 
amphibole grains are associated with hairline fractures filled by calcite ind chlorité. Yalcite iś anharal (<0.5 mm), and forms about $1 \%$ of the rock anss. Cnlorité $(<2 x)$ occurs in fractures or as alteration of certain amphibole grains. Subhedral opaque grains $(\langle 2 \%)$ are disseminated in fine-grained plagioclase matrix.

\subsection{4 "pnyllite"}

This unit is best observed underground on the third level (Fig. BL, Dut it was also reported on the seventh level of the Henderson nine $(0$. Ogden and $D$. Cook 1981, personal communication). The seventh level of the Henderson déposit cowre not be systematically mapped because of the dangerous conditions in the mine. "Phyllite" al:0 ou"crops at the - surface (Fig. 6): It can be used as a marker norizon.

The rock has a charcoal black colour but locally it appears lead gray (especially on the weathered surface). It is characterized by phyllitic sheen. It occurs either as a laminated or massive variety.

d) Laminated variety of "phyllite"

Lamind:ed phyllite is. comprised of actinolite, calcite and chlorite or from calcite and talc. Actinolite occurs as randomly Dwented prisims and needles I mm in length. It is strongly altered and replaced by talc and calcite (Plate 3).... Calcite replaces actinolite but if also occirs as bands in association with chlorite or talc. Chlorite is sligntly pleochroic and it occurs in form of irregular, deformed llades. Sorde chlorite grains are $0.5 \mathrm{~mm}$ across but most flakes are * smaller ind $0.2 \mathrm{man}$ 
b) Massive variety of "phyllite"

Massive variety is composed mainly of actinalite, talc and dolomite. Aetinolite occurs ás fine blades and prisms $(0.5 \mathrm{~mm})$ averaging about $0.2 \mathrm{~mm}$ in length. It makes up to $50 x^{\circ}$ of the rock.

Dolomite is preşent only as fine remants $(\leqslant 0.2 \mathrm{~mm})$ within, the talc mass (5\% volume). Talc appears as fine cloudy alteration covering actinolite blades and prisms. "The presence was confirmed by $x$-ray diffaction. Opaque minerals (sulphides) are irregularly distributed through both massive and ganded variety of "phyllite". "They are mostly in form of euthedral crystals $(\leqslant 2 \mathrm{~mm})$ or more rarely streaks:

\subsubsection{Tremolitic, micacequs marble (Footwall)}

It conformably overlies the "phy?lite" and forms the fcotwall of the talc deposits (Fig. 7). It is composed essentially of calcite (30\%), mica (38\%), tremolite (15\%), serpentine (10\%) and talc (5\%). All the accessory minerals present (opaques, tourmaline and sphene) make. less than $2 \%$ of the rock by volume. Tourmaline is.often concentrated in concoraant bands. Caicite, mica, and quartz are observed in contact with each other. Calcite occurs as anhedral crystals ( $2 \mathrm{~mm})$ with well-developed cleavage. Twinning is not abundant, Strongly altered calcite crystals are elongated subparallel to the mica flakes ( $<2 \mathrm{~mm}$ ). Tremolite occurs as prismatic cryştals which locally. reach $1 \mathrm{~cm}$ in size but in general it is less than $0.7 \mathrm{~mm}$ in length.

Talc occurs as cloudy alteration on tremolite. Non-identified opaque-minerals ( $<0.5 \mathrm{~mm}$ ) occur as anhedral grains. Sphene is present in the form of reddish euhedral crystals $(<0.4 \mathrm{~mm})$. Tourmaline is red 


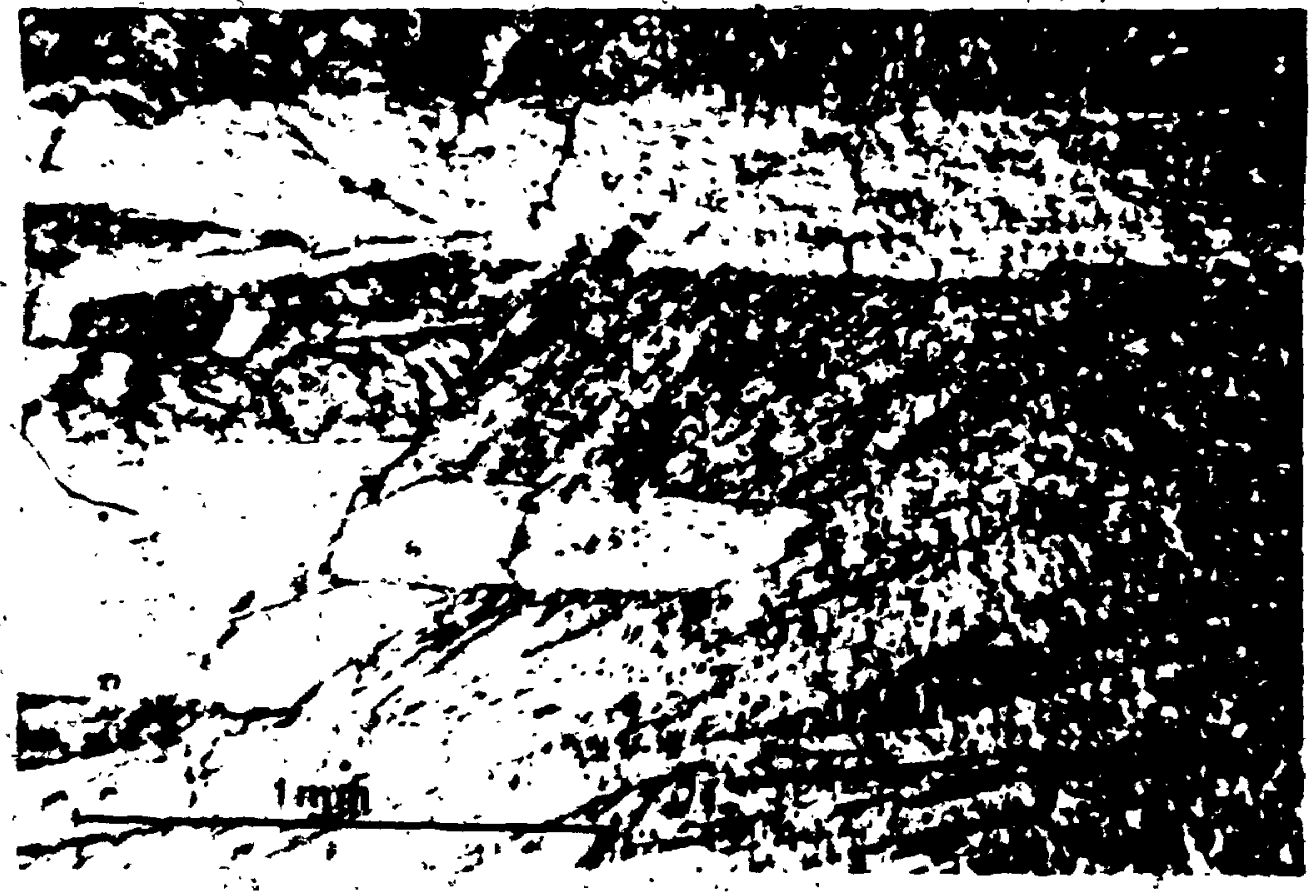

llate 5. Coarse, flaky. white talc-bearing rock. Monomineralic zone composed of talc.

Plate 6. Stedtite (unustally. rich in opaques). White bands consist predominantly talc; dqlomite and tremolite. Green phase is serpentine (sup). "Dark patches are pyrite grains. 


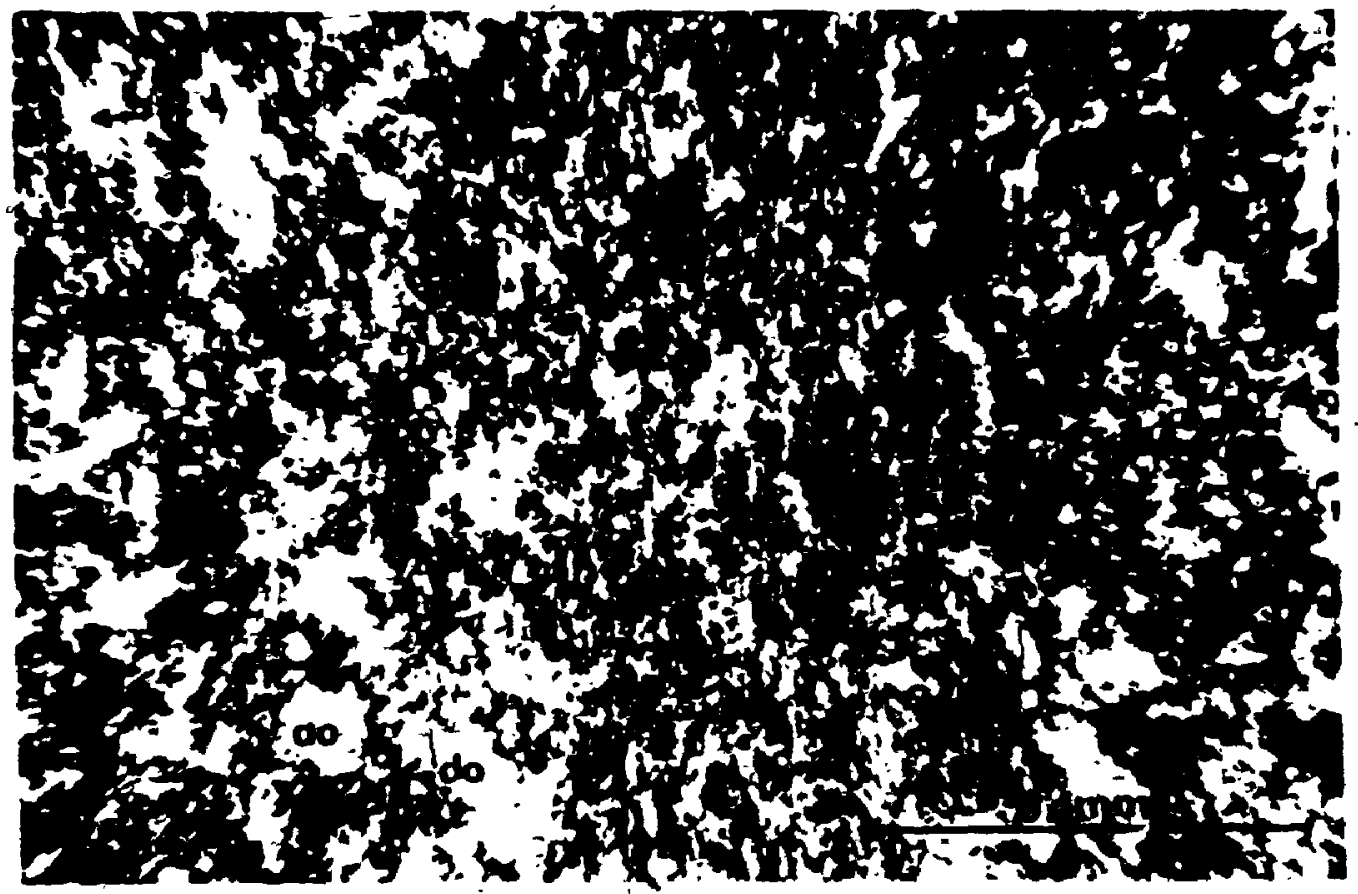

Plate.7. Steatite. $t r=$ treinolite needles, do dolomrte. lorker brown mass consists of inixture of tale (tk) and serpenthe (sup) (plain light)

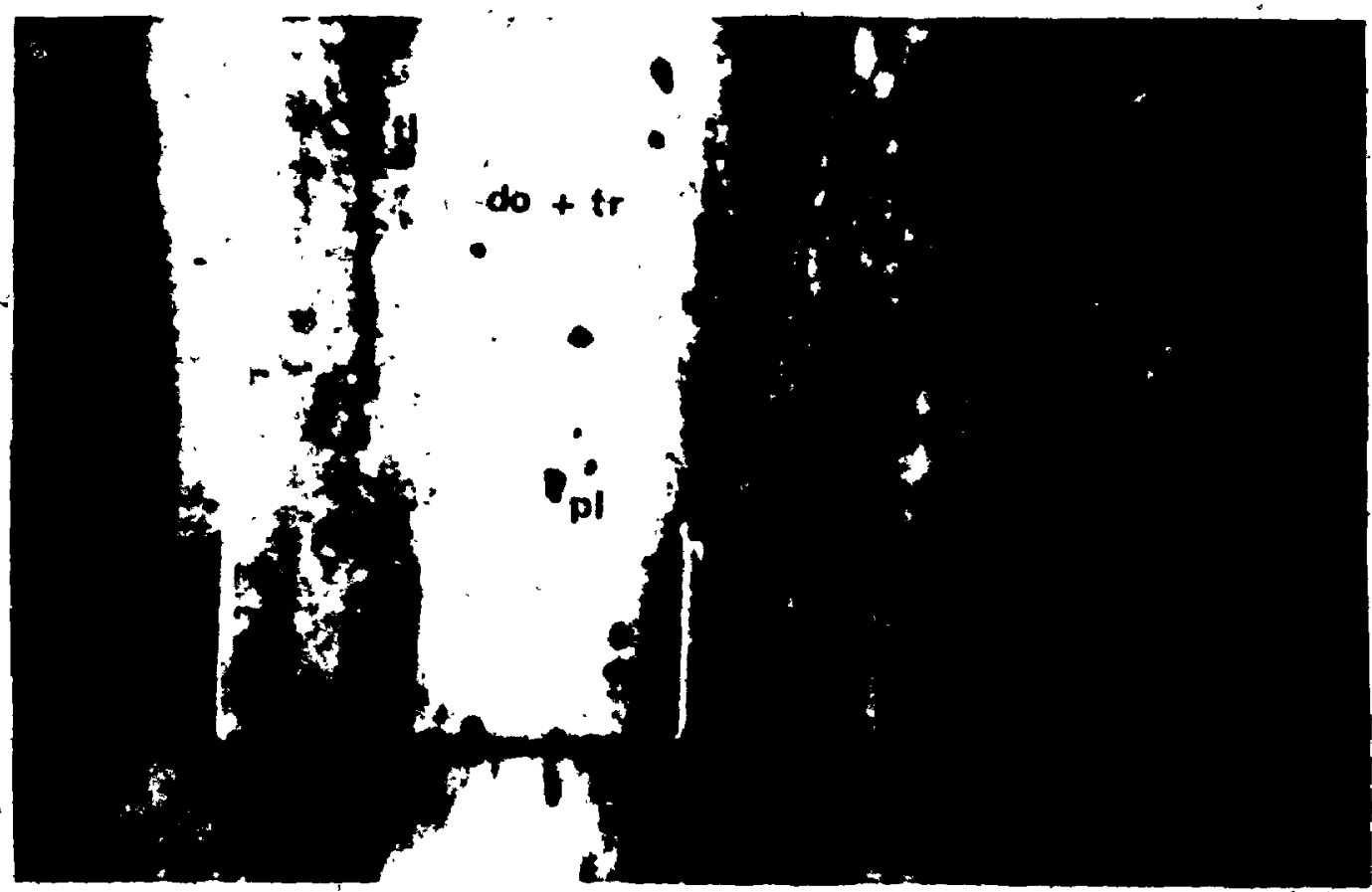

Plate 8. Tremolitic micaceous, dolomitic marble. (p) - phlogopite, sill) serpentine bearing band do + tr - tremolite and dolomite bearing band. $t l^{*}$ - euhedral toumaline crystals). 
and strongly altered. It occurs as subhedral crystals $(0.4 \mathrm{~mm})$. if embedded in serpentine or strongly deformed it it is hosted by impure . stliceous marble. Tremolitic micaceous marble of the footwall is mineralogically and texturaliy similar to the tremolitic micaceous marble which forms hanging wall of the talc deposits (Fig. 7). "It . differs from the latter by higher mica content and by more deformed nature of lenses and bands.

\subsubsection{Talc horizon}

The talc horizon is hosted by tremolitic micaceous marble. The contacts between the talc horizon and tremolitic micaceous marble may be sharp or gradational. It does not outcrop except in the area of borehole C.T. 82-1. (Fig. 6, back-pocket). Thickness of this talc rich zone variès from a few centimetres (wilson 1926) to 30 metres. The talc bearing zone consists of two major rock types: arse flaky talc bearing rock (plates 4 and 5 ) and an aphanitic to fine-grained talc bearing mass (Pkates 6 and 7) usually referred to as steatite (Fig. 7). The thickest known segments of the talc horizon are known as the Henderson, Conley $\therefore$ and East deposits. In this paper they are referred to as Henderson type talc dépositṣ.

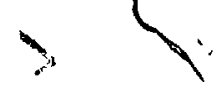

Petrologic, mineralogic and geochemical investigations were. concentrated on the samples from the Henderson deposit: Detailed rock descriptions and geochemistry are given in the section: "Henderson deposit".

4.2.7 Laminated micaceous tremolitic marble (nạging wají)

It overlies the talc horizon (Fig. T) and is conspicuous by its 
banded appearance, and colour (plate 9). The thickness of bands varies from 2 to. $50 \mathrm{~mm}$. Most of the bands have regular and sharp contacts, "but in places they are highly irregular and may appear as lenses. - The colour of bands varies from white, light green, amber to brown, purplish and medium gray or medium green.

The main mineral component's are dolomite $(60 \%)$, calcite $(20 \%)$. tremolite $(20 \%)$, mica $(5-15 \%)$, talc $(5 \%)$ and locally serpentine (20\%). Sphene, apatite and sulphides are minor components. Dolomite is light gray to light green (when strongly serpentinized dark green) and rarely white. It is usually fine-grained but i.t may be coarser. Mica (ohlogopite and/or muscovite) occurs in flakes and forms the. brown band5. "Tremolite occurs usually as prismatic crystals $0.05 \mathrm{~cm}$. to; $5 \mathrm{~cm}$ in lekgth often altering into talc rich fine-grained mass. The coarsest tremolite crystals are present in narrow zones subparallel to the beding.

In the areas' where tremolite crystals are fine $(3 \mathrm{~mm})$ and where micas are not abundant purplish quartz bands may be obseryed.

Individual quartz. grains are less than $1.5 \mathrm{~mm}$ across. Pyrite is distributed irregularly" through the unit in blebs or as cubes usually less than $3 \mathrm{~mm}$ across. Dravite forms concordant bands.

Chemical composition of several samples of micaceous tremolitic marble are givén in the chapter devotéd to geochemistry.

\subsection{8 "Mottled-blue" Mapble}

- It displays irregular patches or beds of dark blue-gray and light coloured (greenish, yellowish or.grayish white) material. A coarsely 


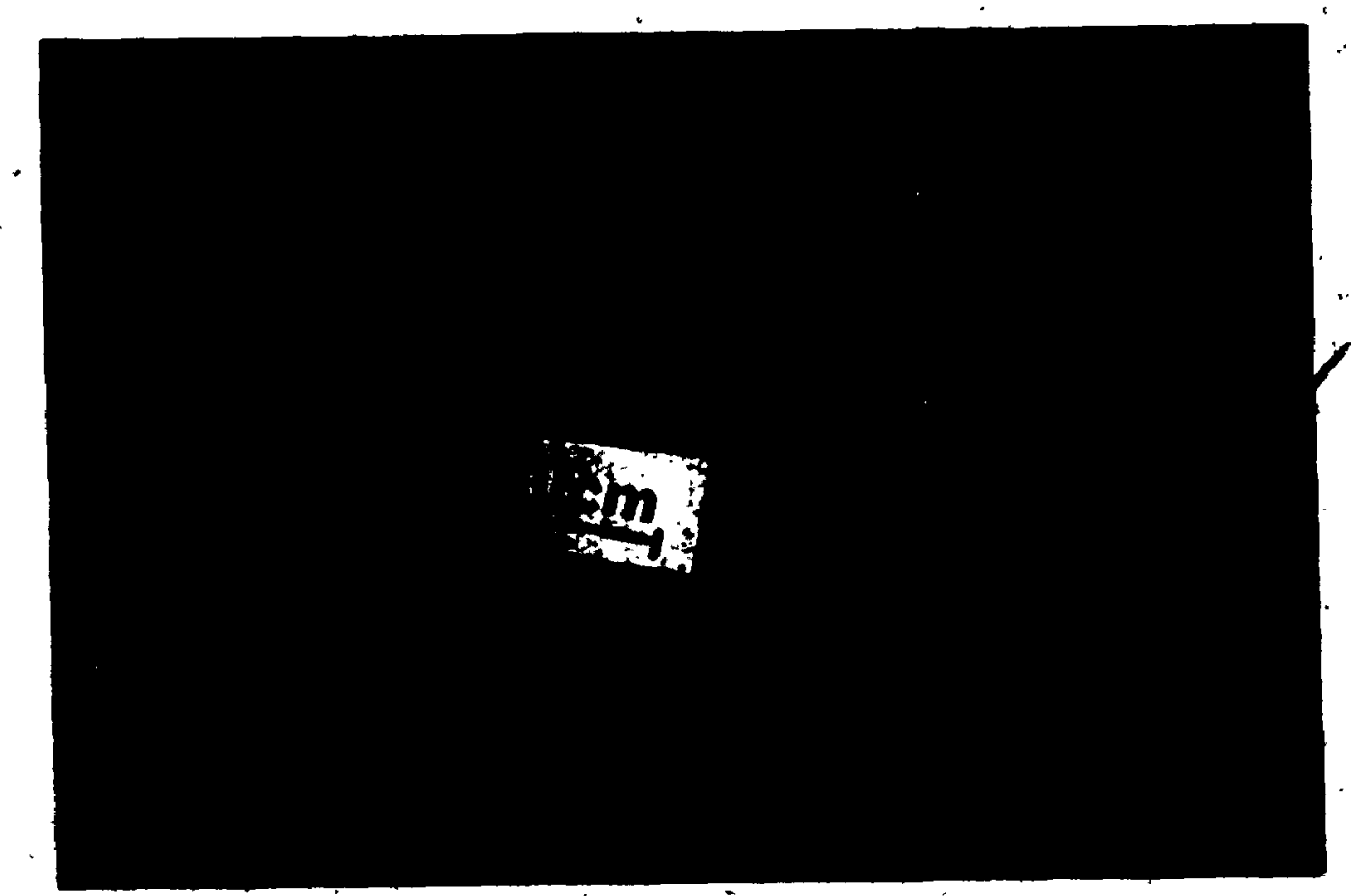

Piate 9. quartizite with stromatolitic texture: (ca+tr) represents calcite - tremolite zone, quartz $(q z)$ is darker and transluscent.

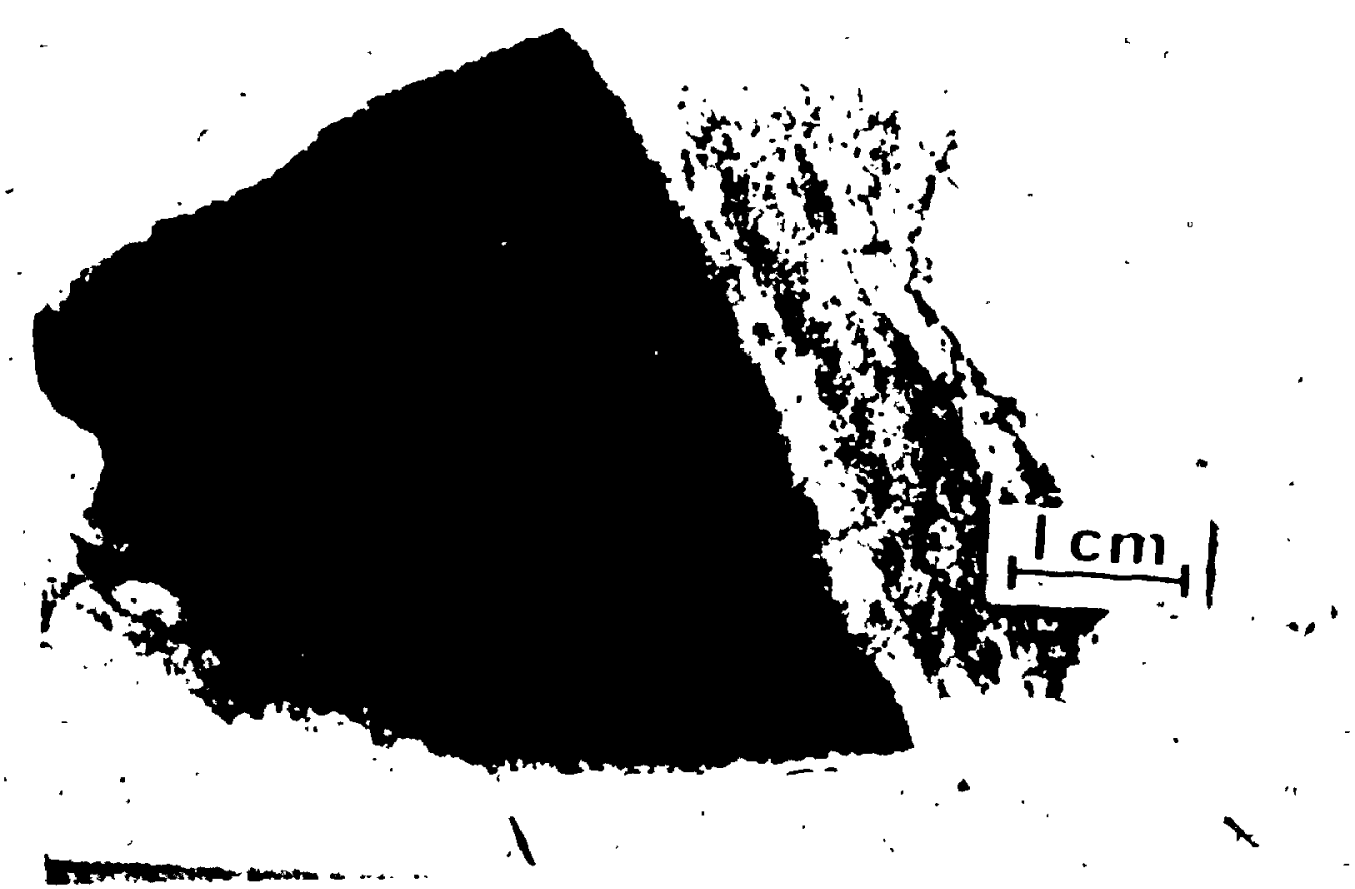

P? ate 10. Mottled-blue marble. Calcite is stained red. White material is tremalite-dolomite marble. Dark material is dolomitic marble. 
banded $(5-50 \mathrm{~cm})$ variety. of this carbonate is well exposed in the small quariry about to metres.north of the Henderson open pit and underground (Figs. 6 and 8 in the back pocket).

The dark gray component of the rock is composed essentially of fine-grained ( $<2 \mathrm{~mm}$ ) anhedral dolomite ( $80 \%$ ) with fine (<2 $\mathrm{mm})$ prismatic tremolite or actinolite $(<15 \%)$, phlogopite $(<5 \%)$. Calcite is present as fracture fillings only. The dark blue gray colour may be due to extremely fine organic inctusions. In several areas, the typical blue gray colour of marble is of substantially lighter tone. These àreas correspond usually to zones of strong structural deformation. The light component of the mottle blue-marble is comprised mainly of medium to coarse-grained $(2-5 \mathrm{~mm})$ dolomite $(80 \%)$ and caarse $(3-15 \mathrm{~mm})$, tremolite $(20 \%)$. The coarsest tremolite prisms are found near the céntres of light material (no calcite is present in these areas):

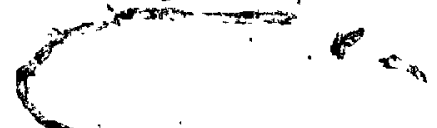

Light colouredkertions of the mottled blue marble are locally separated from the dark coloured portions by a thin lless than $3 \mathrm{~cm}$ thick) white to light gray'irregular zone (Plate 10). This irregular zone.is richin calcite. Apparent difference in the chemical analysis of the light and dark component (Table 2) is largely due to different proportions of insoluble tremolite. Tremolite was not digested (Sándomirsky 1954).

Poorly preserved "stromatolitic textures" were also observed in this rock. 


\subsubsection{Quartzite with Stromatolitic Texture}

This rock is best exposed underground on the hanging wall of. the Henderson deposit (Fig. 7). Its thickness is variable due to folding, and averages 10 metres. It is white to very light gray or greenish, and ftnely laminated (Plate 9$)$. The rock consists of quartz (40-70\%), talc $(5-15 \%)$, dolomite, calcite $(10-15 \%)$, and tremolite $(15-20 \%)$.

Quartz is granular and clqudy. Individual grains are less than 0.3 $\mathrm{mm}$ in size and appear annealed (grain contacts form.regular triple junctions with an angle of $120^{\circ}$ ).

Calcite is distributed in the quartz mass as individual granular. grains, less than $0.5 \mathrm{~mm}$ in diameter. Where calcite is enclosed by the tremoliti-talc mass its grain boundaries are highly irregular and the grains are coarse but never larger than $1.5 \mathrm{~mm}$.

Tremolite occurs as prisms with well-developed transverse fractures. "Individual prisms are less than $1.5, \mathrm{~mm}$ long. Most of the prisms.are smaller than $0.5 \mathrm{~mm}$ and occur as radiating aggregates. Tremolite is cloudy, and is commonly altered to talc and.calcite. Talc occurs only as a fine alteration of tremolite.

Dalomite is" present only" as few isolated grains, enciosed in quartz mosaic. Dolomite is g̈ranular. It was distinguished from calcite by staining. Calcite with apatite occurs as fine $\left(<0^{\pi} .3 \mathrm{~mm}\right)$ grains at triple junctions. formed by quartz or as individual grains in tremolite-tate mass. It makes less than. $1 \%$ of the rock.

Minerals in contact with each other are: quartz-'talc-calcite and quartz-tremolite-talc. Microscopic examination also reveals that the stromatolitic texture is formed by the alignment of fitie $(0.5-2 \mathrm{~mm})$ Ignses of quartz along the horizons parallel to the stratigraphy. The 


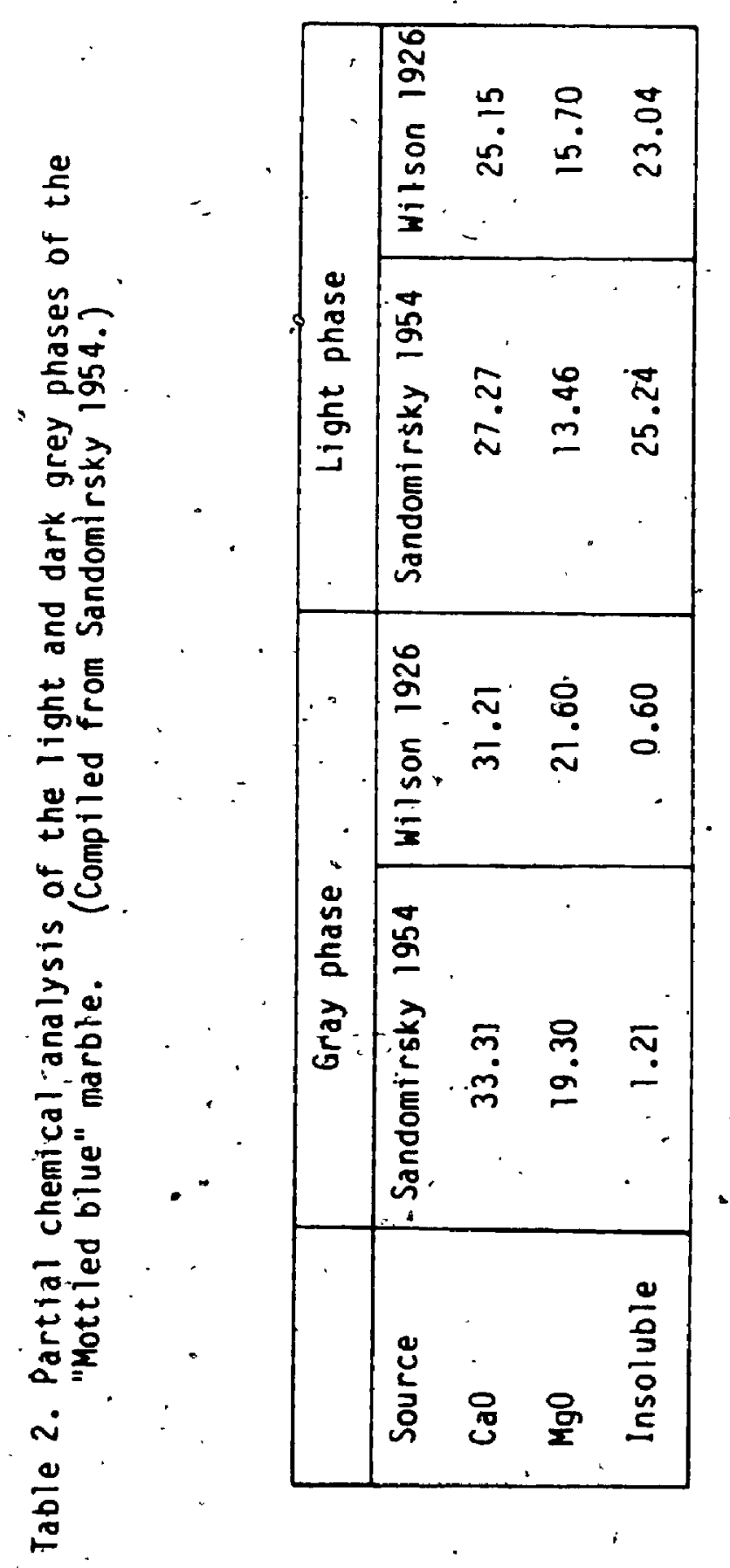


individual lenses are composed of a very fine euhedrai, granular aggregate and gre separated by talc; calcite and tremalite from other Ienses.

The origin of the above described stromatolitic texture has been debated by several authorg. Logan.(1864) believed that these textures were fossils, of ancient organic life. He termed these textureș Eozooncanadense. Later authors (Tarr and Keller 1940) believed that the stromatolitic texture was produced by metamorphism of chert layers.

The most recent. investigations (Bourque et al. 1982) support Logan's hypothesis. Stromatolitic textures are not restricted only to this stratigraphic unit. Poorly preserved "stramatolitic" textures were also observed in the adjacent "mottled blue" unit.

\section{4:2.10 Moira Lake granite}

The Moira Lake granite is represented, in the map area only by. outerops of pink to.gray grantitoid an the north shiore of Moyra Lake (Fig. 6). The outcrops of granitoid

$80 \mathrm{~m}$ southeast of Conley workings were mapped and'described as "hyprid. phase", of Moira Lake granite (Bain 1960;, Hewitt 1968). These outcrops are cream to very light pinkish on the weathered surface and display faint layering (possibly primary sedimentary bedding). Concentration of mafic minerals varies from $5 \%$ to $30 \%$ by volume:

Orthoclase, plagioclase, quartz, biotité, chlorite, clinozoisite, . hematite, pyrite, magnetite and zircon were identified in thin section. Plagioclase (20,60x) is hypidiomorphic and shows, polysynthetic and carlsbad twinning. It may formi phenocrysts up to $1 \mathrm{~cm}$ across and alters to sericite and clinozoisite. Orthoclase (15-35\%) occurs as subhedral 
crystals $(1 \mathrm{~cm})$. Quartz $(5-25 \%)$ is fractured and it forms grains $5 \mathrm{~mm}$. Green biotite (5-25\% of the rock mass) is often altered to chlorite and it contains very fine zircons. Chlorite (7\%) is present in form of fracture filitings (in assoctation with hehatte) or as alteration product of biotite. Apatite (in trace) occurs as fine inc Torjons in plagiaclase. Zircon (in trace) occurs as inclusions in biotite. The hybrid intrusive phase was explained by Bain (1960) as an introduction of the Moira Lake granite into graywackes.

No radiometric age is available for Mofra Lake granite. However. if Moira Lake granite is an apophysis of the Addington pluton which occurs sevéral kilometres east of the mapped area (as claimed by Bain 1960), both' intrusions would have similar age. The radiometric $\mathrm{Rb} / \mathrm{Sr}$ age of the Addingtion plution is $1060 \pm 30$ Ma (Bell and 81 enkinsop 1980)..

4.2,11-Fracture Fillings of the Henderson Map Area

Several types of fracture fillings were observed on the surface and underground. They may beclassified as follows:

a) dark green to black amphibolite dykes

b) mica, pyrite and tourmaline-bearing véins

c) sulphide bearing fine-grained veins of siliceous appearance

d) calcite-filied cavities aṇd fractures

e) calcite-phlogopite-quartz-sulphide veins

f) talc-filled fractures

g) serpentine-filled fractures

h) chlorite-filled and hematite-filled fractures. 
a) Dark green to black amphibolite dykes are widespread in the mine area. They vary in thickness from 20 centimetres to 10 metres. The amphibolites have vartable texture and composition and are . locally sheared on their contact with dolomite. Because of their relatively high compentence when compared with carbonates they fracture easily. Fractures may be filled with hematite, pyrite, calcite, salmon-pink calcite-quartz veins or other fracture fillings. These dykes have been referred to as "madocite" by all prevjous workecs. "Madocite" has become a loosely used term in the Madoc area. The term was probably introduced by Wilson in 1926 (Sandomirsky 1954). Wilson (1926) reserved this term for fine-grained dark rock consisțing of fine, needle-like tourmaline crystals, tremolite, and minor pyrite. Wilson (1926) also noted that "madocite" dykes contained phlogopite near the margins. Later, all mine operators, and engineers called any dark coloured .. rock in the mine area "madocite". Dark.laminated dolostones, amphibolites, mica bearing shear zones, "phyllite" rocks or metavolcanics have been called "madocite" at orie time or other. Sandomirsky (1954) investigated several "madocite" dykes and concluded that tho rock is" far more complex in composition than described by wilsón (1926). Plagioclase, quartz, chlorite, pyrite, sphene, apatite; zircon, phlogopite, tourmaline (black and brown) and tremolite were identified in madocite dykes by Sandomirsky $(1954)$

b) Mica, pyrite and tourmaline bearing veins and shear zones are as comion as amphibolite dykes described in (a). They vary in 
thickness from $1 \mathrm{~cm}$ to 8 metres. In some cases type (a) and type (b) dykes found in the vicinity of the Henderson deposit may be filling the same fractures. These veins are composed of amber mica flakes $(2,5-5.0 \mathrm{~mm})$. Mica comprises between 70 and $90 x$ of the rock by volume. Pyrite occurs as euhedral crystals 0.5 to $3 \mathrm{~mm}$ in size and makes $5-15 \%$ of the rock. Sphene $(<1 \mathrm{~mm})$ and quartz $(<0.2 \mathrm{~mm})$ and apatite $(<0.3 \mathrm{~mm})$ are accessory minerals.

c) Sulphide-bearing fine-grained, veins of siliceous, appearance are observed on the third level of the Henderson mine and the ramp. These contain significant amount of sulphides (pyrite and/or arsenopyrite) as fracture nTings or disseminations. "These veins vary in size from $3 \mathrm{~cm}$ to 5 metres but are not abundant. Some of these veins are fractured in a manner described in (b). No thin section of this aphanitic or fine-grained material was made. .

d) Calcite filling - Several fissures contain. perfect, euhedral, smoky-gray calcita crystals 0.5-3 cm in size. These calcite crystals are locally covered by sulphides (marcasite?) smaller than $2 \mathrm{~mm}$. Other fillings or gouge may also be present in these fissures.

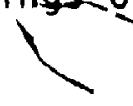

e) Calcite-phlogopite-quartz-sulphide veins were observed underground. The best expmple of this vein is located in the northern extremity of the dacline. Veins are invariably emplaced into brittle rocks (dark green to black amphibolite dykes or siliceous sulphide rich fine grained veins. They usually cut across the older dykes or veins at a right angle (Fig. 9): terminate at dyke (or yeins) contact and never extend more than 

$30 \mathrm{~cm}$ into marble. Calcite occurs as irregular masses up to $40^{\circ} \mathrm{cm}$ across, and constitutes $70=90 \%$ of the rock by volume. Mica is light coloured and forms hooks up to $2 \mathrm{~cm}$ across. 'It is not present, in all the veins. Quartz is smoky gray aphanitic. It does not form euhedral crystals; and it makes $k 0$ to $15 \%$ of the rock. Sulphides àre usually fine-grained $(<0.5 \mathrm{~cm})$ and are euhedral. Although both smoky-quartz and salmon-pink calcite are considered as favourable indicators in prospecting for radioactive elements, none of these pegmatites was investigated for the presence of uranium: This is probably because of the very limitgd. dimensions of these veins.

f) Tale-filled fractures and cleavages in marble are abundant in. the vicinity of the Conley. No. 3 shaft and in other areas investigated. by diamond drflling. They äre less than $2 \mathrm{~mm}$ thick but talc may make up to $20 \%$ of the marble, as it is controlled by practure cgecentration.

g) Serpentine filled fractures, were observed only. in the diamond drill hotes C.T. 82-20 and C.T. 82-2i (Fig. 6). They are dark green usuatiy $1-4 \mathrm{~mm} \cdot \mathrm{th} f \mathrm{ck}$ and have slightly diffused contacts. Marble which host these infillings appears also greenish, and bedding planes àre strongly contörded.

h) Chlorite-filled and hematite-filled hairline fractures occur mostly. in the thick undifferentiated marble sequence overlaying "mottled-blue" dolomite. 
Age rélationship between fracture fillings, dark gréen to black

amphibalite dykes and tourmaline bescing veins, is not well estaplished, but tourratine bearing veins are Fr.j35ly the oldest.

soldest. They are affected by folding and faulting. Siliceous, pyrite rich finégrained veins are order than salmon-pink calcite pegmatite.

Serpentinized zones and serpentine-filled fractures are specially related to amphibolite dykes; however, ho definite age relationships between the two could have been established.

- Chlorite and hematite-filled fractures postdate amphibolite and siliceous sulphide rich fine-grained veins. They are known to form a swarm south. of Henderson deposit and are most abundant in near surface. conditions. No dykes or fracture filling described above except the hematite chiorite-filled fractures are known to cut Paleozoic rocks.

\subsection{2 ,Pạleozoric rocks}

Paleozoic rocks of the Blact River group unconformably overlie the Precambrian'rocks. Percussion surface drilling in the Henderson mine area indicates that the thickness of cover may be tocally over $7 \mathrm{~m}$. .. The physican appearance of the paleozoic rocks varies considerably. Tho main types are recognized in the mine area based on physical appearance and colour:

$\therefore$ a) Rurplish to dark brown sandstione

b) green purplish, flaggy fine-grained silt.

a) The purplish to dark brown sandstone - It is generally poorly sorted; however, beds disolay sraded bedding. Individual beds vary from $2 \mathrm{~cm}$ to $50^{\circ} \mathrm{cm}$ in thickness. The grains are subrounded to subangular (1 to $8 \mathrm{~mm}$ in diamezer) composed mainly from quartz and 
feldspars. The cement consists of red hematite and some calcite. - This rock-type contains subángular to angular fragients are móst abundant near the discordant contact with underlying rocks of the Grenvilie Supergroup.

b) The grèen-purplish, flaggy silt - It may be deposited directly on the Precambrian rocks or on the purplish to dark brown Paleozolc sandstone. Macroscopic examigation indicates that this rock is composed mainly of feldspars, quartziand chlorite. The grains are less than $2 \mathrm{~mm}$ in diameter and subangular. 'The green coloured portion of the rock is predominantiand encloses, purplish, hematite stained lenses usually less than $10 \mathrm{~cm}$ in length and $3 \mathrm{~cm}$, in width. The purplish lenses are finer grained and appear more silitéous. Paleozolc rocks described above belong to the basal member of the Black River Grpup (Hewitt 1968): No typical chocolate brown, Black River. limestone was encountered in the mine area. Rapid: examination of the borehole C.T. 82-14 drilled to test for weathering effects on the talc zone in the area of the East deposit revealed several detrital tourmalines embedded in the bottom portion of the purplish brown Paleozoic rock. These dravite crystals had the same size and appearance as those in the underlying rocks of the Grenville Supergroup. Systematic microscopic examination of Paleozoic rocks overlying the talc deposits may reveal the presence of the detrital talc. 


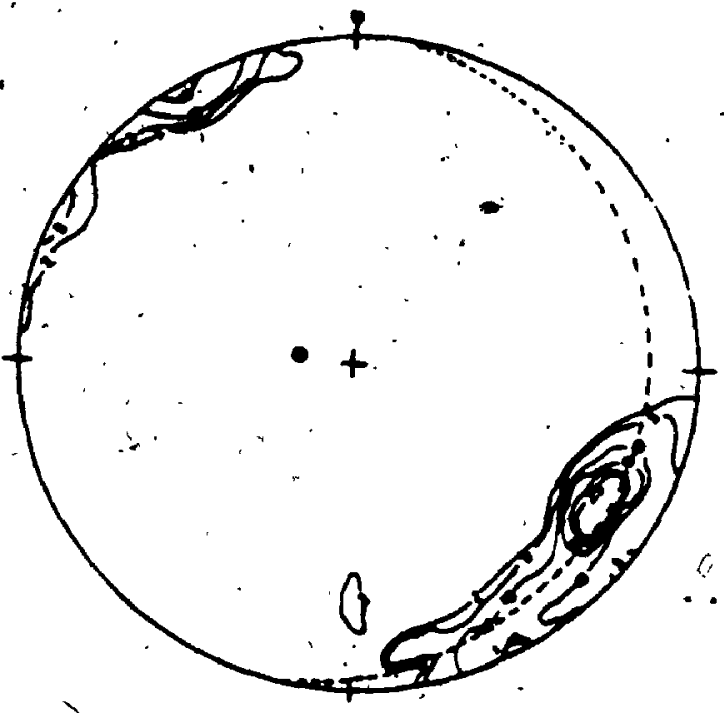

A

$n-41, I^{*}-2,5,10,15,20,25$

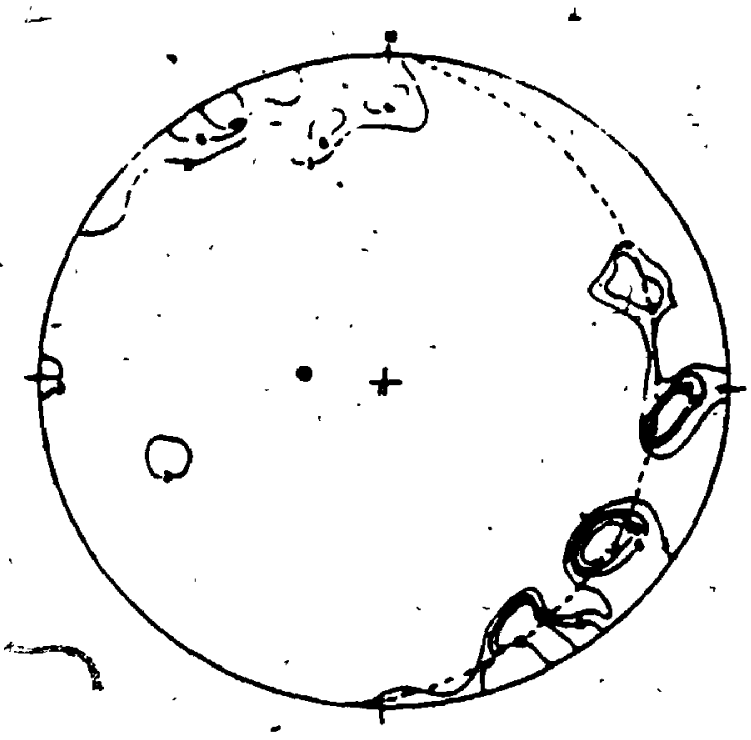

B

$M=30, I-3,6,10,12$

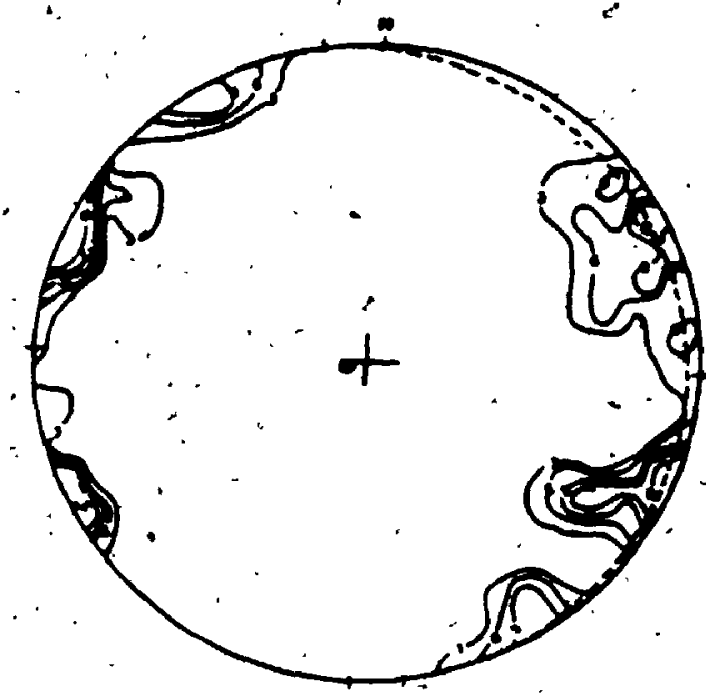

C $N=35,1-3,6,9,12,15$

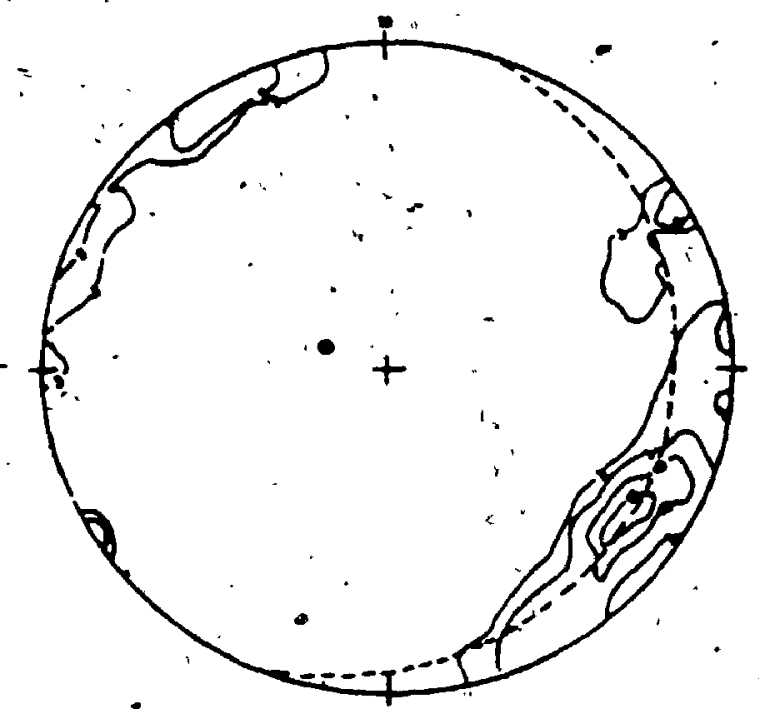

D

F19. 10. - Homogenelty test. Poles of layering from the Henderson Mine area.' Dark dots; represent probable órientation of the fold axis. These orfentations are in agreement with ortentations of fold axes, observed underground and measured by Roscoe (1966). * number of masures. t* contours in 8

A - Henderson deposit (3rd level and decline)

B - New Conley deposit (3rd level)

C - Surface covered by' figure 6

D - Localities $A, B$ and $C$ combined 


\subsubsection{Pleistocene deposits}

Pleistocene unconsolidated deposits cover most of the lowland in the mine area. They consist of boulder and kame moraine (Hewitt 1968) and were studied in the mine area by Sandomirsky (1954). The orientation of glacial fluting and glacial striae varies from $N 25^{\circ} \mathrm{E}$ to N $30^{\circ} \mathrm{E}$ (Sandomirsky 1954 ).

\subsection{Structural Geology}

The structural. geology in the Henderson mine area is complex due in part to imultipłe-phase deformation. Small outcrop area, poor outcrop distribution and ductile rocks make structural interpretation difficult. The general trend of bedding in mine area is $042^{\circ}$ and dip is about $85^{\circ} \mathrm{S}$

\subsubsection{Folding}

Three phases of ductile deformation were identified in the Madoc area by Thompson (1972). He'recognized'first phase $\left(D_{1}\right)$ isoclinal folding, second phase $\left(\mathrm{D}_{2}\right)$ deformation about axial surfaces with northeast orientation and third phase $\left(D_{3}\right)$ open folds with'northwest oriented axials surfaces (Moore and Thompson 1980). The folds reported. from Henterson underground excavations are steeply plunging towards NW and. strike of their axial fold planes was estimated at $\mathrm{N} 60^{\circ} \mathrm{W}$ (Roscoe 1966).

The pales of layering from the third (541 foot) leyel of Henderson deposit (Fig, 10j), "3rd level of New Conley deposit (Fig. 10b) and from the surface (Fig. IOC) are distributed along the great circles. Figures 10a, 10b, and, 10c are combined in Fig. 10d. The orientation of the fold 
axes from these figures supports observations of Roscoe $(1,966)$. The foids described by Roscoe (1966) are probably related to third phase $\left(D_{3}\right)$ deformation described by Moore and Thompson (1980). The folds related to $D_{2}$ and $D_{1}$ deformations were established by tracing selected lithological markers and from the orientation of the layering in marbles.

-4.3.2 Faulting

Wilson (1926), Hewitt 1957), Sandomirsky (1954) and Roscoe (1966) refer to major faults in the presently inaccessible portion of the underground workings. Hewitt (1968, p. 17) states:

"Thęre is a considerable amount of faulting, al though the fault pattern has not been worked out. Wilson (1926) notes that, on the fourth level of the Henderson mine, the talc orebody is cut by an overthrust fault about 50 feet west of the No. 2 shaft. This fault strikes roughly east-west and dips about $45^{\circ}$ to $50^{\circ}$ north. On the fourth. level, there is an apparent horizontal displacement of about 50 feet. This displacement is reported to fade out toward the surface into an open fold. This fault zone also appears on the fifth and sixth levels of the Henderson mine. What may be a substary fault, striking somewhat south of west and dipping vertically, can be seen just north of the ore zone on the seventh level of the Henderson mine. Zones of faulting are also seen in the Henderson Conley crosscut and in the Conley. workings at No. 3 shaft, but. no data on these faults are available."

- No major measurable displacement (over $10 \mathrm{~m}$ ) was observed in the accessible workings. Several minor faults with apparent vertical displacement of less than $2 \mathrm{~m}$ cut the beds of host rock near the Henderson deposit (most of them show less than $1 \mathrm{~m}$ apparent displacement). Important fractures, some of which may be traced up to 40 metres were observed underground. One of these major fractures is exposed on the ramp and twice on the 541.65 foot level of New Conley deposit (Fig. 11 in pocket). This fracture is parallel to the bedding. 


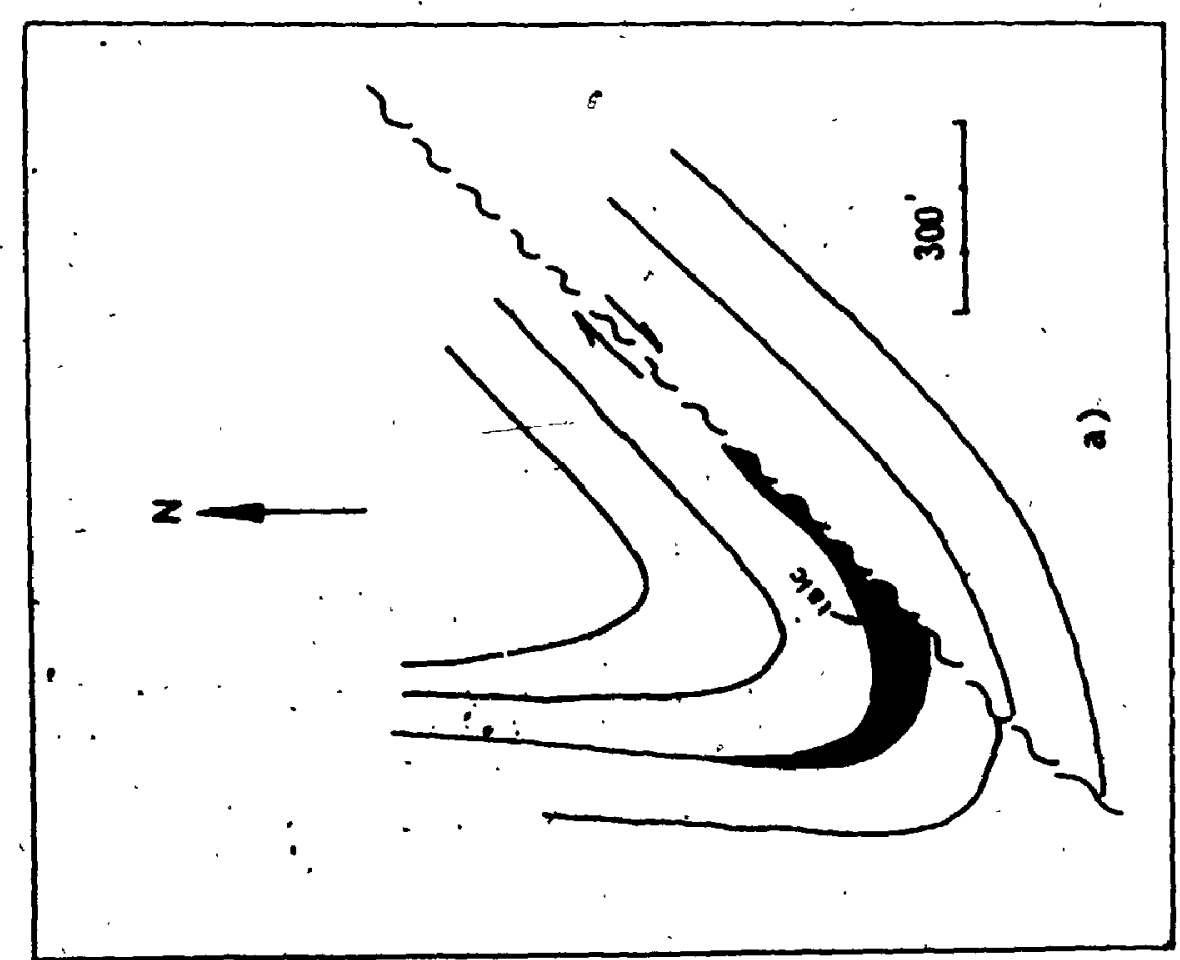

-

$\stackrel{9}{\Sigma}$

5

$\stackrel{1}{2}$

葶

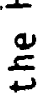

E

ํํㅇ

동응

$N=$

$\frac{U}{\circ}$

$\leftarrow$ u

뭉우

ำ

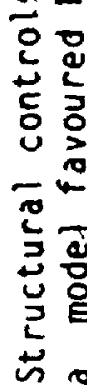

$\therefore$

N

in 
It is filled by smoky euhedral calcite crystals covered by marcasite. Horizontal and vertical lineations are observed in soft gouge along this fracture; however, the sense of the movement is ampossible to determine.

Drill logs from Canada Talc's archives indicate presence of the waterfilled fracture zone in the footwall of the Henderson deposits. This fracture zone is confiamed by in old borehole drilled horizontally from the 541 level which leaks water under considerable pressure and could not be sealed. Borehole'C.T. 82-4 (Fig. 6) intersects a strongly altered zone (near the surface) which may be part of the waterfilled, underground zone. This altered, water bearing zone may be in fact a fault (Fig. 12) of unknown displacement. postulated by Roscoe (1966), and shown by Bain (1960), or it may be a surface of detachment produced during folding.

4.3.3 Structural control of talc deposits.

The northwestern extensions of the Henderson talc deposit are Conley-and East deposit's. The stratigraphic control in the area of East deposit was established by drifting and core logging. Individual talc "u deposits are probably separated by steeply plunging folds which may grade into faults (Fig. 6).

- The southeastern extremity of the Henderson deposit was betieved to correspond to the nose of major fold (Wilson 1926, Sandomirsky 1954, Roscoe 1966); howeyer, no satisfactory interpretation (in form of map) was,previously published. This is probably because early workers did not recognize effects of miltiple phase deformation. 
52

The most satisfactory interpretation based on the information collected by the author up to March 1982 involves multiple-phase folding. and faulting (Fig. 6). Additional drilling or trenching would be necessary to confirm the validity of the structural information presented in Figure 6.

$\therefore$ Detailed mapping of the new open cast excavation of the. East deposit may. shed more light on the type of folding or faulting. separating the East deposit, from the Con Fey deposit.

Detailed geological mapping of the underground excavations of the New Conley deposit is necessary to establish if talc deposits in the vicinity of No. 3 shaft are related to the main talc horizon.

* Isoclinal fold (fig. 6) has, major stratigraphic implication. Isoclinal folds of the Madoc area occur in pre-flinton rocks only (Moore 1984, personal communication). 
CHAPTER 5: HENDERSON AND RELATED TALC DEPOSITS

Talc occurs in several geological environments in the map area (Fig. 6). These occurrences may be subdivided into Henderson type deposits (Henderson, Conley and East deposits), New Conley deposit and other talc occurrences. Only the Henderson type deposits are described in detail.

\footnotetext{
Hendeyson type deposits were and still are economically the most important. Their history was summarized in the introduction.
} Henderson type deposițs are sheet or lens-like bodies corresponding to the widest known sections of the main talc horizon (Fig. 6). None of these deposits outcrop in the area. The extent of the Main talc horizon is known from isolated outcrops, underground workings, and 1981-1982 diamond drilling (see boreholes CT-81-3, CT-81-4, CT-81-7, ${ }^{\circ} \mathrm{CT}-81-9, \mathrm{CT}-81-10$ and $\mathrm{CT}-82-1, \mathrm{CT}-82-4 ; \mathrm{CT}-82-5, \mathrm{CT}-82-8$ of Fig. 6). The talc horizon is interrupted and displaced by folding and/or faulting, complicating interpretation and exploration. The thickness of the talc varies from a few centimetres to over $30 \mathrm{~m}$.

7.1. Henderson Deposit

The Henderson deposit did not originally outcrop, but at present it is exposed by extensive overburden stripping. Open pit and underground.workings of the Henderson deposit are no longer accessible except for a portion of the 541 foot levej and decline which are connected to No. 3 shaft.(Fig. 2). 


\subsubsection{Morphology and structure}

$\because$ The Henderșon deposit is a tabular sheet. It is over $250 \mathrm{~m}$ long, 7 to $25 \mathrm{~m}$ thick, at least $250 \mathrm{~m}$, deep and open at depth (Fig. I3). It strikes $\mathrm{N} 42 \mathrm{E}$ and dips $65^{\circ}$ to $85^{\circ} \mathrm{NW}$. The strike changes abruptly to the northwest at the western extremity of the deposit where it may be terminated by à fold and/or fault (Fig. 6).

The eastern extremity of the Henderson deposit is probably separated from the Conley deposit by a steeply. plunging fold grading to a fault (Fig. 6). Several amphibolite dykes and mica, sulphide and -tourmaline veins cut the deposit. However, no direct talc-dyke relationship is observed. Near the surface the deposit is truncated by. an unconformity and. covered by Paleozaic rocks and unconsolidated pleistocene deposits. "Detailed morphology fof the deposit is given in the Appendix 'IV.

\section{1 .2 Lithol ogy}

Talc rjch rocks of the Henderson deposit may be subdivided into two major types:

1) coarse; flaky; talc bearing rock

2.) steatite (massive, aphanftic to fine grained, talc bearing rock)*.

Coarse, flaky talc-bearing rock, is-characterized by snow-white to light green flakes (from 0.5 to. $2 \mathrm{~cm}$ across) of talc. No banding. laminations or other remnanf sedimentary textures could be observed macroscopicaliy or microscopically, except for a few concordant.

* These rocks are excellent tatc ores (coarse flaky talc-bearing.rock is the highest grade ore). 
$\gamma$

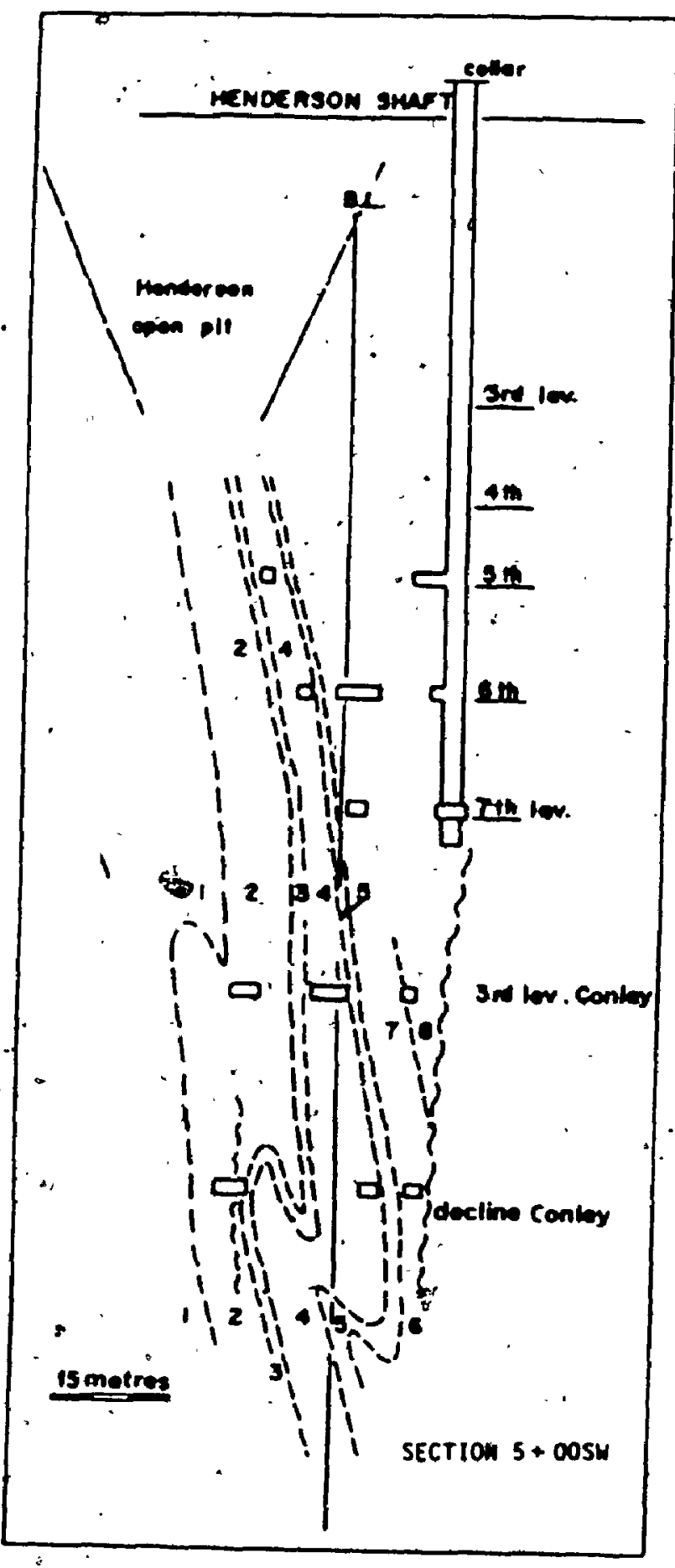

Fig: 13 - Typical vertical section through Henderson deposit (for location "see Appendix IV).

1: Phyllite

2. Tremolitic micaceous dolomitic marble

3. "Lean" isteatite

4. Coarse, flaky talc rock and steatite

5. Tremolitic, micaceous marble

6. Quartzite with stromatolitic texture

7. "Mottled-blue" dol omite

8. Unidifferentiated dolomite 


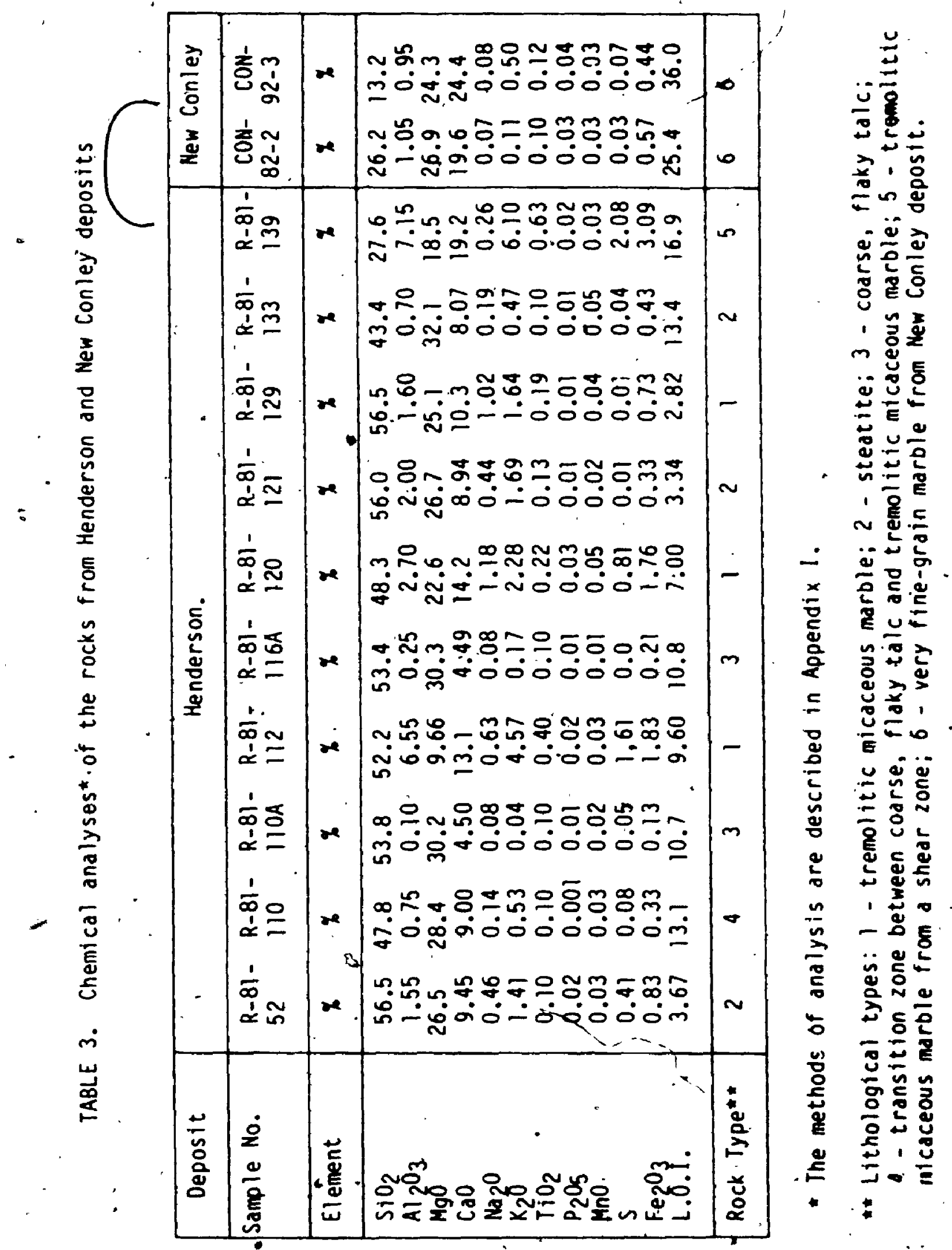


tourm line bearing layers, or siliceous layers which are of uncerfain or Igin.

The coarse, flaky tale bearing rock is comprised of talc (90\%), dolomite $(-5 x)$, calcite ( $-1 x)$, tremolite $(-5 x)$, serpentine $(-2 x)$ and infce (-2X) (samples R-81-110A and R-81-116A, Appendix III). Undeformed Crystals of dravite form local concordarit bands:

Dolomite coated by talc, corroded islands of dolomt te and tremolite enclosed in talc mass and pseudomorphs of talc after tremolite suggeșt that the coarse. flaky talc-bearing rock was formed by replacement of tremolite and carbonate (dolomite and poșsibly magnesite) by talc. Doiomite t talc and trewojite + talc are observed in contact with each other.

Calcite is not present in the higher grade ore but may be observed in marginal waterials. Chemical analysés of the $R-81-110 A$ and $R-81-116 A$ indicates that $\mathrm{MgO}, \mathrm{SiO}_{2}$ and $\mathrm{CaO}$ are the most abundant major oxides (Table 3). Geochemical data will be treated in detail in the following chapter.

- Steatite is light green, gray, light brown or white. It is hard, compact: aphanitic to fine-grained material, which breaks along conchoidal fractures and cleavages. It may contain very. distinct light gray. white, light green, dark green or brown laminations and bands. The green colour is related to the presence of serpentine. Some of the gray colour variations are concentrations of opaque minerals (Plate 9 to Individala fainations way bé traced up to 10 metres and are highly contorted. These laninations way be pritiary sedimentary features, because they are paralleft to bedding and even groscbedding was found in - block of this unterial. 
Steatite is comprised of talc, dolomite, tremolite, serpentine with or without calcite, sulphides and mica in various proportions (s amp les $R-81-116 B, R-81-116 C, R-81-1160, R-81-121, R-81-133$, see

Appendix IIi). Mnerals in contact with each other are: talc-dolomite, talc-dolomite-serpentine, tremolite-talc and possibly.

talc-tremolite-quartz. The chemical composition of samples (R-8)-52. $R-81-121$ and $R-81-1-33$ ) are given in Table 3 .

The two types of talc bearing rocks (coarse, flaky talc and stestite) grade into each other over a distance of less than 1 metre. The proportion of these two types of rock in the Hènderson deposit is about 1:1 (Roscoe 1966). Although usually surrounded by steatite, the coarse, flaky talc, rocks may grade directiy joto tremolitic micaceous marble. Steatite may contain zones of only partiy. steatized dolomite.

5.1.3. Characteristics of talc product

Mineralogical, chemicai and physical properties of the average mill run (product) differ from those of coarse, flaky ore. Samples of aill run include not only coarse, flaky talc but also steatite and some host rock (tremolitic micaceous marble), which may contain sulphides. Typical mineralogical, chemical and physical properties af mined ana milled materials are given in Tables 4,5 and 6 .

\subsection{Conley Deposit}

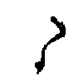

The Conley deposit is located on strike northeast of the Henderson deposit (Fig. 2). 'It does not outcrop and underground workings are no longer accessible. It was never subject to systematic geological mapping. 
TABLE. 4. Quantitative estimates by SEM*/EDXA* on the average mill run from. Henderson deposit (Goldberg and Wehrung 1.981 ).

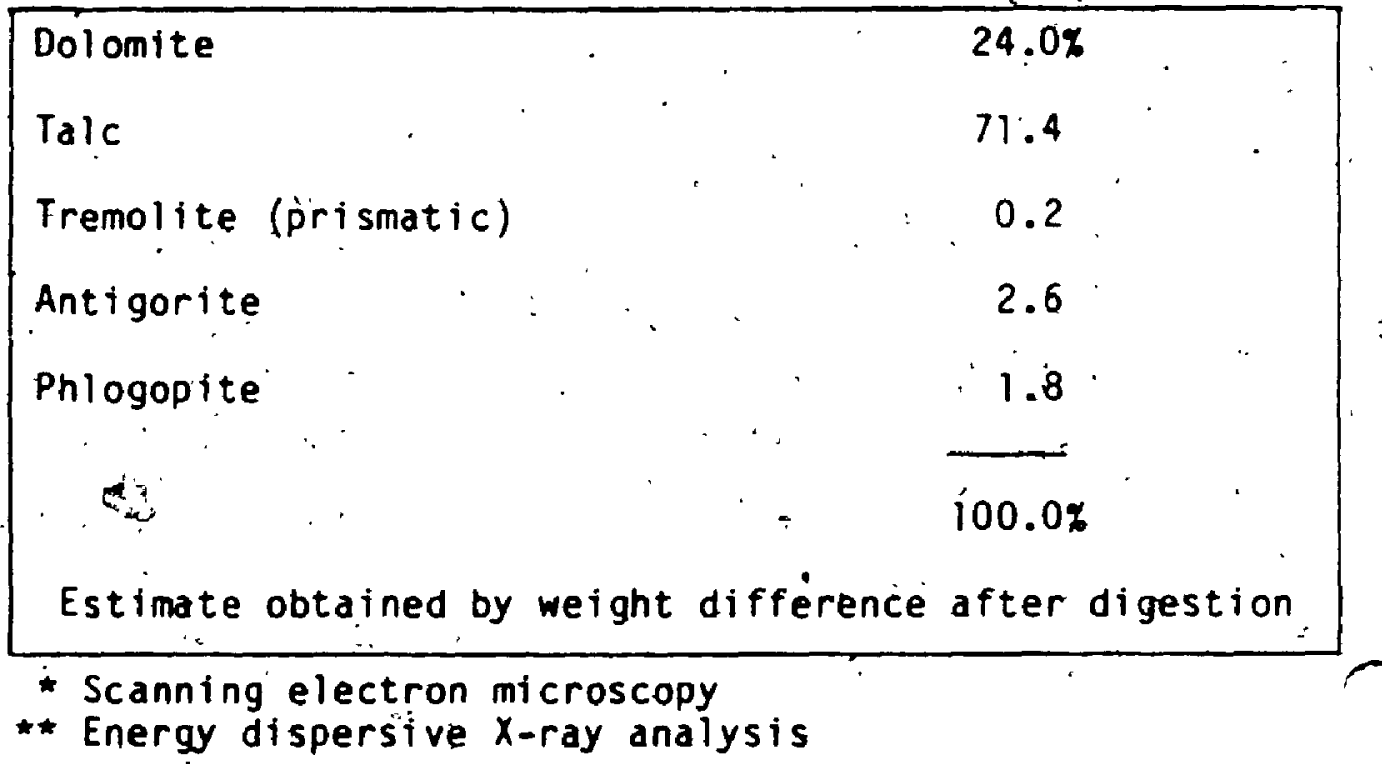

TABLE 5. Typical chemical anglysis of the average mill run from Henderson deposit (Richardson 1981).

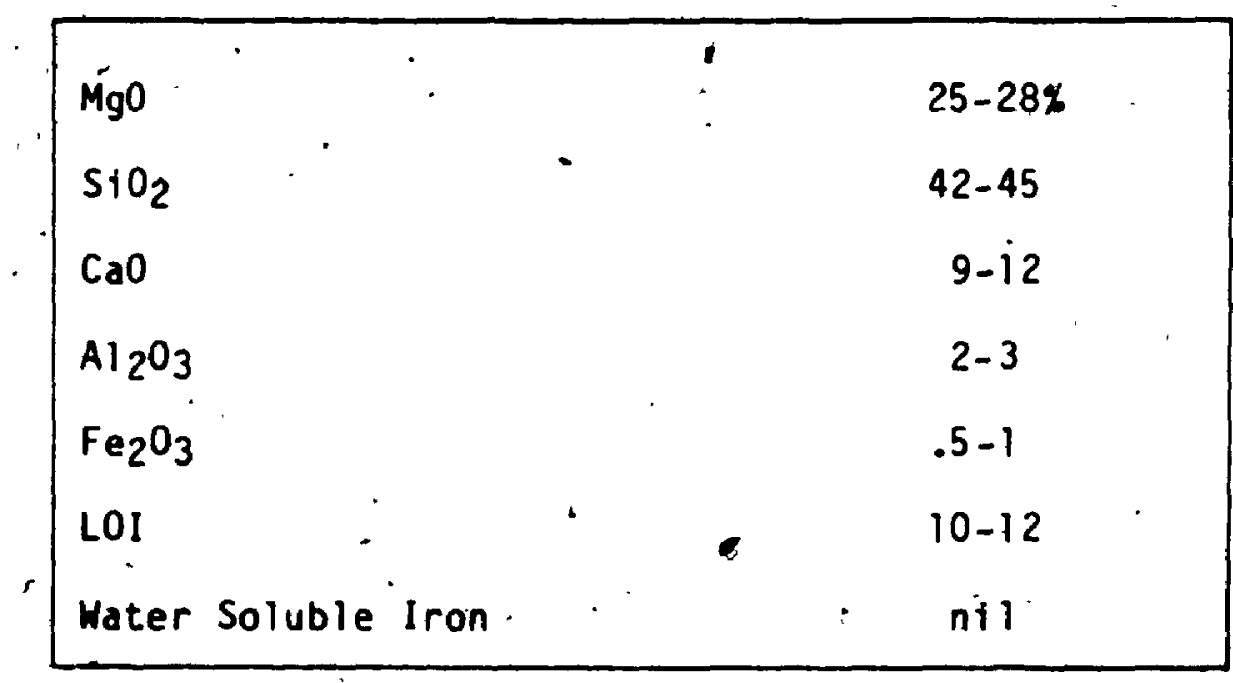


TABLE 6. Average physical characteristics of the coarse, flaky talc-bearing rock and steatite mixture (mill run) from Henderson deposit (compilèd from Ogden 1981).

\begin{tabular}{|l|c|}
\hline Form of the Particles & Platy \\
\hline Colour & Pure white \\
\hline $\begin{array}{l}\text { Brightness of dry ore } \\
\text { (green filter) at } \\
30 \text { mesh }\end{array}$ & $94-95$ \\
\hline $\begin{array}{l}\text { Brightness of dry ore } \\
\text { (green filter) at } \\
-325 \text { mesh }\end{array}$ & $95-96$ \\
\hline $\begin{array}{l}\text { Acid soluble content } \\
\text { in the centrai zone of } \\
\text { the orebody }\end{array}$ & $25-30 \%$ (in form of unusually \\
white dolomite) \\
\hline
\end{tabular}

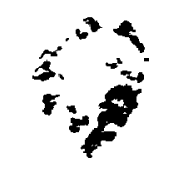




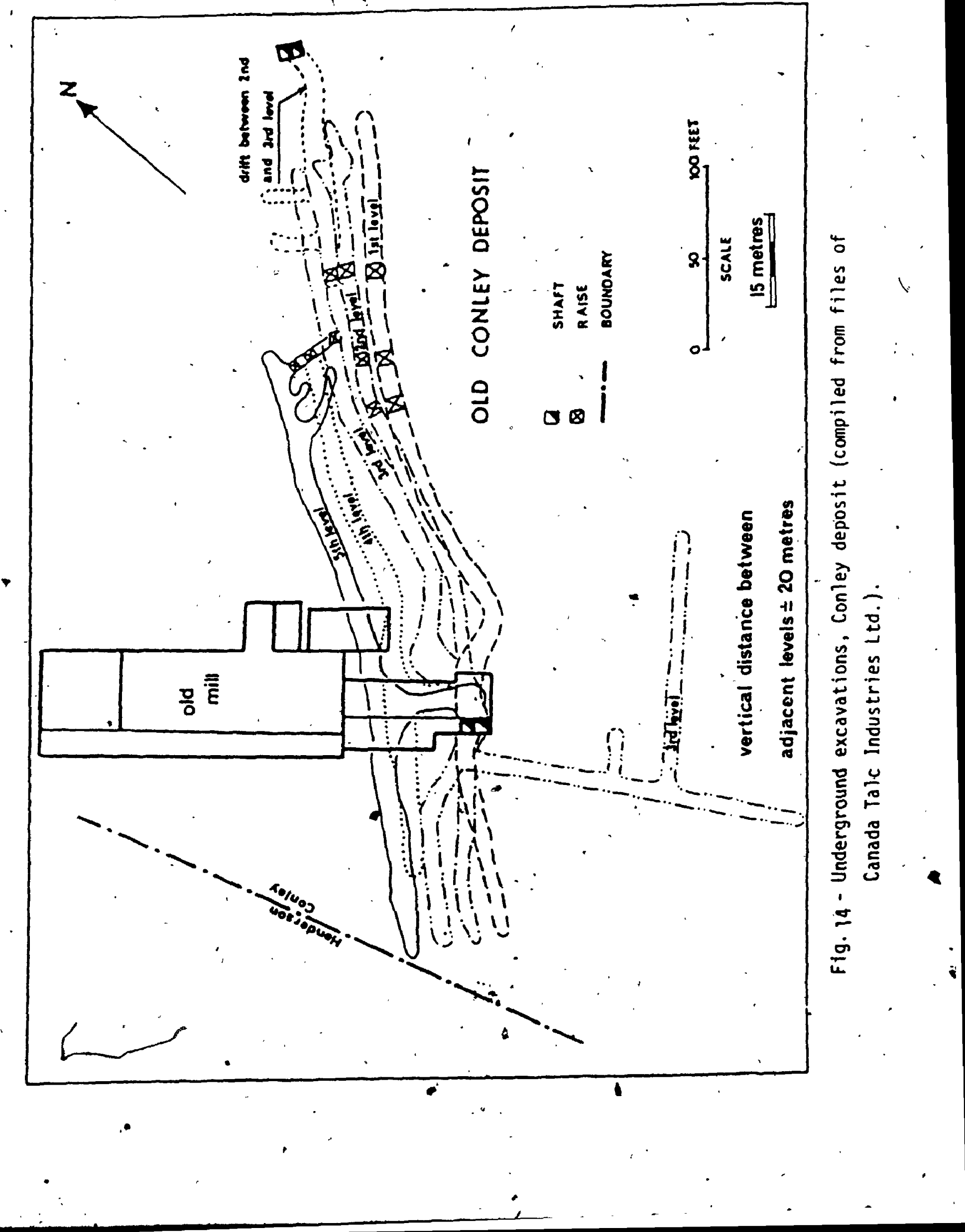




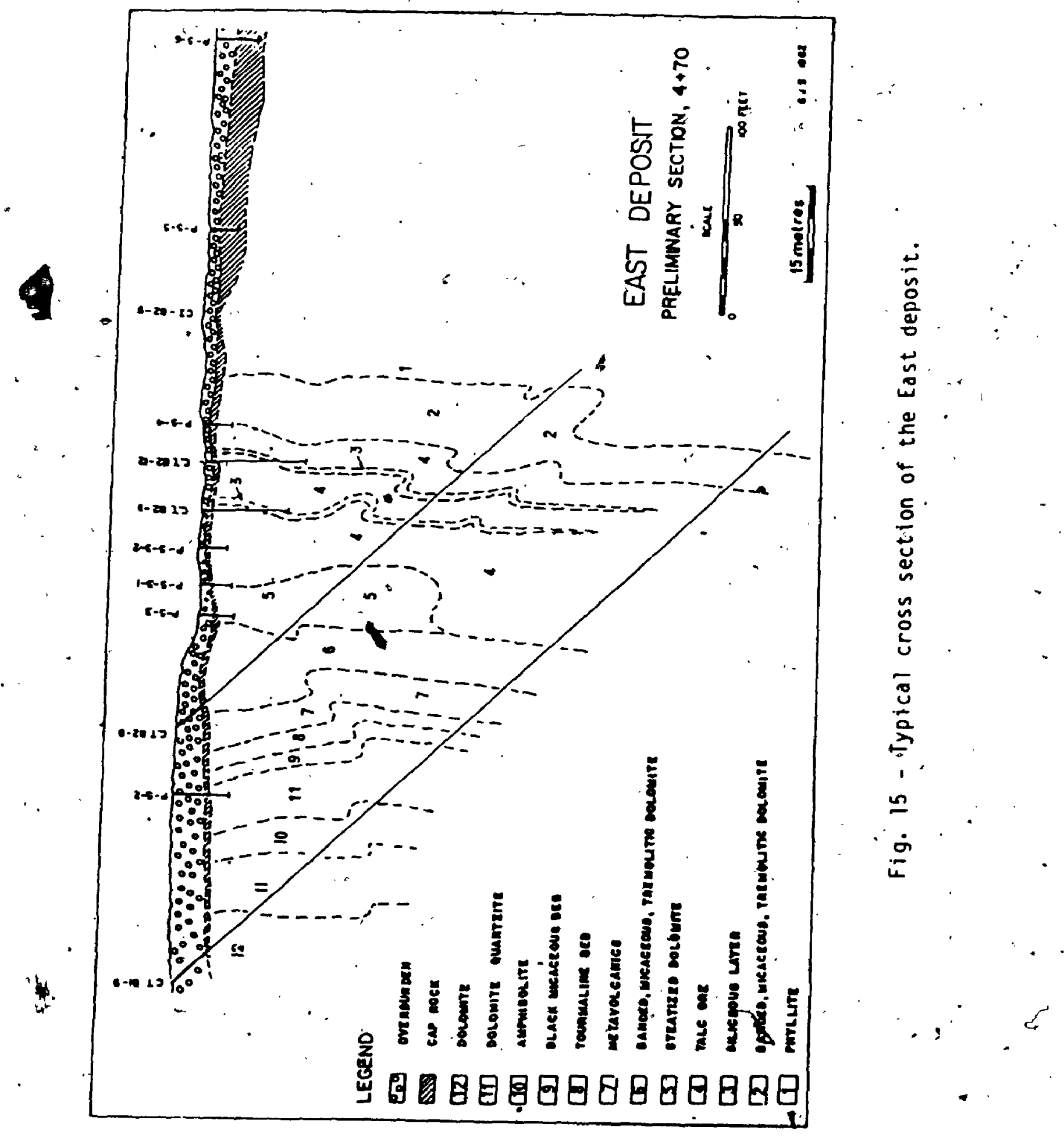




\subsubsection{Morphology and structure}

The underground workings are outlined in Figure 14 . The drifts were excavated in talc (Evans 1926) and.their outline at various levels is an excellent indicator of the strike and dip of the deposit. Dip varies between $75^{\circ}$ and $85^{\circ} \mathrm{N}$. The strike of the deposit is about N45E. The deposit is about $125 \mathrm{~m}$ long and at least $3 \mathrm{~m}$ thick. It is keel-shaped (length decreases with depth). It was cut by several dark dykes (Evans 1926).

\subsubsection{Talc-bearing rocks}

The talc-bearing rock of the Conley deposit is very similar to the taic-bearing rock from the Henderson deposit but of better quality (Sandomirsky 1954). Chemical analysis confirms that the talc ore from Conley deposit is similar to the talc ore from the Henderson deposit. (The difference in $\mathrm{CaO}$ content will be discussed under the topic of geochemistry, Table 10.)

\subsection{East deposit}

The East deposit is located $100 \mathrm{~m}$ from the Henderson deposit (Fig. 2). It is simflar to the Henderson deposit in every respect. It does not outcrop but it was thoroughly investigated by diamond drilling (Fig. 6).

The stratigraphic sequence ("phyllite", banded tremolitic micaceous marble, talc horizon, presence of the tourmaline layers, etc.) suggests that it belongs to the same hortzon as Henderson deposit. 
5.3.1 Morphol ogy,

The deposit is at least $120 \mathrm{~m}$ long and its thickness varies from 5 $m$ to $30 \mathrm{~m}$. Typical crass section of the deposit is shown by figure 15.

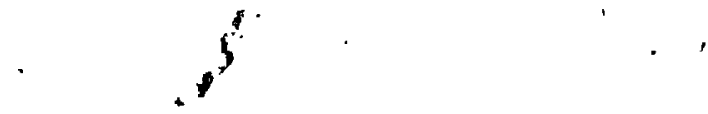

\subsubsection{Talc ore}

The ore consists of coarse, flaky talc-bearing rock and steatite and includes also limited quantities of tremolitic micaceous marble. Coarse, flaky ore consists mainly of talc with rome dolomite, tremolite, calcite, phlogopite, mingr vermiculite, chlorite and quartz (B) ount 1982).

5.4 A brief note about New Conley Deposit

The New Conley talc deposit is located near Conley No. 3 shaft (Fig.-2). The morphology of the deposit is poorly known. The ore is a brittle, fractured white to light green dolomite marble, where talc occurs as fracture fillinns less than $3 \mathrm{~mm}$ thick. Dolomite, tremolite and talc are major. mineral phases, phlogopite and antigorite are minor. mineral phases (Table 7). Calcite was identified by Ltiaining.

A partial chemical analysis of the New Conley ore, supplied by Canada Talc Industries is shown in Table 8 (no other chemical analyses are known). 
TABLE 7. Quantitative estimate of mineral composition by SEM/EDXA on New Conley talc ore (Goldberg and Wehrung, 1981)

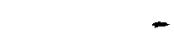

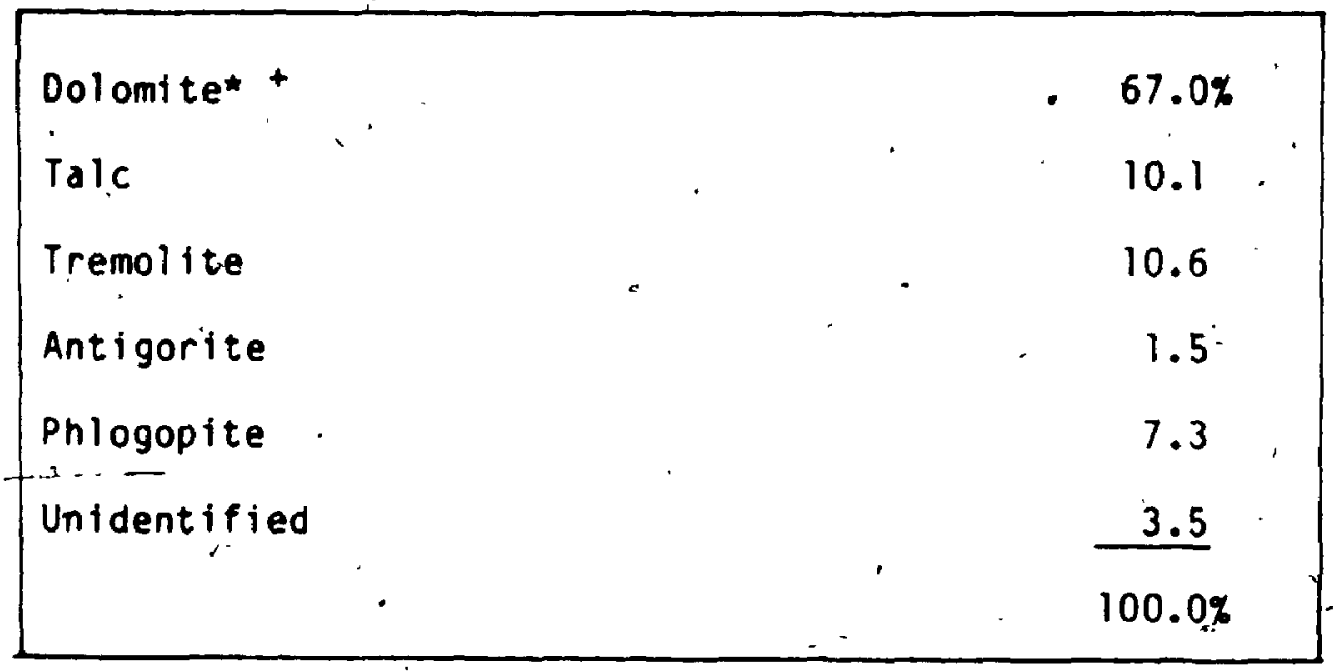

* Estimaţe obtained by weight differençe after digestion (Goldberg and Wehrung, 1981).

+ Calcite was identified by staining of thin sections by

'the author, although it is shown to be absent.

TABLE 8. Typical chemical analysis of New Conley Ore (Dolfill \& Talfill Products*).

\begin{tabular}{|lr|}
\hline Major Oxide & \multicolumn{1}{c|}{ \% Range } \\
\hline $\mathrm{MgO}$ & $20-24$ \\
$\mathrm{SHO}$ & $16-18$ \\
$\mathrm{CaO}_{2}^{\circ}$ & $26-30$ \\
$\mathrm{Al}_{2} \mathrm{O}_{3}$ & $0.5-1$ \\
$\mathrm{Fe}_{2} \mathrm{O}_{3}$ & $0.5-1$ \\
$\mathrm{LOI}$ & $30-35$ \\
\hline
\end{tabular}

- Commercial names 
CHAPTER 6: GEOCHEMISTRY OF THE ROCKS FROM HENDERSON AND NEW CONLEY DEPOSITS

\subsection{Description of samples from Henderson and New Conley deposits}

Ten samples from the Henderson deposit and two samples from the New Conley deposit were analyzed for major elements (Table 3). The samples àre briefly described below (see Appendix III for detailed descriptions). The methods of analysis are described in the Appendix I. Sample localities are shown in Figure 16.

a) Lithology of samples from Henderson deposit

Samples $R-81-110 A$ and $R-81-116 A$ represent coarse, white and flaky talc. Samples $R-81-52, R-81-121$ and $R-81-133$ correspond to steatite. Samples $R-81-120, R-81-129$ represent typical tremolitic, micaceous marble. Sample R-81-112 is a coarse tremolitic marble that appears unaltered and contains an above average amount of quartz as laminations. Sample R-81-139 is also tremolitic micaceous dolomite but it was located in a shear zone. It contains more calcite and amber mica than the typical tremolitic, micaceous talc-bearing marble.

b) Lithology of samples from New Conley deposit

- Fine-grained marbles (samples CON-82-2 and CON-82-3) are macroscopically and texturally similar to steatite from the Henderson deposit. However, their chemical composition is characterized by lower $\mathrm{SiO}_{2}$ and higher $\mathrm{MgO}$ and $\mathrm{CaO}$ concentrations (Table 3 ). 


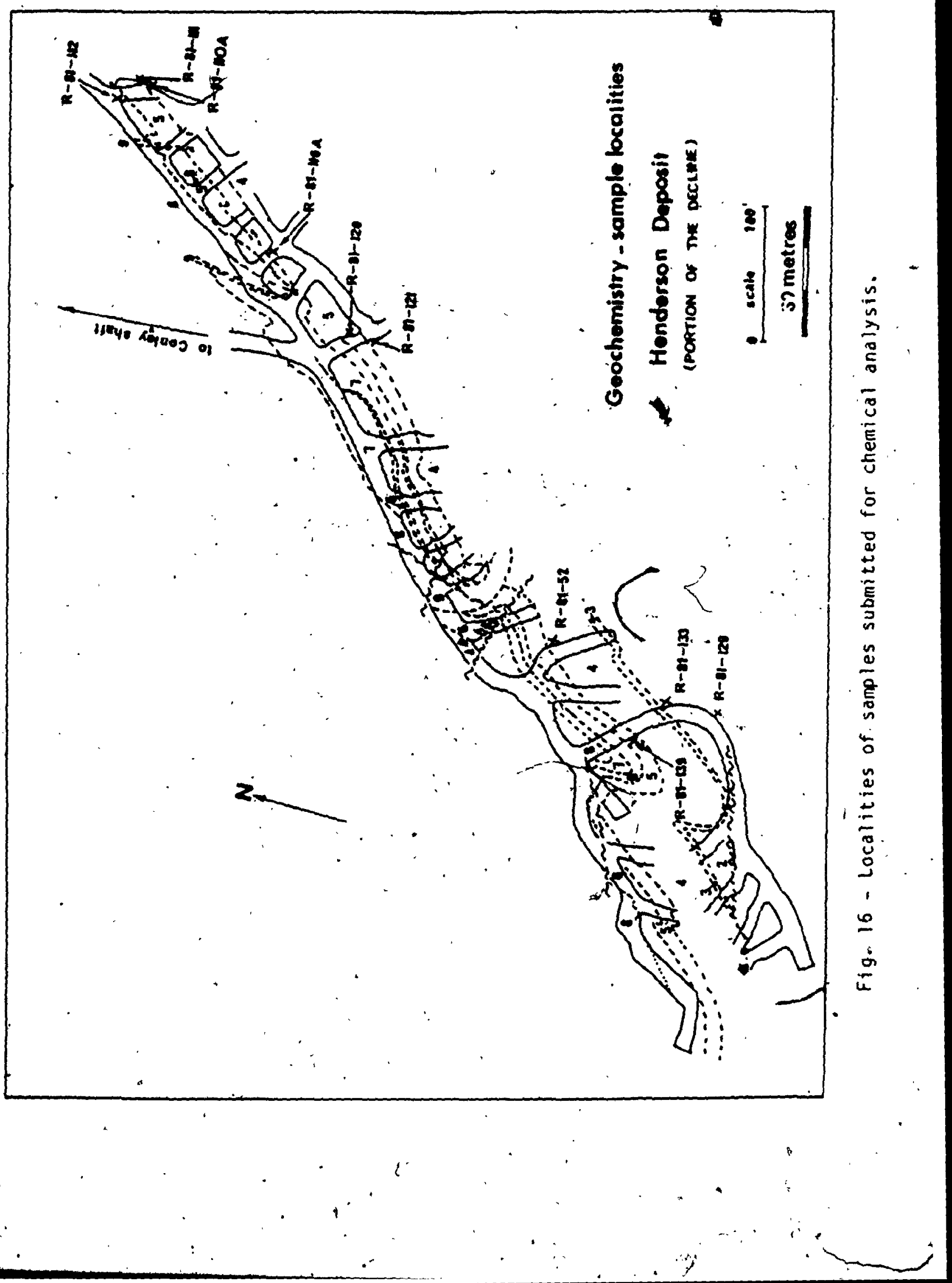




\subsection{Chemical composition of Henderson deposit and its host rock}

Composition of the main talc-bearing rock types and adjacent

tremolitic mticaceous marble from the Henderson deposit are summarized in Table 9 .

\section{$6.3 \mathrm{MgO} / \mathrm{CaO}$ ratio}

The MgO/CaO ratios in coarse talc-bearing rocks and steatite are. higher than in average tremolitic micaceous marble (Table 10). Although some specimens ( $\mathrm{CON}-82-2, \operatorname{CON}-82-3)$ from the New Conley have textures identical to steatite, their MgO/CaO ratios are lower (Table 11). Most of the $\mathrm{MgO} / \mathrm{CaO}$ ratios from the Henderson deposit (Table 10) are higher than that of a theoretical dolomite. High MgO/CaO ratios suggest that. if the talc deposit was formed in a chemically closed system.then an appreciable amount "magnesite was required within the dolomite rock. On the other hand if the system was chemically open during the talc forming process and original rock was siliceousvolomite, then either MgO may have, been added to the sfytem, $\mathrm{CaO}$ may have been leached from the system, or addition of $\mathrm{MgO}$ and leaching out of $\mathrm{CaO}$ may have taken place.

An inverse, linear relationship exists between MgO increase and CaO decrease in all the samples of the Henderson deposit except sample R-81-139, which corresponds to thin shear zone (Fig. 17).

\section{$6.4 \mathrm{SiO}_{2}-\mathrm{CaO}-\mathrm{MgO}$ diagram}

$\mathrm{SiO}_{2}$, MgO and $\mathrm{CaO}$ are the most abundant components of the talc-bearing rocks of the Henderson deposit (Table 3). An $\mathrm{SiO}_{2}-\mathrm{MgO}_{\mathrm{C}} \mathrm{CaO}$. diagram (Fig. 18) is the most convenient plot to compare the chemistry 


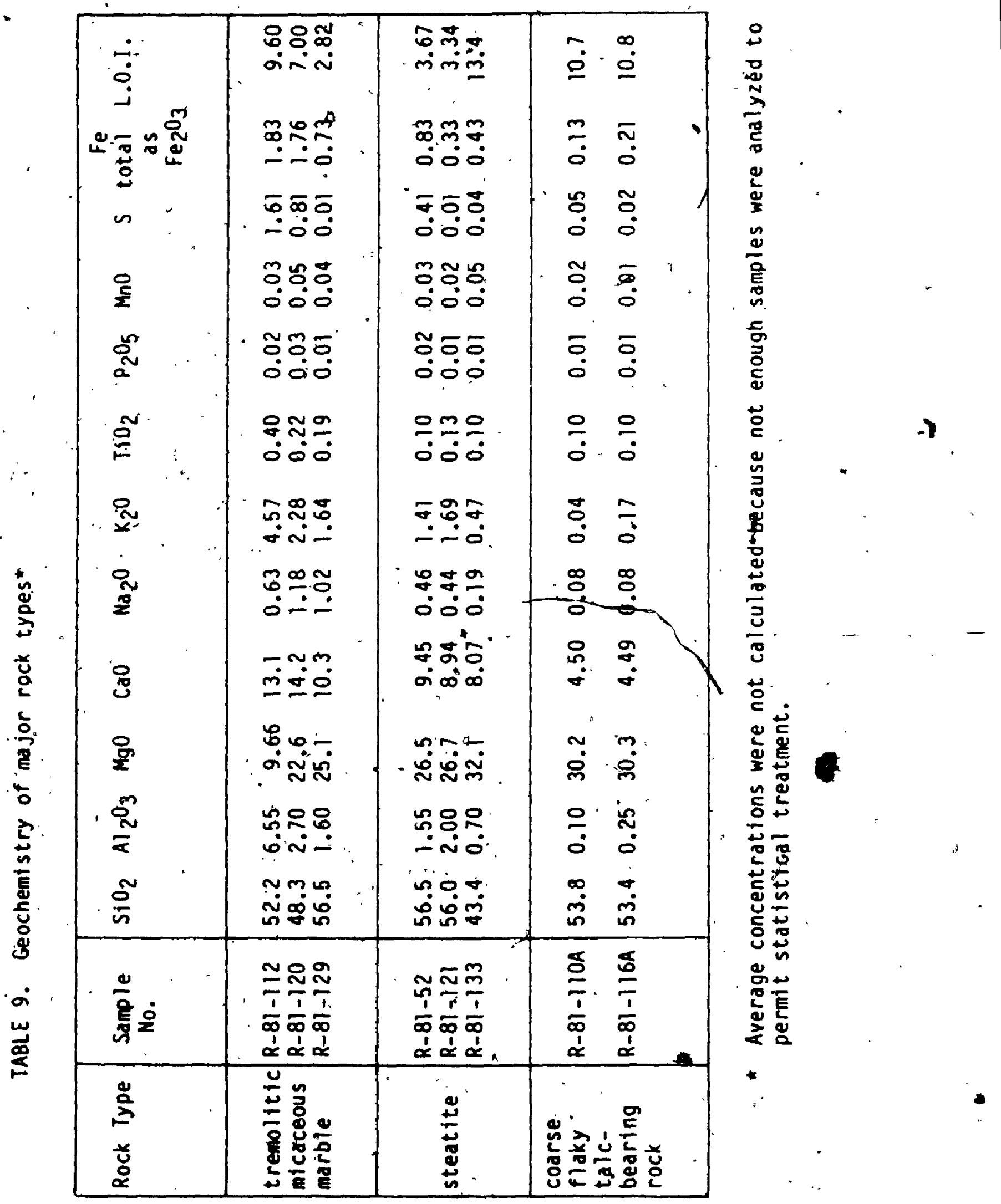


TABLE 10. MgO/CaO Ratios of samples from Henderson deposit

\begin{tabular}{|l|c|c|}
\hline Sample No. & MgQ/Ca0 ratio & rock type \\
\hline$R-81-52$ & 2.8 & steatite \\
\hline$R-81-110$ & 3.2 & steatite \\
\hline$R-81-110 A$ & 6.7 & coarse flaky. talc \\
\hline$R-81-112$ & 0.7 & $\begin{array}{c}\text { tremolitic, micaceous, dolomitic } \\
\text { marble }\end{array}$ \\
\hline$R-81-116 A$ & 6.7 & coarse flaky talc \\
\hline$R-81-120$ & 1.6 & $\begin{array}{c}\text { tremolitic, micdceous, dolomitic } \\
\text { marble }\end{array}$ \\
\hline$R-81-121$ & 3.0 & steatite \\
\hline$R-81-129$ & 2.4 & $\begin{array}{c}\text { tremolitic, micaceous, dolomitic } \\
\text { marble }\end{array}$ \\
\hline$R-81-133$ & 4.0 & steatite \\
\hline$R-81-139$ & 1.0 & shear zone \\
\hline
\end{tabular}

*Detailed mineralogical descriptions are given in the Appendix III.

TABLE 1.1. MgO/CaO Ratios of samples from New Conley 341 foot-level) drift.

\begin{tabular}{|c|c|c|}
\hline Sample No. & $\begin{array}{c}\text { MgO/CaO } \\
\text { Ratio }\end{array}$ & Rock Type \\
\hline CON-82-2 & 1.3 & aphanitic serpentinized marble \\
\hline CON-82-3 & 0.9 & aphanitic serpentinized marble \\
\hline
\end{tabular}

- Detailed mineralogic descriptions are given in the Appendix 14 . 


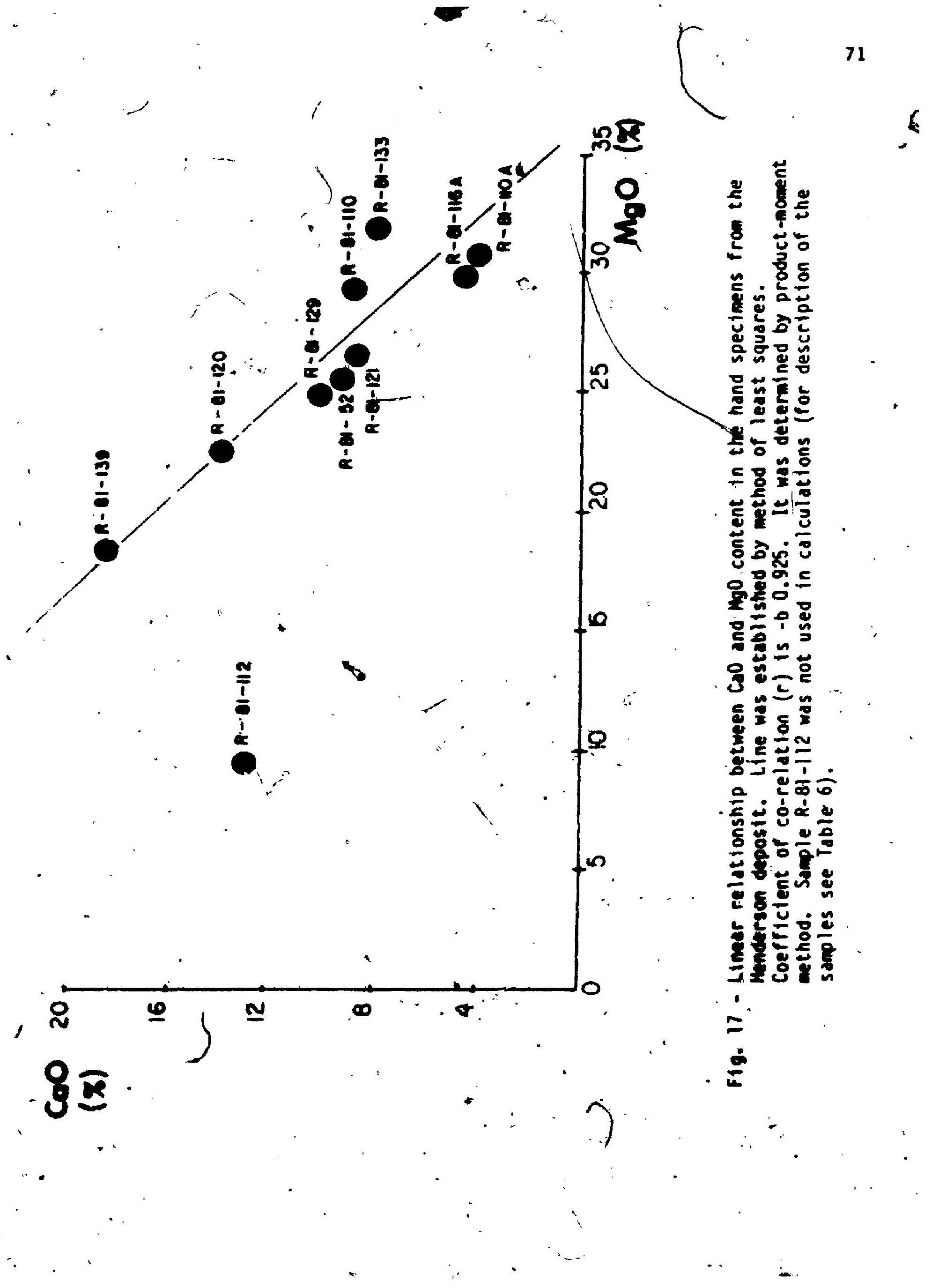




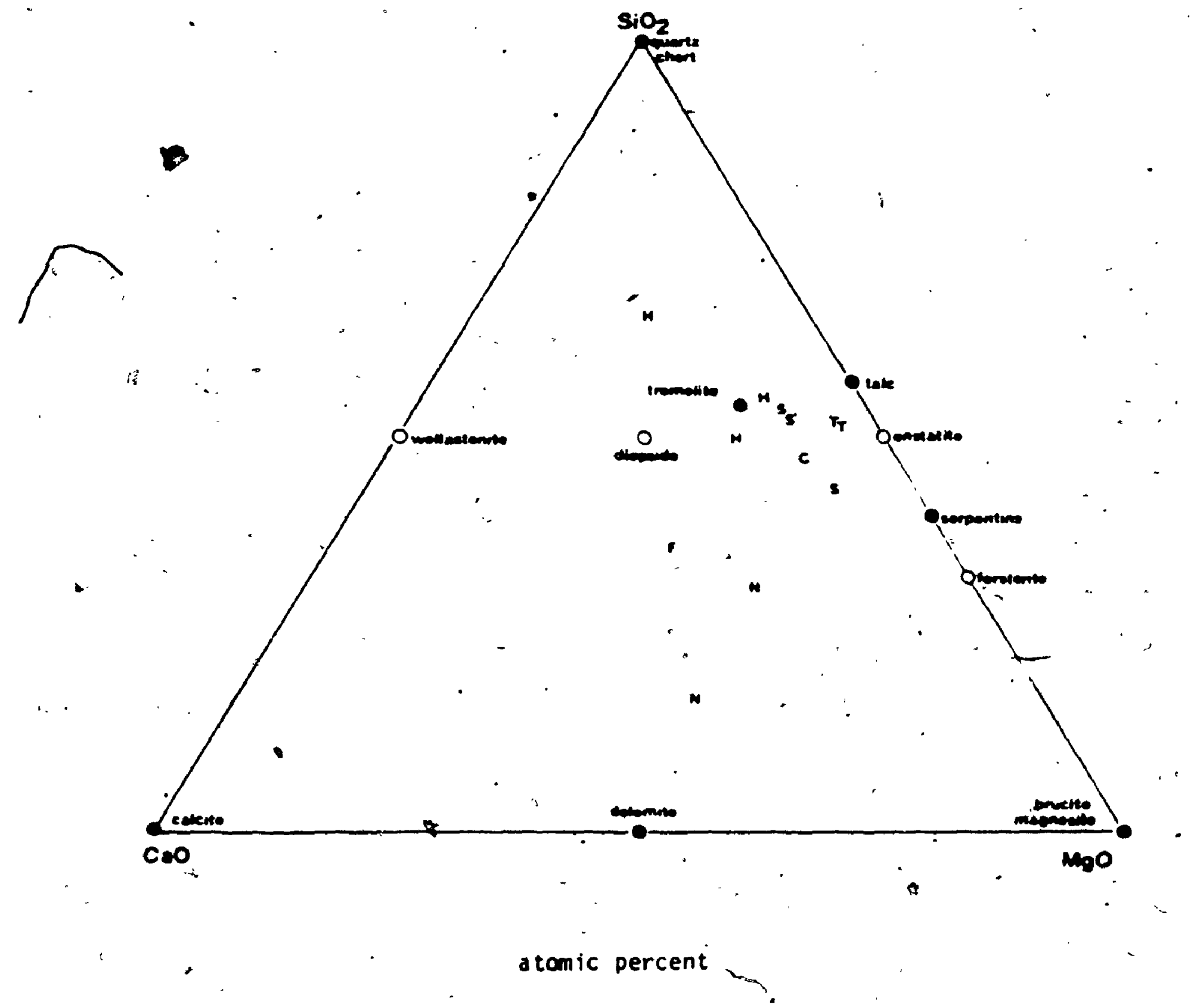

Ftg. $18 \mathrm{StO}_{2}-\mathrm{CaO}-\mathrm{MgO}$ diagram. of rocks from Henderson and - New Conley deposits.

Symbols: T - coacse Haky talc-bearing rock; S - steatite: $H$ - tremolitic atcaceous marble; $C$ - transition zone between coarse. fleky talc-bearing rock and tresolitic alcaceous wrble: F - tremolitic at caceous arble from a shear. zone; N -. Mew Conley' marble encroscoptedily stafler to teatte. 
of coarse, talc specimens, steatite. and tremolitic micaceous marble. It permits also convenient comparison of the chemical composition of the above described rocks with the chemistry of the theoretical talc.

Typical samples of the coarse flaky talc-becing rock, steatite and tremolitic micaceous marble have similar proportions of $\mathrm{SiO}_{2}$, MgO and CaO (Fig. 18). CaO conceatrations are highest in the tremolitic micaceous marble and lowest in coarse, flaky talc-bearing rock.

Steatite has intermediate $\mathrm{SiO}_{2}-\mathrm{MgO}-\mathrm{CaO}$ proportions except the sample R-81-133. This deviation from normal is related to unusually high serpentine content of the rock.

Coarse, flaky talc-bearing rock is charactertized by lower Ca0 concentrations than steatite and micaceous tremolitic marble. However, a micaceous tremolitic marble from a shear zone is impoverished in $\mathrm{SjO}_{2}$ and enriched in CaO in relation to typical tremolitic micaceous marble.

Contact zone (c) between coarse, flaky talc-bearing rock and tremolitic micaceous marble (ample R-81-110 of fig. 18) has higher CaO arid luwer siu propostions than the coarse, flaky talc specimens, but higher $\mathrm{Sin}_{2}$ and lower $\mathrm{CaO}$ content than tremolitic micaceous marble. çoarse, flaky talczbearing rock and steatite are substantially different from theoretical talc*: The difference is caused by the presence of various accessory minerals dolomite, tremolite, mica, serpentine even in the best coarse, flaky talc-bearing samples.

Samples from the New Conley deposit (CON-82-2 and CON-82-3) have very low $\mathrm{Sill}_{2}$ concentrations if compared with the rocks of the Hendersun deposit.

(ialculated composition of therretical (stoichio 19/5). 


\subsection{Chemical zoning across the Henderson deposit}

Results of chemical analysis of the-talc-bearing rocks (coarse. flaky talc-bearing rock, steatite and tremolitic micaceous marble-coarse, flaky talc-bearing rock contact) as well as host rock, (tremolitic mfcaceous marble) are plotted along the idealized geological cross section (Fig. 19).

$\mathrm{SiO}_{2}$ content is variable and does hat follow any clear cut trend. $\mathrm{Al}_{2} \mathrm{O}_{3}$ is least abundant in the coarse, flaky talc-bearing rock and increases outward. Highest concentrations correspond to the tremolitic-micaceous marble specimens. $\mathrm{CaO}, \mathrm{Na}_{2} \mathrm{O}, \mathrm{R}_{2} \mathrm{O}, \mathrm{TiO}_{2}, \mathrm{MnO}, \mathrm{Fe}$. (as $\mathrm{Fe}_{2} \mathrm{O}_{3}$ ) and possibly $\mathrm{S}$ follow the same trend as $\mathrm{Al}_{2} \mathrm{O}_{3}$. Variations in loss on ignition (L.0.1.) trend cannot be easily interpreted. Shear zonẹs have a very distinct chemical character from the tremolitic - micaceous.marble. They contain less $\mathrm{SiO}_{2}, \mathrm{Na}_{2} \mathrm{O}$, and more $\mathrm{Al}_{2} \mathrm{O}_{3}, \mathrm{CaO}$, $\mathrm{K}_{2} \mathrm{O}, \mathrm{TiO}_{2}, \mathrm{~S}, \mathrm{Fe}\left(\mathrm{Ss}_{2} \mathrm{Fe}_{3}\right)$. L.O.l. of the shear zone is also higher than than of tremolitic micaceous dolomite.

6.6 Chemistry of talc ore and host rock from Henderson deposit
compared to other talc occurrences in carbonate rocks in North America.

The distinction between chemical analysis of the hand specimens and chemical analysis of "mill run" is necessary to interpret correctly the following data.

Chemical analysis nf hand spacimens may be readtly compared with

* Since Henderson deposit çorresponds to a portion of the talc-bearing horizon, the same findings may be true for the remainder of the talc 

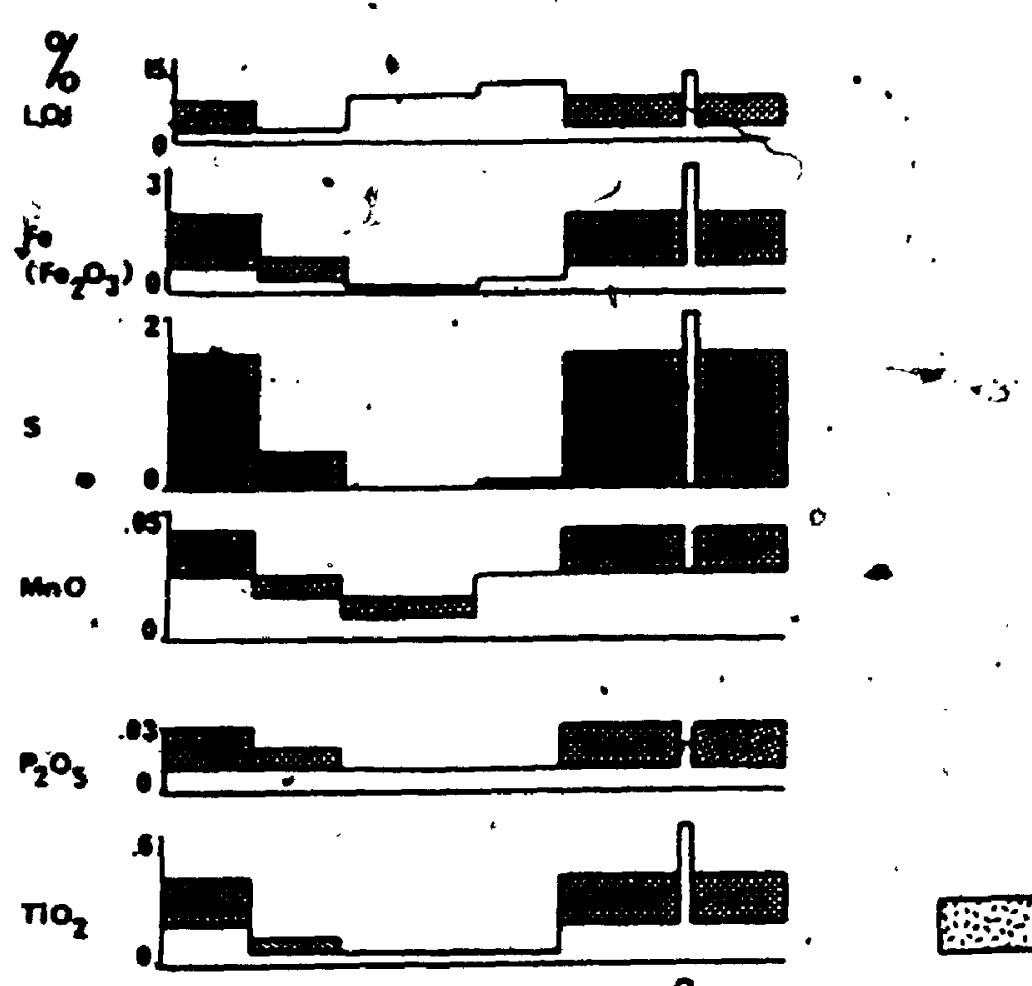

tremolitic micaceous do lowitic marble
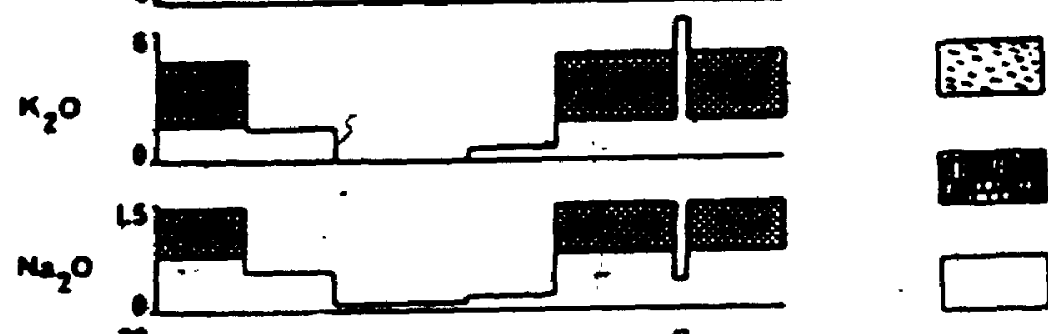

steatite

coarse flaky talc bearing rock direct transition from coarse flaky talc to tremolitic micaceóus dolomitic marble
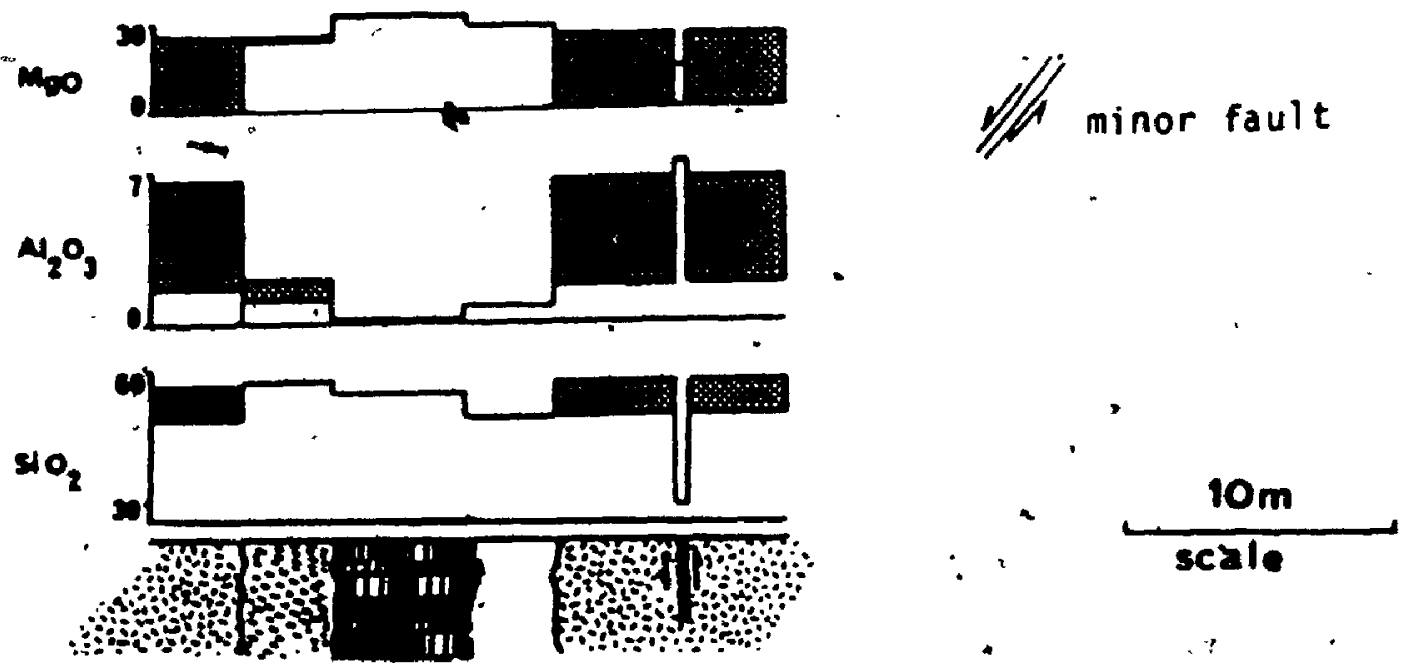

Fig. 19 - Variation in mjor elements across the Henderson deposit: (Stippled zones show a scatter in the analytical results for a given rock type.) 


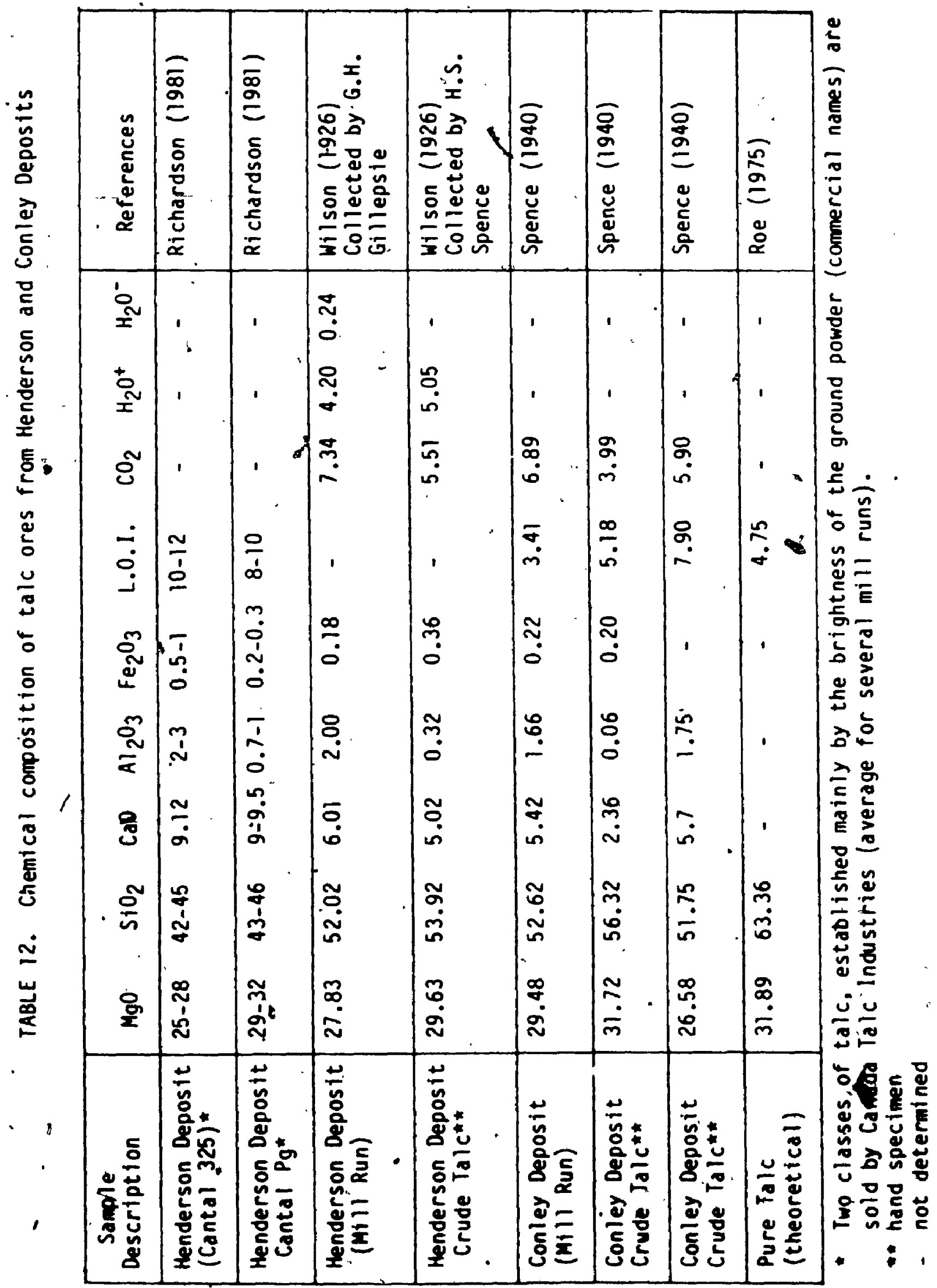




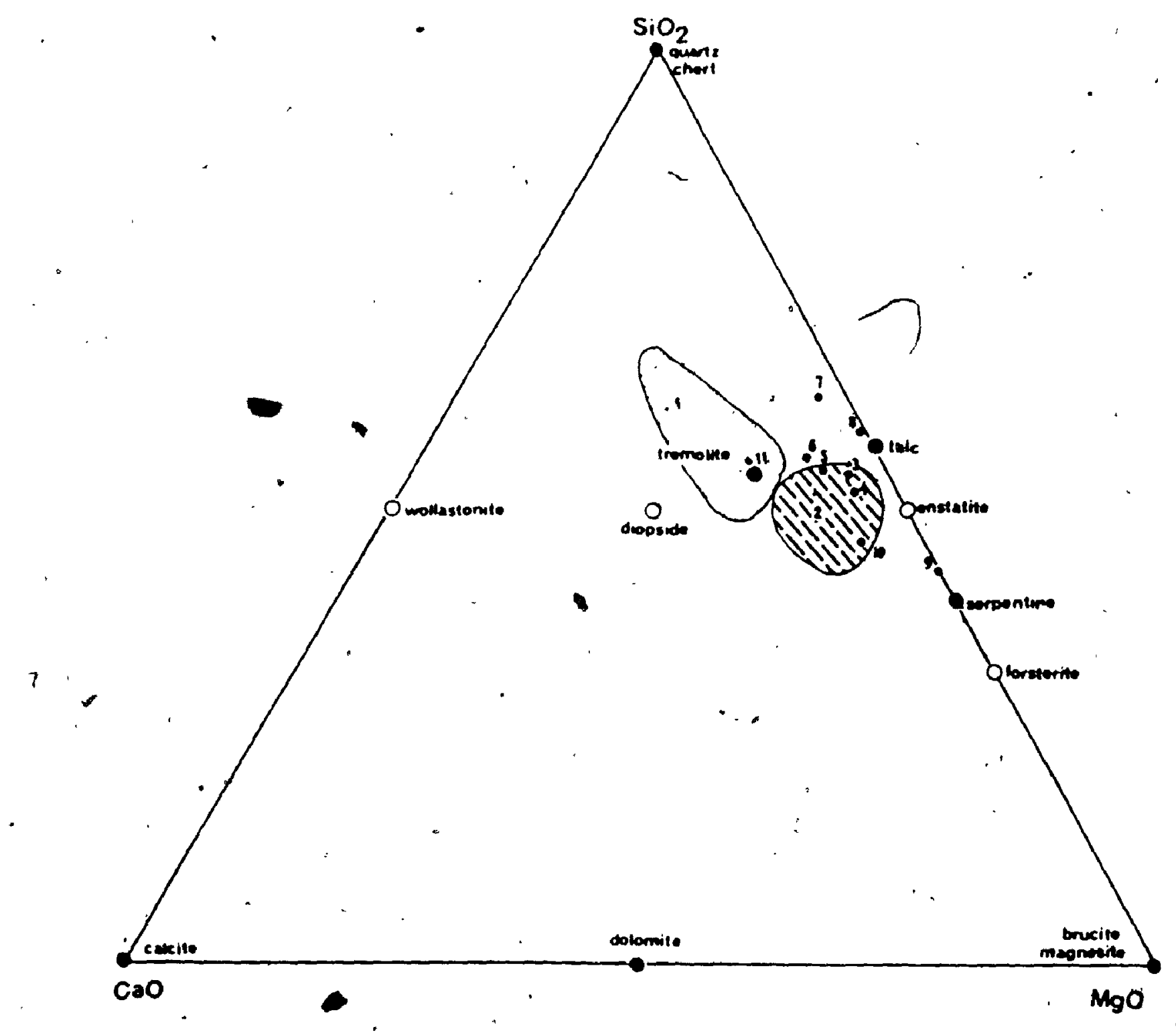

Fig. 20 - Henderson deposit compared to other occurrences of talc in 1. (shaded area) typical micaceous tremolitic marble from Henderson deposit; 2 - (hatched area) composition of talc. produced by Canada Talc Industries (Henderson and Conley deposits); 3 and 4 - coarse, flaky talc (hand spectimens) Henderson, depostt; 5 - Texas talc; 6 - average, talc ore, Talcvilule, Gouverneur District, New York; 7 - average talc ore, Fowier, Gouverneur District, Mew York; 8 - talc from Yellowstone Mino (Montana): 9 - talc from Vermont; 10 - white-talc, Murray Wonty, Georgla: 11 - highly tremolitic. talc from Stlver Lake Mine; San Bernardino County, California. Complled from Roe (1975) and Engel and Uright (1971). except for data from Henderson deposit. 
corresponding rock types; however, this type of sample does not give accurate information about bulk composition of a sampled deposit.

Mill run analysis represents better average composition of the deposit. Mill run samples from the Henderson type deposits are a mixture of coarse, flaky.talc ore, steatite and some tremolitic micaceou's marble.

The variation in the cheqistry of the talc ore (Table 12) may be explained by:

a) variation in a degree of ore dilution (increase in degree of dilution with increasing depth of slopes, with increasing age of the mine, hand pidking of the ore in early years of the production, other modifications in the mining and milling practicies);

b) increase in the CaO content of the talc-bearing rocks may be - related to the depth. Part of the calcite could have been. disssolved in near surface environment by supergene circulation of fluids. A sulfide smell (usually associated with the" oxidation of sulphides) is intense on the seventh level, near the water discharges. This suggests unusually high acidity of the water in the carbonate environments;

c) difference in the composition of protore;

d) variation in unknown parameters of the talc forming process.

6.7 Henderson deposit compared with other taic-occurrences in carbonate rocks in North America

Chemical compositions of the talc ore and host rack (tremolftic micaceous marble) of the Henderson deposit are compared with chemical 
1

composftion of talc bearing ("talc ore") rocks from other well-known North American carbonate-hosted talc deposits (Fig. 20). Chemical composition of the tremolitic micaceous marble is shown by shaded,area $(1) \star$

Chemical composition of the commercial talc produced from Henderson and Conley deposits. is represented by the hatched area (2). The chemical analyses of coarse, flaky talc $(3,4)$ compare favourably with talc produced in Texas (5) and New York (6 and 7). states.

- Talc ore from Texas and new York have nevertheless higher $\mathrm{SiO}_{2}$

- content than samples of best coarse, flaky talc ore from Henderson deposit. Steatite from the Yellowstone Mine, Montana (8) is exceptional since it corresponds closely to the theoretical talc. Vermont talc product (9) has significantly lower $\mathrm{SiO}_{2}$ content than products from all previously described locations and does not contain. any $\mathrm{CaO}_{., \mathrm{F}}$ Highly themolitic talc ore from Silver Lake Mine; San Bernardino County, California, plots very near to composition of the " theoretical tremoltte. Minor reduction of the LaO component in tremolitic micaceous dolomitic marble may produce material chemically equivalent to the talc bearing materials produced from principal carbonate hosted talc deposits of North Amerfca (with the exception of the talc from Vermont).

This brief comparison should be considered only as tentative, since it is based mostly on the talc material produced. It does not constder the variations in the mining and milling methods or variations in processing:

- Numbers in parentheses correspond to the legend of Fig. 20 . 
Analysis of the several hand specimens from each deposit would probably frovide a better basis for geochemical comparison of ores from above mentioned deposits.

\subsection{Summary}

Although not enough data was gathered to fully understand the geochemistry of Henderson and'Conley deposits, present data suggest that:

a) there exists-a negative correlation between $\mathrm{MgO}$ and $\mathrm{CaO}$ content;

b) MgO content of coarse, flaky ore is higher than that of a typical dolomite;

c) there exists little variation in composition between the individual samples of the coarse, flaky talc ore;

d) there exists geochemical zoning around Henderson deposit (either related to the process of talc formation or to geochemistry of pre-metamorphic materials). This variation is summarized in figure 19;

e) the ore from other well-known carbonate hosted talc deposits' could have been formed from the materials chemically similar to coarse micaceous dolomitic marbles of the Henderson area. 
81

CHAPTER 7: FORMATION OF TALC AND TALC DEPOSITS

7.1. Background

Talc deposits are associated with ultramafic, magic and carbonate rocks. This study is concerned with talc deposits associated with carbonate host rocks of sedimentary origin.

A literature survey indicates that talc deposits of this type may be formed by five major processes:

a) precipitation of talc on the seafloor

- near a hot submarine discharge related to volcanic activity

- in do evaporitic depositional environment

b) hydrothermal vein formation or alteration of carbonate host rock by hydrothermal activity

c) prograde metamorphism of siliceous dolostone

d) prograde metamorphism of siliceous sedimentary magnesite

e) retrograde metamorphism.

7.1.1 Formation of talc on the seafloor

Talc has been observed on the seafloor near hot submarine discharges and in marine evaporite environments (Costa et a 1. 1980).

Talc occurrences associated with- $2 n-C u$ sulphide deposits in the Matagami mining -district of Quebec have formed from the reaction of discharge of silica-rich fluids with the metal bicarbonate species of ocean water according to' reaction (Costa et a 1. 1980):

$$
3 \overline{\mathrm{Mg}}^{2}+6 \mathrm{HCO}_{3}+4 \mathrm{SiO}_{2} \longrightarrow \mathrm{Mg}_{3} \mathrm{Si}_{4} \mathrm{O}_{1 \mathrm{O}} \mathrm{O}(\mathrm{OH})_{2}+6 \mathrm{COO}_{2}+2 \mathrm{H}_{2} \mathrm{O}
$$


Talc or serpentine cannot be formed at room temperature, but can be "readily formed at temperatures of $90^{\circ} \mathrm{C}$ and above, from precursors such as sepiolite (Bricker 1973).

The following reaction may be cesponsible for sepiolite precipitation in the above described en ronment (Costa et al. 1980):

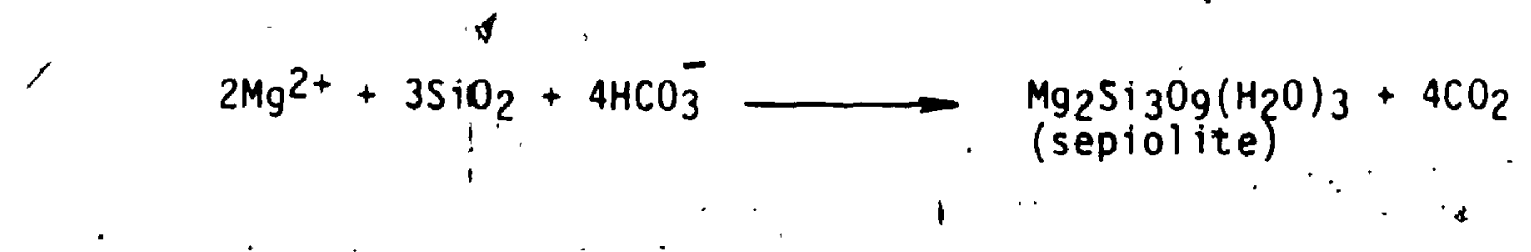

Sepiolite may be readily transformed to talc (Costa et al. 1980).. Talc with sulphides has been recorded in Guaymas Basin (Lonsdale 1978). in the Sea of Japan (Shirozu 1974) and in solution vents associated with metalliferous sediments in Atlantis 11 Deep, Red Sea (Zierenberg and Shanks 1983, Costa et al. 1983).

Authigenic talc and seprolite have been observed within evaporite deposits (Alderman and Van der Borch 1960, 1961, Fuchstbauer and Bodine 1972, Steward 1963, Wollast et al. 1968, Van der Borch 1976).

The stabjlity fields of sepiolite, serpentine, talc and amorphous silica, compared with seawater and interstitial waters in modern surface sediments (Fig. 21) indicate that all the Mg-silicates noted above could be stable in modern marine sediments and that $\mathrm{pH}$ is an important control for stability of talc, sepiolite and serpentine (Costa et al. 1980).

7.1.2 Hydrothermal ("vein forming") activity

A hydrothermal origin has been advanced to explain.the genesis of talc deposits in a wide variety of geological enrtronments (including $+$ 


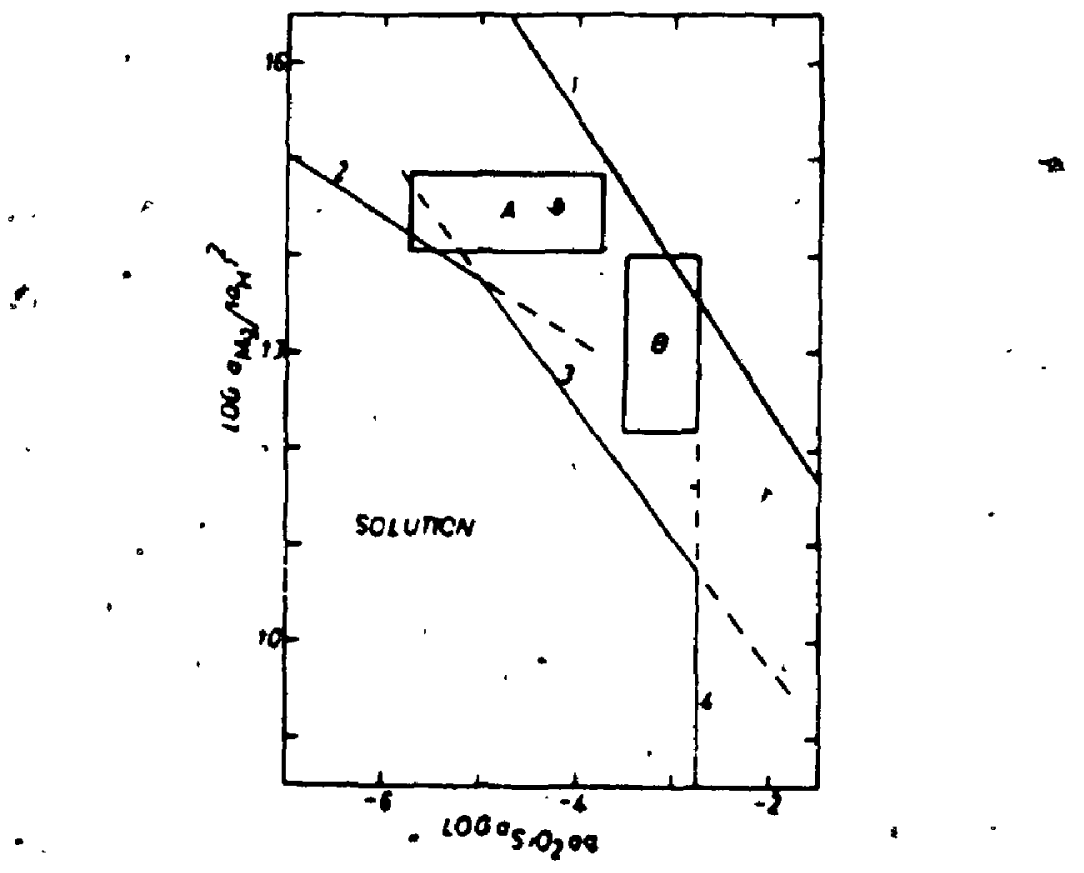

Fig. 21 - Solubility relations of magnesian silicates in aqueous solutions $\left(25^{\circ} \mathrm{C}, 1\right.$ bar total pressure). Solutions plotting above curve 1 will precipitate sepiolite, above curve 2 a serpentine mineral (chrysotile). Curves' 3 and 4 illustrate talc and amorphous sillica saturation. Haters plotting in the solution field should dissolve all of the above minerals. Area $A$ represents the range of conditions in surface seawater and area $B$ the range in seawater trapped in modern marine sediments (Costa et ar. 1980). 
carbonate rocks.). The best known examples are structurally controlled talc deposits of the French Pyrenean massif described by Aranitis (1967), Capdecome (1950), Iwart (1953), Guitard (1973), Fortune et al. (1980). Two major hypotheses emerged from these studies (fortune et al. 1980):

a) formation of talc by the netasomatism of dolomites. with siliceous solutions (Capdecome 1950 and 2 watt 1953) accordting to reaction:

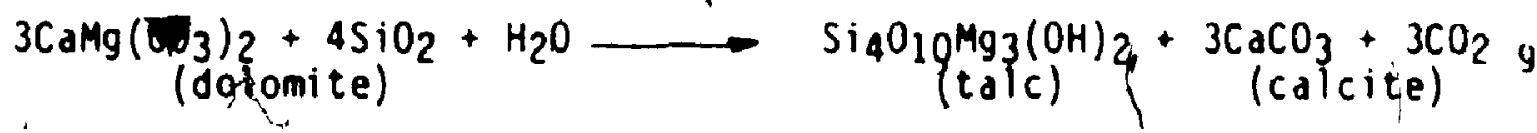

b) formation of talc by magnesia bearing solutions (Aranitis 1967). which percolate through fractires in the host rock altering muscovite to clinochlore and liberating sillica, dissolving quarti and dolomitizing calcium carbonates.

Magnesium bearing solutions acquiring silica the above manner may precipitate talc according to reaction below:

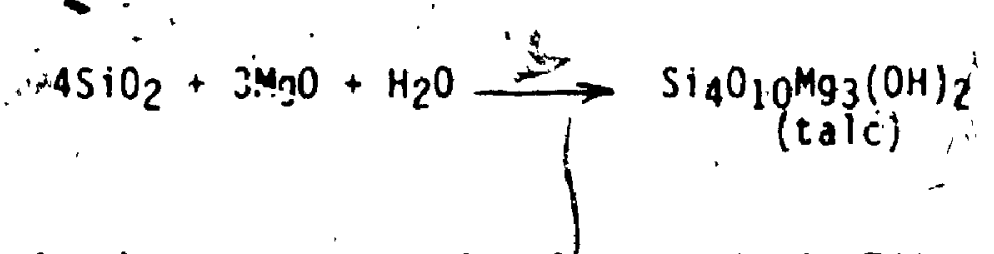

An example of a hydrothermal tape deposit is Trimouns deposit near

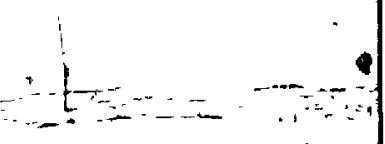

\section{Luzenac (France), one of the largest known talc teposits. Six mjllion} tons have already been extracted and reserves are aboutt 18 .mi ija tons - (Frtune et ai. 1980). The footwall of the deposit is compgsed of some Barthelemie crystalline formation) (gneiss, migmatcites and mica, schists). The hanging-wall consisto of "chlorito graphitic" schists with intertalations of dolomite (Fortune et al. 1980). 

The deposit is composed essentially of talc and chlorite. The main deposit is a lens which dips $40^{\circ}$ to $80^{\circ}$ (Fig. 23). The lens is irregular, its thickness varies from 9 to 80 metres and it can be traced for $5 \mathrm{~km}$ (Fortune et al. 1980). It corresponds to a shear zone which was permeable to percolating solutions (Fortune et al. 1980).

The Trimouns depostt was formed by at least two talc forming processes (Fortune et al. 1980):

f) magnesium rich solutions reacted with aluminosilicates to form "chloritoschists" and with siliceous rocks to form talc;

ii) silica (liberated by alteration of aluminosiltcates to chlorite and by dissolution of quartz and unstable silicates) travelled in solution and altered dolomite into talc.

The source of the magnesium is not clear. Fortune et al. (1980), suggest as the most próbable sources of magnesium: a) solution of deep seated dolomite; (b) dedolomitization related to formation of calcitic marbles during a period of migmatization and migration of solution to higher levels.

The temperature of the talc formation was estimated at $300^{\circ} \mathrm{C}$, based on the tremolite to talc transformation (Fortune et al. 1980).

\subsection{Progressive metamorphism of siliceous dolostones}

Metamorphism of siliceous dolostones and limestones received much attention following Bowen's (1.940) publication dealing with the subject. Bowen's (1940) systematic study of the siliceous dolomitic Iimestone outlined thirteen steps of increasing decarbonation with increasing temperature at constant pressure. Talc was added to Bowen's (1940) metamorphic suite by Tilley (1948). 
The stability of talc has been determined by experimental methods,

- thermodynamic calculations and by detailed petrographic studies.

The stability of talc is dependent on the physical conditions (temperature, pressure), chemical composition of host rock, and chemical composition of the fluids. Metamorphism of a siliceous dolomitic 1 imestone may be approximated by the $\mathrm{MgO}-\mathrm{SiO}_{2}-\mathrm{CaO}-\mathrm{H}_{2} \mathrm{O}-\mathrm{CO}_{2}$ system. An excellent synthesis of the information concerning this system was produced by winkler (1979) and much of the following discussion is derived from his work. Assuming that the fluid pressure is $5 \mathrm{KD}^{\star}$, original material is siliceous dolomite, the influence of impurities is negligible, and that minerals involved have ideal composition, then $\mathrm{X}-\mathrm{CO}_{2}$ and temperature are the factors controlling the stability of talc. Talc is stable at temperatures up to $550^{\circ} \mathrm{C}$ under the above conditions. The temperature required for talc formation is lowered if the mole fraction of $\mathrm{CO}_{2}$ decreases (Fig. 23).

Three reactions may be responsibie for the formation of talc in this system (reactions 1, 2, 3 in Fig. 23).

Other minerals may be formed by the progressive metamorphism of siliceous dolomite (equations 5,9, 10, 12, 14 and 15, Table 13).

Reactions 5 and 15 may take place only if the original dolomite rock (prior to metamorphism) contained magnesite and quartz (Winkler 1979).

Reactions 9, 10 and 12 are metastable (Metz, 1976). If the pressure is other than $5 \mathrm{~Kb}$ the location of reactions on the T-X $x_{c 02}$ diagrams. change but the diagram nevertheless retains the same general appearance.

- $3.5 \mathrm{~Kb}$ or $4 \mathrm{~Kb}$ fluid pressure is probably more realistic in the mine If metamorphic conditions are consistent with "Idahoan" field gradtent as established by Sethuraman and Moore (1973). 

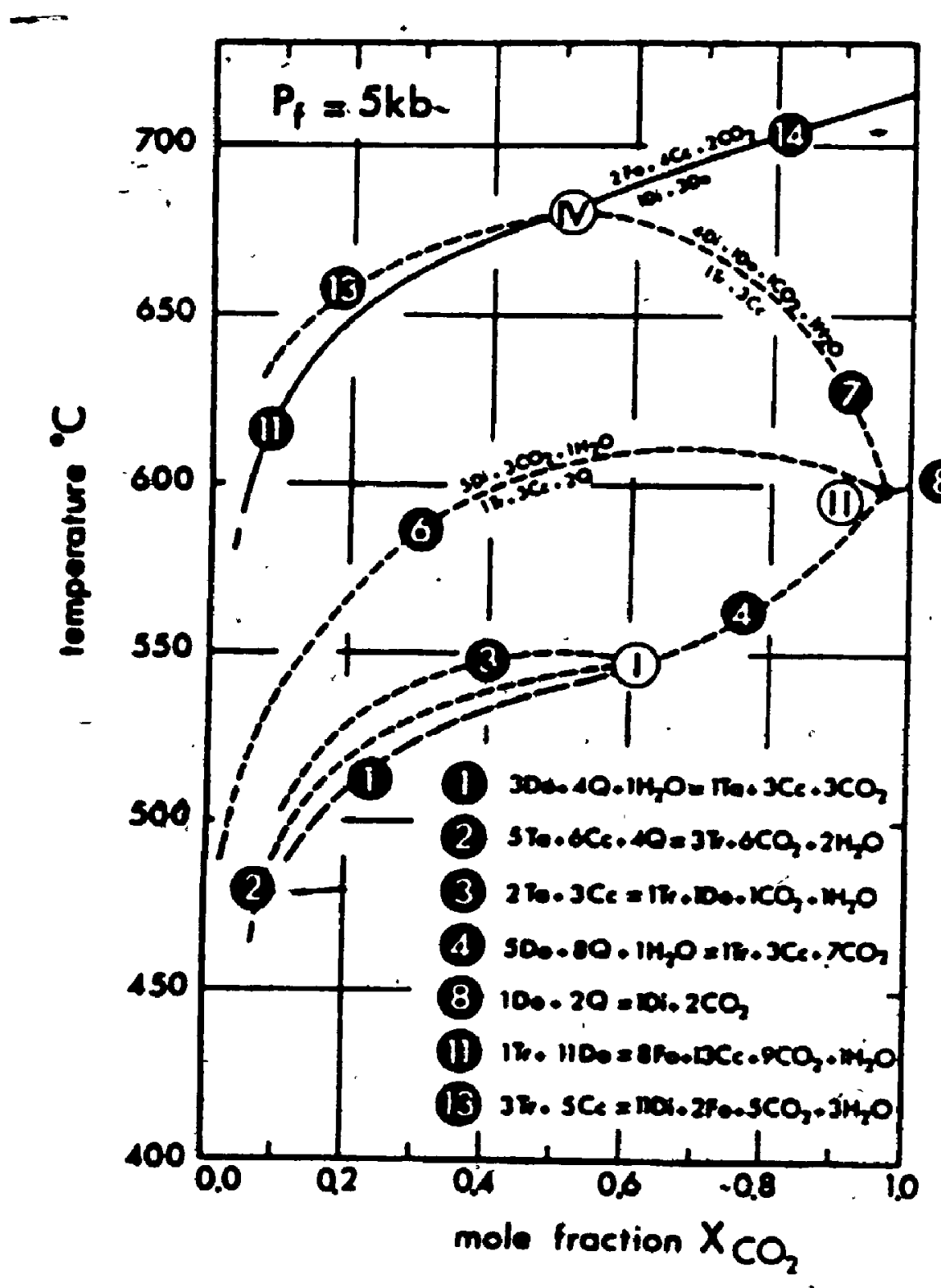

8

Fig. 23 - Isobaric $T-X_{c o 2}$ diagram at $5 \mathrm{~Kb}$ fluid pressure for reactions in sfliceous dolostone (Winkler 1979). 
TABLE 13. Metamor.phic reactions in siliceous dolostone. Reactions 9, 10 and 12 are metastable (Winkler 1979).

3 dolomite +4 quartz $+1 \mathrm{H}_{2} \mathrm{O}=1$ talc

+3 calcite + $3 \mathrm{CO}$,

3 talc +6 calcite +4 quanz $=3$ tremolice

$$
+6 \mathrm{CO}_{2}+2 \mathrm{H}_{2} \mathrm{O}
$$

2 talc +3 calcite $=1$ tremolite +1 dolomite

$$
+1 \mathrm{CO}_{2}+1 \mathrm{H}_{2} \mathrm{O}
$$

5 dolomite +8 quarz $+1 \mathrm{H}_{2} \mathrm{O}=1$ iremolite

$$
+3 \text { calcile }+7 \mathrm{CO}_{2}
$$

2 dolomite +1 ialc +4 quarz $=1$ tremolite $+4 \mathrm{CO}_{1}$

1 semolite + 3 calcite + 2 quartz $=3$ diopside

1 iremolite +3 calcite $=1+3 \mathrm{CO}_{2}+1 \mathrm{H}_{2} \mathrm{O}$

1 dolomite +2 quartz $=1$ diopside $+2 \mathrm{CO}_{2}$

olomite +4 diopside

1 talc +5 dolomite $=4$ forsterite +5 catcite $+\mathrm{SCO}_{2}+1 \mathrm{H}_{2} \mathrm{O}$

11 talc +10 calcite $=3$ tremolite +4 forsterite

$$
+10 \mathrm{CO}_{2}+6 \mathrm{H}_{2} \mathrm{O}
$$

I tremolite +11 dolomite $=8$ forsterite +13 calcite

$$
+9 \mathrm{CO}_{2}+1 \mathrm{H}_{3} \mathrm{O}
$$

13 talc +10 dolomite $=3$ tremolite +12 forsterite

3 tremolite $+\$$ calcite $=11$ diopside +2 forsterite

$$
+\mathrm{SCO}_{2}+3 \mathrm{H}_{2} \mathrm{O}
$$

1 diopside +3 dolomite $=2$ forsterite +4 calcite $+2 \mathrm{CO}_{2}$

4 tremolite +5 dolomite $=13$ diopside +6 forsterite

$$
+10 \mathrm{CO}_{2}+4 \mathrm{H}_{2} \mathrm{O}
$$


Literature survey Indicates that there are no economic tajc deposits known to have formed by metamorphism of silliceous dolostone.

\section{.. \\ 7.3 Metamorphism of siliceous magnesite}

The MgO-SiO $\mathrm{O}_{2}-\mathrm{CO}_{2}-\mathrm{H}_{2} \mathrm{O}$ system is used to p oject compositions of metamorphtc mineral assemblages of $y 1$ tramaficfrocks; the same system can also be applied to siliceous magnesite befling rocks of sedimentary origin (Winkler 1979). Rocks of this type are known to form at present in Coorong Lagoon of southeast South Australla (Alderman 1965). Extensive silfceous magnesite deposits are known in Southern Pithoragarh, India (Valdia 1968). These deposits are usually planar, stratigraphically controlled, invariably associated with algal bioherms and are relatted to $\mathrm{high} \mathrm{Mg} / \mathrm{Ca}$ ratio in basin waters (Valdia 1968). The $\mathrm{Mg} / \mathrm{Ca}$ ratio increased with time as a result of biogenic extraction and/or inorganic precipitation of $\mathrm{CaCO}_{3}$ within the basin. Early formed carbonates are converted into high magnesium carbonates under high $\mathrm{Mg} / \mathrm{Ca}$ ratio (attributed to algae growth) and high pH conditions (Valdia 1968). Interstitial talc formed from the reaction of quartz with magnesite during the metamorphism (Valdia 1968).

Important reactions to be considered in the general study of the metamorphtsm in $\mathrm{MgO}-\mathrm{SiO}_{2}-\mathrm{H}_{2} \mathrm{O}-\mathrm{CO}_{2}$ system (described by Winkler 1979) are given in Table 14, and the corresponding equilibrium curves at fiuid pressure of $2 \mathrm{~Kb}$ are given in Figure 24. Isobaric equilibrium curves at fluid pressures of $4 \mathrm{~Kb}, 2 \mathrm{~Kb}$ and $1 \mathrm{~Kb}$ respectively are given in Figure 26.

Isobartc equilibrium curves of reactions occurring as large mole $\therefore$ fractions of $x_{\text {cO2 }}$ are presented in figure 27 . Reactions $2,3,4,7,8$, 


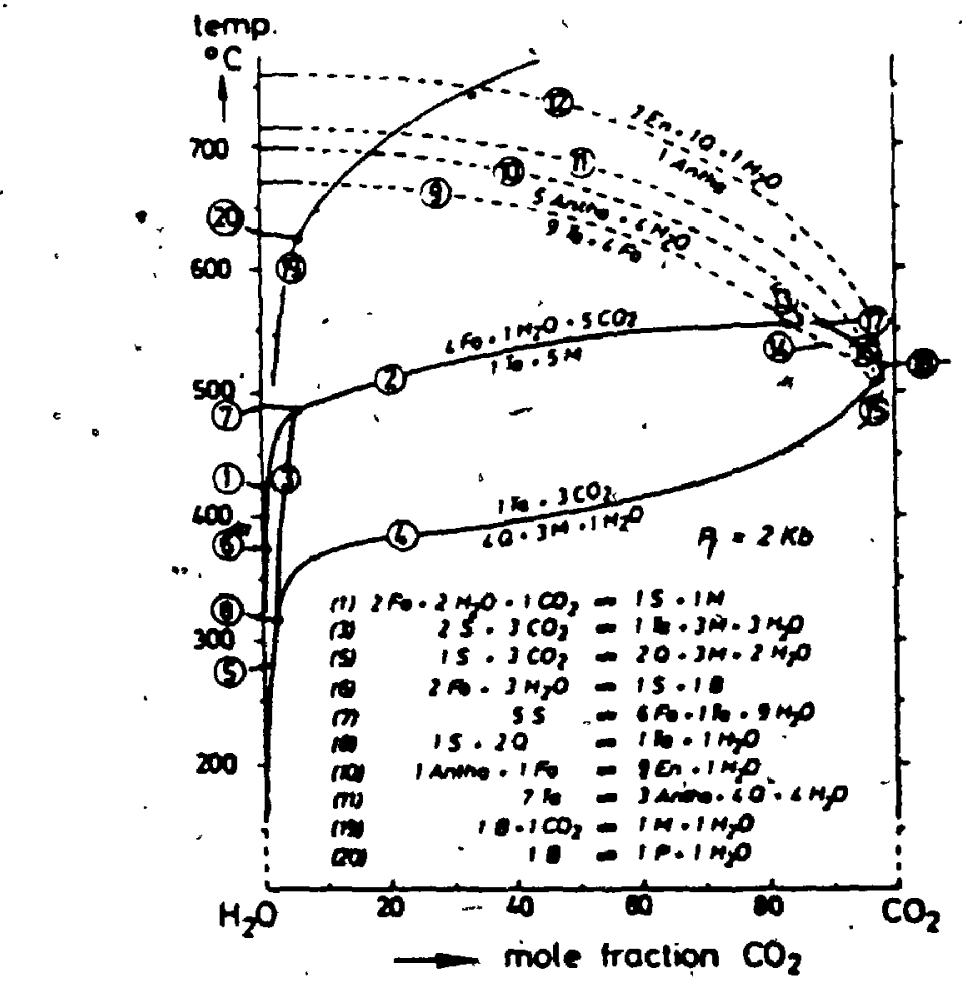

Fig. 24 - Isobaric equilibrium curves (at $2 \mathrm{~kb}$ ) of reactions (1) through (20) in the system $\mathrm{MgO}-\mathrm{SiO}_{2}-\mathrm{H}_{2} \mathrm{O}-\mathrm{CO}_{2}$.

Remark: The experimental data for reactions (6) and (7) have been obtained using chrysotile as the serpentine species. Using antigorite instead of chrysotile gitues rise to somewhat higher equilibirium temperatures (Winkler 1979). 

TABLE 14. Key reactions in $\mathrm{MgO}-\mathrm{SiO}_{2}-\mathrm{H}_{2} \mathrm{O}-\mathrm{CO}_{2}$ system (Winkler 1979).

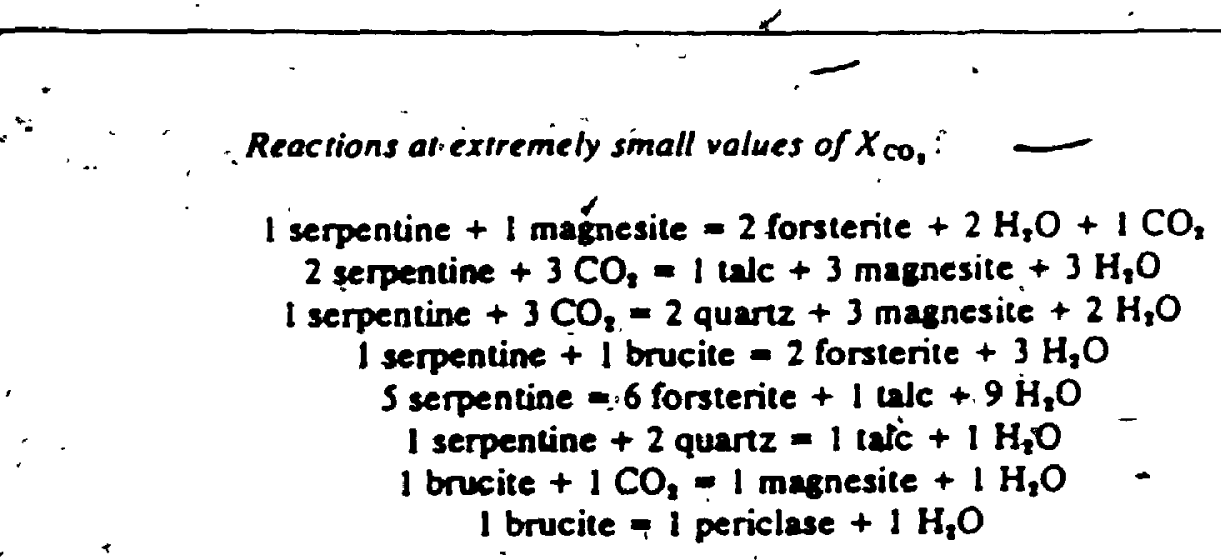

Reactions within a large intermediate range of $X_{\mathrm{co}}$, between the extremes:

$$
\begin{aligned}
& 1 \text { talc }+5 \text { mbenesite }=4 \text { forsterite }+1 \mathrm{H}_{2} \mathrm{O}+5 \mathrm{CO}_{2} \\
& 4 \text { quartz }+3 \text { magnesite }+1 \mathrm{H}_{2} \mathrm{O}=1 \mathrm{talc}+3 \mathrm{CO}_{2} \\
& 9 \text { tale }+4 \text { forsterite }=5 \text { anthophyllite }+4 \mathrm{HO} \\
& 1 \text { anthophyllite }+1 \text { forsterite }=9 \text { enstatite }+1 \mathrm{H}_{2} \mathrm{O} \\
& 7 \text { talc }=3 \text { anthophyllite }+4 \text { quartz }+4 \mathrm{H}_{2} \mathrm{O} \\
& 1 \text { anthophyllite }=7 \text { enstatite }+1 \text { quartz }+1 \mathrm{H}_{2} \mathrm{O}
\end{aligned}
$$

- Reactions at extremely large values of $X_{\mathrm{CO}_{1}}$ :

1 anthophyllite + 9 magnesite -8 forsterite $+1 \mathrm{H}_{2} \mathrm{O}+9 \mathrm{CO}_{2}$ 2 talc +1 magnesite $=1$ inthophyllite $+1 \mathrm{H}_{2} \mathrm{O}+1 \mathrm{CO}_{2}$ Inagesite +8 quartz $+1 \mathrm{H}_{2} \mathrm{O}=1$ anthophyllite $+7 \mathrm{CO}$, 1 anthophyllite +1 magnesite $=4$ enstatice $+1 \mathrm{H}_{2} \mathrm{O}+1 \mathrm{CO}_{2}$ 1 enstatire +2 magnesite $=2$ forsterite $+2 \mathrm{CO}_{3}$

2 magnesite +2 quartz $=1$ enstatite $+2 \mathrm{CO}_{2}$ 


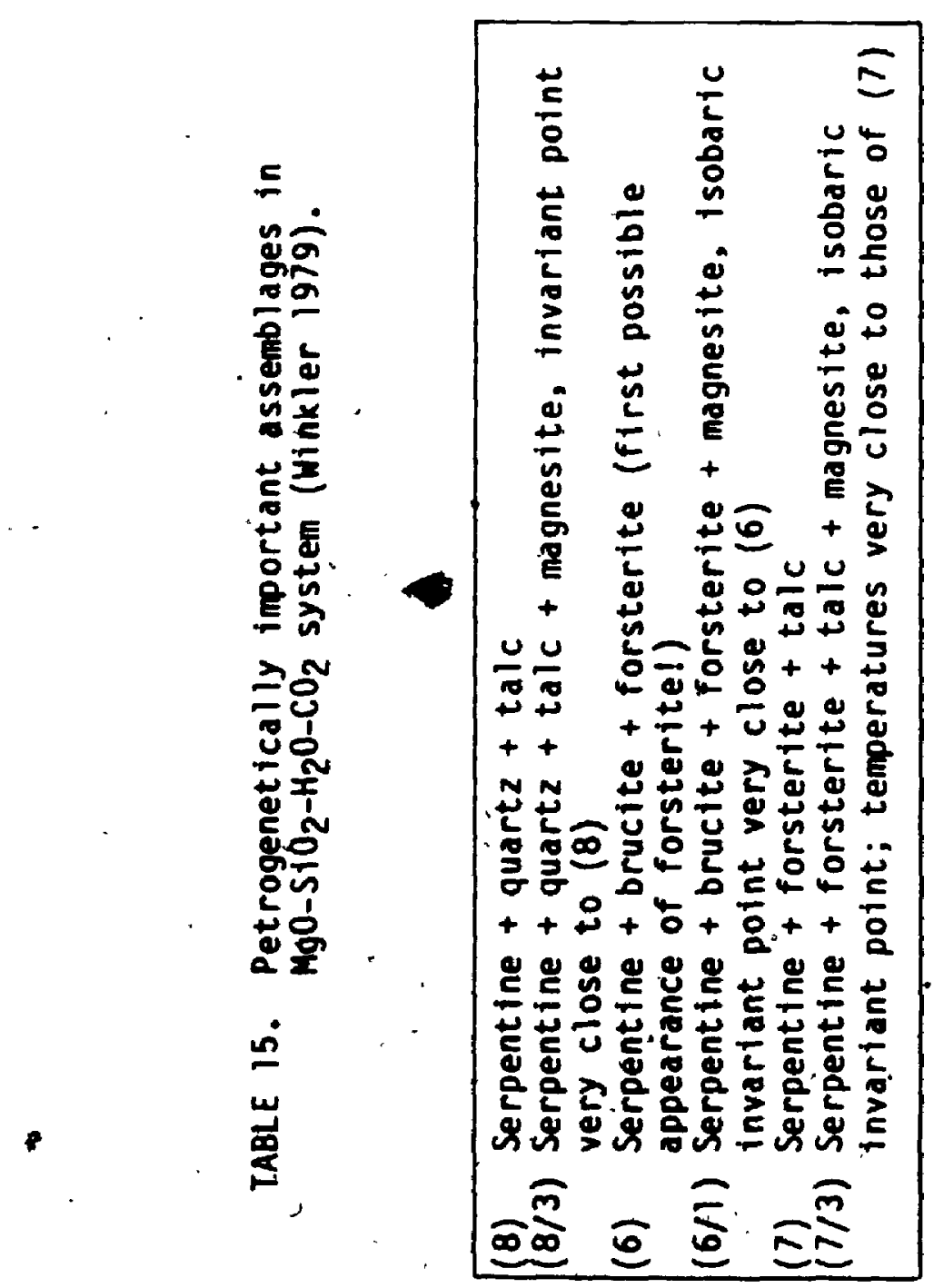




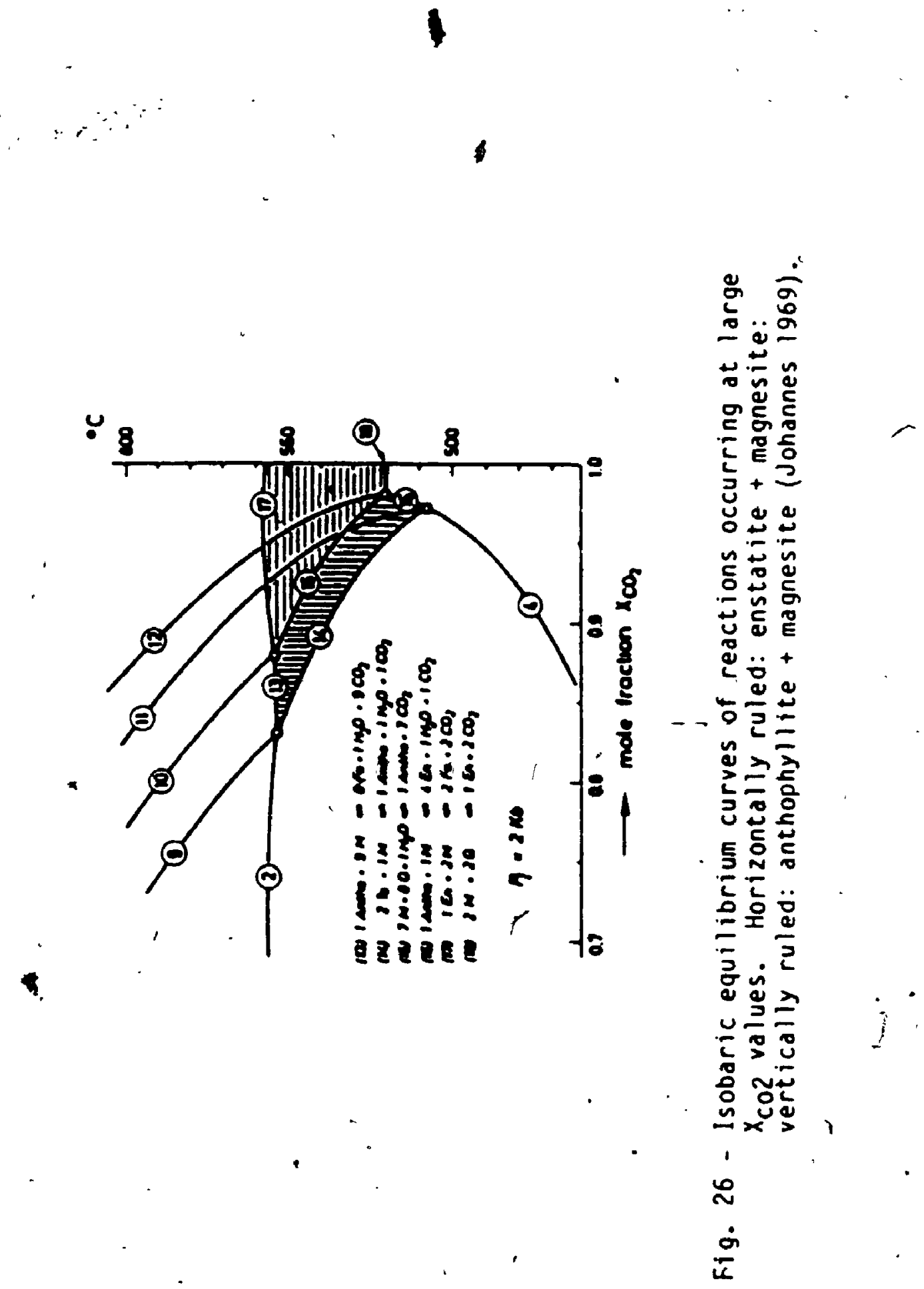


- 9. 11 and 14 (Table 14) may be involved in formation of talc under

favourable prevalling condtions. Petrogenetically important assemblages ace listed in Table 15.

The influence of $\mathrm{Al}_{2} \mathrm{O}_{3}, \mathrm{CaO}, \mathrm{FeO}, \mathrm{F}$ or other species may modify the stabilịty fields and stabilize additional minerals (Winkler 1979, p. 162-166 and Mercolli 1980).

\subsection{Retrograde metamorphism}

All the reactions consfdered in the section on metamorphism of sfliceous dolostone and magnesite can proceed in both directions. Retrograde metamorphism, the process whereby higher grade metamorphic rocks are transformed into lower grade ones, is known to occur mainly along shear zones and fracture zones where $\mathrm{H}_{2} \mathrm{O}$ and $\mathrm{CO}_{2}$ may circulate (Winkler 1979); Retrograde metamorphism is treated here as an tndividual talc forming process mainly because it is treated as such by most praticing exploration geologists (for example, Bates 1969).

The combination of metamorphic and hydrothermal "vein forming" activity is proposed for talc formation in the Gouverneur district by Bates (1969). Bates describes (p. 332) the process as:

"The tremolite was probabTy formed during severe stages of regional metamorphism (Engel 1947). Its calcium, magnesium, and silica were made avallable by reactions between, and replacement of, favourable beas of quartzite and metadolomite. The mobile agents were hydrothermal solutions at high temperatiures, probably charged with silica. Increasing intensity of metamorphism produced diopside and other anhydrous stificates. Serpentine and talc did not make their appearance unt $f 1$ later stages of retrograde metamorphism and falling temperature at which time abundant magnestum was avallable in solution. Serpentine and talc, in other words, formed at the expense of earlier silicates largely as fibrous pseudomorphs after tremolite." 


\subsection{Discusstons}

A Ifterature survey indicates that the genesis of talc deposits is believed to be mainly of a hydrothermal vein forming. No reforence to economically significant talc deposits exists in which metamorphism of siliceous dolomite or magnesite is recogntzed as the main talc forming process. The same applies for the process where talc is formed by reaction of silica with metal bicarbonate near a hot submarine discharge or by precipitation in evaporitic environment. Retrograde metamorphism is mostly suggested on the basis of retrograde textures observed in than sections. No significant information exchange exists between contemporary researchers in petrology and practicing economic geologists of the industrial mineral sector. The dominance of the hydrothermal vein forming process may be therefore only apparent. 
CHAPTEK 8: ORIGIN OF THE HEMOERS.JM TALC OEPOSIT

$\therefore$ The Henderson deposit is trajitionalily regarded as hydrothermal, (İable 16). Hewitt (1968) writes:

"The best explanation as to the origin of thesc talc deposits is that of Wilson (1926) who regarded them as hydrothermal replacement

$\therefore$ deposits. Conformable sheet-like bodies of talc were developed - Prom the Grenville dolomite by the introduction of hydrothermal solutions that probably originated from the neighbouring Moira granite. These hot-water silica-bearing solutions ascended fractures and faults on the south limb of the anticline and altered the dolomite first to tremolite and then to talc. Evidence of this doloaite-tremolite-talc transition can be seen in thin sections of the rocks from the deposit. Subsequent folding and faulting is responsible for the crenulatin, thickening, and off setting of the talc ore sheets. The madocite dikes and the hydrothermil solutions probably had a comanon origin in the Moira granite magma. The talc does not appear to be particularly assoctated genetically or spatially with the dikes thenselves."

\subsection{Critical observations}

Any genetic model which atterpts to explain the origin of the. lienderson. Conley and East deposits inst satisfy the following stratigraphic, structural, morphological, petrological, mineralogical and geochemical restrictions.

Stratigraphic criteria:

1. Menderson, Conley and East deposits are related to the same stratigraphic horizon, near the metapelite-marble transition.

2. Talc deposits occur in atcaceous tremolitic marbles.

3. Talc deposits occur near quartzite with stromatotitic textures.

4. At least one $\mathrm{Zn}, \mathrm{Cu}$, deposit is located on the same stratigraphic norizon in the doc area (simand, in preparation).

5. Footwall, hanging wall, and steatite ca in fine and regular sedimentary laminations. 
TABLE 16. Origin of the Henderson Talc Deposit (compllation from the literature)

\begin{tabular}{|c|c|c|}
\hline AUTHOR & YEAR & POSTULATED ORIGIN \\
\hline Wilson & 1926 & $\begin{array}{l}\text { Silication of the dolomite through the } \\
\text { action of solutions emanating from the } \\
\text { Moira granite. (Openings now occupied by. } \\
\text { dykes were probably the channels dlong } \\
\text { which these emanations ascended). }\end{array}$ \\
\hline Spence & 1940 & Same as Wilson, 1926. \\
\hline Sandomirsky & 1954 & $\begin{array}{l}\text { Enumerates all the soures of } \mathrm{MgO} \text { and } \mathrm{SiO}_{2} \\
\text { considers several origins but in the end } \\
\text { also favours Wilson's } 1926 \text {. theory. }\end{array}$ \\
\hline Hewitt & $\begin{array}{l}1957 \\
\text { p.21 }\end{array}$ & $\begin{array}{l}\text { Essentially same as Wilson } 1926 \text {, but the } \\
\text { silfca-bearing aqueous solutions ascended } \\
\text { through fracturas and faults. Hewitt diso } \\
\text { writes: "Madocite dykes do not appear to be } \\
\text { particularly associated genetically and } \\
\text { spatially with the ore themselves". }\end{array}$ \\
\hline Roscoe & $\begin{array}{l}1966 \\
\text { p. } 52\end{array}$ & $\begin{array}{l}\text { Roscoe concluded: "Conditions needed to } \\
\text { form talc ore are: abundant Mg0, Sia } 2 \text { and } \\
\text { fairly low temperatures and pressures, } \\
\text { Since these conditions appear to have } \\
\text { existed through the mine area to a limted } \\
\text { extent, some other control is necessary to } \\
\text { concentrate or idealize these conditions. } \\
\text { This control is structure. The structural } \\
\text { control may be faulted-fold or folded- } \\
\text { fault.". }\end{array}$ \\
\hline
\end{tabular}


6. Small scale cross bedding was found in steatite blocks.

7. Chert layers contatning dissiminated pyrite and dravite porphyroblasts are coman in the tremolitic micaceous marble.

Structural and marphological restrictions:

8. The contact between ore and host rock may be sharp or gradual over

\& up to $1.7 \mathrm{~m}$. The contacts between coarse, flaky talc ore and steatite do not follow individod sedimentary iaminations.

9. Deposits are strattabound and form sheets and lenses of variable thickness.

10. The talc-bearing horizon is folded and of fet, by faulting.

11. Anphibolité dyxes and inicaceous suiphide-bearing veins cat the laminations within tremolitic, micaceous marble and steatite (s ame dykes are folded).

12. Oykes or blocks of dyke material occur inside the talc"ore.

13. Dykes cannot be correlated between the hanging wall and footwall of the Henderson deposit, but dykes were reported to cut the ore in the Conley and East deposits.

14. Dravite porphyroblasts in the host rock are flatteged (forming "pancakes") and oriented parallel to the rock cleavage.

15. Dravite porphyroblasts in the coarse talc are and steatite are not deformed, or only slightly deformed.

Petrologic and mineralogic restrictions:

16. Coarse taic fiakes are pure white (probably low in iron) 17. Serpentine is present in'taic ore. -18. Brtcrte is present in the mine area. 
19. Tremolite, talc and quartz occur in steatite. Because these minerals were recognized in $X$-ray data, it is not clear if all three are in contact.

20. Talc is present as pseudormorphs after tremolite or actinolite (retrograde textures).

21. Two generations of tremolite-actinolite minerals (first strongly altered and second fresh) were observed in black "phyllite" beds.

22. Quartz-talc-calcite assemblage was observed in stromatolitic quartzite with stromatolitic texture.

23. The talc ore is of two textural types:

a) coarse, flaky white talc ore without sedimentary textures

b) laminated, fine-grained to aphanitic steatite.

24. Calcite is absent in coarse, flaky talc ore, minor or absent in - steatite, but abundant in surrounding micaceous tremolitic marble.

25. Remants of dolomite and tremolite crystals are visible in coarse, flaky white talc ore.

26. The major minerals of Henderson type ore are: talc (71x), dolomite (24x); minor constituents are mica, serpentine, tremolite, chlorite, vermiculite and quartz. Calcite is absent or in trace. N.B. Serpentine may be a major constituent in steatite.

27. Dravite phenocrysts contains quartz inclusions if embedded in chert, and tremolite inclusions if elibedded in the marble.

28. Tremolite is widespread in the mine area, but talc concentrations are very localized.

29. Isobaric divariant mineral assemblages (such as phlogopite-calcite, tremolite-calcite) are bundant: however, coexistence of reactants and products (such as phlogopite-calctie-dolomite-quartz, $K$ - 
feldspar, tremolite-calcite-dolomite-quartz) is uncommon. 30. Vertical, mineralogical zoning fithin the Henderson and East deposits is characterized by higher concentrations of tremolite and calcite with depth.

Geochemical restrictions: s.

31. Chemical-compositions of tremolitic micaceous marble and steatite are similar to composition of coarse, flaky talc ore.

32. Chemical zoning perpendicular to strike of the deposit is well devel oped.

33. The MgO/CaO ratios in coarse, flaky talc ore is unusually high.

34. Negative correlation exists between $\mathrm{MgO}$ and $\mathrm{CaO}$.

35. Homogenization in chemical composition is evident as one approaches the talc deposit.

8.2 Applicability of genetic models to Henderson-type talc deposits This section consists of three distinct parts. The first part relates the 35 criteria previously described to genetic models presented in Chapter 7.

The second part combines selected criteria to generate additional restrictions regarding the time of talc formation, conditions that prevalled at the time of deposition of sediments which formed the prötolith, closed vs. open system, character of talc-forming fluid(s) and upper temperature limits of tale formation.

The third part contains a newly proposed genetic model which reconcillates the $35^{\circ}$ criteria, the limits generatind by combining selected criteria, and tectonic framework proposed by Moore and Thompson (1980). 


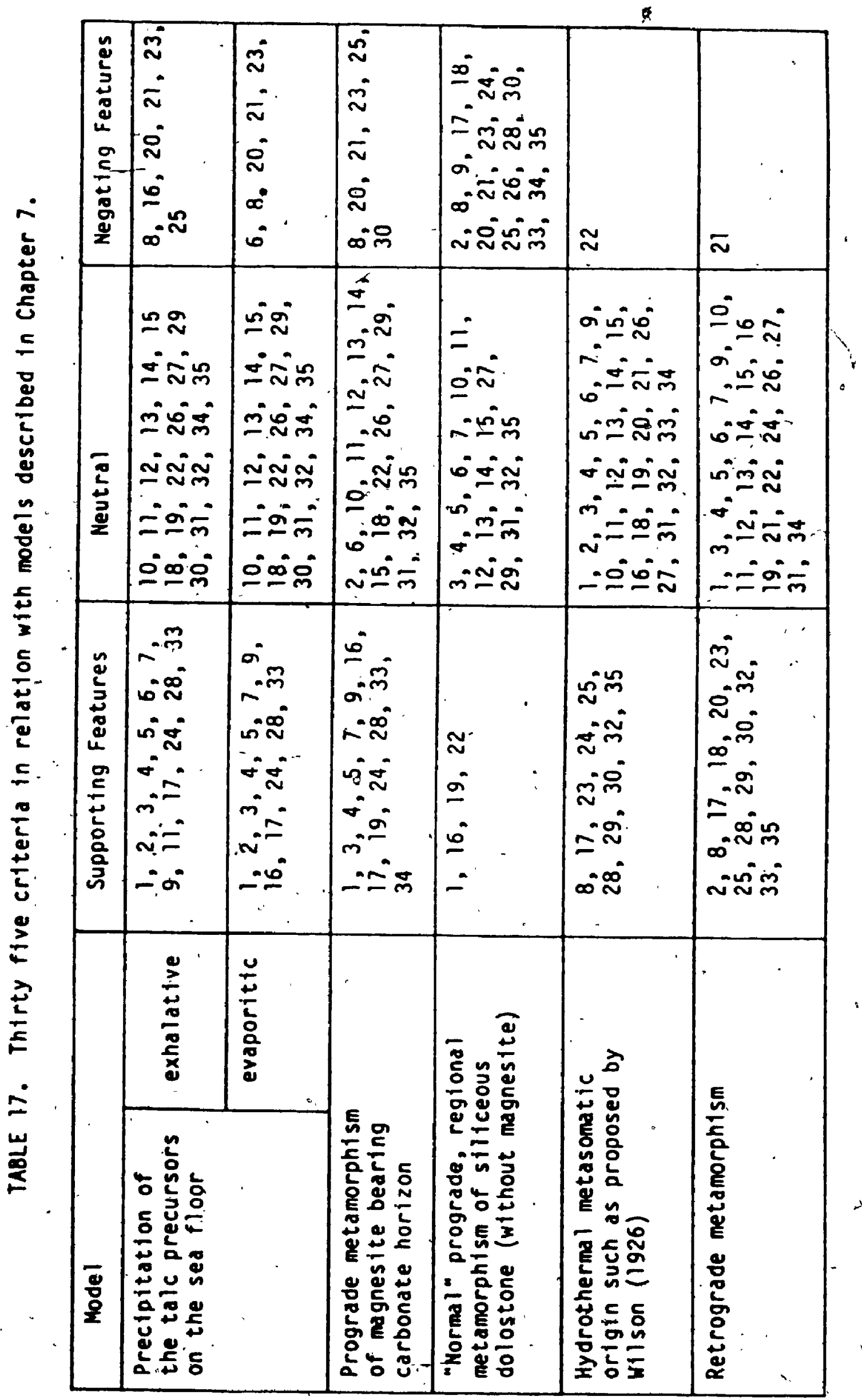


8.2.1 Relations between 35 criterla and genetic models presented in Chapter 7.

Stratigraphic, structura ], morphological, petrological,. mineralogical and geochemical criterions (1-35), enumerated on previous pages, are used to evaluate the applicability of genetic models presented in Chapter 7. The results are recompiled in Table 17.

A major disadvantage of such an approach resides in the possibility, that a "statistically inclined" reader may consider the negative features only. Such a reader may incorrectly conclude, that hydrothermal, vein forming, activity or retrograde metamorphism explain best the origin of talc deposits, because these models correspond to lowest numbers of negating features. A brief discussion of individual models presented in Chapter 7 follows.

8.2.2 Precipitation of the talc or talc precursors on the sea-floor Precipitation of the talc and/or talc precursors on the sea-floor takes place in two distinct environments:

a) in topographic-lows associated with submarine exhalative açtivity

b) In évaporitic basins

These two depositional environments are difficult to distinguish in metamorphosed cárbonates. It is possible that these environments overlap In the Henderson Mine area. Precipitation of the talc and/or falc pracursors on the sea-floor does not explain the following features: sharp and gradual contacts between the statite and the host rock (tremolittc micaceous dolomitte merble) locally discordant contacts between white, coarse, flaky'talc ore and steatite, presence of talc. 


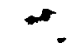

pseudomorphs äfter. tremolite or actinoilte, two generations of tremolite-actinolite solid solution membersh black balc-bearing phyllite, strongly altered remants of dolomite and tremolite crystals in white coarse, flaky talc ore, presence of two texturally distinct types of talc ore, abundance of isobaric divariant mineralogic assemblages and uncommon coexistence of reactant and products, vertical mineralogical zoning. High MgO, low Feo talc is not typical in the hydrothermat'systems related to volcanic activity. On the other hand, this model explains particularly well all the stratigraphic and major morphological. features.

\subsubsection{Metasomatic (vein forming) activity}

Variants of this model were previously proposed for Kenderson-type . talc deposits by Wilson (1926), Spence (1940), Sandomirskg (1954), and Hewitt (1957). External sources of magnesium and silica are required in all these cases (Table 16).

Simple metasomatic talc-forming activity, as presented by above authors does not explain with satisfaction most of stratigraphic criteria and high-MgO/CaO ratio of the flifids required for talc formation.

Retrograde, post-tremolite textures observed in coarse, flaky white talc ore are probably related to a distinct period of post-tremolite metasomatic or metamorphic activity of retrograde nature, since talc pseudomorphs after tremolite occur in talc horizon only.

In situ, sources of magnesium and stlica were proposed for such metasomatic processes as a result of the underground mapping of the - Henderson deposit. "In situ magnestum sources making this hypotbesis more appealing are: 
- primary concentrations of magnesium rich sediments (magnesite,

Wydromagnesite, serpentine, talc, septolite or other talc precursors on the sea floor)

- replacement of dolomite by magnesite* as described and sumarized by Rosenberg and Holland (1964) and Rosenberg and Mills (1966). Magnesium concentrating processes as noted above explain the high $\mathrm{MgO} / \mathrm{CaO}$ ratio, and negative correlation between $\mathrm{CaO}$ and $\mathrm{MgO}$.

Subsequently talc may be formed by several metasomatic or metamorphic reactions which derive magnestum and silica from the protolith of the talc-bearing horizon.

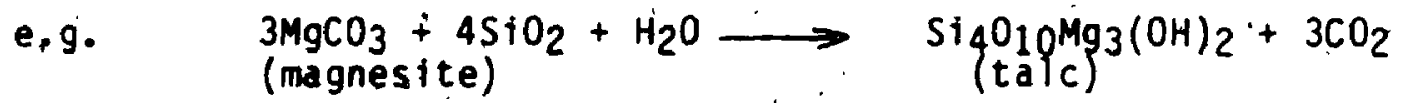

Remants of tremolite and dolomite crystals and absence of calcite withtri coarse, flaky white talc ore indicate that if magnesium was not preconcentrated prior to the talc formation, then calcite was not stable at the tione of talc precipitation or it was leached out later. Abundance of tremolite, dolomite, serpentine and presence of calcite in. traces within steatite, indicate that the host rock did not have a composition of relatively pure magnesite and that reactions other than those presented in Table, 14 must have been involved.

Rosenberg and Mills (i966) summarized their experimental investigatfons explaining replacement of dolomite by magnesite as follows:

"1. Attack of pre-existing do Pomite by $\mathrm{CO}_{2}$ bearing solutions at temperatures below $200^{\circ} \mathrm{C}$ resulting in solutions with a $\mathrm{Ca}: \mathrm{Mg}$. ratio of unity.

2.. Heating of these solutions to temperatures in excess of $200^{\circ} \mathrm{C}$, resulting in the replacement of host rock dolomite by magnesite with production of Ca-rich solutions".

This process does not require outside source of $\mathrm{MgO}$. 
8.2.4 Prograde metamorphism of \$iliceous dolóstone without magnestite Prograde metamorphism affected the Madoc area. (Carmichae), Moore and Skippen 1978.). It contributed thidirectly to the formation of talc deposits; however, normal regional metamorphism of carbonate rocks in presence of high- $\mathrm{CO}_{2}$ fluid cannot explain: presence of serpentine within steatite, two generations of tremolite-actinolite minerals, absence of calcite within coarse, flaky talc ore, widespread distribution of tremolite vs. localized occurrence of talc in the mine area, abundance, of isobaric, divariant, mineralogic assemblages, vertical and horizontal zonations, unusualiy high talc concentrations in ore, high Mg0/CaO ratio, negative correlation between $M g O$ and $C a, 0$, and homogenization in. chemical composition as one approaches the talc deposit.

Serpentine is abyndant and widespread in steatite. It requires the presence of fluid with low mole fraction of $\mathrm{CO}_{2}$ and kigh mole fraction of $\mathrm{H}_{2} \mathrm{O}$ (F+g. 25). Such fluid cannot be derived by devolatilisation of marbles during metamorahism. "However, it may have been derived by devolatilisation of underlying pelitic rocks or nearby sedimentary racks of volcanic origin.

Presence of talc pseudomorphs after tremolite or actinolite, and remnants of tremolite and dolomite wtthin coarse, flaky talc ore cannot be explained by prograde metamöphism.

Two generations of tremolite-actinolite mineryls in black "phyilite" (first strongly altered and second fresh) do not have their equivalents within coarse, flaky talc ore, where all amphiboles are strongly altered. 
Absence of calcite within the coarse, flaky talc horizon cannot be explained by reactions known to occur during prograde metamorphism of stliceous dolostone (Fig. 23) because all of these talc-forming. reactions involve simultaneous formation of talc and calcite.

Reaction 1 of the Table 13 corresponds best to the conditions of regional metamorphism in the mine area. Given optimum concentrations of dolomite and quartz in siliceous dolostone without impurities, this reaction produces a marble containing $56 \%$ talc by weight or $62 \%$ talc by volume. The above talc concentrations are inferior at least by $9 \%$ to talc levels observed in ore of the Henderson deposit (Table 4), without considering dilution factor during mining.

Widespread distribution of unattered tremolite within the mine area is in contrast with altered tremolites within talc horizon, and with the very localized nature of the tảlc-bearing horizon. Conditions that prevalled at the $t$ ime of talc formation are, therefore, related to regional metamorphism onty indirectly or partially.

Abuindance of isobaric.divariant mineralogic assemblages arid uncommon coexistence of reactions and products within. ore and host rock suggest that external buffering (metasomatic activity) took place alang the talc hortzon.

Vertical mineralogical zonation, chemical horizontal zonation, unusually high MgO/CaO ratio, negattve correlation $\mathrm{MgO}$ - $\mathrm{CaO}$, and. homogenization in chemical composition as one approaches the talc deposit are other features that cannot be explained by metamorphism of impure siliceous dolostone, which does not contain magnesite or other magnestum-bearing minerals (of sedimentary or metasomatic origin). 
8.2.5 Prograde metamorphism of magnesite bearing siliceous carbonate The prograde regional metamorphism of a magnesite bearing carbonate bed surrounded by a siliceous dolostone does not explain textural variations in ore, retrograde textures and vertical mineralogical zonation within the deposits.

Presence of two types of talc ore (coarse and flaky without proserved sedimentary textures and second aphanitic and laminated) inditate at least two different processes of talc ore formation. Presence of talc pseudomorph after tremolite-actinolite, and remants of tremolite-actinolite and dolomite within coarse flaky, talc ore are best explained by retrograde metamorphism or metasomatism. Vertical mineralogical zonation withif the depoșit over the distance of less than $250 \mathrm{~m}$ is probably better explained by metasomatic overprint rather than by primary. variation in composition. in the protolith.

The prograde regional metamorphism of a magnesite bearing bed is in agreement with any other criteria listed in Table 17.

\subsubsection{Retrograde metamorphism}

- Retrograde metamorphism is the process whereby higher grade metamorphic assemblages are transformed igho lower grade ones (Winkler 1979).

This definition alone indicates that, in metasedimentary rocks . retrograde metamorphism must be preceded by prograde metamorphism, and cannot be a sole process involved in formation of talc deposits.

Retrograde metamorphism is not related to any of the stratigraphic -features; however, it is the only process that explains the retrograde textures in the ore. It is in agreement with the remaining observations 
(Table 17 ). It is also remarkable that given ideal conditions ( $T, P$, fluid, initial composition of the protolith, reaction may produce ore with talc grades comparable to those reported in Table 4.

\subsection{Additional restrictions}

None of the above genetic models explains all the features of the Henderson type deposits; this combination of above models, is required to satisfy all the 35 criteria.

Before discussing a combined model, some of the criteria will be considered together to obtain addftional restrictions. on the probable -time of talc formation, sedimentary conditions that prevailed during the deposition of the talc horizon, the type of fluids, applicability of closed versus open system and upper temperature limit of the talc formation.

\subsubsection{The time limits on the period of talc formation;}

Features $8,10,11,12,13,14$ and 15 set time constraints on the formation of the talc deposit.

The discordant nature of white coarse, flaky talc ore-steatite contaç suggests that coarse, flaky white talc ore post-dates steatite. (Fig. 27).

Folding and offsetting of talc-bearing horizon suggest that talc deposits were formed prior to final stages of tectonic activity (F1g. 27). .

The above argument is further supported by cross-cutting relationships between talc horizon and late, folded amphibolite and micaceous sulphide-bearing veins. 


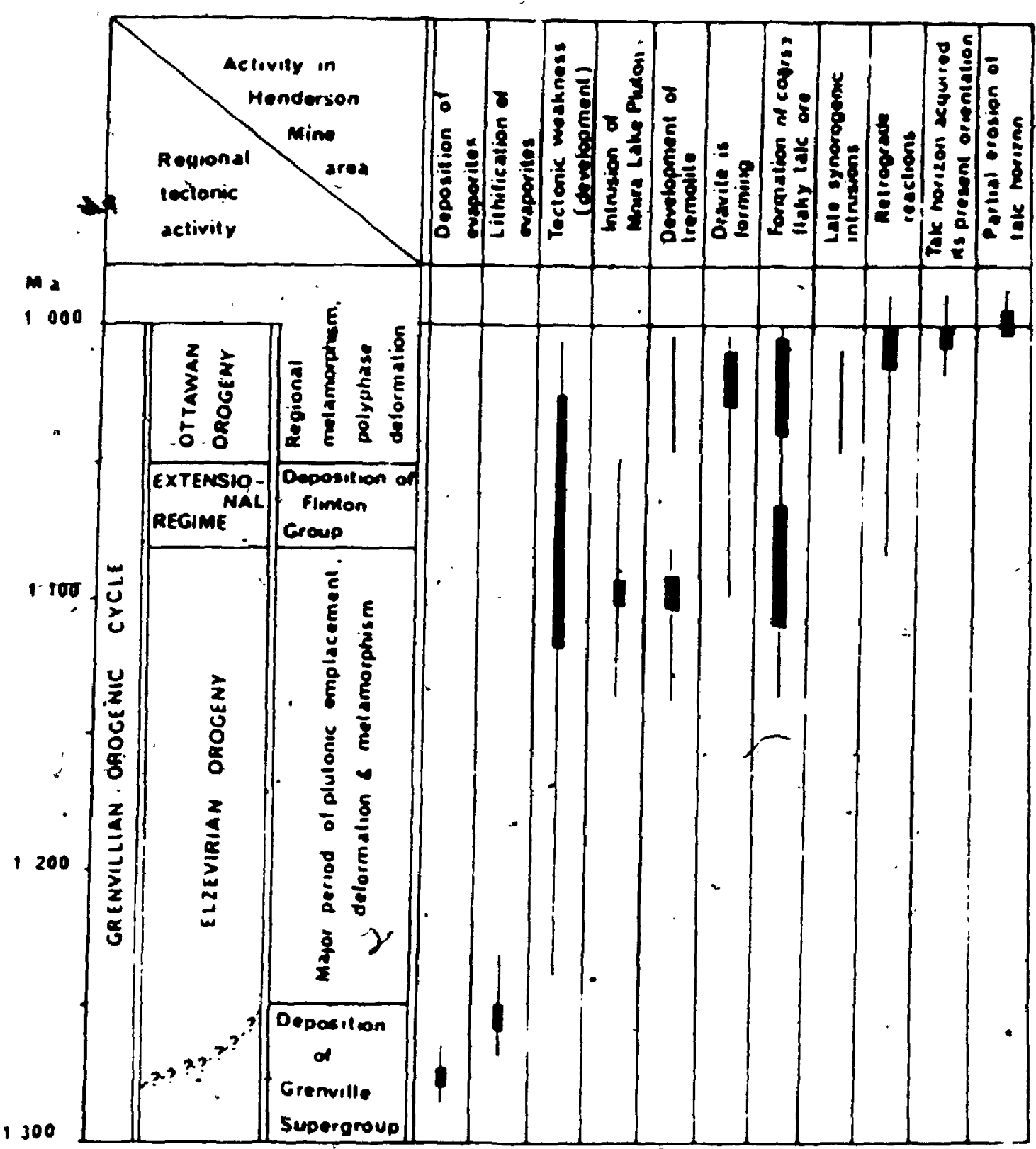

Figure 27. Relative chronology in the Henderson area and its relation to Grenvillitan orogentic cyle. Sources of information:

Moore and Thompson (1980)

Time periods estimated on the basis of information from Batn (1960), Davidson et a l. (1979) and Bell and Blenkins op. (1980). 


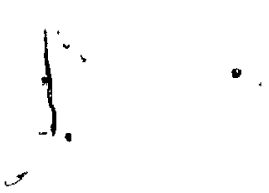

Fresh tremoltte inclusions preserved within dravite phenocrysts indicate that tourmaline crystallized during the period of prograde metamorphism, probably related to intrusion of Moira granite or to ottawen orogeny (Fig. 27). Flattening of dravite porphyroblasts within silicated marbles and orientation of these deformed porphyroblasts parallel to the rock cleavage, suggest that aravite is either pre-deformational or syn-deformational."

Oravite porphyroblasts in talc-bearing rocks are undeformed or less deformed than dravite porphyroblasts within silicated marbles. It suggests that touraline phenocrysts were protected from effects of cectonic stress by suctile medium (talc and/or serpentine). At least some talc and/or serpentine must have formed prior to period of intense tectonic activity associated with ottawan orogeny, unless. two generditons of stratigraphically controlled aravite concentrations exist. in the Henderson Mine area.

8.3.2 Conditions that prevafled during the deposition of the talc protolith

The talc deposits are located within the transition zone between metapelites and wrbles and are assoctated with stromatolites suggesting shallow arine, probably evaporitic environment. The talc deposits are stratigraphically associated with a Zn-Cu stratabound deposit. Cherty bands and dravite-sulphide horizons in simitar environments are considered lateral equivalents of the iron formations assoclated with 3 exhalattre massive sulphide deposits (Slack 1982): An unusualy high.", molcal ratjo is consistent with the information on iron. formations in other parts of the Grenville Province (Gauthter 1982, Gauthter 1981). . 
However, high MgO/CaO ratio may be also exlained by biogenic activity in evaporitic marine environment (Valdia 1968).

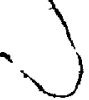

\subsubsection{Closed versus open system}

The transformation of a closed metamorphic system intio an open system, where the composition of the fluids is controlled by iarge external reservoirs is well documented (Kerrick 1974). If the fluids are externally buffered, isobaric divariant assemblages are abundant and the coexistence of reactants and products is unlikely (Rice and Ferry, 1982). Such is the case near the Henderson type talc deposits, Madoc.

The area studied was affected by prograde regional metamorphism (Carmichael, Moore and Skippen 1978). Homogenization of the Bulk chemical composition of the talc ore in. the ared of Henderson deposit (Fig. 19) and absence of coexisting reactants and products may be attributed to equilibration of the rock with large volume of the fluids supplied by large external reservoir.

Other observations supporting these arguments ase: nearly monomineralic nature of coarse, flaky talc ore, locally discordant contact between coarse, flaky white talc ore and steatite, absence of calcite within coarse, white talc ore and gradual increase in the calcite content outward from the deposits, negative correlation between MgO and CaO content (Fig. 17), comparatively widespread distribution of coarse tremolite in the mine area and localized distribution of coarse, white talc ore within the deposits, coexistence of fresh tremolite-actinolite minerals and altered tremolite-actinolite minerals

within black talc ("phyllite") horizon, retrograde textures within white coarse, talc ore and "phyllite". 
8.3.4 Character of fluids and upper temperature limit of the talc formation

Features $17,18,22$ and 26 indicate that fluids present at the time of formation of steatme and of coarse, flaky talc ore were rich in $\mathrm{H}_{2} \mathrm{O}$.

Serpentine wots identified às a major component of steatite and as a minor component of coarse white talc ore. It indicates that ore forming fluid had extremely. low molar fraction of $\mathrm{CO}_{2}$ (Fig. 24; and Table 14). Brucite is also an excellent indicator of low molar fraction of $\mathrm{CO}_{2}$ (Table 14); however, it is very scarce'in Henderson Mine area, and may be related to circulation of post-talc ore filuids only. Quartz-talccalcite assemblage was observed within stromatolitic horizon less than 10 metres from the talc horizon. This assemblage indicates that temperature and mole fraction of $\mathrm{CO}_{2}$ were confined in the; area limited by curves 1 and 2 (Fig. 23). If steatite was formed during prograde regional metamorphism, then quartz-talc-calcite assemblage suggests that temperature remafned under $500^{\circ} \mathrm{C}$. Tremolite and dolomite hosted in steatite, in coarse, white flaky talc ore and in "phyllite" are altered to talc indicating possible variations in fluid composition over a short distance.

The same fluids may be also characterized by considering activities of $\mathrm{SiO}_{2}, \mathrm{Mg}^{++}$and $\mathrm{Ca}++\mathrm{T}-\mathrm{X}$ diagram shows that fluids which formed talc deposits were very. rich in water (Fig. 23 and Table 14). If the temperature of talc formation was inferior to $500^{\circ} \mathrm{C}$, the system was, open, total fluid pressure was low and $x_{\operatorname{co} 2}$ approached- 0 , the system may be approximated by logarithmic activity diagram for $\mathrm{CaO}-\mathrm{StO}_{2}-\mathrm{MgO}-\mathrm{H}_{2} \mathrm{O}$ system, where $2 \mathrm{H}_{2} \mathrm{O}$ is 1 , at constant temperature of $425^{\circ} \mathrm{C}$ and total 

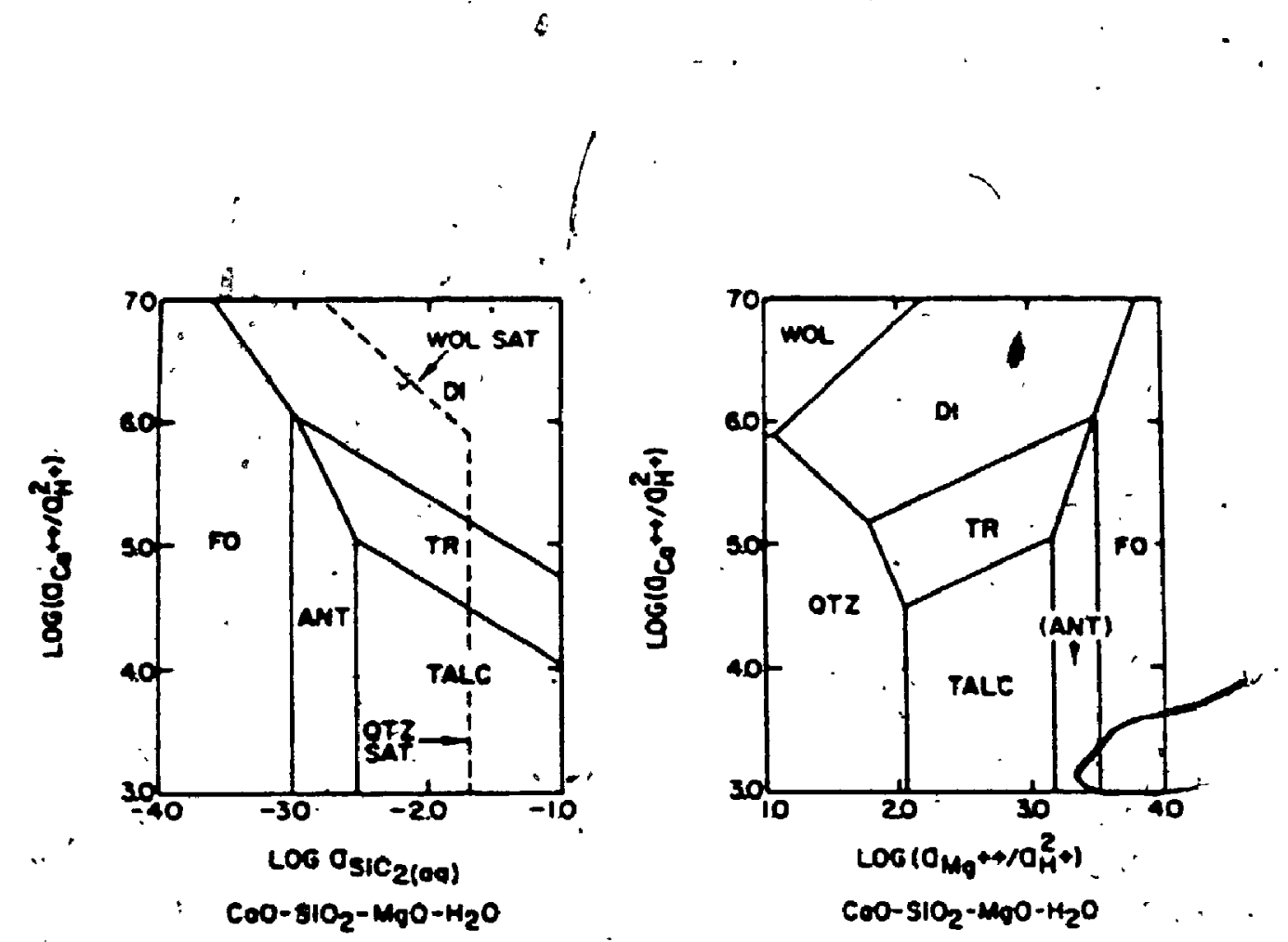

Fig. 28. Logarithmic activity diagrams for the system $\mathrm{CaO}_{2}-\mathrm{SiO}_{2}-\mathrm{MgO}^{2}-\mathrm{H}_{2} \mathrm{O}$ at $425^{\circ} \mathrm{C}, 0.5 \mathrm{~Kb}$ and $\mathrm{a}_{2} \mathrm{O}=$ ? (Frish and Helgeson 1984). 
fluid pressure of $0.5 \mathrm{Kbar}$ (Fig. 28). The diagram shows that steatite could have formed under the conditions where $\log$ a $\mathrm{Ca}^{++} / \mathrm{a}^{2} \mathrm{H}_{+}=5, \log$ a $\mathrm{Mg}^{++} / \mathrm{a}^{2} \mathrm{H}_{+}=3.2$ and $\log \mathrm{aSiO}_{2}=-2.5$, if tremolite, talc and serpentine are in equilibrium (Fig. 28). Zone of coarse, flaky talc ore does contain little or no serpentine and is characterized by high talc concentration. This zone corresponds to higher $\log$ a $\mathrm{SiO}_{2}$, lower $\log$ a $\left(\mathrm{Mg}^{++} / \mathrm{a}^{2} \mathrm{H+}\right)$ and higher $\log \mathrm{a}\left(\mathrm{Ca}^{++} / \mathrm{a}^{2} \mathrm{H+}\right)$ than surrounding steatite (Fig. 28). It is therefore possible that both coarse, white, flaky talc and steatite developed from tremolitic dolomite by metasomatic activity and that mineralogical zoning of the deposit reflects progressive changes in $\mathrm{SiO}_{2}, \mathrm{Ca}^{++}$or ' $\mathrm{Mg}^{++}$activities.

\subsection{Proposed Model}

It is proposed that the talc. deposits were formed by metamorphism and/or metasomatism related to the metamorphism of magnesium-bearing sediments.

The proposed model with or without minor variations satisfied criteria 1 to 35, time limits of the deposit's formation, sedimentary conditions that prevalied at the time of deposition of protore, the nature of the fluids, as well as the passage from an open. to closed system or vice versa.

- The events known to have occurred in the vicinity of the Henderson mine are tentativeiy correlated with major events that affected the Hadoc area. (Fig. 28).

- fluid pressure was probabiy lower than lithostatic pressure if the system was open. 
The weakness of the model is the uncertainty about the. stratigraphic position of the Henderson deposit (Fig. 7) within the rocks of the Grenville Supergroup (Table 1).

The major advantage of this model over the previously proposed models described in Table 16 is that external sources of magnestum and silica are not required.

\subsubsection{Genesis of Henderson deposit}

The consolidation of the Amphibian crystalline basement took place

- at least $1500 \mathrm{m.a}$. abo (Bell and Blenkinsop 1980). Consolidation wds followed by volcanic activity and depositon of
pelitic and carbonate sediments between 1300 and 1225 m.a. ago (Moore and Thompson 19்̣o).

Transition between pêlitic and carbonate sediments consisted of sediments with high $\mathrm{MgO} / \mathrm{CaO}^{\circ}$ ratios. It probably consisted in part of talc, serpentine, sepiolite, magnesite or by hydromagnesite and was, dep'osited in a shallow evaporitic environment.

Synchronously, submarine hydrotherma) discharges (probably related to the latest stage of volcanic activity) deposited thin, cherty sulphide-bearing layers within evaporitic sediments.

Diagenesis, lithification and metamorphism of the magnestum rich, evaporitic sediments and cherty layers took place in the early stages of Elzevirian orogeny (Fig. 27) and resulted in the formation of steatite, which acted as a zone of tectonic weakness during all subsequent event?. "Moira pluton was probably emplaced tn the final'stages of". Elzevirian orogeny (Fig. 27). - 
Geographic assoctation of strengly silicated marbles (coarse-tremolite zones) with granicic rocks (fig. 5), suggests that. coarse tremolite was formed by coniact metamorphism. :

Fine-grained, disseminated tremolite is widespread in the mine area and was probably formed during regional prograde metamorphism (Reaction 2. Table 13).

Regardless of whether boron contained in tourmaline was derived from the sedimentary clays during Elzevirian orogeny or from Moira -pluton, tourmaline porphyroblasts were formed during or before Ottawan orogeny (Fig. 27). The extensional tectonic regime (corresponding to the deposition of Flinton Group within Hastings area) favoured fluid circulation by reactivating old channels (including tectonic weakness colnciding with steatite zone).

The conditions that prevalled at the time of formation of coarse, - flaky talc ore are not well understood. They may be tentatively." approximated by the $\mathrm{MgO}-\mathrm{CaO}-\mathrm{SiO}_{2}-\mathrm{H}_{2} \mathrm{O}-\mathrm{CO}_{2}$ closed and/or open system.

Reactions 1 isted in tables 13 and 14, shown in Figures $24,25,26$ and 27 were considered in order to explain genesis of coarse talc ore. Geological setting, mineralogy, textures, high content of talc and high $\mathrm{MgO} / \mathrm{CaO}$ ratio indicate that no single reaction will satisfy all the. conditions. The combination of the following reactions may have taken place:

$$
\text { . } \underset{\text { (magnesite) }}{\mathrm{MgCO}_{3}+4 \mathrm{SiO}_{2}}+\mathrm{H}_{2} \mathrm{O} \longrightarrow \underset{\mathrm{Mg}}{\longrightarrow}(\mathrm{OH})_{2} \mathrm{Si}_{\text {talc) }}^{\mathrm{Si}_{10}}+3 \mathrm{CO}_{2}
$$


$3 \underset{\text { (dolomite) }}{\mathrm{CaMg}\left(\mathrm{CO}_{3}\right)_{2}+4 \mathrm{SiO}_{2}++\mathrm{H}_{2} \mathrm{O} \longrightarrow \underset{\text { (tale) }}{\longrightarrow}+\mathrm{Mg}_{3}(\mathrm{OH})_{2} / \mathrm{Si}_{4} \mathrm{O}_{10} \mathrm{O}}+3 \mathrm{CaCO}_{3}+3 \mathrm{CO}_{2}$

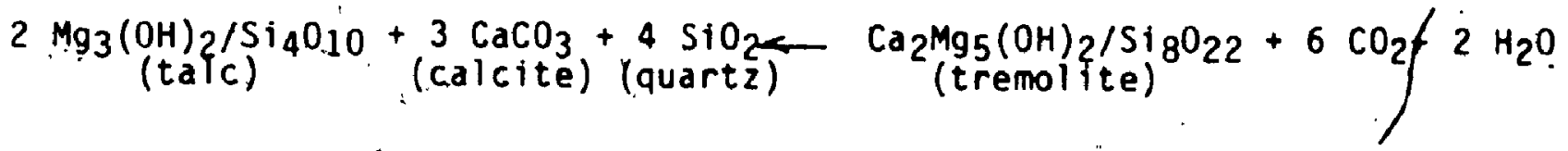

The first metamorphic reaction explains the high $\mathrm{MgO} / \mathrm{CaO}$ ratio and high talc content of the ore and absence of calcite. The second reaction is proposed mainly because of the abundance of dolomite in the coarse ore and the presence of dolomite and quartz in the tremolitic micaceous marble nosting the deposit.

By itself, this reaction could not produce talc ore containing $71 \%$ talc and lacking calcite unless it was accompanied or followed by leaching out of calcite (open system).

The third reaction is retrograde. It could produce talc concentrations comparabiendo coarse, flaky talc ore under optimum conditions, explains retrograde textures wfthin coarse talc ore, but it must be accompanied or followed by leaching out of calcite.

Coarse talc ore could have been also produced, at least in part, by the following reaction where $\mathrm{SiO}_{2}$ and $\mathrm{MgO}$ were derived from the cherty layers and steatite:

$$
4 \mathrm{SiO}_{2}+3 \mathrm{MgO}+\mathrm{IH}_{2} \mathrm{O} \rightarrow \underset{(\text { ta.lc })}{\mathrm{Mg}_{3}(\mathrm{OH})_{2} \mathrm{Si}_{4} \mathrm{O}_{10}}
$$

The fluids with the $\mathrm{H}_{2} \mathrm{O}$ content required to form talc by the first, second and fourth reactions listed above, could have been derived by regional prograde metamorphism from the underlyin sodimentary rocks and/or from sedimentary rocks of volcanic origin (Fig. 7). 
Syntectonic intrustons transected the talc-bearing horizon during terminal stages of the Grenvillian cycle when tectonic and metamorphic activity declined. Pre-Paleozolc uplift, partial erosion of the ." deposits and adjacent rocks, deposition of Paleozolc cap rock, Paleozoic eroston and depsition of unconsolidated Pleistocene sediments succeeded the fermation of talc ore and affected stgnificantly the geological setting of talc deposits. 


\section{REFERENCES}

ALDERMAN, A.R. 1965. Dolomite sediments and their environments in the southeast South Australia. Geochimica et Cosmochimia Acta, 29, pp. $1355-1365$.

ALDERMAN, A.R. and VAN der BORCH, C.C. 1961. Occurrence of magnes.t tedolomite sediments in South Australia. Nature, v. 193, p. 861.

ALDERMAN, A.R. and VAN der BORCH, C.C. 1960. Occurrence of hydromagnesite in sediments in South Australia. Nature, v. 188, p. 931.

ARANITIS, S. 1967. Les gisements de talc pyreneens. Description. Essai d'interpretation de leur genese. Bulletin du bureau de Recherches geologiques et minieres, France, no. 1, pp. 3-118.

BAER, A.J. 1976. The Grenville province in Helikian times; a possible model of evolution. Philosophical Transactions of the Royal Society of London, Ser. A., 280, pp. 499-515.

BAIN, 1. 1960. Geology of the Grenville Bélt through Actinolite, Ontario. Ph.D. thesis, University of Toronto, Toronto, Ontario.

BATES, R.L. 1969. Geology of the Industrial Rocks and Minetals. Dover Publications, New'York, 459 p.

BELL, K. and BLENKINSOP, j. i980. Whole rock Rb-Sr studies in the Grenville Province of Southeastern Ontario and Western Quebec - A Summary Report. In Curreñt Research, part C, Geological Survey of Canada, Popet 80-TA, Pp: $952-154$.

BLOUNT, A.M.' 1982. Mineraloğy of core samples Madöc, Ontario. Unpublished report, Canada Talc Industries Ltd., Madoc, Ontario, $3 \mathrm{pq}$

BODINE, M. 1972. Layer silicates in modern marine hypersaline environment (Abstract). 21 st $c$ lay Minerals Conference, 9th annual Meeting, Clay Minerals Society, p. 19.

BOURQUE, M.S., CROSBY, C.A., DONALDSON, J.A. and MOORE, J.M., Jr. 1982. Algal Stromatolites in the Grenville Supergroup of Eastern Ontario. Joint Annual Meetinğ, Geological Association of Canada, program with abstracts, v. 7,39.p.

BOWEN, N.L. 1940. Progressive metamorphism of slliceous limestone arid dolomite: Journal of Geology, 48, pp. 225-274.

BRICKER, O.P. NESBITT, H.W. and GUNTER, W.0..1973. The stability of -talc: American Mineralogist, v. 58, pp. 64-72.

BROWN, R.L., CHAPPELL, J.F., MOORE, J.M., Jr. and THOMPSON, P.H. 1975. An ensimatic island arc and ocean closure in the Grenville Province

- of southeastern Ontario, Canad Geoscience Canada, 2, Pp. M1-144, 
CAPDECOMAE, L. 1950. Sur la genese des talcs pyrénéens. Bulletin de la Société d'Histotre naturelle de Toulouse, 85, Pp. 313-316.

CARMICHAEL, D.M., MOORE, J.M., Jr. and SKIPPEN,' G.B. Isögrads around the Hastings metamorphic "Iow". In Toronto '78: Field trips guidebook. Edited by. A.L: Currte and W.O. Mackasey, Geological Asspciation of Cánada, pp. 3̦25-346.

COSTA, U.R., BARNETT, R.L. and KERRICH, R. 1983. The Mattagami Lake Mine Archean Zn - Cu Sulfide Deposit, Quebec: Hydrothermal Coprecipitation of Talc and Sulfides in a Sea-floor Brine Pool Evidence from Geochemistry, $180 / 160$ and Mineral Chemistry. Economic Geology: 78 pp.. 1144-1203.

COSTA, U.R., FYFE, W.S., KERRICH, R. and NESBITT, H.W. 1980. Archean Hydrothermal Talc;Evidence for high Ocean Temperatures. Chemical Geology, 30, Pp. 1 1 44-1203.

DAYIDSON, A., BRITTON, J.M., BELL, K. and BLENKINSOP, J. "I979. Regional Synthesis of the Grenville Province of Ontario and western Quebec. In Current Research, Part B, Geological Survey of Canada, Paper T9-18, pp: $153-172$.

DICKSON, A.D. 1981. Canada Tálc Industries (History - Hendérson and Conley Mines to 1951, History from 1951). Unpublished Manuscript, Canada Talc Industries Ltd., Madoc, Ontario, 17 p.

ENGEL, A.E.J. and.WRIGHT, -L.A. 1960. Talc and Soapstone: In Induștrial Miperals and Rocks. Edited by J. L. Gillson, American Institute of Mining Engineers. Inc.; Nêw York, $934 \mathrm{p}$.

EVANS, M.E. Ke26: Report on the Talc Mine of Asbestos Pulp Company of: Madoc, Ontario, Unpublished Manuscript, 9 p.

FORTUMÉ, J.P., GAVOILLE, -B. and.THIBAUL.T, J. 1980: Le gisement de tal.c de Trimouns pres Luzenac (Ariege): Publications, du 26e Congres Geologique International, Paris, Gisements Francais, v. El0, p. 43.

FRISCH, J.C. and HELGESON, H.C. 1984. Metasomatic phase relations in dolomites of the Adamello Alps. American Journal of Science, $v$. 284 , pp. $121-185$.

FÜCHTBAUER; H. and GOLDSCHMIDT, H. 1963. Beobachtungen zur TonmineralDiagenese, Proc. of lst International Clay Conference, Stockriolm, pp. 99-111.

GAUTHIER, M. 1982. Métallogénie du zinc dans la région de MäniwakiGracefiteld, Québec. Ph.D. Thèse, Ecole Polytechnique, Moñtréal, 209 p.

GAUTHIER, M. 1981. Métallogénte du zinc dans la régíon de Maniwaki." Rapport Intérimaire.DPV-753, Ministère de l'Energie et des Ressources, Québec, 24 D. 
GOLDBERG, E.J. and WEHRUNG, J.M. 1981. Analys is of two talc samples by SEM, EDXA. Consultant Report to W.R. Barnes Company "Ltd., Waterdown, Ontario, $18 \mathrm{p}$.

GUITARD, G. 1973. Sur la genese des gisements métasomatiques de talc et de chlorite magnésienne des pyrénées et sur les relations entre le talc et la magnésite. In les Roches Plutoniques dans leurs rapports avec les gites mineraux. Edited by P. Morin. Masson et - Cie, Paris, pp 369-395.

HEWITT, D.F. 1957. Talc Deposit of Canada Talc Industries Limited, Madoc, Ontario. In The Geology of Canadian Industrial Mineral - Deposits, Sixth Commonwealth Mining and Metalfurgical Congress, pp. 240-243.

HEWITT, D.F. 1964.' Geological notes for maps nos. 2053 and 2054, MadocGanonoque area. Ontario Department of Mines, Geological Círcular $12, \cdot 33 \mathrm{p}$.

HEWITT, D.F. 1968. Geology of Madoc Township and the north part of Huntingdon Township, Hastings County. Geological Report 73, Ontario Department of Mines, $45 \mathrm{p}$.

JOHANNES, W. 1969. An experimental investigation of the system $\mathrm{MgO}-\mathrm{SiO}_{2}-\mathrm{H}_{2} \mathrm{O}-\mathrm{CO}_{2}$ - American Journal of Science, 267, Pp. 1083-1104.

KAY, G.M."1942. Ottawa-Bonnechere Graben; Geological Society of Ámerica Bulletin, 53, 585 p.

KERRICK, : O.M: 1974: Review of Metamorphic Mixed-Volatile $\left(\mathrm{H}_{2} \mathrm{O}-\mathrm{CO}_{2}\right)$ Equilibria. American Mineralogist, 59, pp: 129-762.

KROGH, T.E. and DAVIS; G.L. 1968. Geochronology of the Grenville Province: Carnegie Institute of Washingtion, Yearbook 67, pp. 224:-230.

LOGAN, W.E. 1864. On the Occurrence of Organic Remains in the Laurentian Rocks of Canada. American journal of Science, 37 , pp.

- 272-273.

LONSDALE, P. 1978. Submersible exploration of Guaymas Basin: a prelfminary report of the gulf of California 1977 operation of DSV-4 Seacliff. Scripps Institute of Oceanography, Woods .Hole. Massachussets, Ref. șer.., 78-1, p. 16.

LUMBERS, S.B. 1967. Geology and mineral deposits of the Bancroft-Madoc area. In Guidebook-geology of parts of eastern Ontario and western Quebec. Edited by S.E. Jenness. Geological Association of Canada, pp: 13-29. 
MERCOLLI, 1. 1980. Fluor-Vertellung in Tremolit und Tarc in-den metamorphen Dolomiten des Campolungo (Tessin) und ihre phasen petrologische Bedentung. Schweiz. mineral. petrolog. Mitt., 60, pp. $31-44$.

METZ, P. 1970. Experimentelle Untersuchung der Metamorphose von kieselig dolomitischen sedimenten. Contributign to.Mińeralogy and Petrology, 28, pp. 221-250.

MILLER, W.G: and XNIGHT, C.W. 1913. The Rrecambritan "Geology of Southeastern Ontario. Ontario Bureau of Mines, Annual Report, 22, part $Y$ ' $2,151 \mathrm{p}$.

MOORE, J.M. ; Jr. and THOMPSON, P.H. 1972. The Flinton Group, Greniville Province, Eastern Ontario, Canada; In Precambrian Geolegy, Section 1, 24th International Geological Congress, Montreäl, P.Q.,., Proceedings Sect. 1, pp. 221-229.

MOORE, J.M., Jr. and IHOMPSON, P.H. 1980. The Flinton Group: a late Precambrian metasedimentary succession in the Grenville Province of eastern Ontario. Canadian Journal of Earth Sciences, 1.7, pp. 7.685-1707.

OGDEN, D.G. 1987. Mineralogy of Canada Talc Industries Limited. Talc Ore as mined and processed at Madoc, Ontario (unpublished report). Canada Talc Industries Ltd., Madoc, Ontario, $4 \mathrm{p}$.

OSBORNE, F.F. 1931. Non-metallic Mineral Resources of Hastings County, Ontario. Ontario Department of Mines. Annual Report $x \times \times 1 X$, part VI, pp. 22-59.

RICE, J.M. and FERRY, J.M. 1982. Buffering, infiltration and the control of intensive variables during metamorphism. In Characterization of metamorphism through mineral equithbria. Edited by J. M. Ferry. Reviews in Mineralogy. 10, Pp. 263-324.

RICHARDSON, J.A. 1981. Cantal 325. Product data, Canada Talc Industries Ltd., Madoc, Ontario, 1 p.

ROE, A.L. 1975. Talc and Pyrophyllite. In Inqustrial Minerals and Rocks (4th Edition). Edited by S.J. Tefond. American Institute of. Mining, Metallurgical, and Petroleum Engipeers, Inc., New York, $1360 \mathrm{p}$.

ROSCOE, W.E., 1966. Structural control of a Talc Deposit near Madoc, Ontario. B.Sc. thesis, Queer's University, Ontario, $54 \mathrm{p}$.

ROSENBERG, P.E. and HOLLANO, H.D. 1964 Calcite-Dolomite-Magnesite Stability Relations in Solutions at Elevated Temperatures, Science, v. 145, pp. 700-701. 
ROSENBERG, P.E. and MILLS, J.W. 1966. A Mechantsm for the Replacement of Magnesite in Dolomite. Economic Geology, v. 61, pp. 582-586.

SANDOMIRSKY, P. [954. Goology of the Henjerson and Conley Talc Mines, Madoc, Ontario. M.Sc. thesis. University of Western Ontario, London, Ontarto, $128 \mathrm{p}$

SHiROZU, H. 1974. Geology of Kuroko Deposits. Society of Mining Geologists of Japan, Mining Geology Special Is sue 6, pp. 1-9.

SETHURAMAN, K. and MOORE, J.M., Jr. 1973. Petrology of metavolcanic rocks in the Bishops Corners-Donaldson area, Grenville Province, Ontario. Canadian Journal of Earth Sciences, 10, pp. 589-614.

SILVER, L.T. and LUMBERS, S.B. 1966. Geochronological studies in the Bancrcft-Madoc area of the Grenville Province, Ontario. Geological Society of America, Special Publication 87, p. 156.

SLACK, J.F. 1982. Tourmaline In Appalachian-Caledonian massive sulphide deposits and its exploration significance; Applied Earth Science, Transactions section $B$. Institute of Mining and Metallurgy, v. 91, PD. 81-89.

SPENCE, H.S. 1922. Talc, Steatite and Soapstione. Mines Branch, Department of Mines, Ot tawa, Publication Mo. 583.

SPENCE, H.S. 1940. TalC, Steatite and Soapstone. Canada Department of Mines and Resources, Mines and Geology Branch, No. 803, part 1.

TARR, W.A. and KELLER, W.0. 1940. Chert in the Grenville Marble, Ross Jowniship, Renfrew County, Ontario. J Journal of Geolcgy, 48, pp. : i $96-204$.

TILLEY, C.E. 1948: Earlier stages in the metamorphism of siliceous dolomites. Mineralogical Magazine, 28, pp. 272-276.

THOMPSON, P.H. 1972. Stratigraphy, Structure, and Metamorphism of the Flinton Group in Bishops Corners, Madoc area. Grenville Province, eastern Ontario. Ph.D. thesis, Carleton University, Ot tawa, Ont.. 268. $p$.

VALDIA, K.S. 1968. Origin of the Magnesite Deposits of Southern Pithorogarh, Kumaun Himalaya, India. Economic Geology. 63, pp. 924-934.

WILSON, M.E. T926. Talc deposits of Canada: Geological Survey of Canada Economic Geology, Series, No. 2.

WILSON, M.E. 1929. Fluorspar deposițs of Canada: Geological Survey of Canada, Economic Geology Series, No. 6." 
126

-.. WIWKLER, H.G.F, 1979. Petrogenes is of metamorphic rocks (5th Edition). Spritiger-Verlag, New York, 348 p.

WOLLAST, R., MACKEMZIE, F.T. and BRICKER, D.P. 1968. Experimental precipitation and genesis of sepiolite at earth-surface conditions. American Mineralogist, 53, pp. 1645-1662.

WYMME-EDMAROS, H.R. 1972. The Grenville Province. In Variations in tectonic styles in Canada. Edited by R.A. Price and R.J.W. Douglas. Geological Assoctation of Canadz, Special Paper II, pp. 263-334.

ZIEREMBERG, R.A., SHAHKS, M.C. 1983. Mineralogy and Geochemistry of Eptgenetic Features in Metalliferous Sediments, Atlant is II. Deep. Red. Sed. Economic Geology, 78, pp. 57-72.

ZWART, M.J. 1953. La geologie du massif du Saint-Arthelemy: Leidse Geologische mededelingen, 18, $228 \mathrm{p}$ : 
$\square^{\circ}$

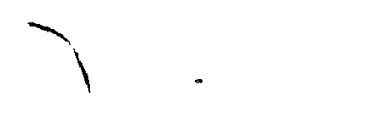

\section{$\Leftrightarrow \quad$ APPENDIXI}

Fteld and Laboratory Investigations

The present study concentrated on three areas:

a) geological mapping and core logging

b) laboratory investigations

c) Itterature search.

The third point does not neeg/ to be described. The field and laboratory investigations are described below.

Field we thods

The fteld tnvestigations were largest component of this work. They were inftiated -in June 1981 and were completed in May 1982 . The fieldwork gay be subdivided into three major components:
a) underground mapping
b) surface mapping
c) core loggting.

Underground mapping

The washing of the back and walls of the drifts was necessary." because a 2 to $3 \mathrm{~mm}$ thick layer of dúst and mud covered the back and the walls of the workings. Underground mapping took place during. the sumer" months of 1981.

Accurate base maps were provided by Canada Talc. Industries Ltd. The 541 foot level (portion of this level was previously mapped by Roscoe 11966) and.new decline were mapped on a scale of 1:360. The chain and carpenters rule were the most useful 
instruments, since significant changes in magnetic field caused by power lines, transformers, railis and pipes made the use of the compass inaccurate in most of the mine workings. The New Conley, third level workings were partly mapped in May 1982.

Sürface mappting

The surface, mapping was done through the autumn of 1981 . The outcrops were located mainiy by careful compass bearings and chatining. Excellent entargenents of aerial photographis of the area were avaflable as weit as a good base map on scale of 1:1200.

Dfamond drilling

Diamond drtliing was fnitiated by. Canada Taic Industries Lto. late in 1981 and completed in May 1982. This diamond driljing was " responsible for the discovery of the East deposit and al'so contributed $\quad \cdots$ to the knowledge of the/stratignaphy in the vicinity of the East déposit.

The locations and elevation of some boreholes were accurately detenmined by transit, but most boreholes represented on figure were located by chain and cómpass bearings.

\section{Laboratory investigations}

Laboratory work consisted of two components:
a) petrological investigations -
b) geochemtca! investigations. 
Petrological investigations

Over fifty thin sections and polished sections of the talc horizon and host rock untts in the mapped area were examined using a polarizing microscope:"

This work was fortified by $x$-ray diffráction and to a limfted extent by qualitative microprobe analysis and mineral staining. This work was performed mainly during March, May and June of 1982 .

In addition SEM and EDXA studies on twö coarse-flaky talc specimens by Goldbera and Wehrung (1.981), X-ray diffraction studies of Blount (1982) and Hicks (1982) were incorporated.

These three latest studies wére ordered and financed by Canada Talc Industries Ltd."

\section{Geochentcal Investigations}

The geochemical study consisted of analysis of the major elements elements. Ten samples of the host rock and talc were submitted to Centre de Recherche Minerale, Sainte-Foy, Quebec.' Concentrations of $\mathrm{SHO}_{2}, \mathrm{MgO}, \mathrm{CaO}, \mathrm{Na}_{2} \mathrm{O}, \mathrm{K}_{2} \mathrm{O}, \mathrm{TiO}_{2}$ and $\mathrm{MnO}$ were determined by Atomic Absorption Spectrometry (AAS). $\quad P_{2} \mathrm{O}_{5}$ was determined by colorimetry. Sulphur was determined by combustion in the induction furnace followed by infrared detection. Precision of the individual analysts is equivalent to a total $98-102 \%$. 
APPENDIX II

Orfentation of the Madoc and queensborough Synclines

The stereographic projections of the,queensborough and Madoc synclines were produced in order to estimate orientation of these major structures.

- The data used for the construction was compiled from Hewitt's (1968) map. Poles. of the beddings were. used in both cases.

Madoic syncline

The plot of poles of the bedding planes from the Madoc area is an equiangular projection. It is based on eight measures only, and therefore'it is highly speculative. At least two concentrations of the poles (along two distinct great circles) may be recognized. It suggets that at least two periods of deformation affected the area. If one is forced to speculate on the orfentation of the madoc syncline based on the above described projection, it may be said that the syncline, plunge steeply: to the East ( $50^{\circ}$ or more towards $N 116^{\circ} E$ ). as indicated by a black dot Pfig. IIa)

Queensborough syncline

The equal area stereographic projection from the queensbo: rough synciltine is based on 30 orfentation measurements of the bedding planes. Meariy peripherical dispersion pattern of the poles of bedding planes", suggests that "type I interforence pattern" af Ransey (1967) is predominant in. the area." 


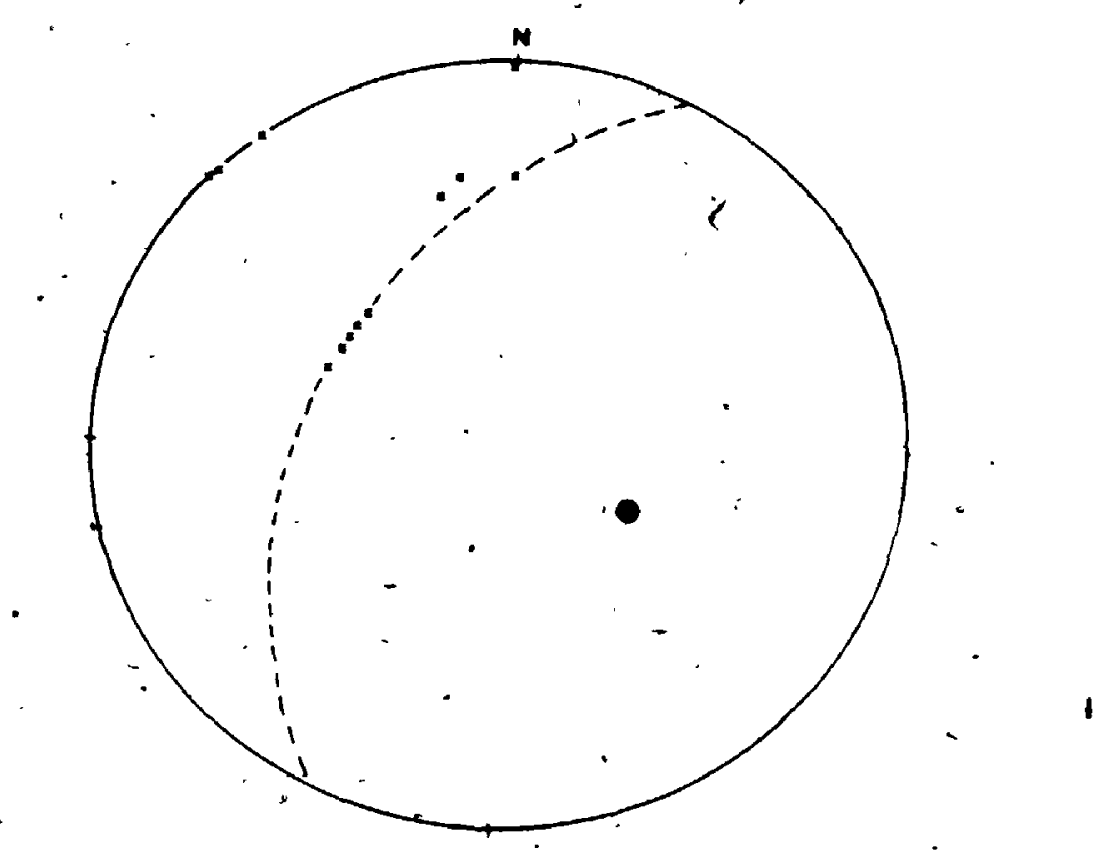

Fig. Ila - Madoc syncline poles of the bedding planes. ( $x$ - poles of the bedding planes; - folld axis)

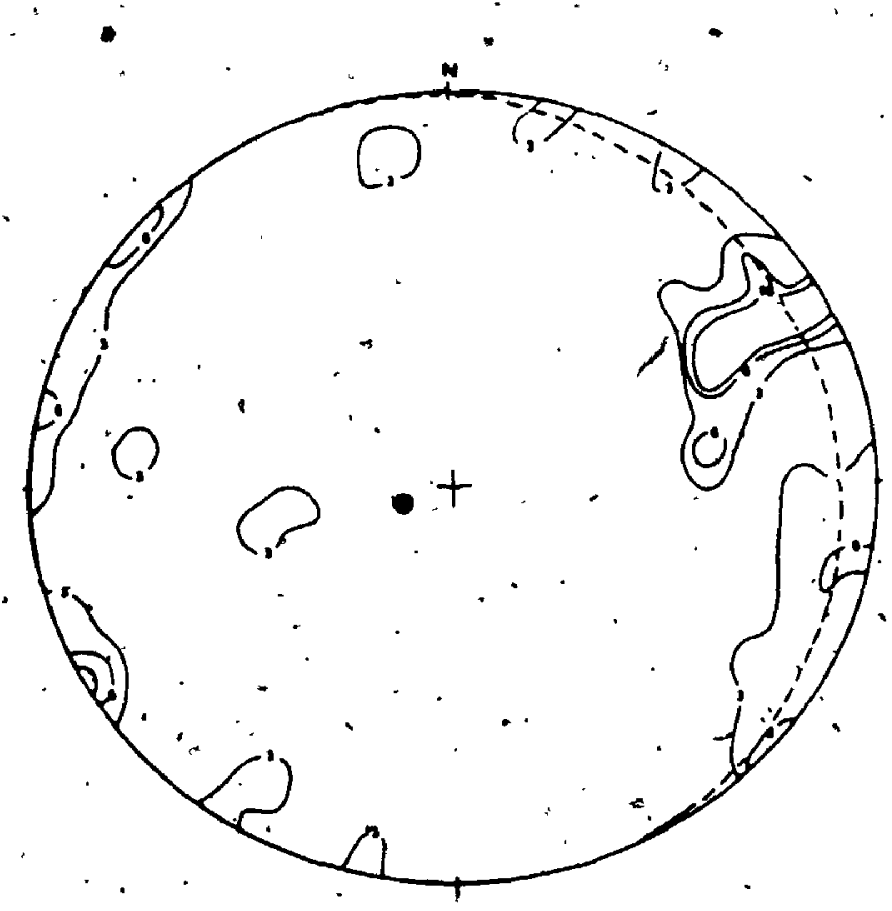

Fig. IIb - Queensborough syncline (poles of the bedding planes contoured; $N-30$ ). Peripheral dispersion pattern of poles of bedding planes. 
132

The variability in the plunges of the poles of the bedding that axes of $F_{1}$ (folds related to $D_{T}$ ) are affected by subsequent deformations - Black dots indicate the plunge $\left(80^{\circ} \longrightarrow\right.$ $N 254^{\circ} \mathrm{E}$ ), of the axis (fig. II)

N.B. It is impossible to determine from these diagrams, if two or. - more major periods of folding affected the area. Tectonic style of the area is described in the main text. 


\section{APPENDIX III}

\section{Descriptions of Thin Sections}

\section{Abbreviations used in thin section descriptions}

ak actinolite
ap apatite
ab albite
bj biotite
ca calcite
cb carbonate
ch chlortte
do dolomite
di diopside
gf graphite
hem hematite

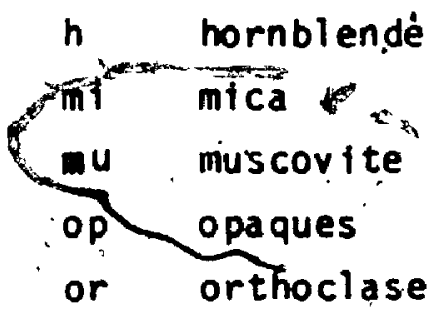
pl phlogopite
pg plagioclase
py pyrite.
po pyrrhotite
q. quartz
ru rutile
sup serpentine
sc silica
sp sphalerite
ti sphene
$s:$ sulphides
the tale
t.l tourmaline
tr tremolite
um vermiculite
zo. zoisite

Major minerals ( $>5 \%$ ) are listed in front of the oblique; minor and accessory minerals are listed after the oblique.

( $)$ not positively identified

$\dot{A} \rightarrow$ B mineral A alters to mineral $B$. 


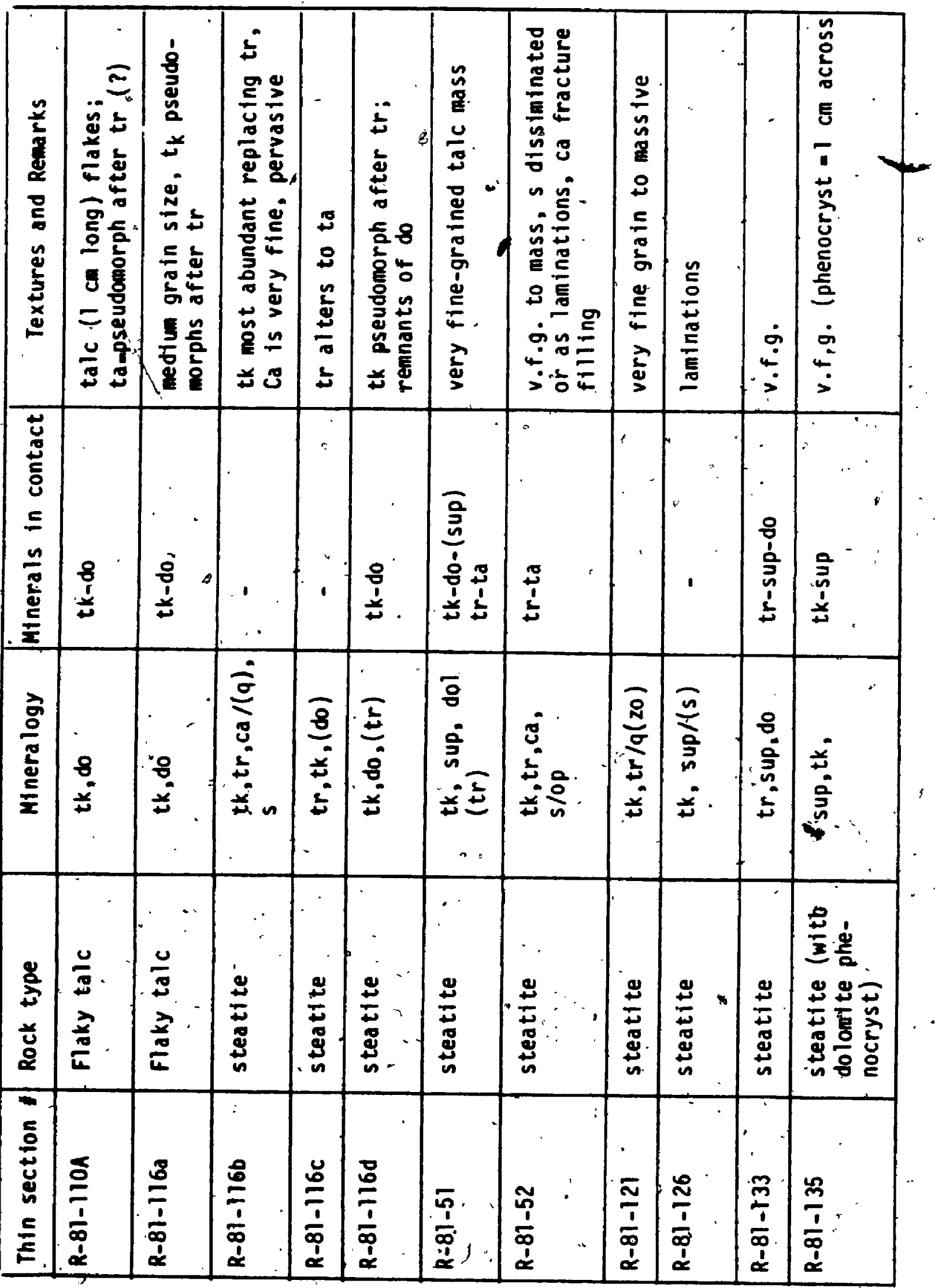




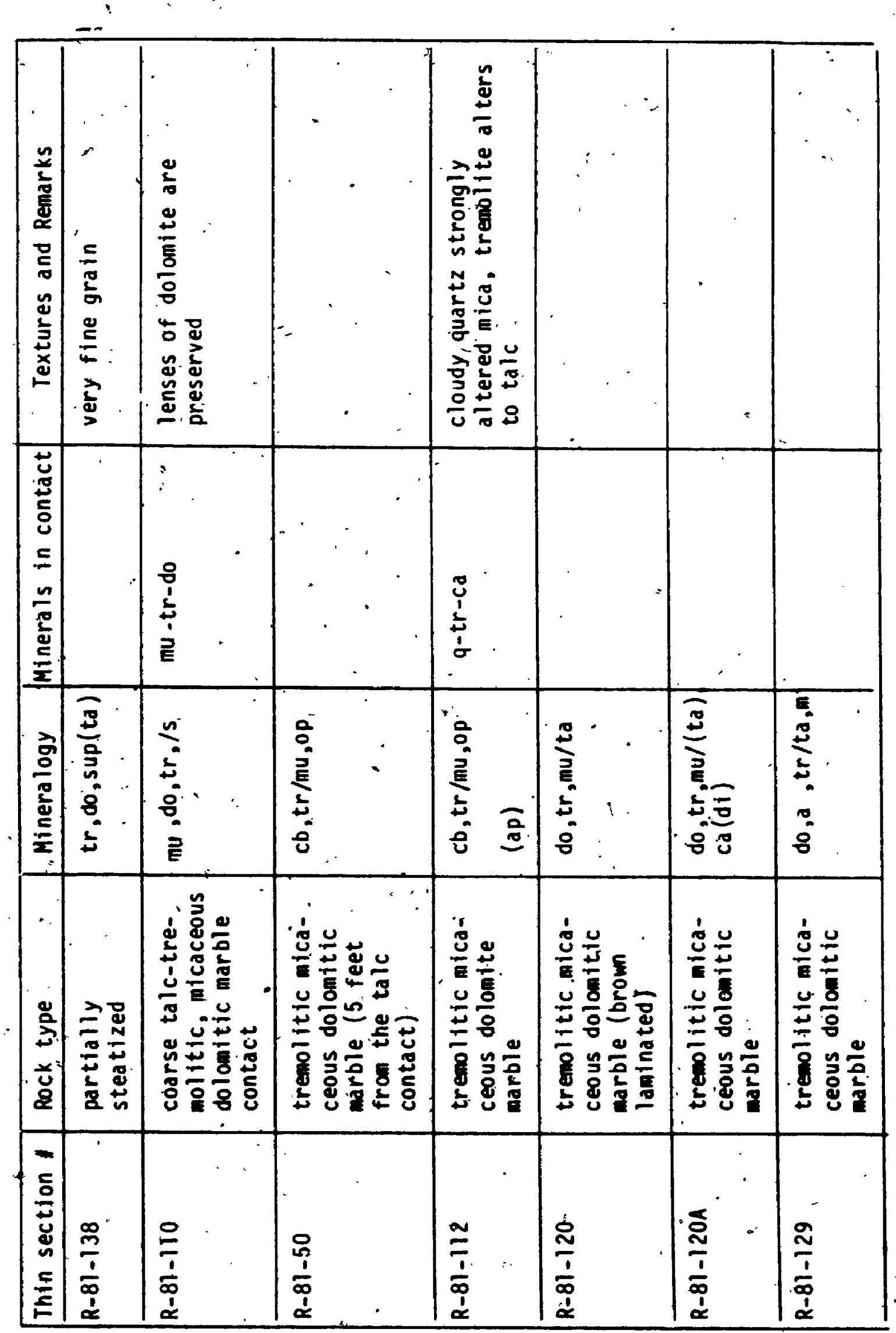



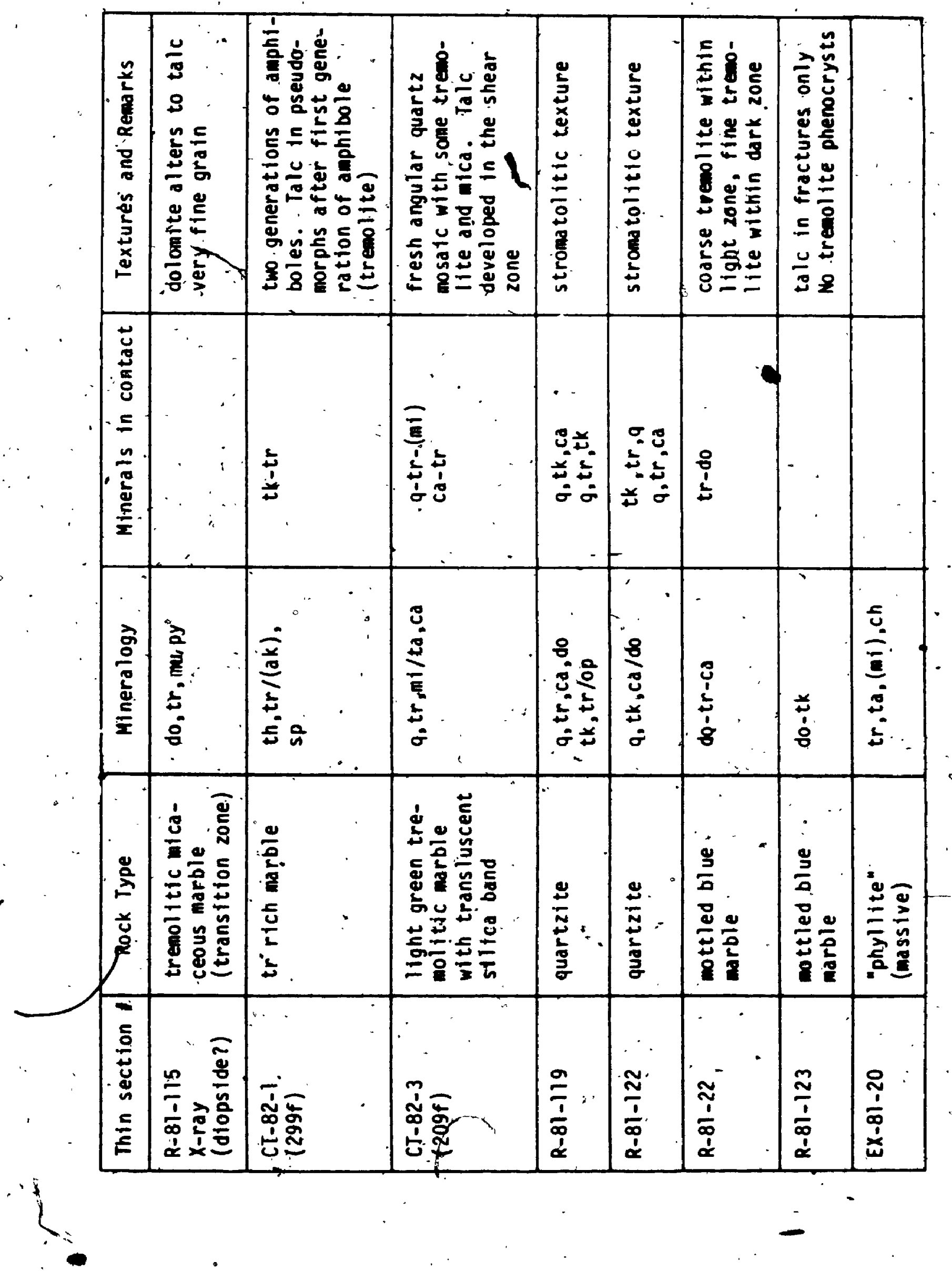







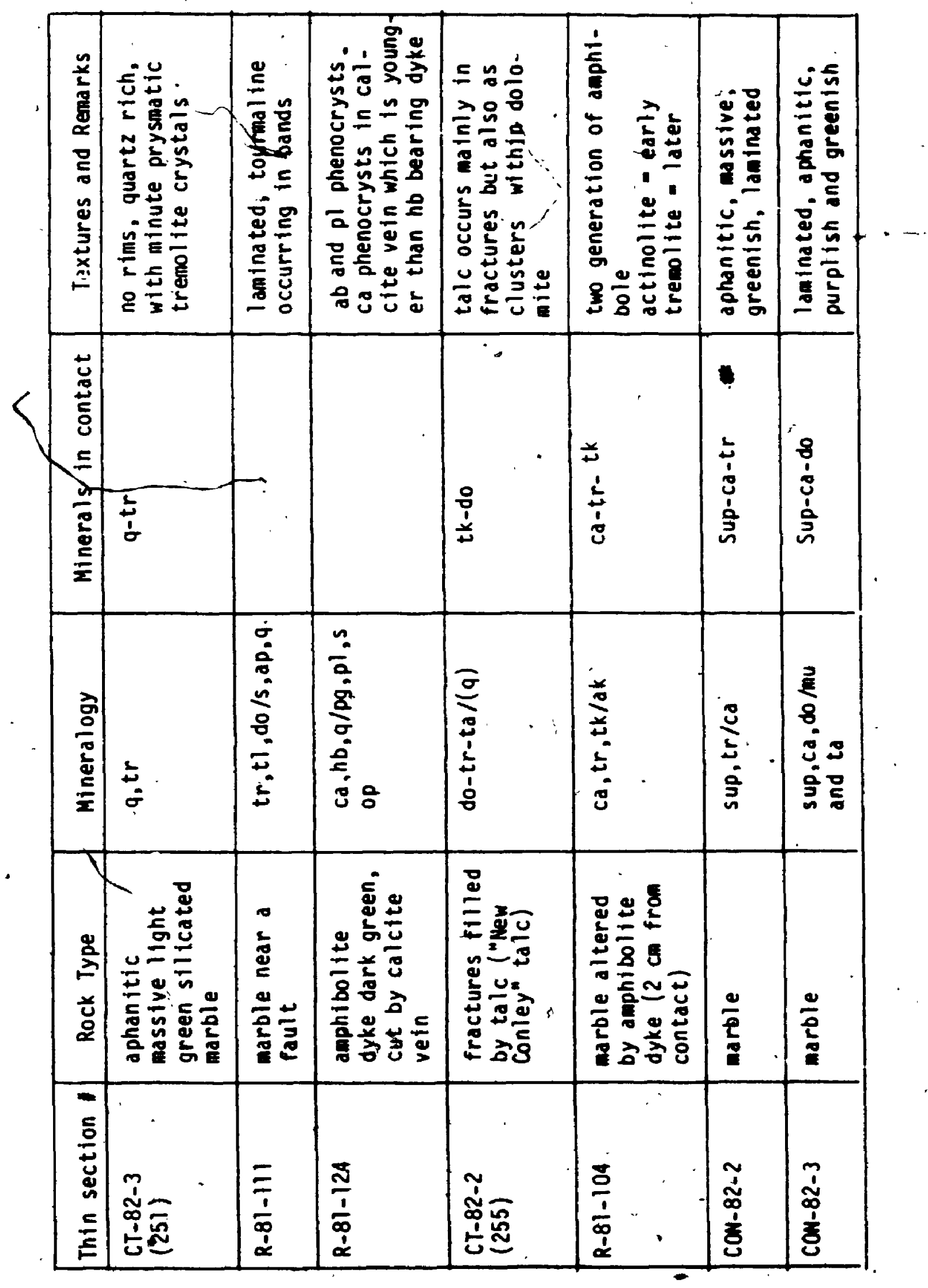




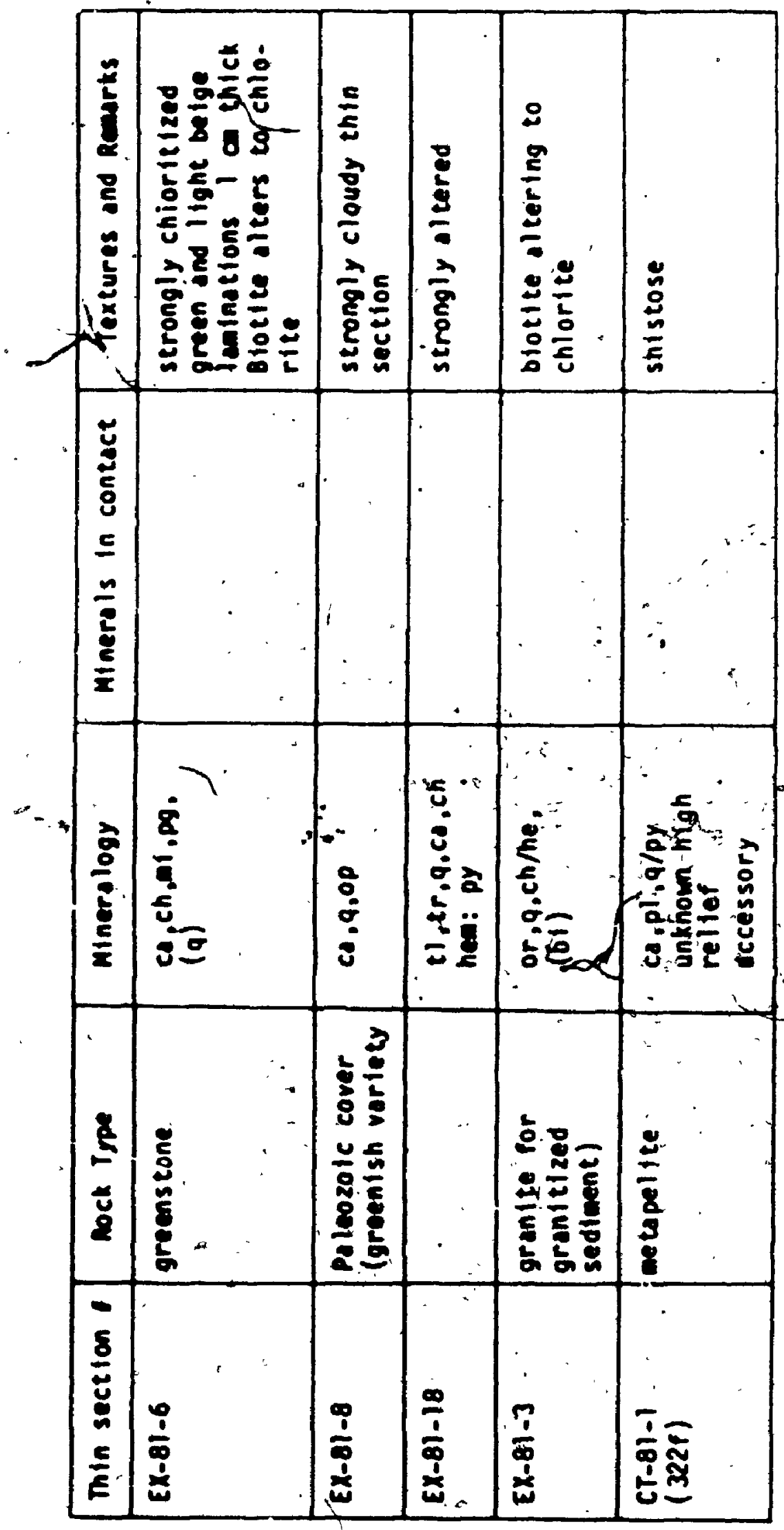

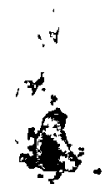


APPENDIX IV

141 
142

Lit tho logy

9 : dykes

8 undifferentiated marble

7 stromatolitic dolomitic quartzite

6 "mottled blue" marble

5 tremolftic micaceous, dolomitic marble (hanging wall).

4 talc ore (Ha steatite, tb coarse flaky ore)

3 partly steatized tremolitic micaceous dolomitic marble*

2. tremolitic micaceous dolomitic marble. (footwall)

1. "Phyll1te"

traportant from the engineering and economic view points.

Other symbols :

$\therefore$ Winze or shaft
$\because$ excavation
$\therefore$ geological contacts 


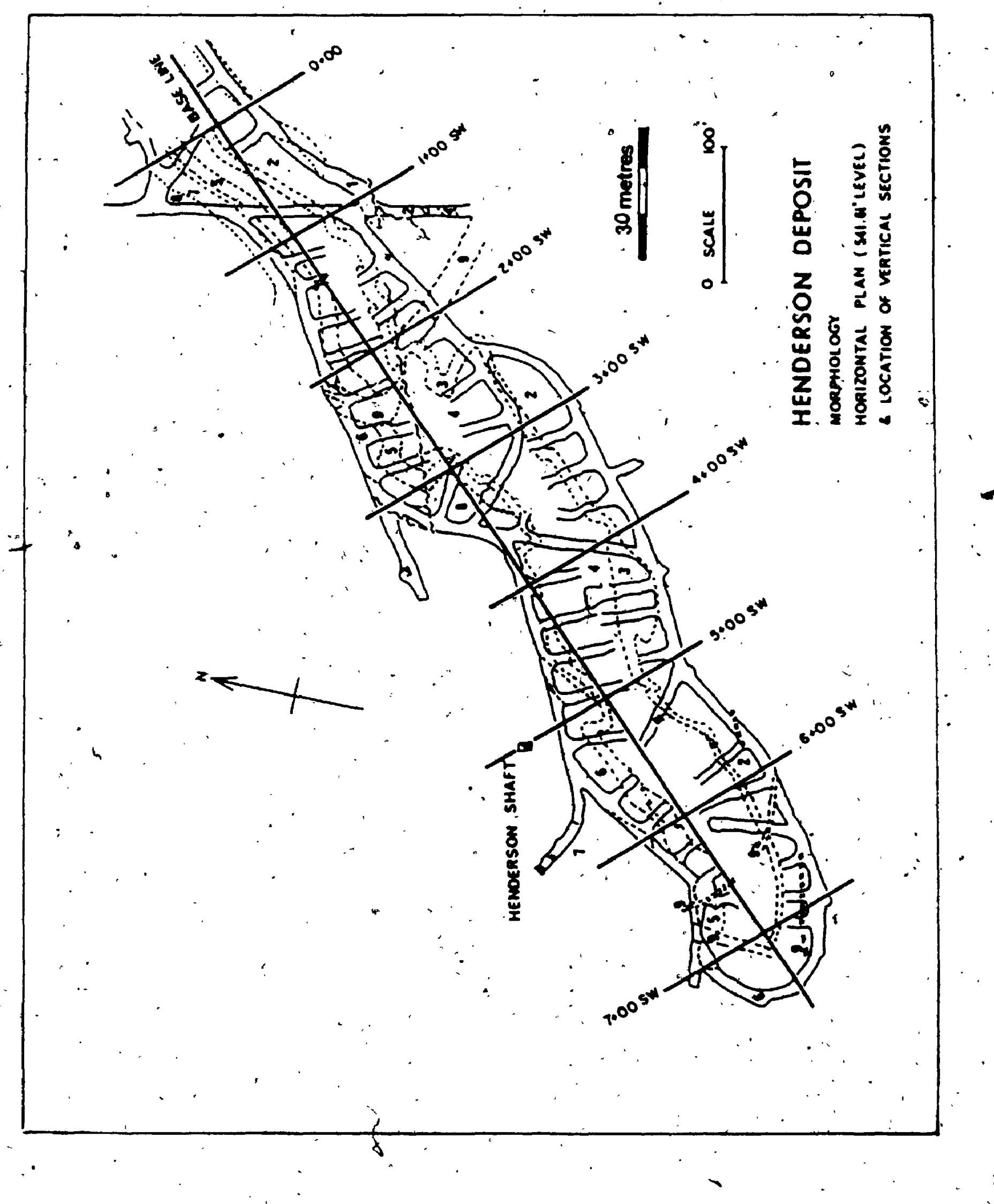









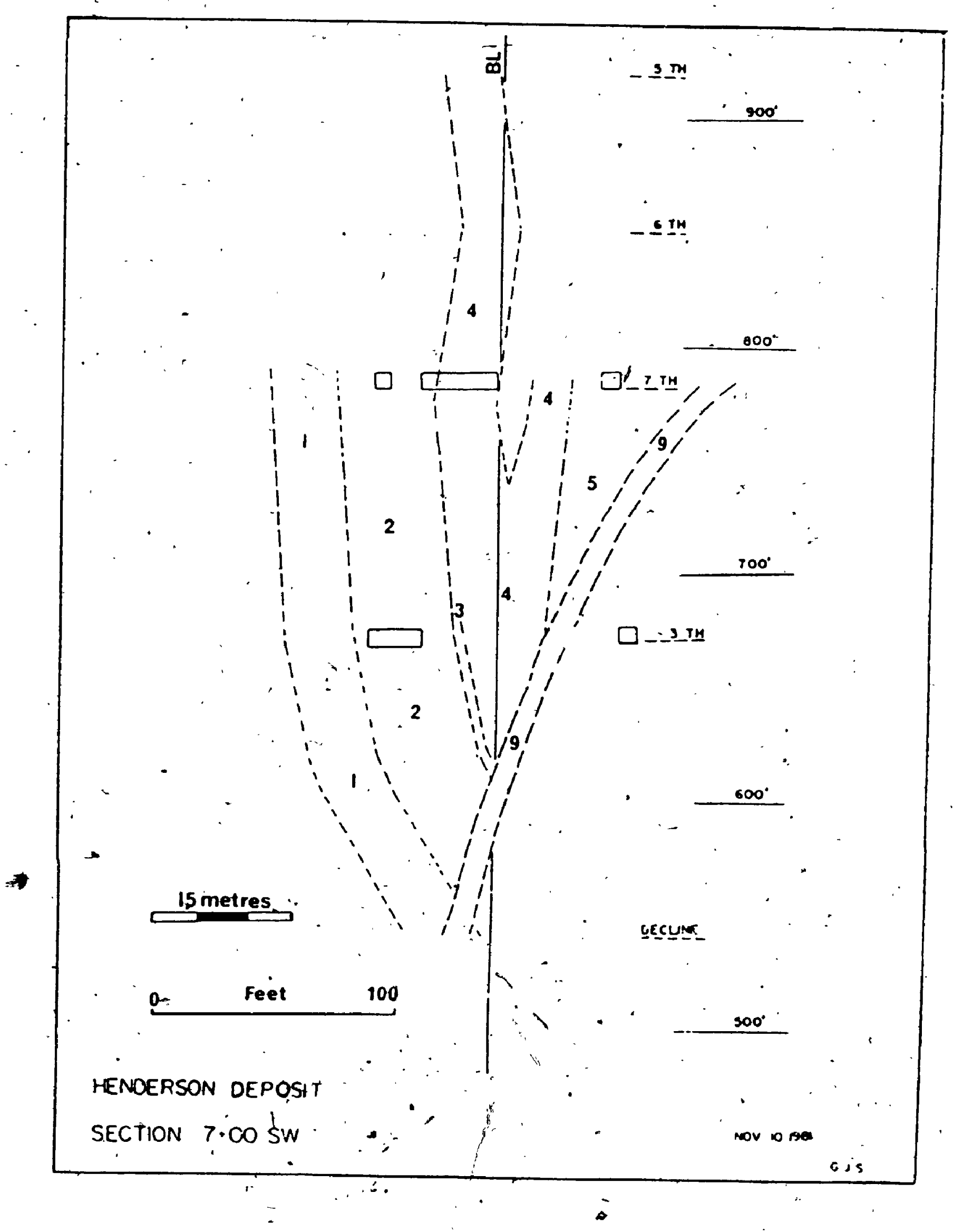




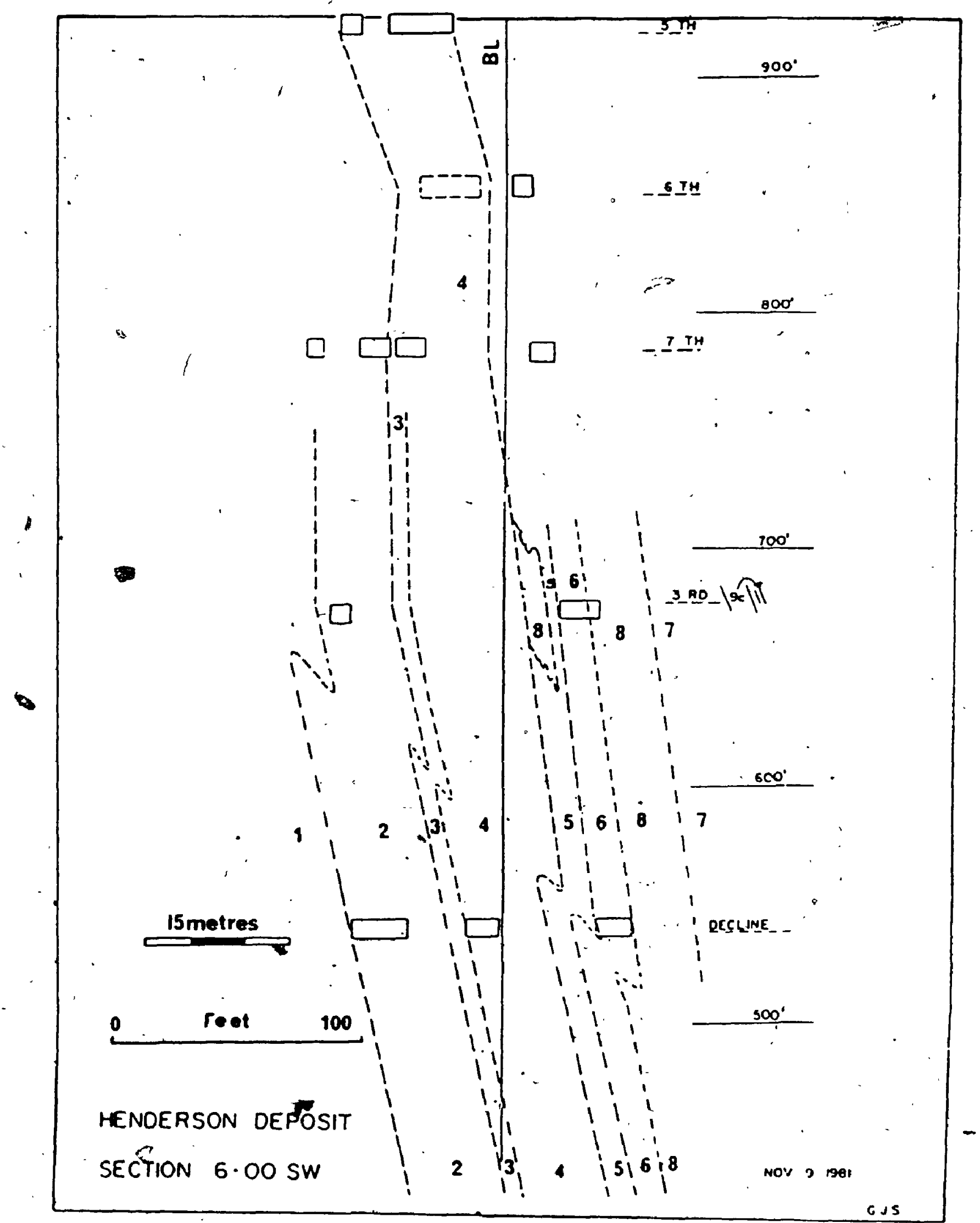




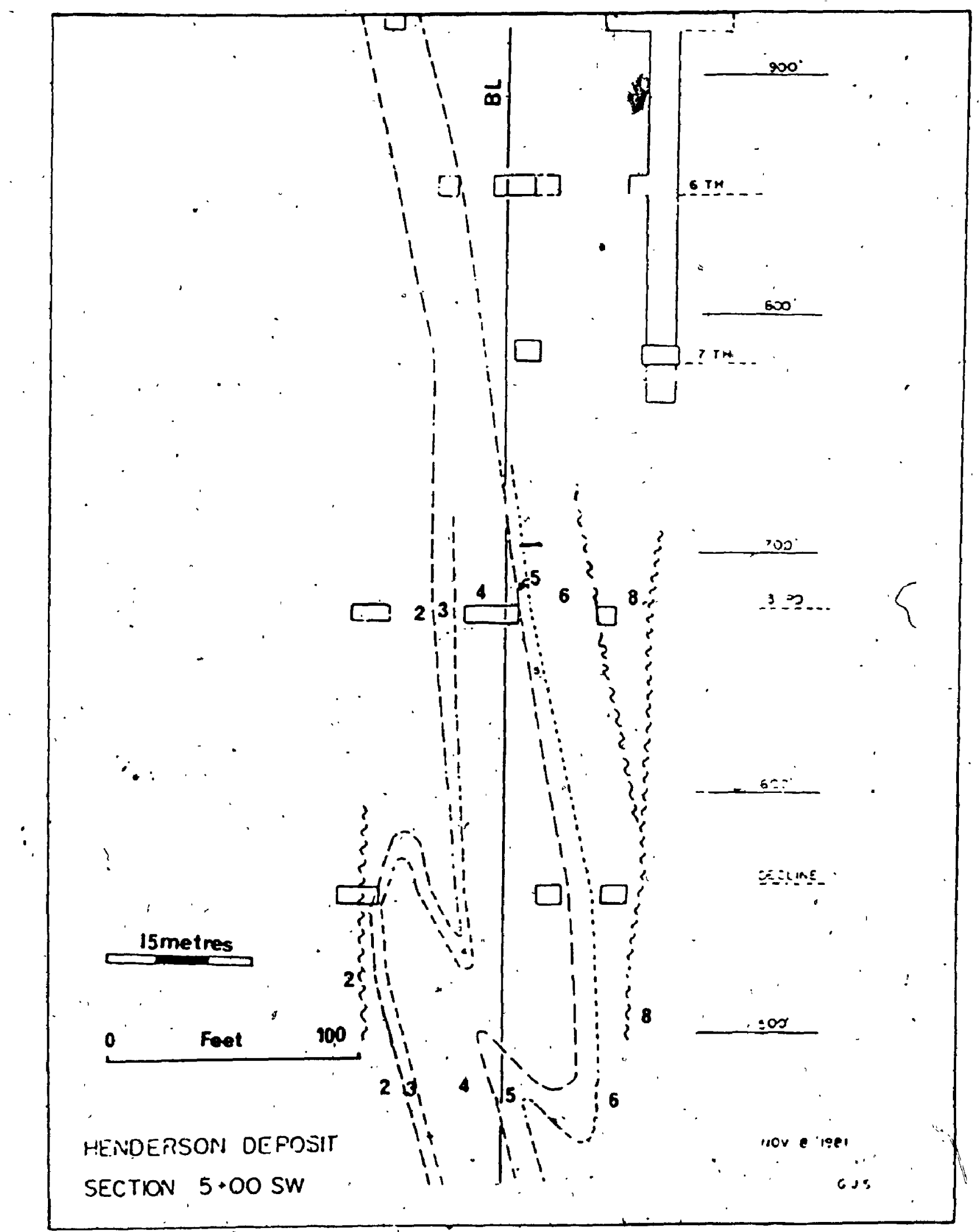


0

149

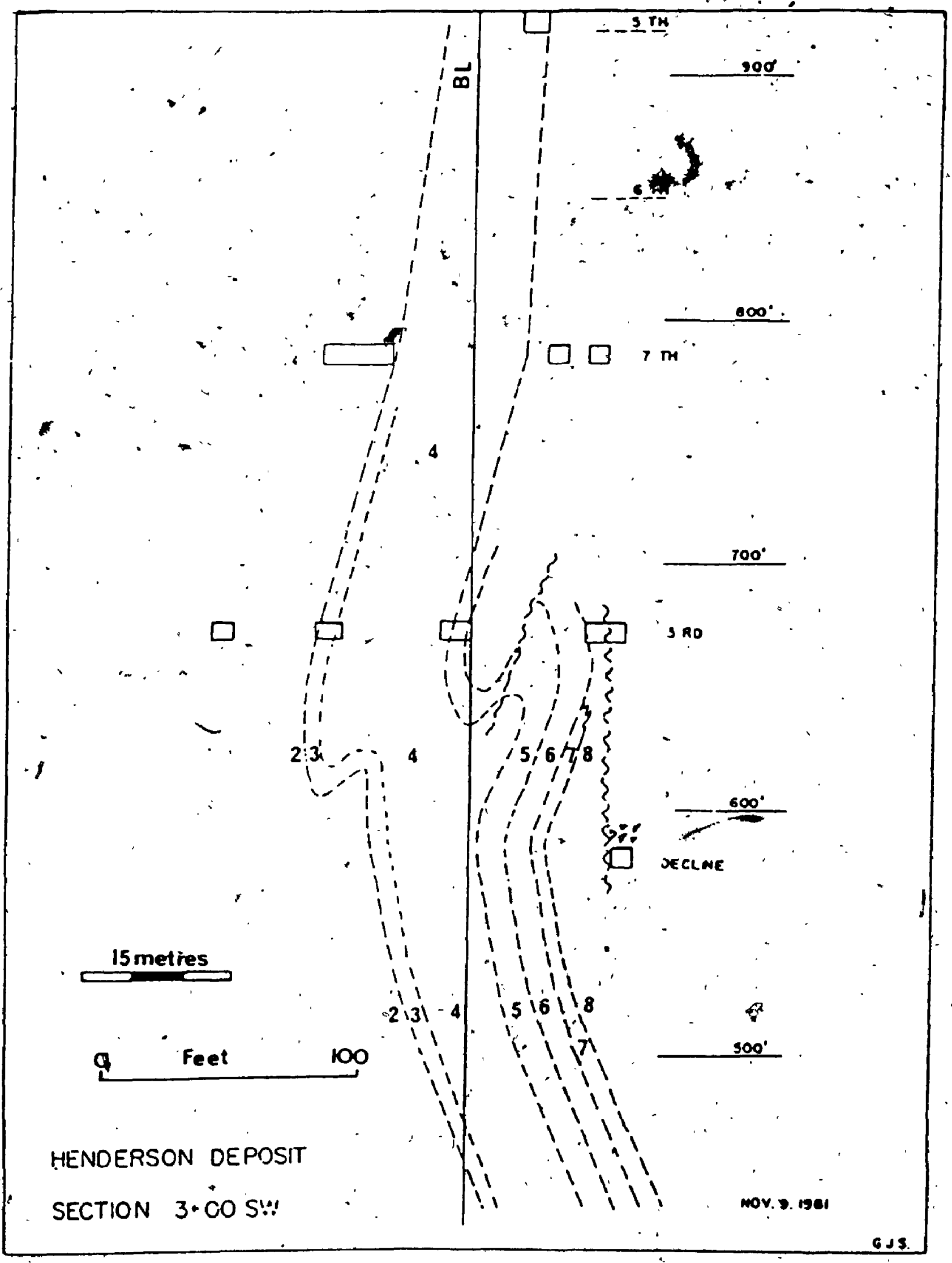




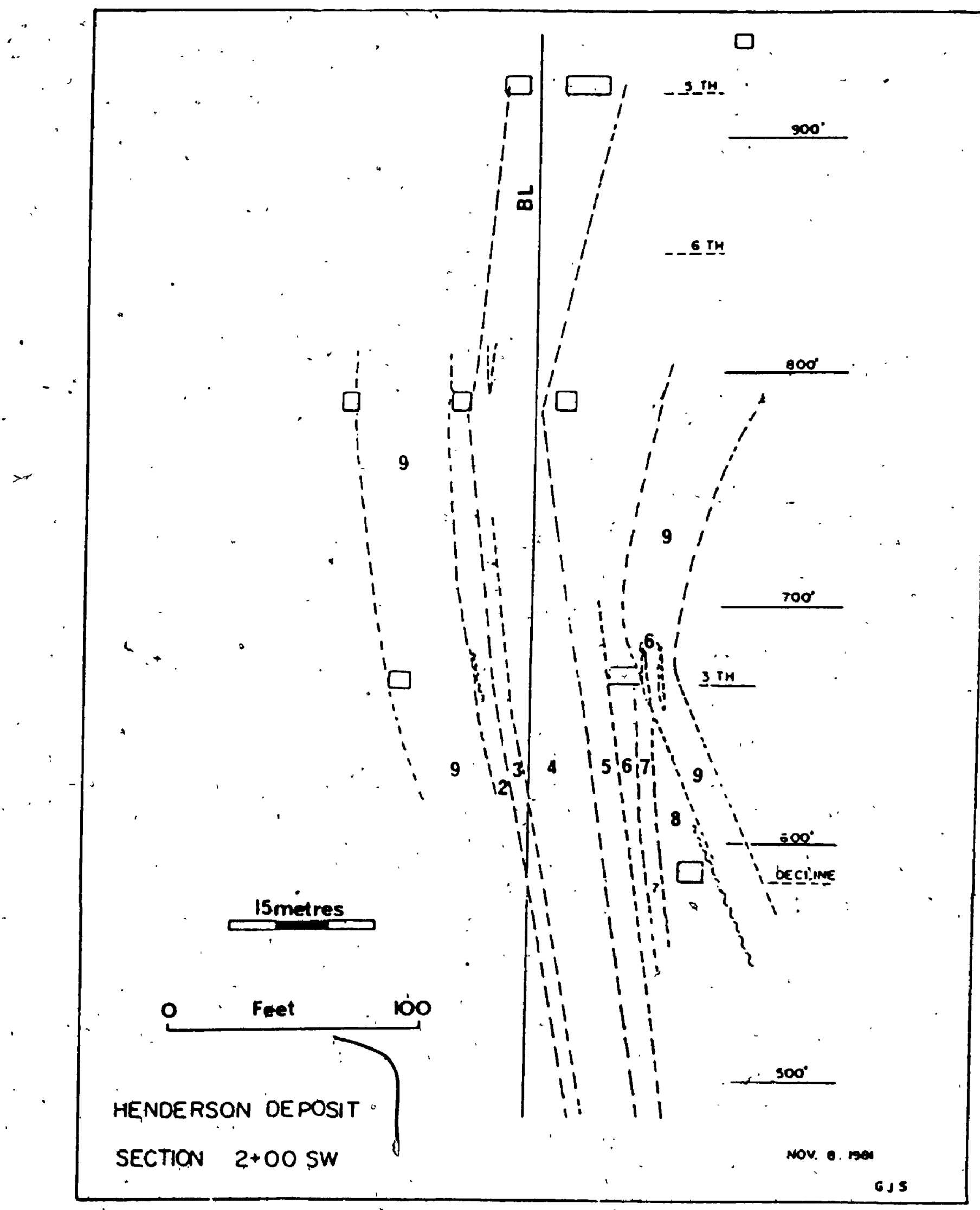

2 


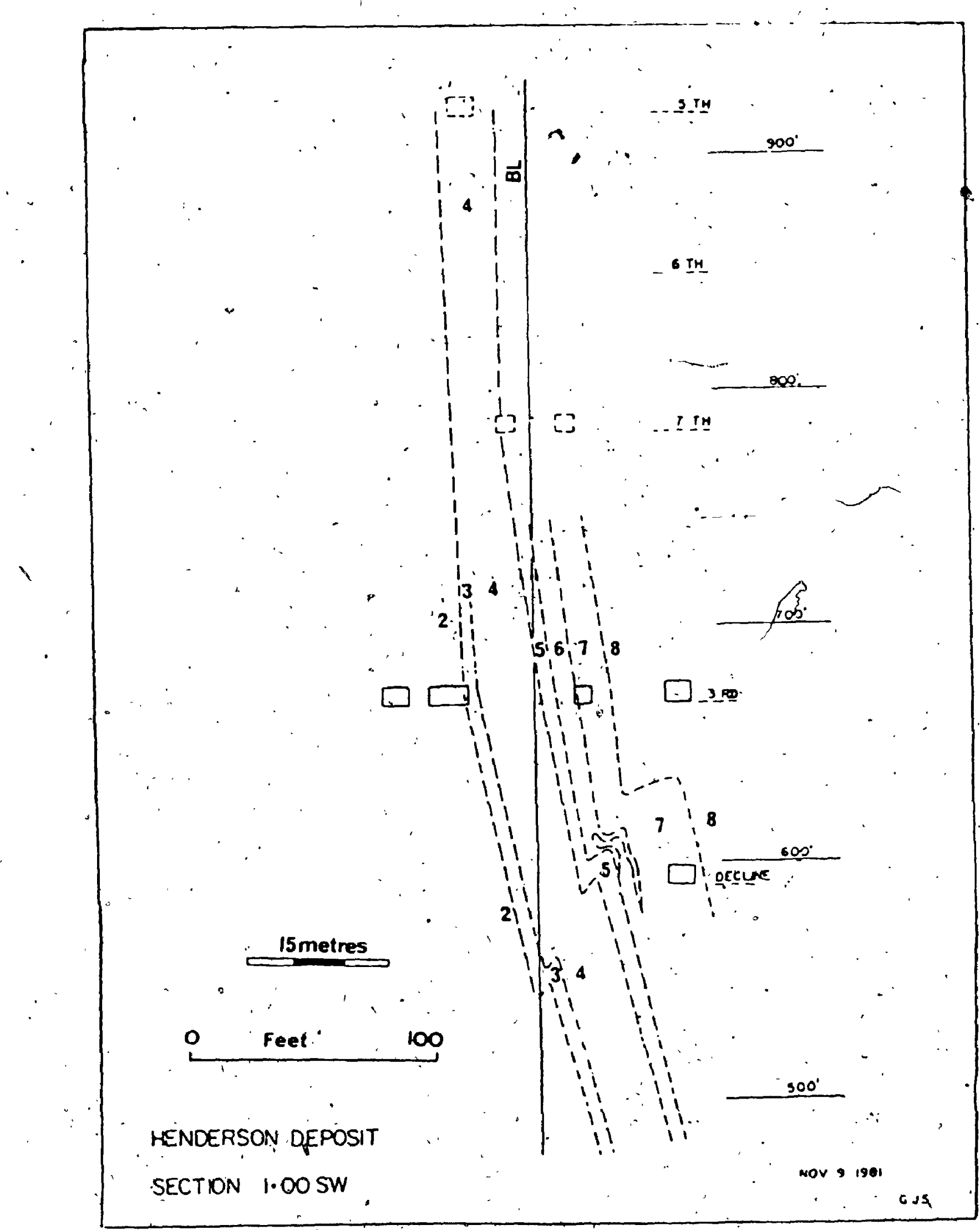


$1 \overline{52}$

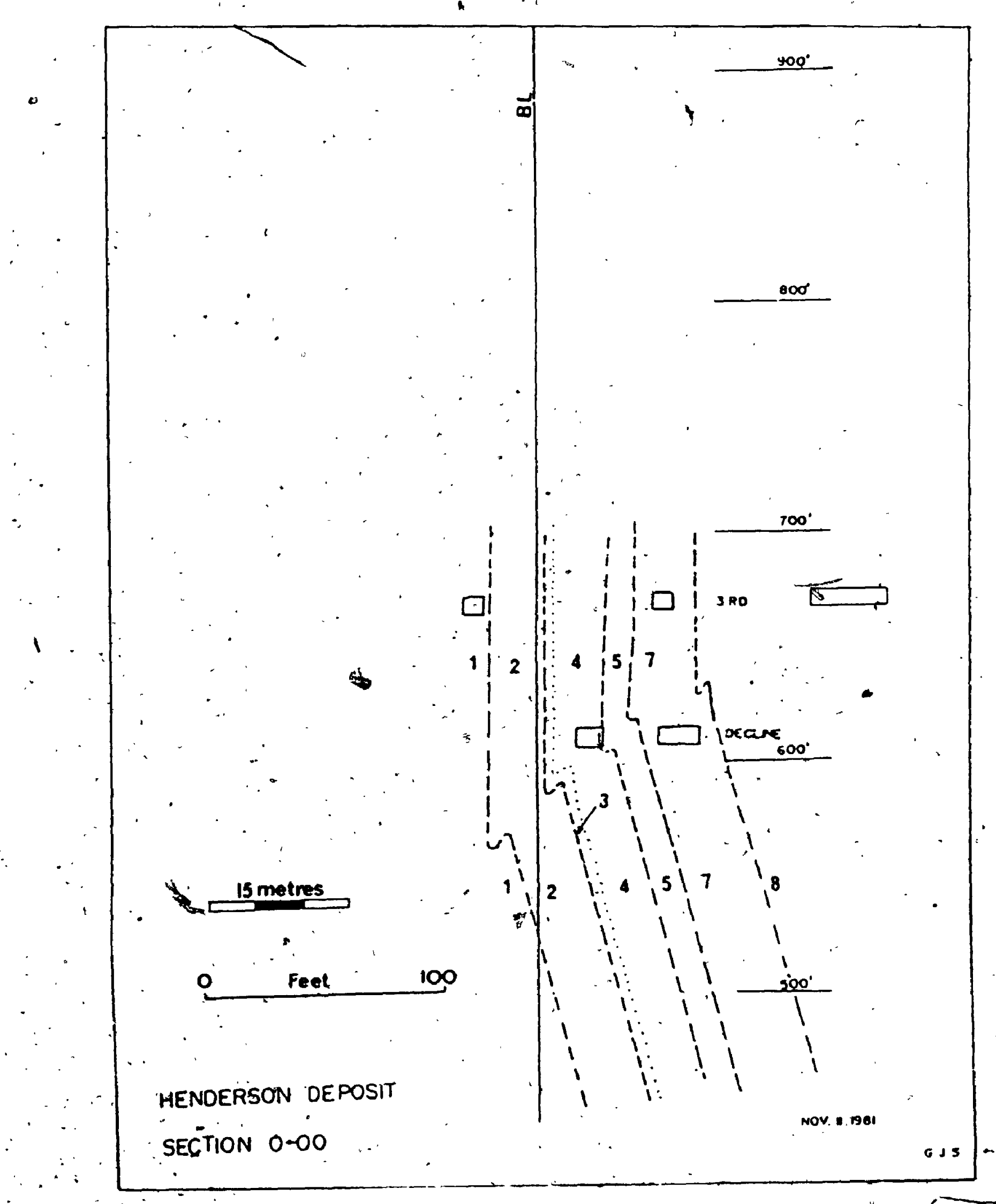




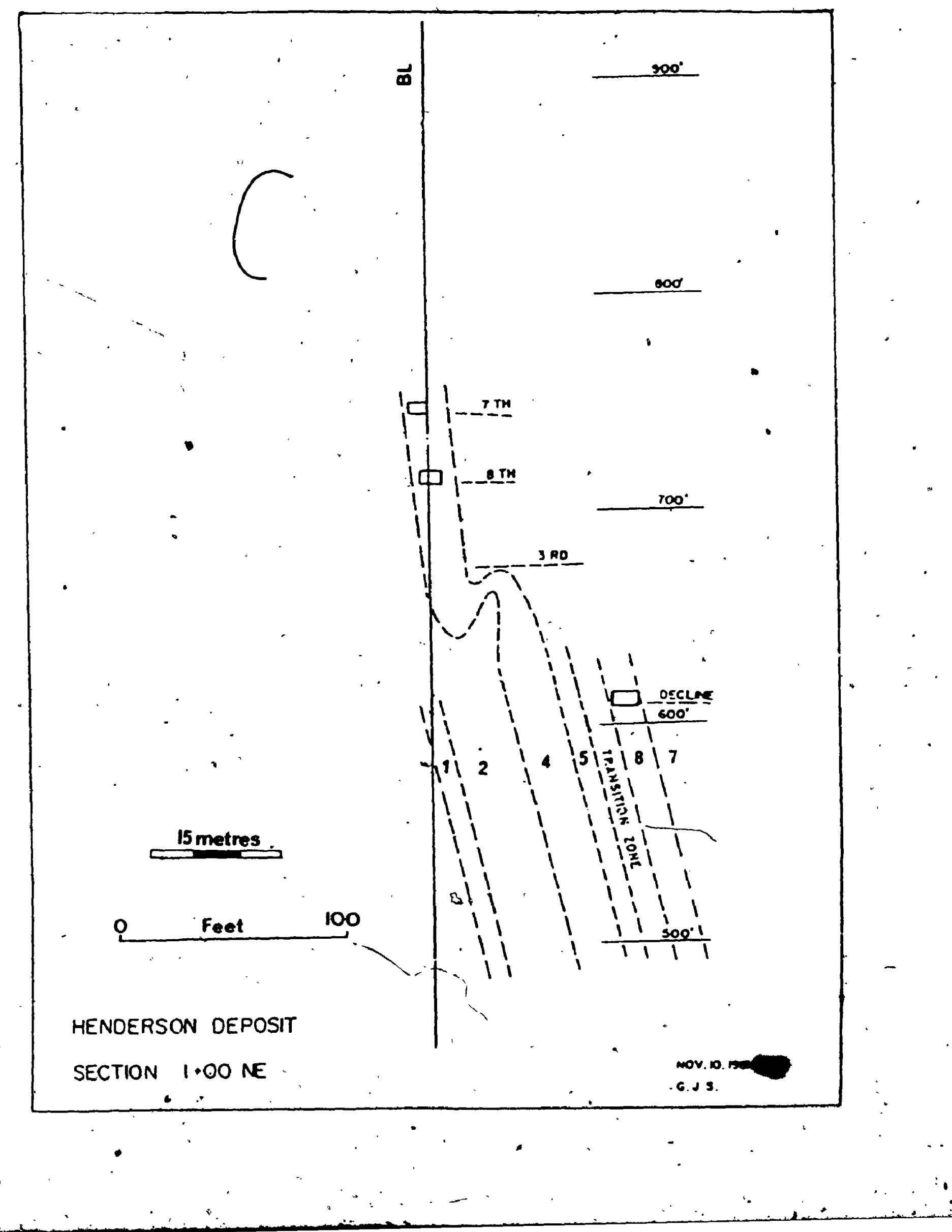




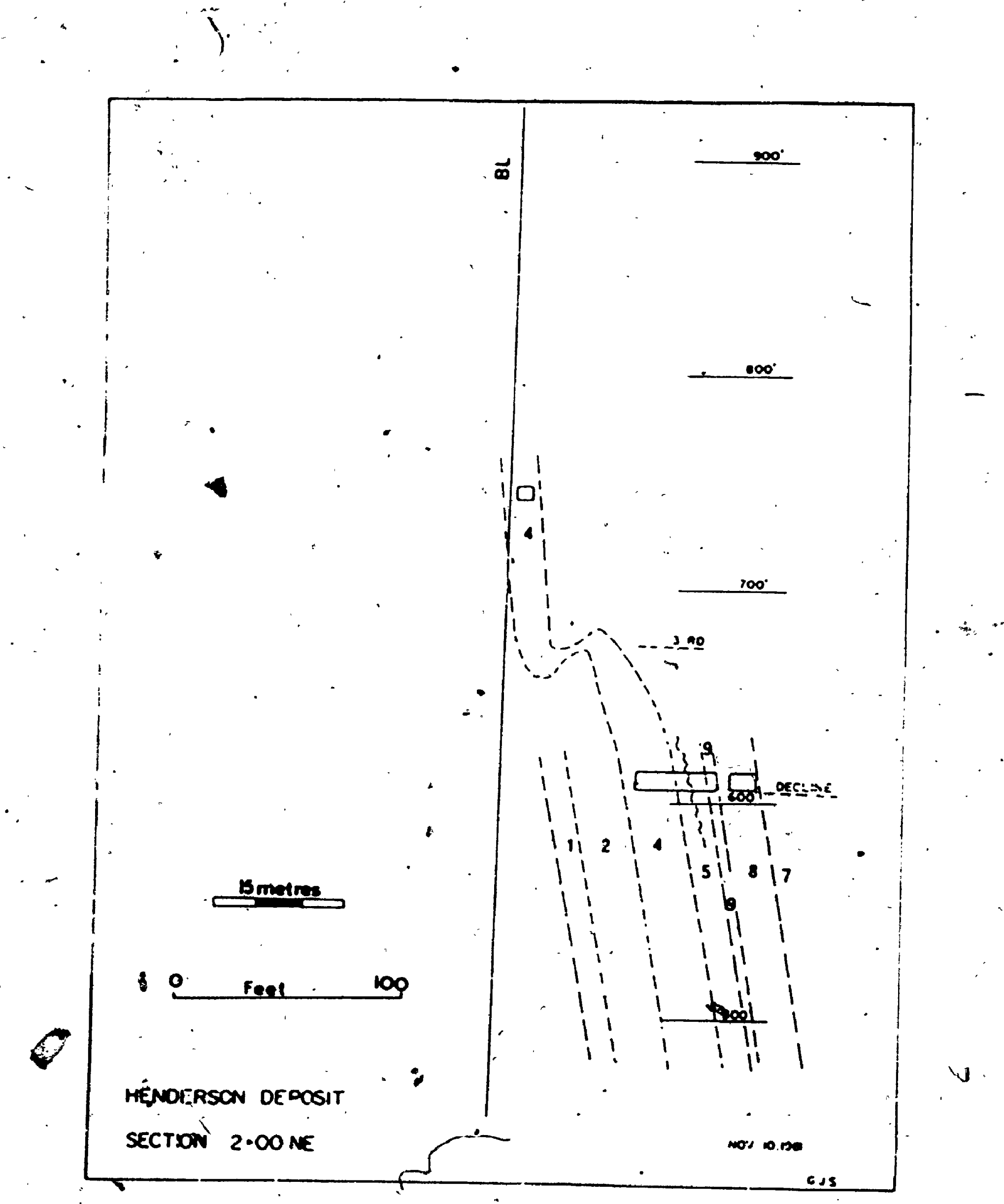





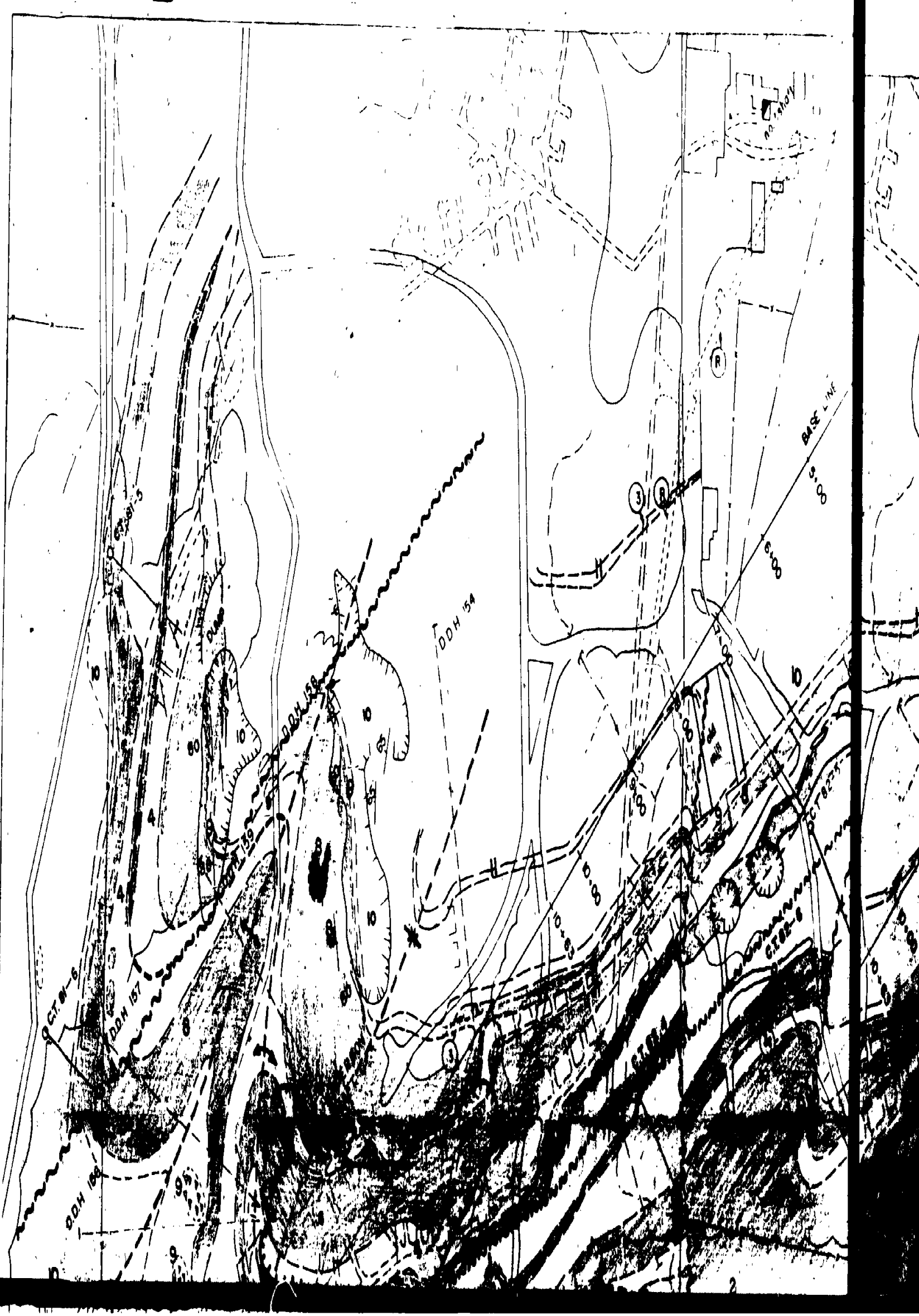





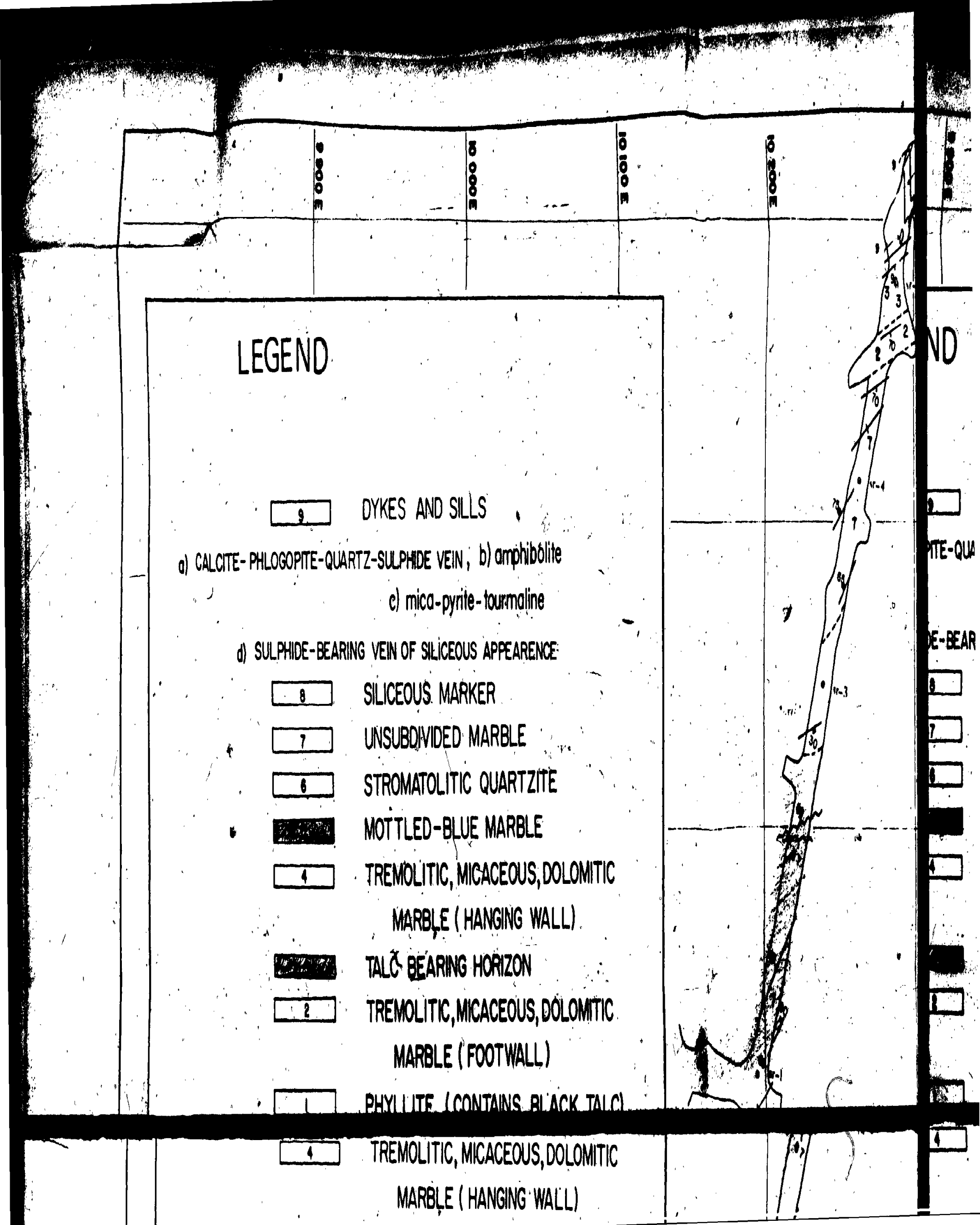




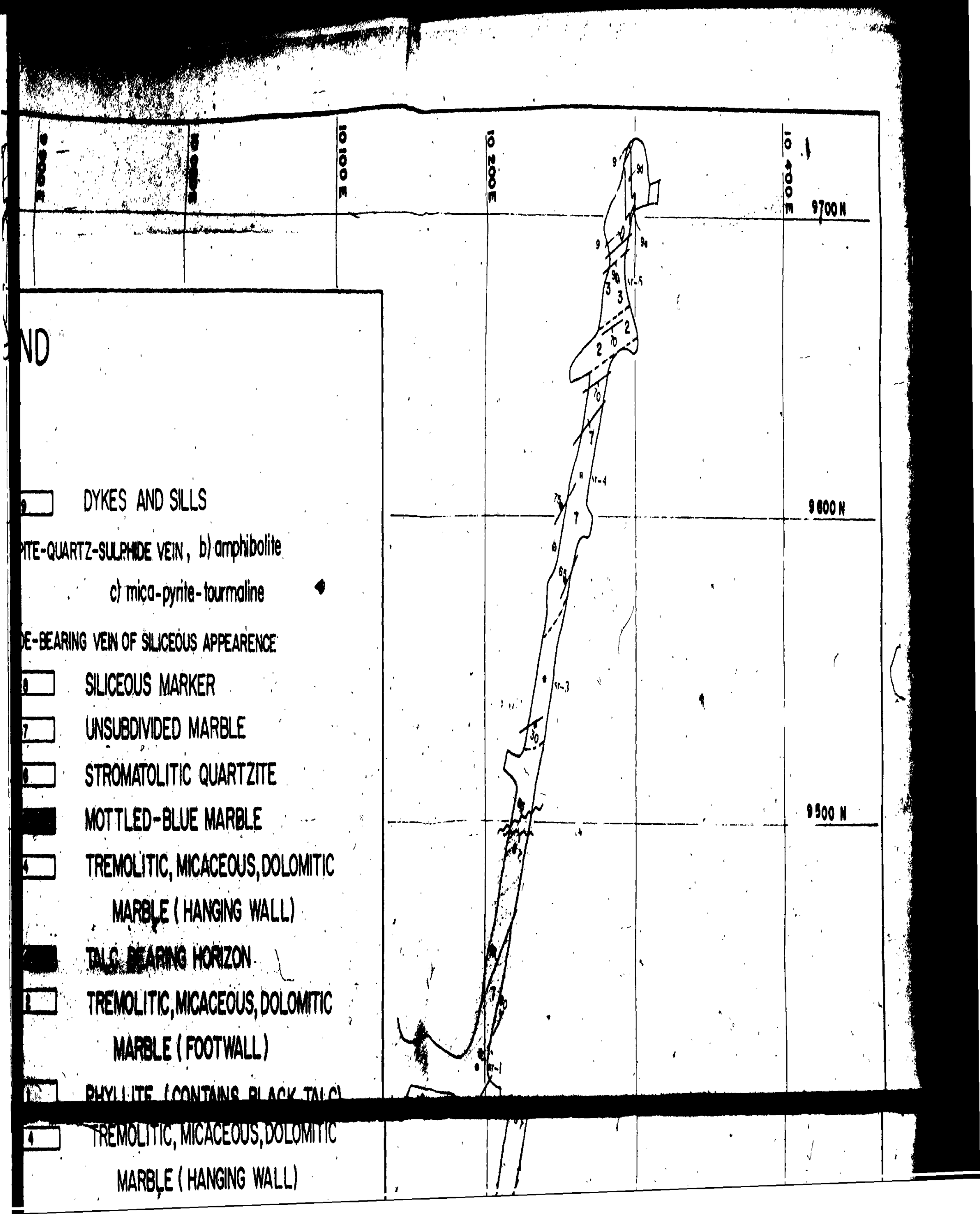




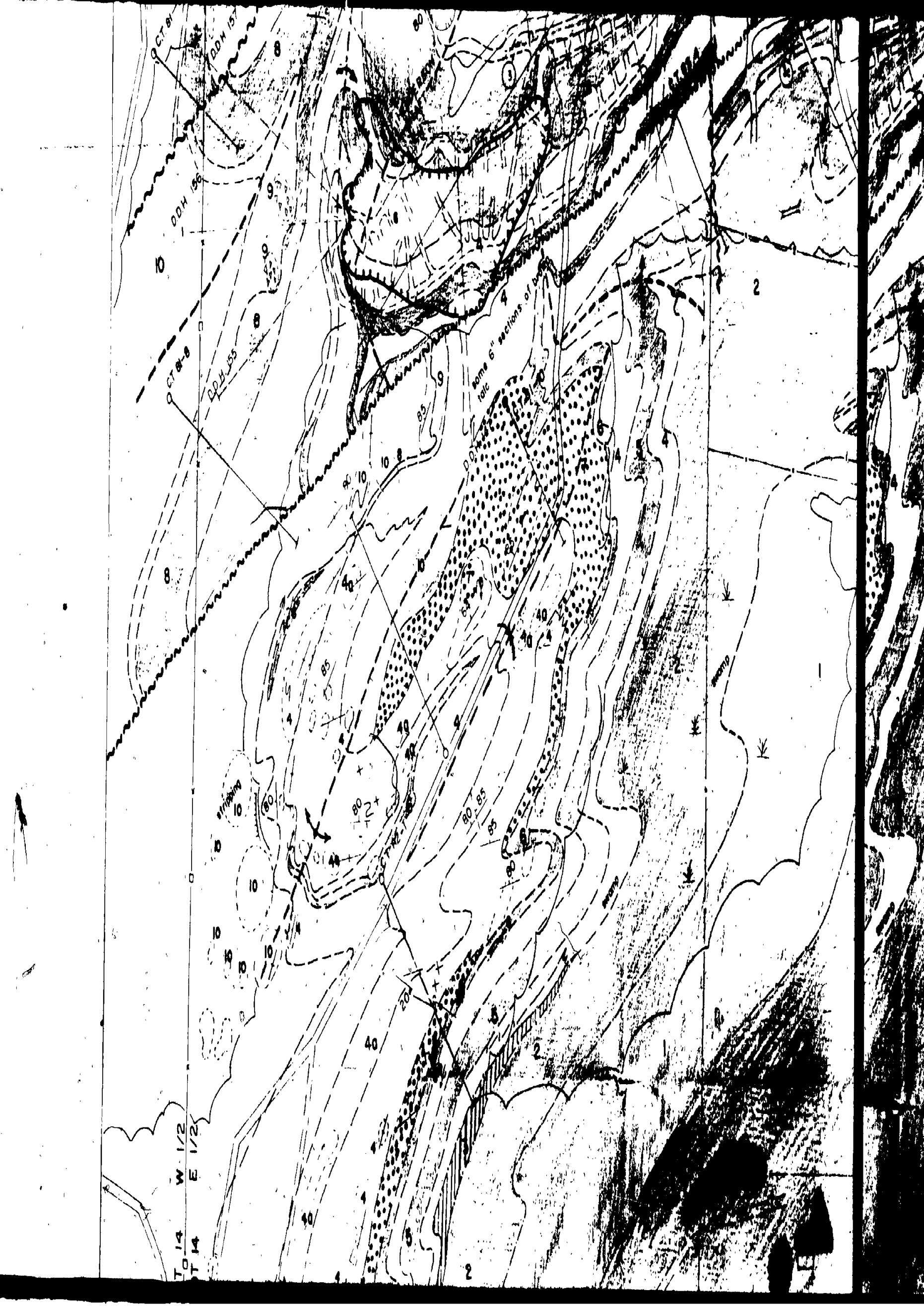





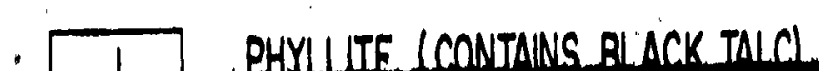

10

4 TREMOLTTC, MCACEOUS,DOLOMTIC MARBLE ( HANGNG WALL)

3 TALC BEARNG HOAIZON

2 TREMOLITC,MCACEOUS,DOLOMTIC MARBLE (FOOTWALL)

4

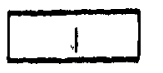

PHYLLITE (CONTANS BLACK TALC)

GEOLOGICAL CONTACTS ATTITUDE OF LAEERNG

FAULTS, SHEARS (defined, ossumed) SURVEY STATION 。

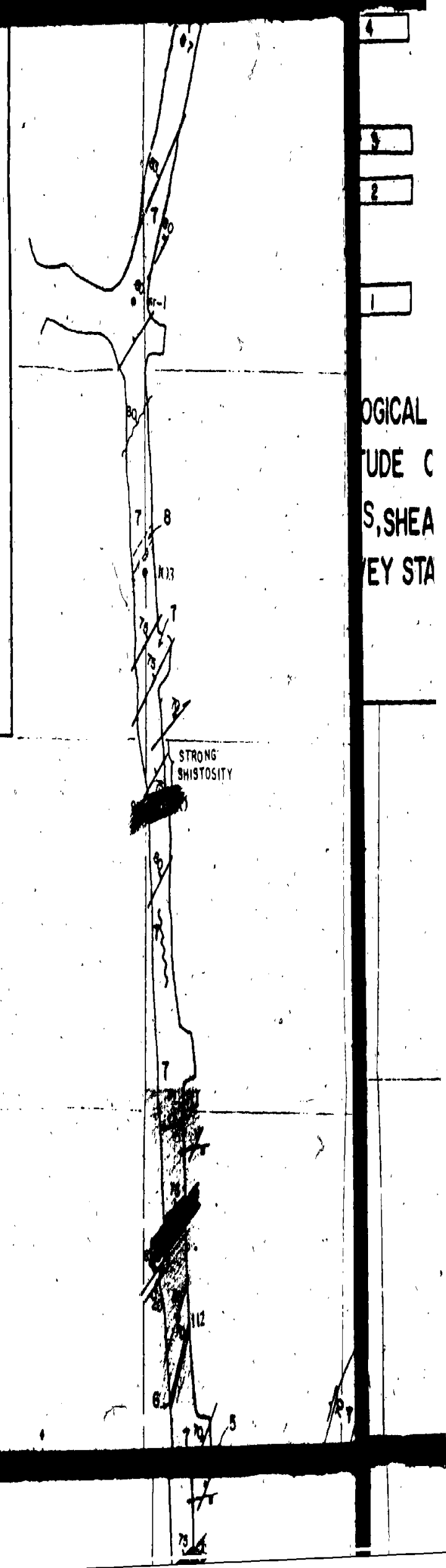


-1
0

2 i

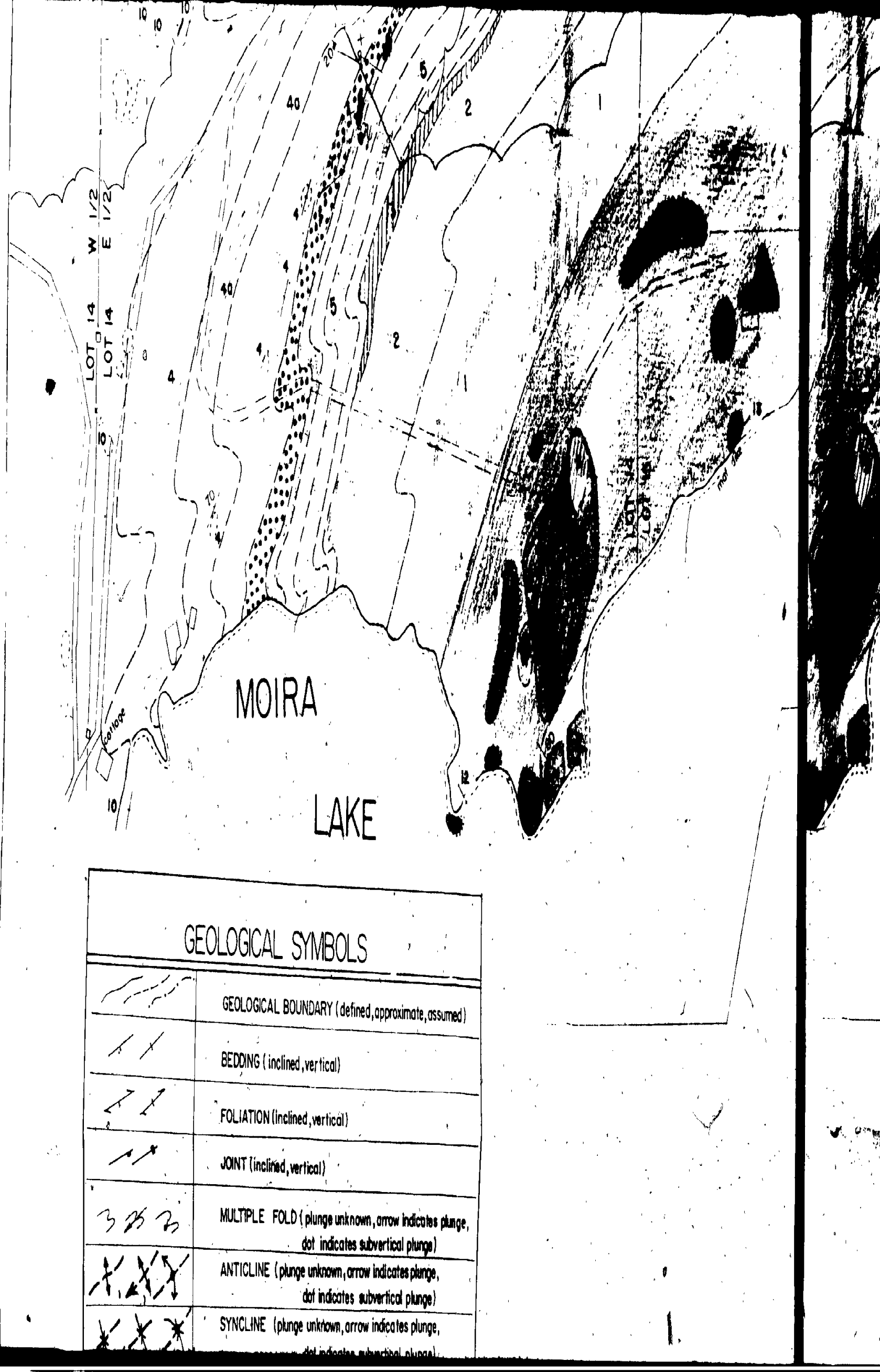




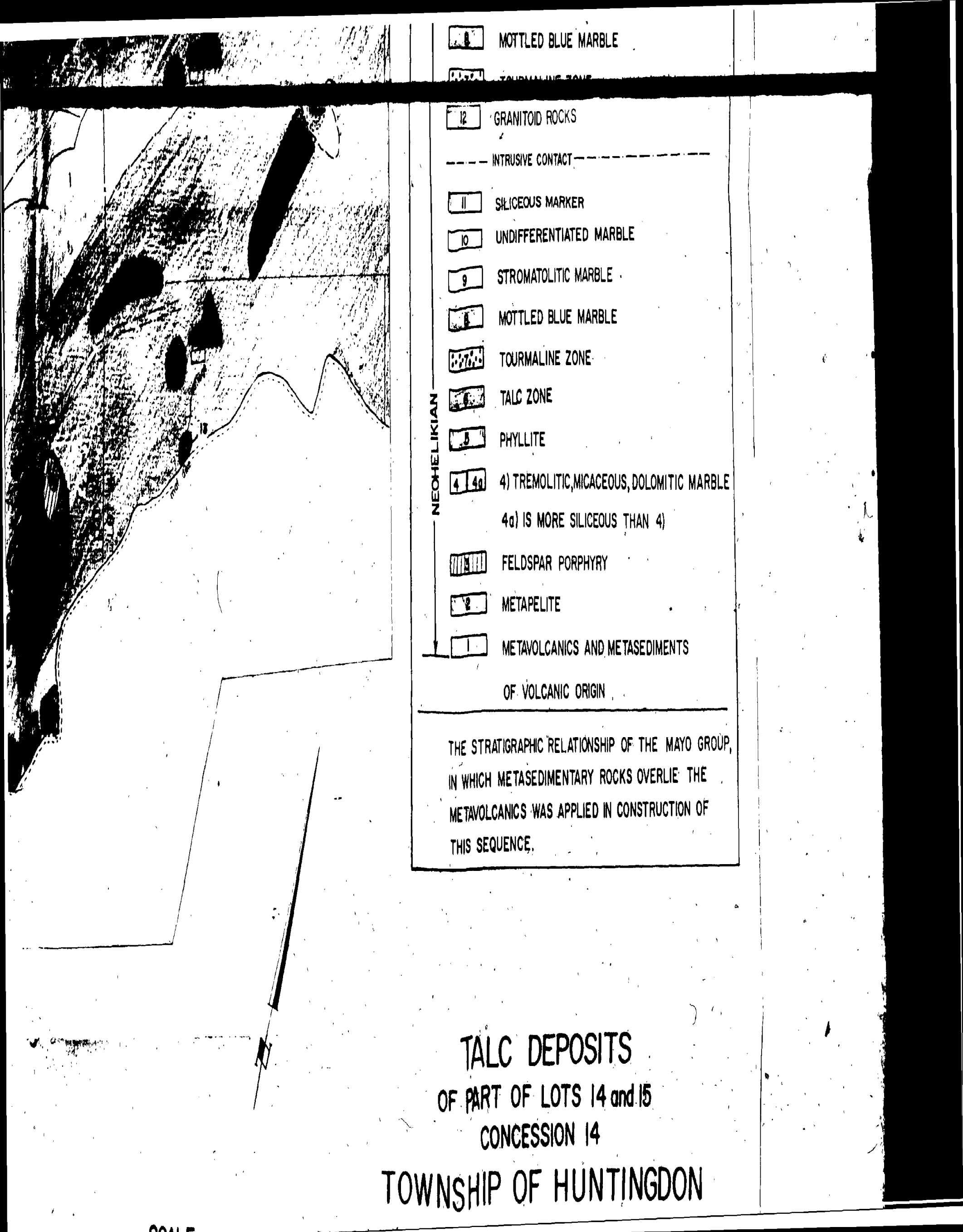




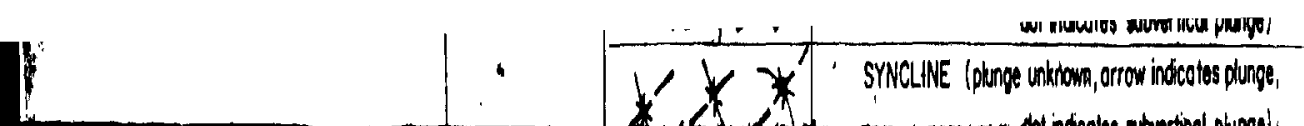

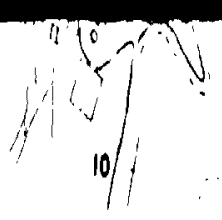

LAKE

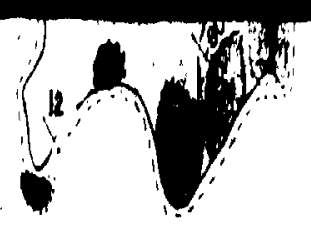

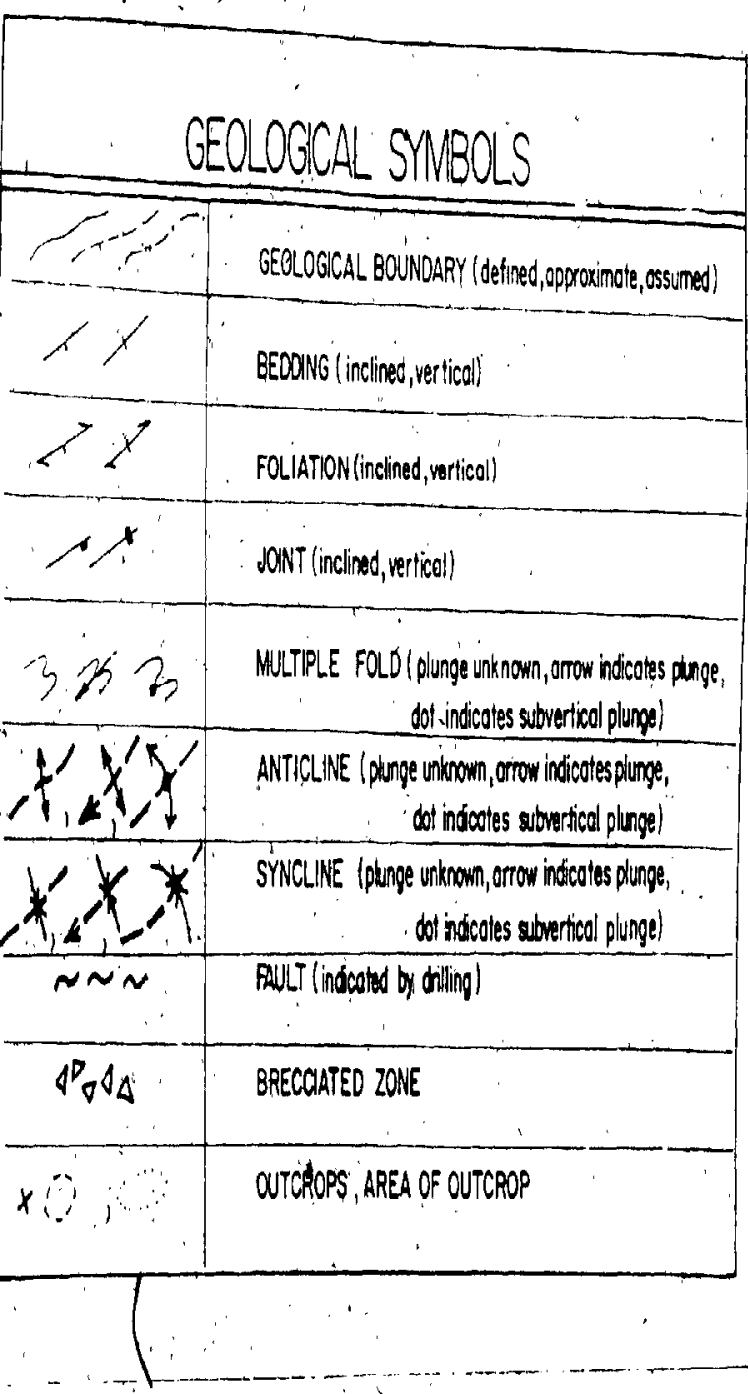
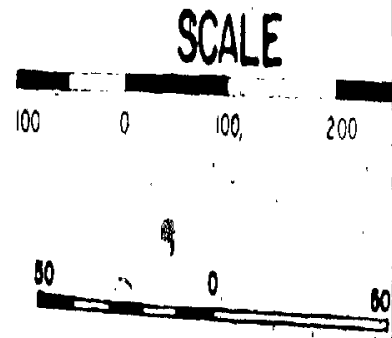

. 


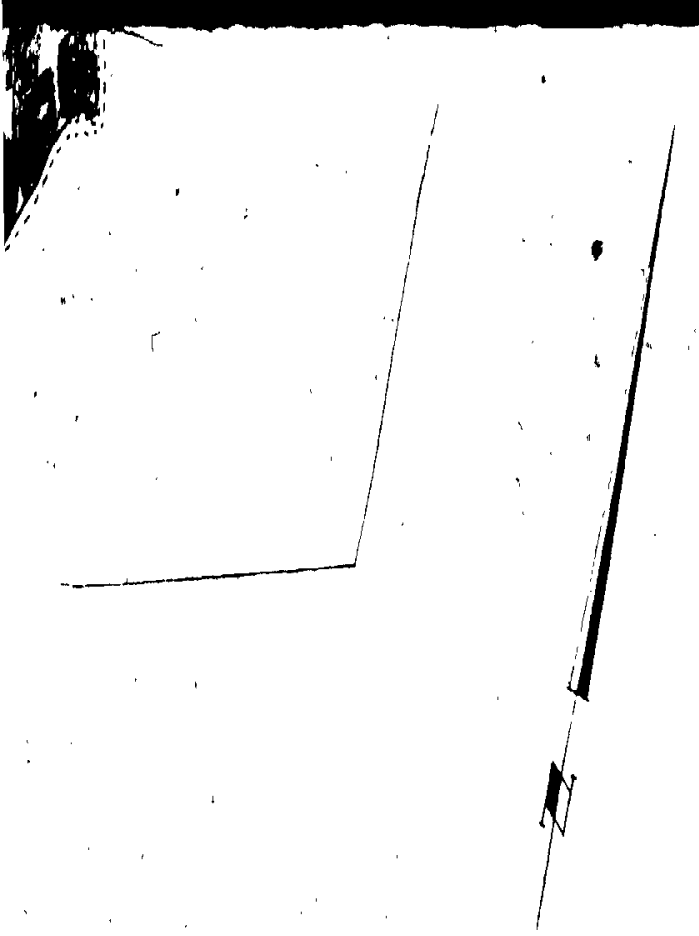

1
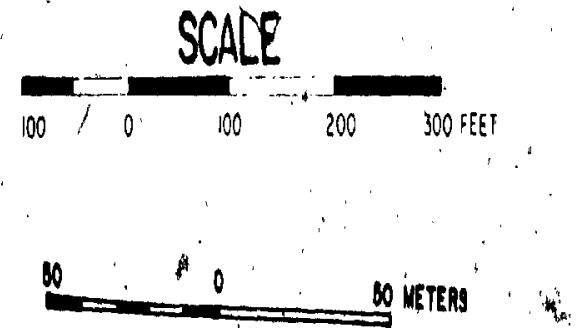

THE STRATGGRAPHIC RELATIONSHIP OF THE MAYO GROUP, IN WHICH METASEOIMENTARY ROCKS OVERLIE THE METAVOLCANICS WAS APPLIED IN CONSTRUCTION OF THIS SEOUENCE.

\section{TALC DEPOSITS. \\ OF PRTT OF LOTS 14 and 15 CONCESSION 14} TOWNSHP OF HUNTINGDON COUNTY OF HASTINGS

\section{fig.6}




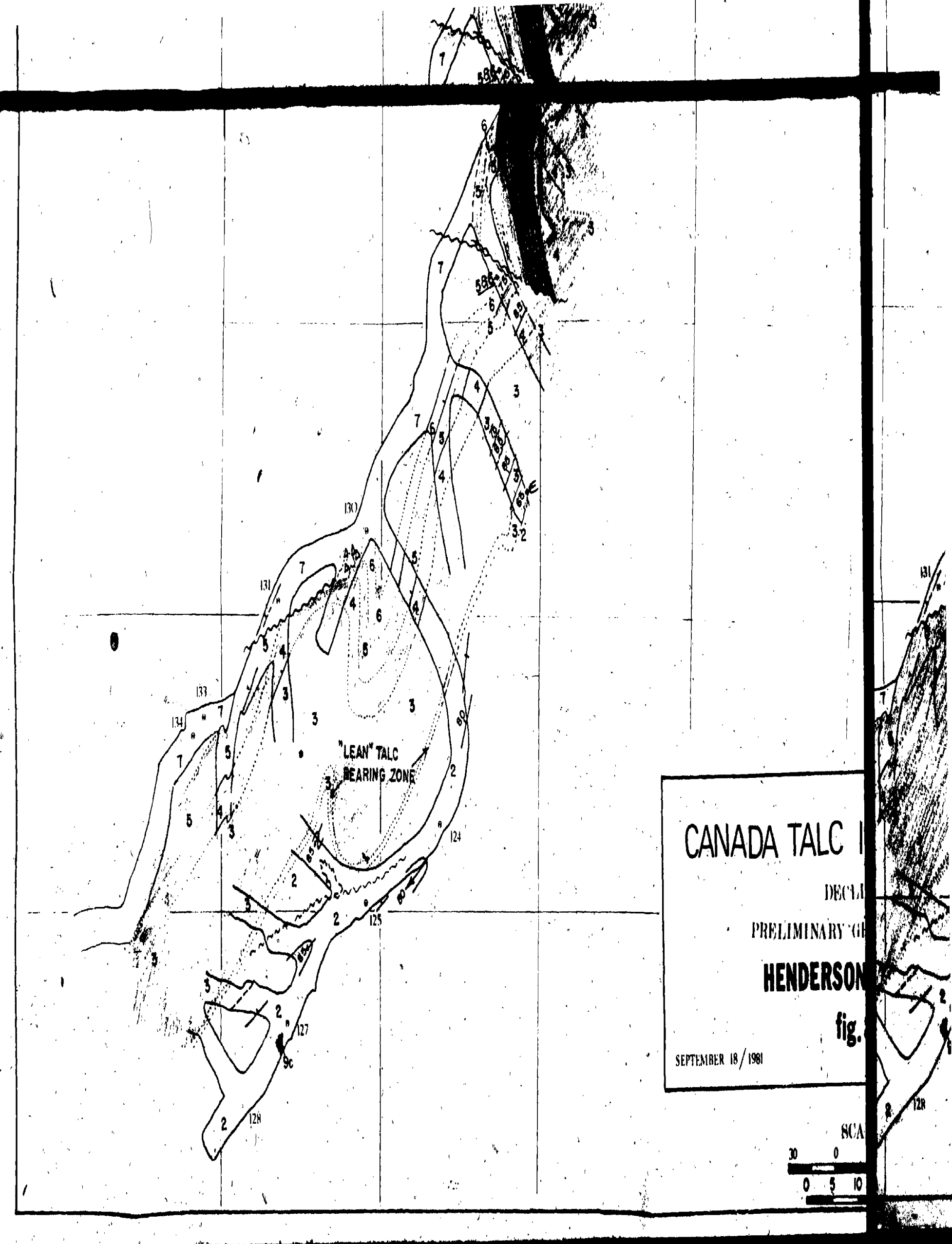


ananar

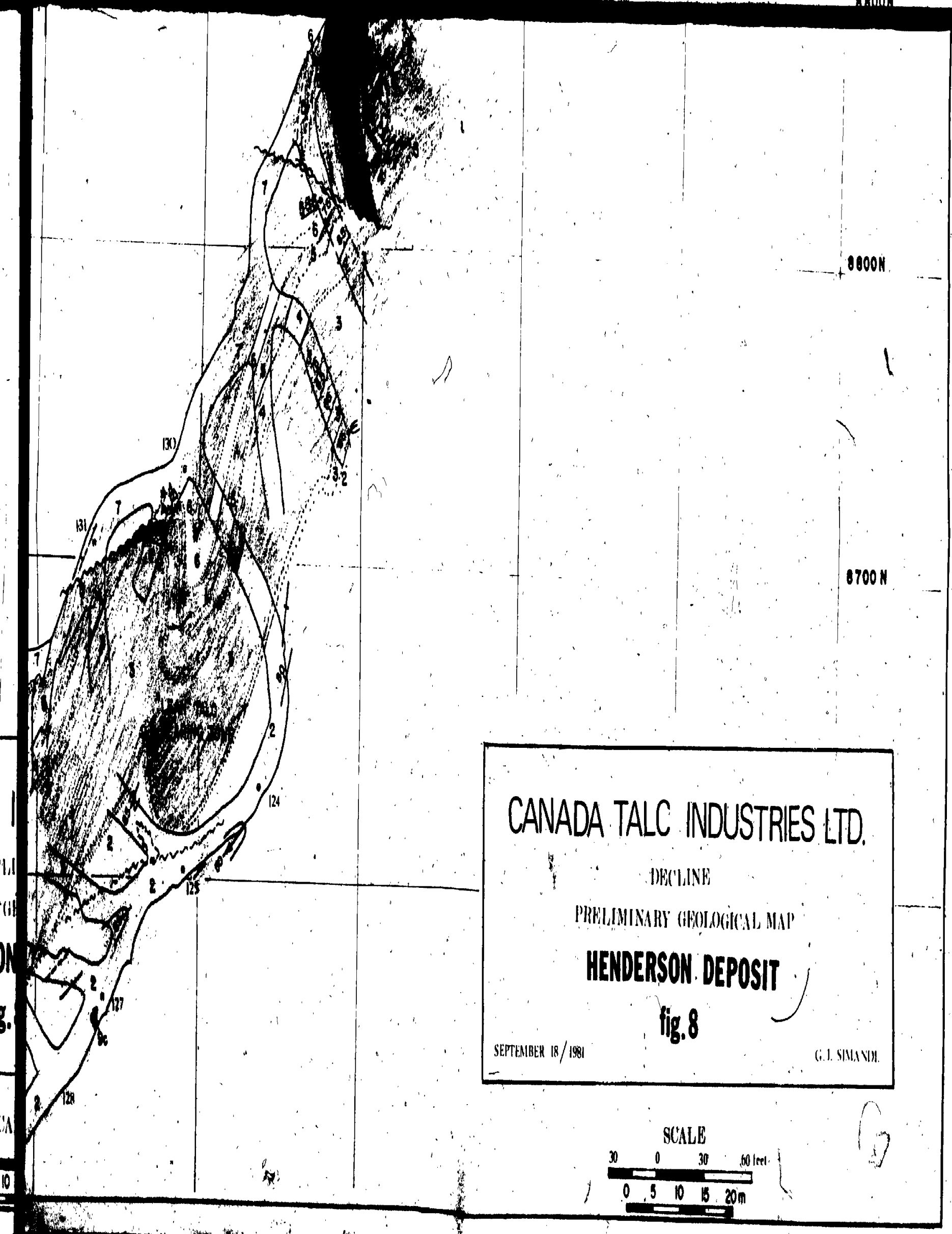


LEGEND

DYM DES AND SILLS

a) CALCITE-PHLOCOPITE-OUARTZ-SULPAIDE VEN

b) AMPHBOLTE CI mico-pynile-fourmaline

d) SUPHIDE-BEARNG VEN OF SLLCEOUS APPEARANCE

SILCEOUS MARKER

1 WSUBOVIDED MARBLE

I. STROMATOLITIC QUARTZITE

TOTTLED-BLLE MARBLE

TREMOLITIC, MICACEOUS, DOLOMITIC MARBLE ( HANGNG WALL).'

TALC BEARING HORIZON

TREMOLITIC,MICACEOUS, DOLOMTIC MARBLE (FOOTWALL)

PHYLLITE I CONTANS BLACK TALC

GEOOOCCAL CONACT IDEFNEO, ASSUIEOT ....

ATTTUDE OF LARERNG $>$, T

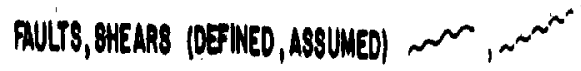

SURVEY STATION OMS

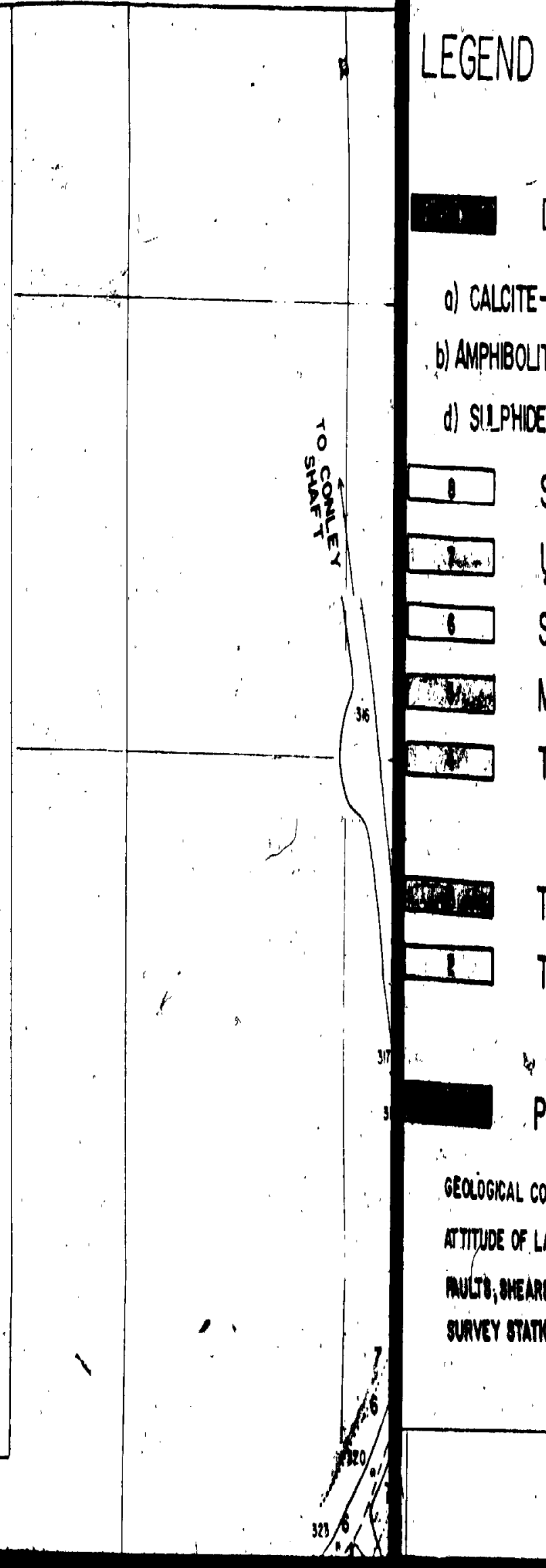




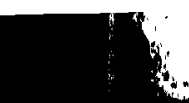

$y^{\prime}:$
LEGEND

$\therefore$ DYKES AND SILLS

a) CALCITE-PHLOGOPTE-OUARTZ-SULPHIDE VEN

b) AMPABBOLTE d) mico-pynie- fourmoline

d) SLIPHIOE-BEARNG VEN OF SLLICEOUS APPEARANCE

$\square$ SLILEOUS MARKER

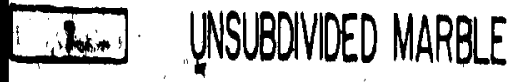

1 STROMATOLITIC QUARTZITE

DUT MOTLED-BLUE MARBLE

TPE TREOLTTC, MCACEOUS, DOLOMTCC MAPBQEL (HANGNG WALLL)

WWTE TALC BEARMG HORZZON

1 TPENOLITC, MILACEOUS, OOLONTTC

A. MARBEE (POOTWALL) PHYLLTE ICONTANS BLACK TALC

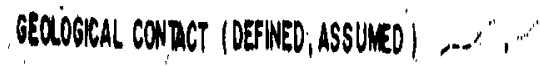

ATITUOE OF LAVRNG $x, x$

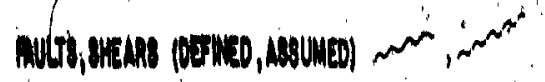

survey sinoth or

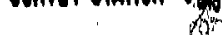

\section{$\uparrow$}

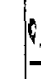

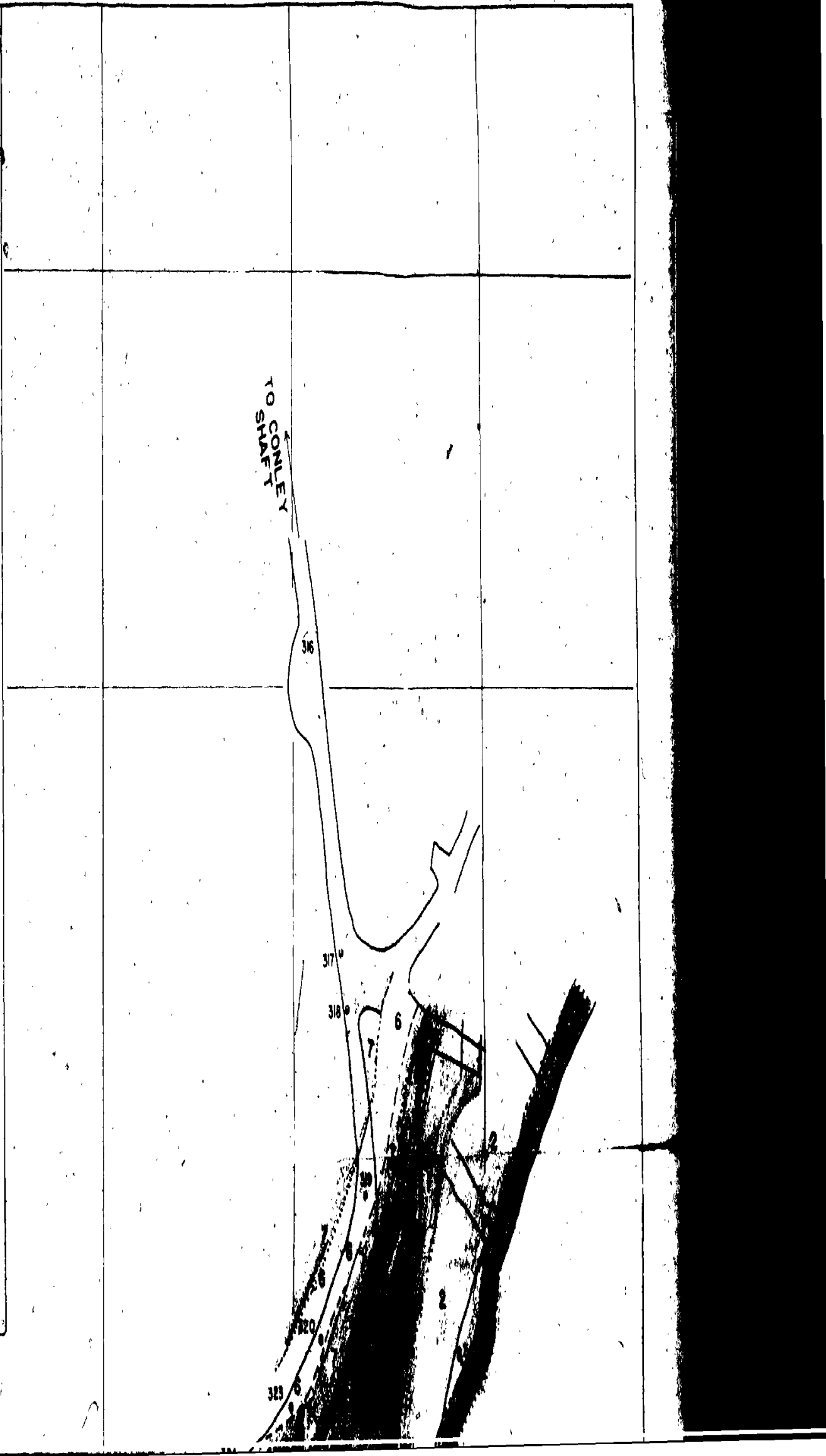




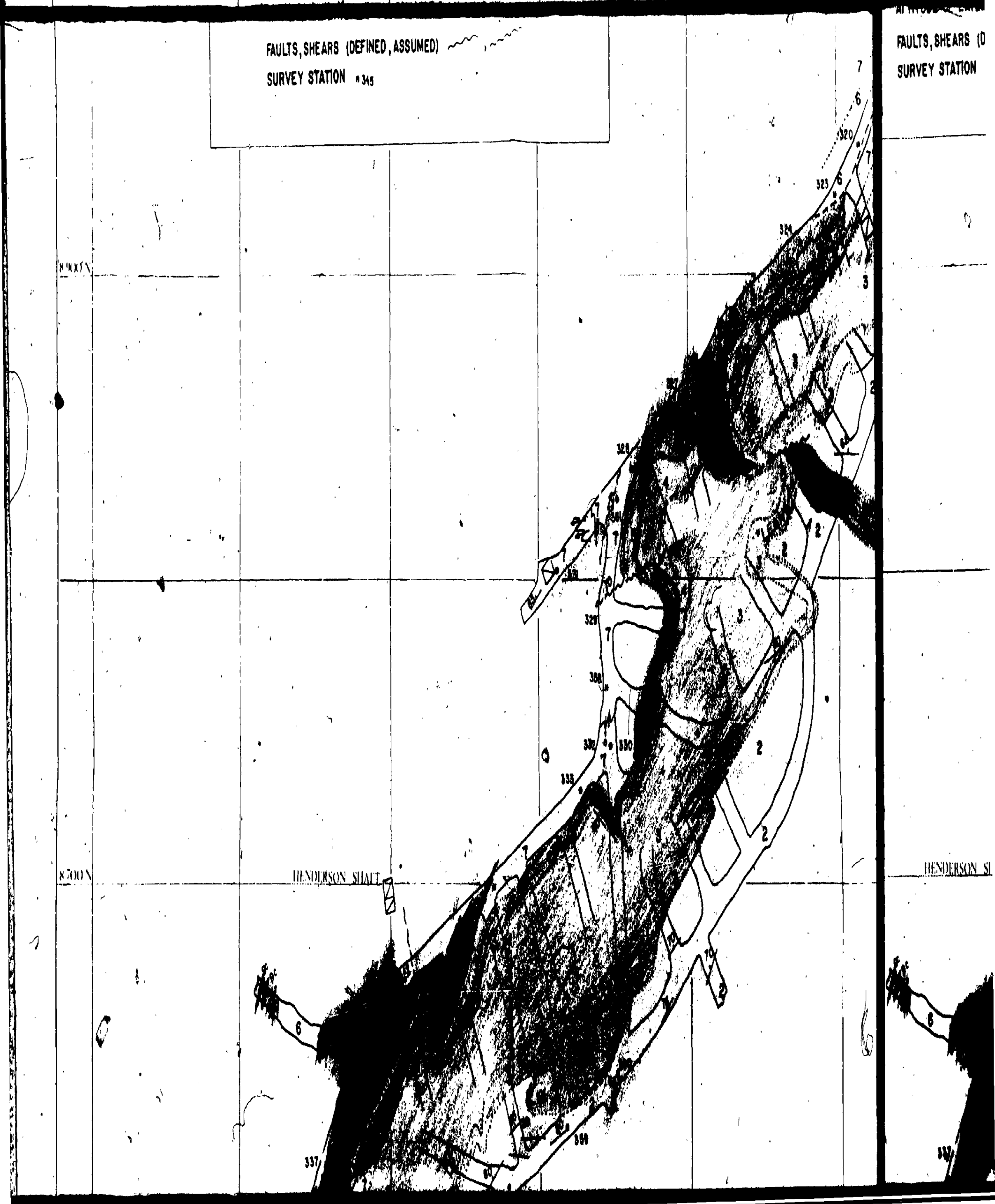








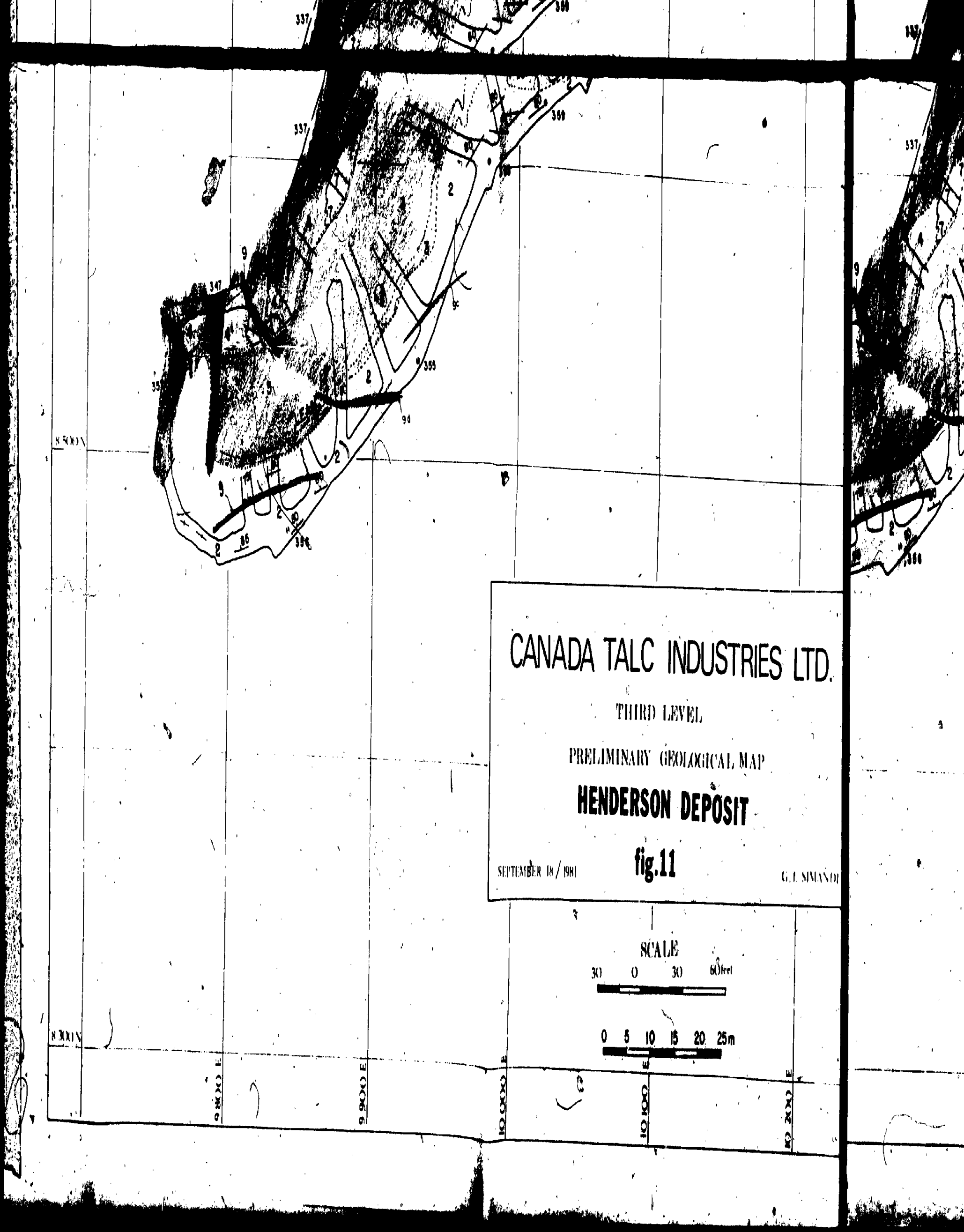



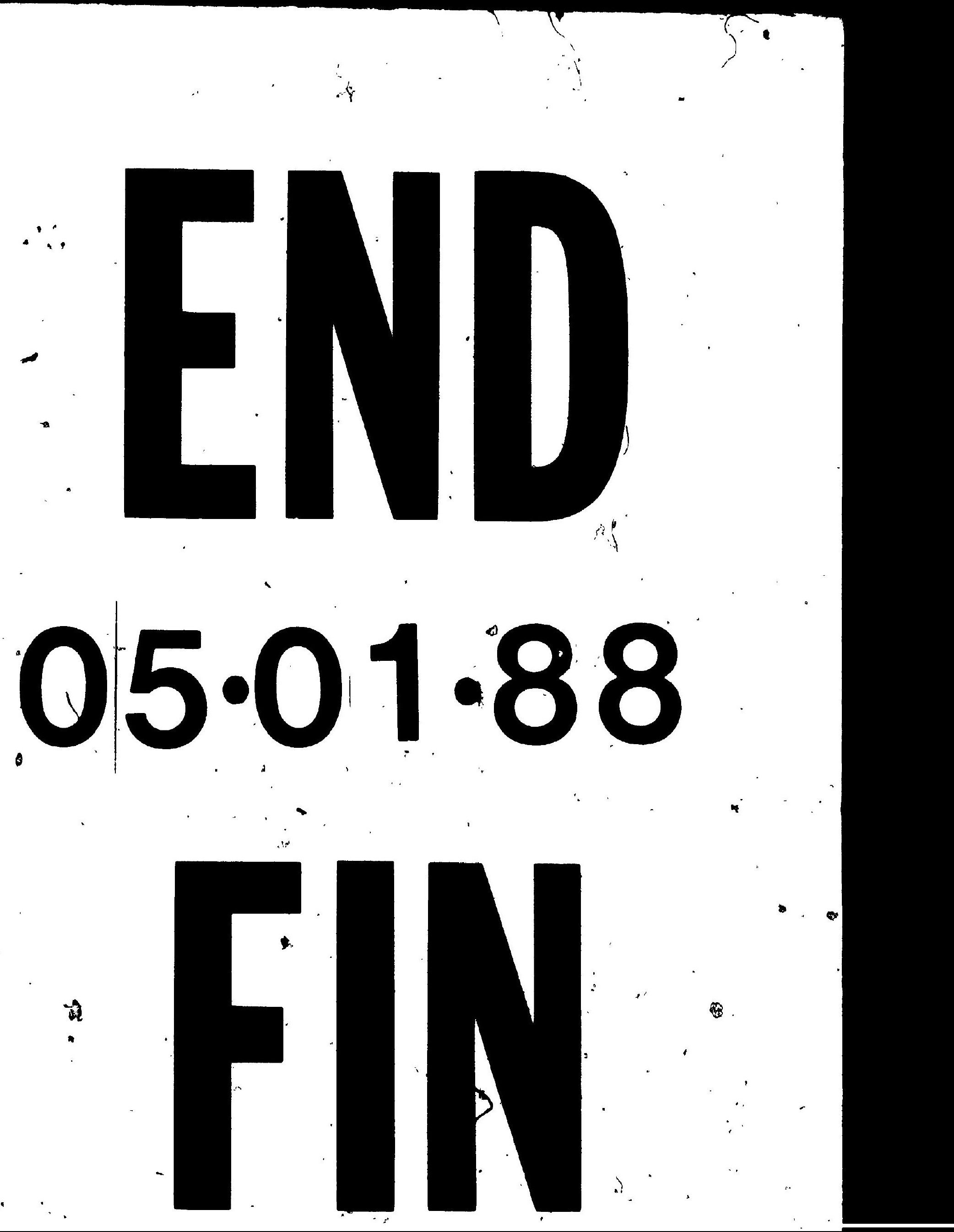

